\title{
'SB
}

356

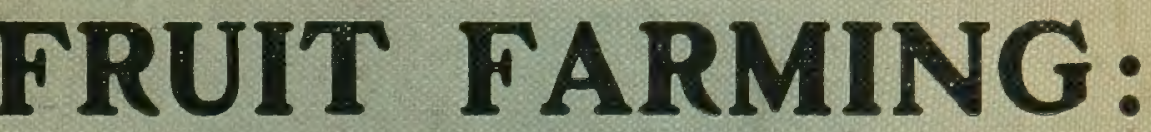

\section{PRACTICAL AND SCIENTIFIC}

FOR COMMER CIAL FRUIT GROWERS

AND OTHERS.

\section{By \\ CECIL H. HOOPER \\ M.R.A.C., F.S.I.}

SECOND EDITION.

WITH SPECIAL ARTICLES BY MANY EXPERTS.

Fully Illustrated.

THE LOCKWOOD PRESS,

1, Mitre Court, Fleet Street, London, E.C. 


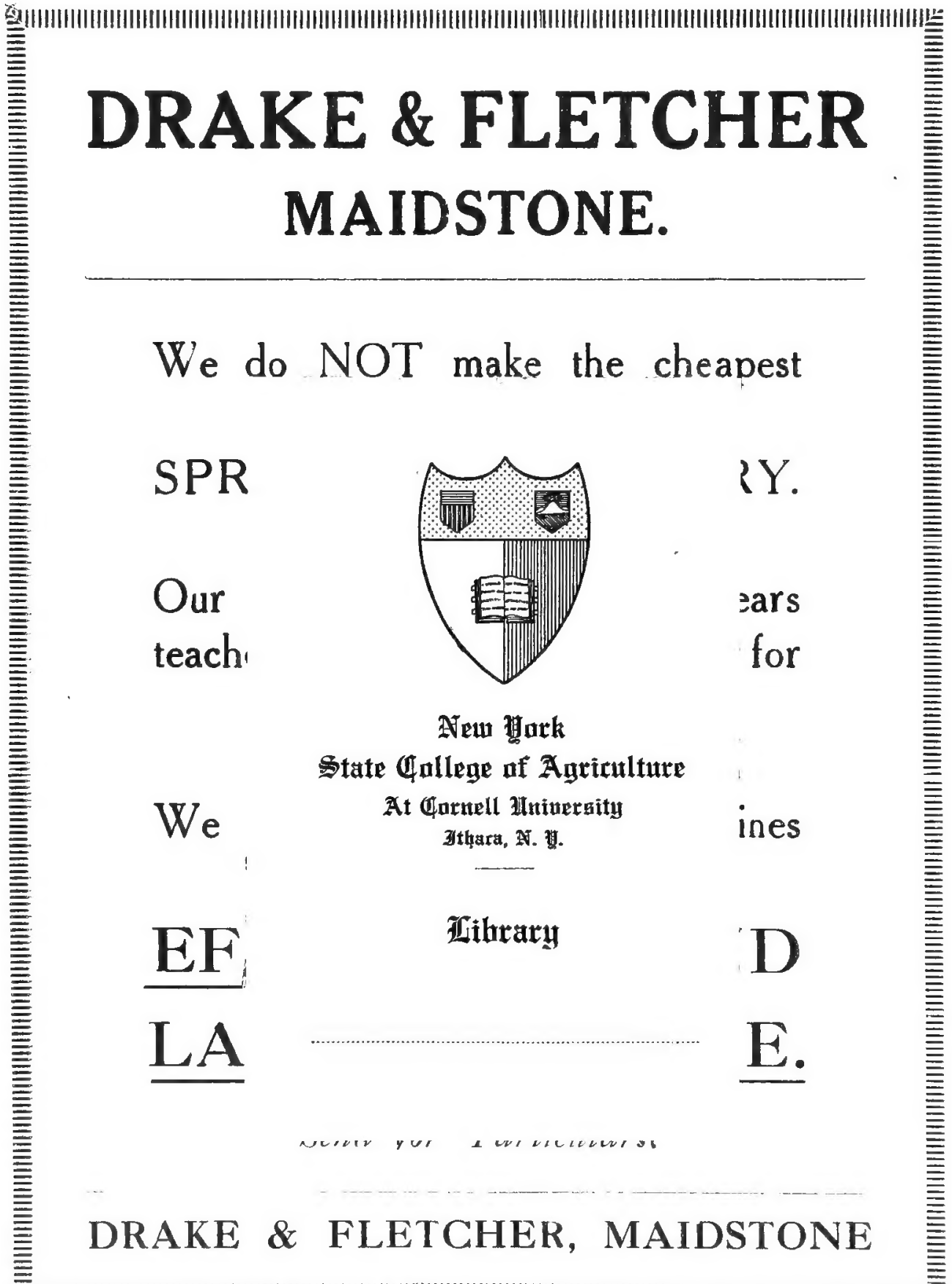




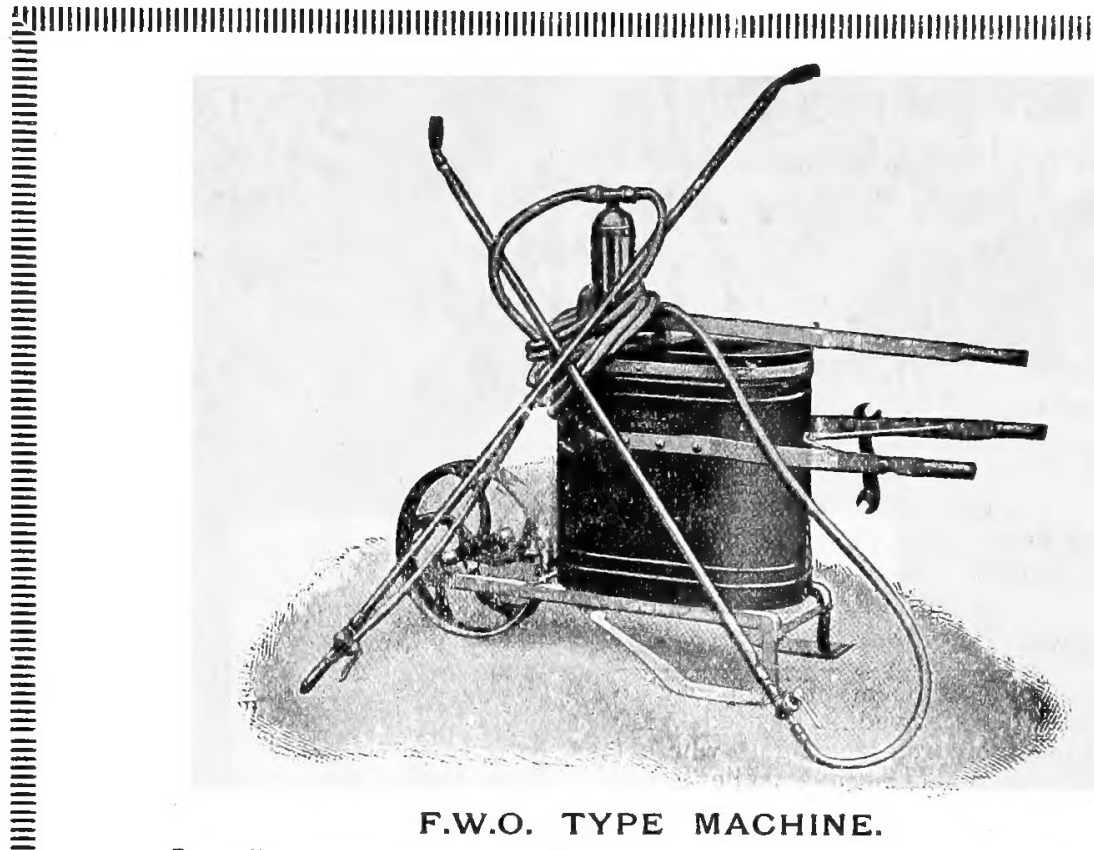

Specially narrow for use in Bush Fruit. Complete with two $20 \mathrm{ft}$. hoses, bamboo or brass branch pipes, taps and nozzles. 18 gallon capacity.

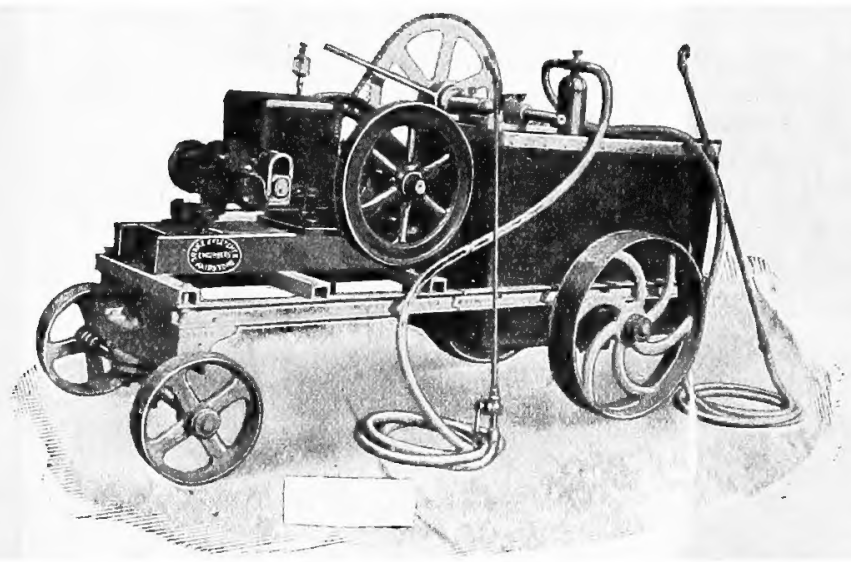

S.P.S. TYPE POWER MACHINE.

Our Smailest Power Machine, compiete with hoses and Fittings. Delivered ready for work. 60 gallon capacity. £85.

\section{DRAKE \& FLETCHER, MAIDSTONE}


C

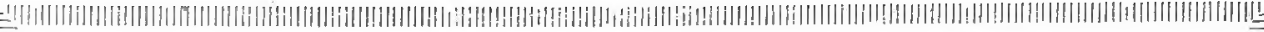

\section{"STEROLE not only destroys insects and fungi, but also gives extra vitality to the soil."}

\section{By simply spreading}

STEROLE powder evenly on the ground in proper season you can destroy all insects hibernating or sheltering in the soil, and so save serious attacks of these pests later. Winter and March moths, raspberry and apple weevils, sawflies, woolly aphis (root form), pear midge, elc.

Sterole supersedes grease bands because it is more effective and catches greater variety of insects, whilst its effect on tree growth is remarkable.

"In my opinion it seems unnecessary to grease-band where STERole is used. My trees are absolutely free from moth where I used it, and I have also got an excellent crop where I had none last year owing to its efficacy in deatroying the larvæ of winter moth. Please send four times the quantity I had last year."

-Badsey.

Sterole also destroys wireworm, leather jackets, cockchafer grub, slugs, pea weevil, eelworm and also fungus diseases attacking plant roots. Full particulars

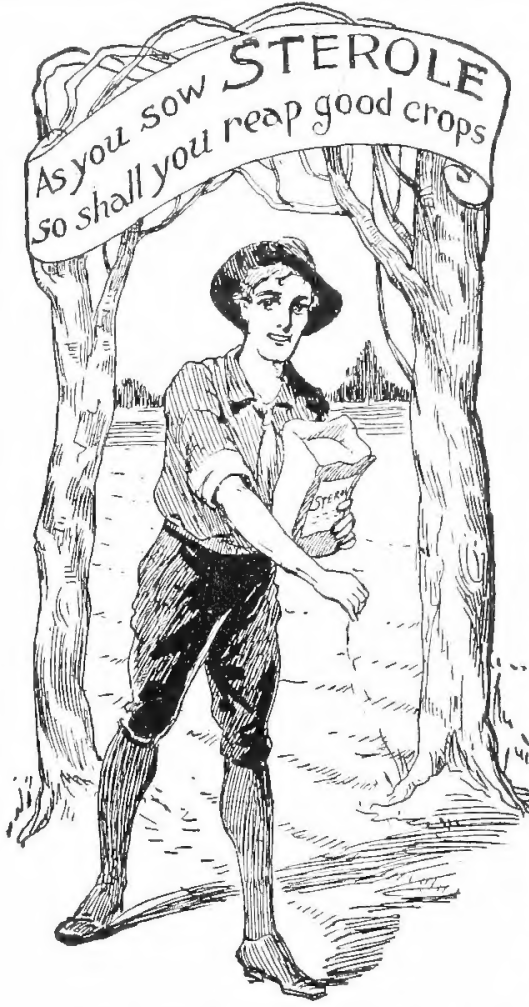
gladly sent upon request. I also manufacture GREEN SULPHUR, A.S. WINTER WASH, CALSO DRY SPRAY, POWDER INSECTICIDES, ARSENATE OF LEAD, NICOTINE SOAP, SOFT SOAP, DYPHENIN and LIGNOL.

\section{Have the best ignore the rest}

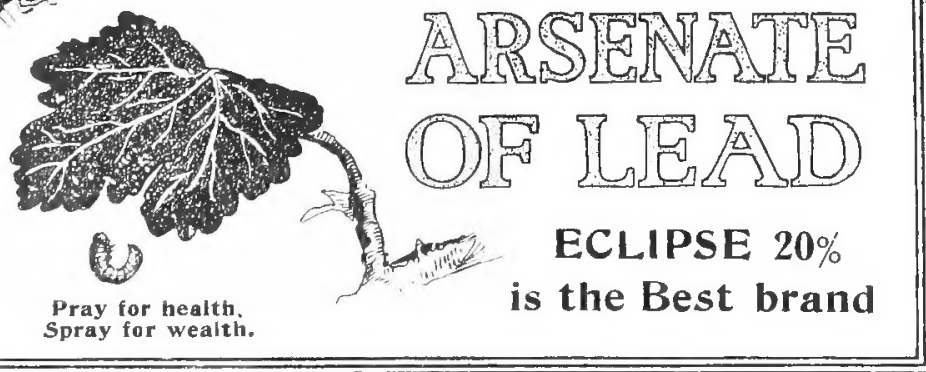

E.R.BUGGE

F.G.S.

Eclipse Works,

WESTCOMBE

HILL,

LONDON,

S.E.3 


\section{FRUIT FARMING:}

\section{PRACTICAL AND SCIENTIFIC}

FOR COMMERCIAL FRUIT GROWERS

AND OTHERS.

By

\section{CECIL H. HOOPER, F.S.I.}

Member of the Royal Agricultural College, Cirencester;

Life Fellow Highland and Agricultural Society of Scotland (by examination);

Silver Medallist, Royal Agricult aral Society of Ireland;

Member of the Scientific Committee, Royal Horticultural Society.

LAND AGENT, SURVEYOR \& TENANT-RIGHT VALUER.

$$
\begin{aligned}
& \text { WITH SPECIAL ARTICLES } \\
& B Y \text { MANY AUIHORITIES. }
\end{aligned}
$$

\section{SECOND EDITION}

Revised, extended and fully illustrated.

THE LOCKWOOD PRESS,

(HARVEY H. MASON).

i, Mitre Court, Fleet Street, London, E.C. 


\section{DATE DUE}

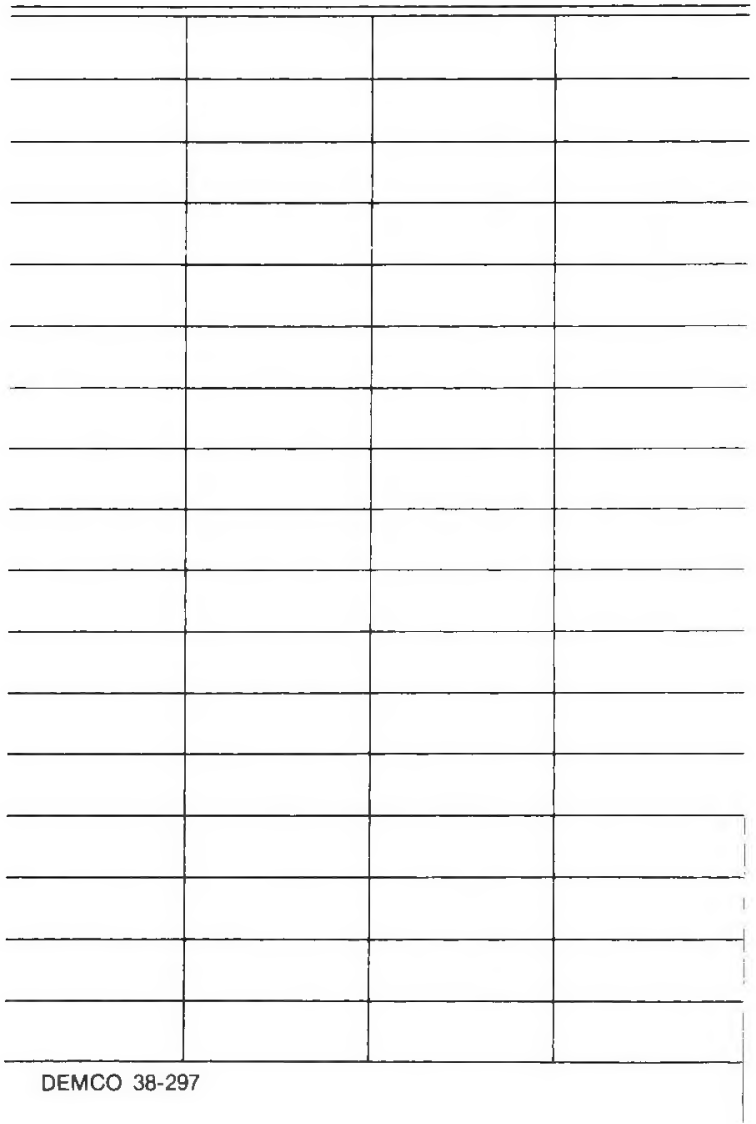

SB 356. 478

Fruit farming:practical and scientific,

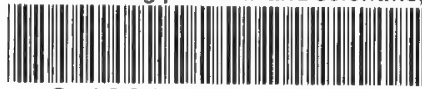

31924000238869 


\section{W.: Duncan Rucker ESons \\ HORTICULTURAL BUILDERS AND HEATING ENGINEERS.}

We are SPECIALISTS in the construction of Growers' Glasshouses $:::$ and our long and varied experience is at your service. $:: \quad:$ TOMATO AND CUCUMBER HOUSES CARNATION HOUSES AND VINERIES $6 \mathrm{ft}$. by $4 \mathrm{ft}$. PITLIGHTS ALWAYS IN STOCK Clients waited upon in any part of the Country, and advice given as to the best method of building

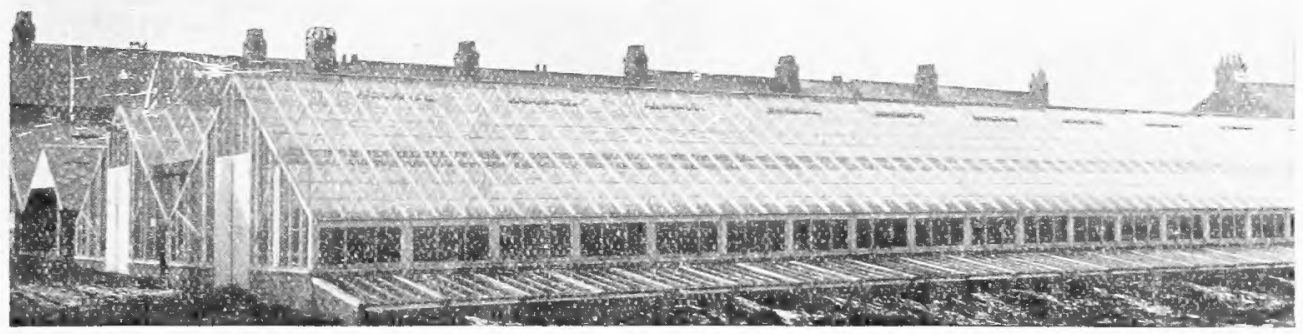

View of Two Tomato and Chrysanthemum Houses, each $175 \mathrm{ft}$. long by $25 \mathrm{ft}$. wide, erected at Bletchley, Bucks.

Having Special Machinery and the best facilities for handling, we can exectite the Largest Order with the Greatest Speed.

GLASSHOUSES ERECTED, GLAZED AND PAINTED COMPLETE, or Prepared Material only supplied, all to true Sections and Bevels.

TIMBER can be supplied Cut and Fitted ready for easy erection IRONTORK, GLASS, PAINT : : Estimates Free.

HEATING APPARATLS fixed complete, on the most up-todate principles, or Materials only supplied.

OUR NEW ILLUSTRAFED CATALOGUE IS OF INSTRUCTIONAL VALUE TO THOSE CONTEMFLATING REBUILDING OLD HOUSES OR ERECTIN NEW ONES. POST FREE UPON REQUEST.

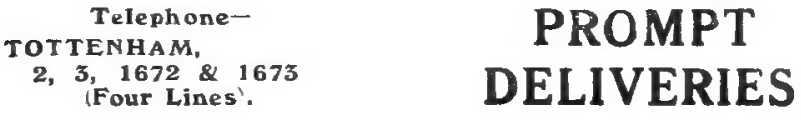

PROMPT Telegrams-

"HORTICOLE,

TOTCROSS, 


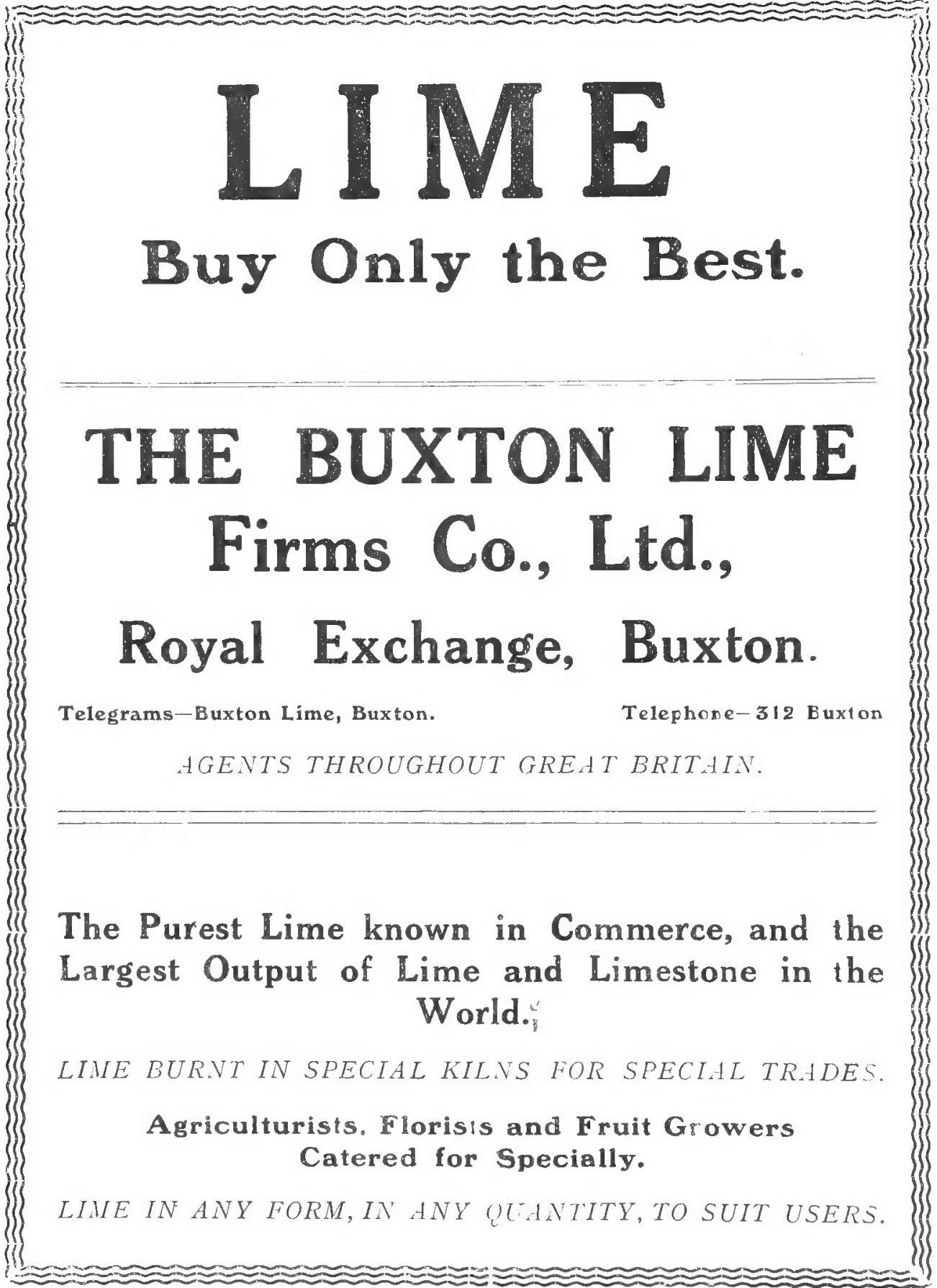




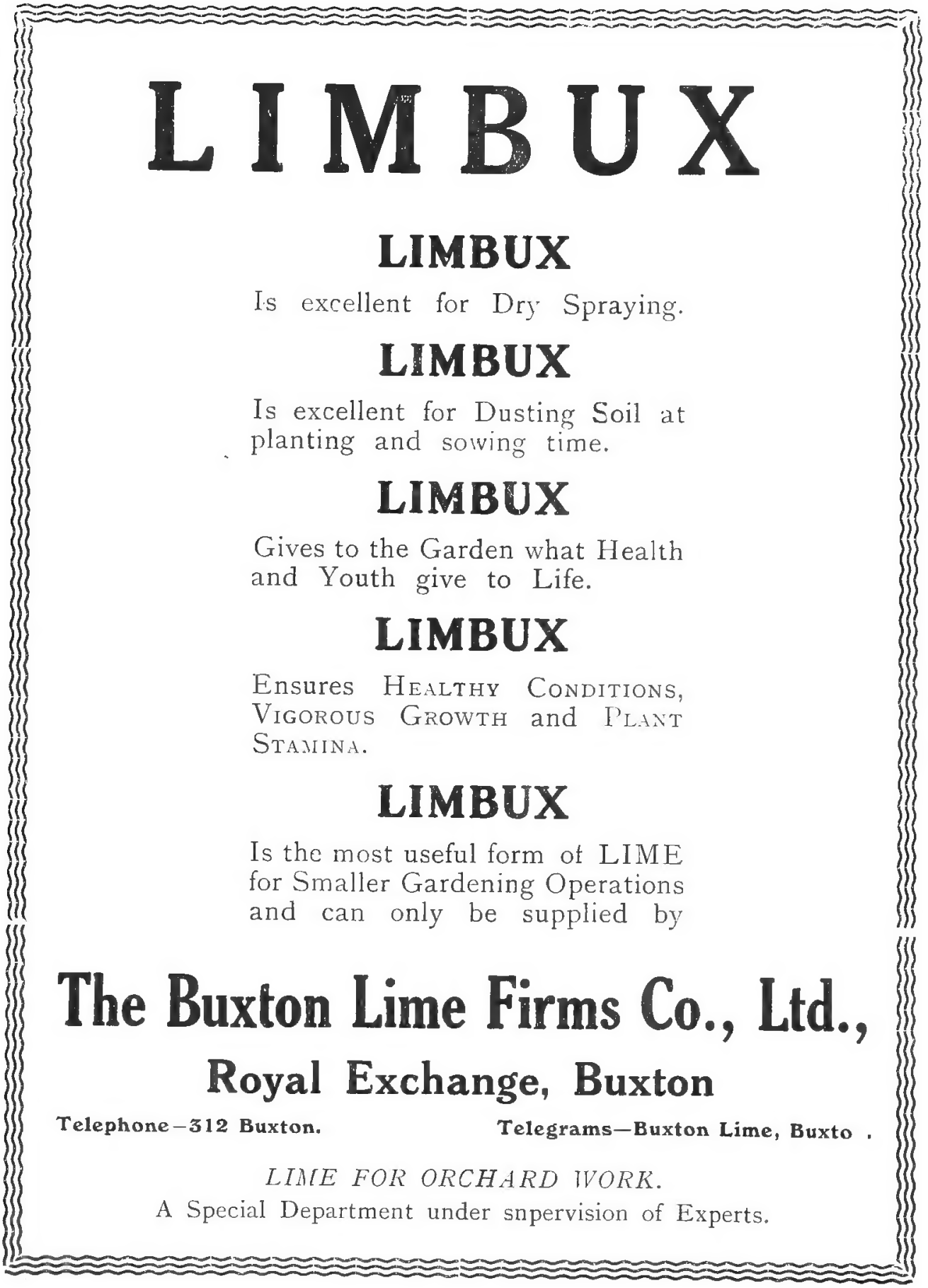




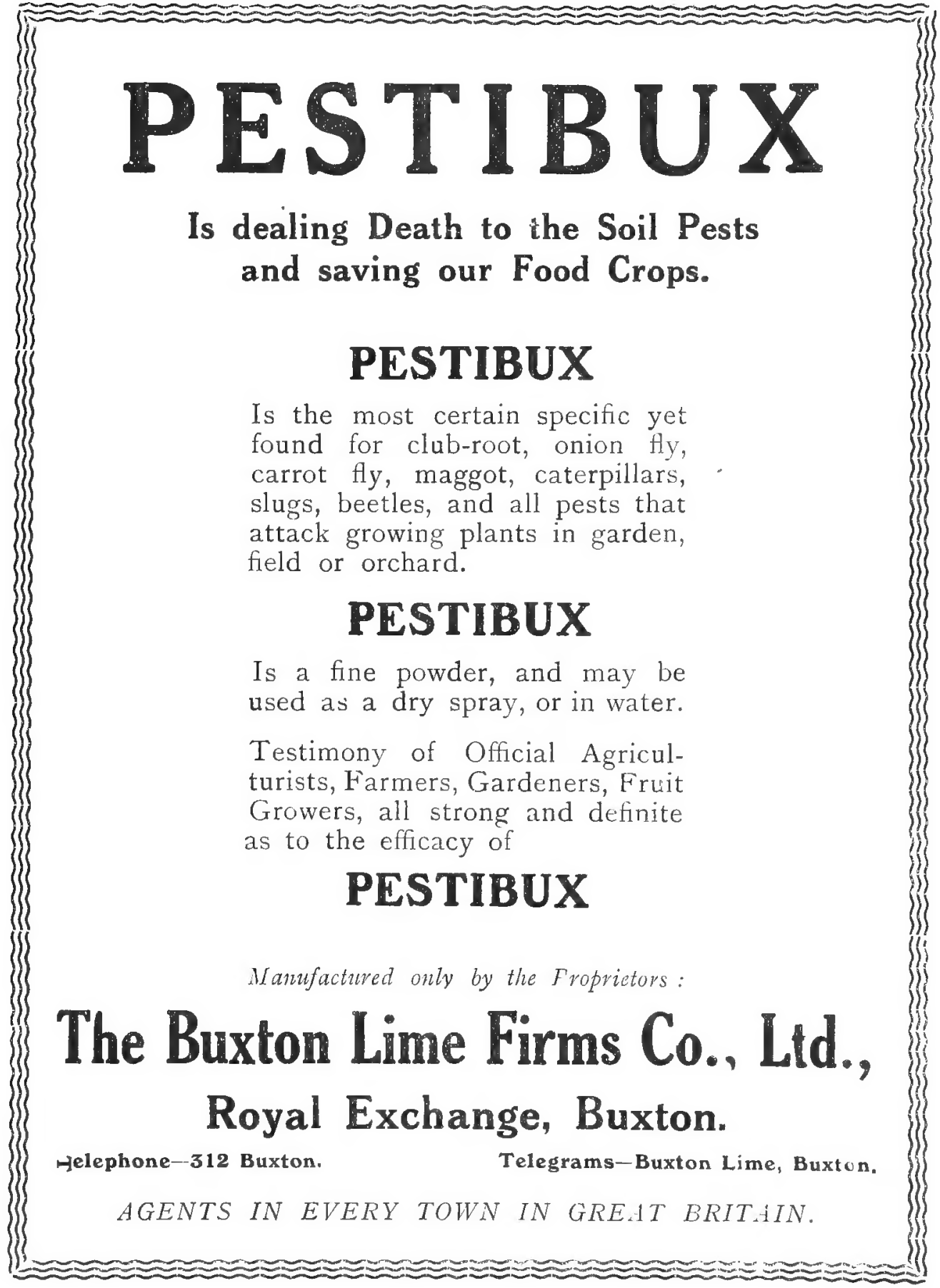




\section{vii}

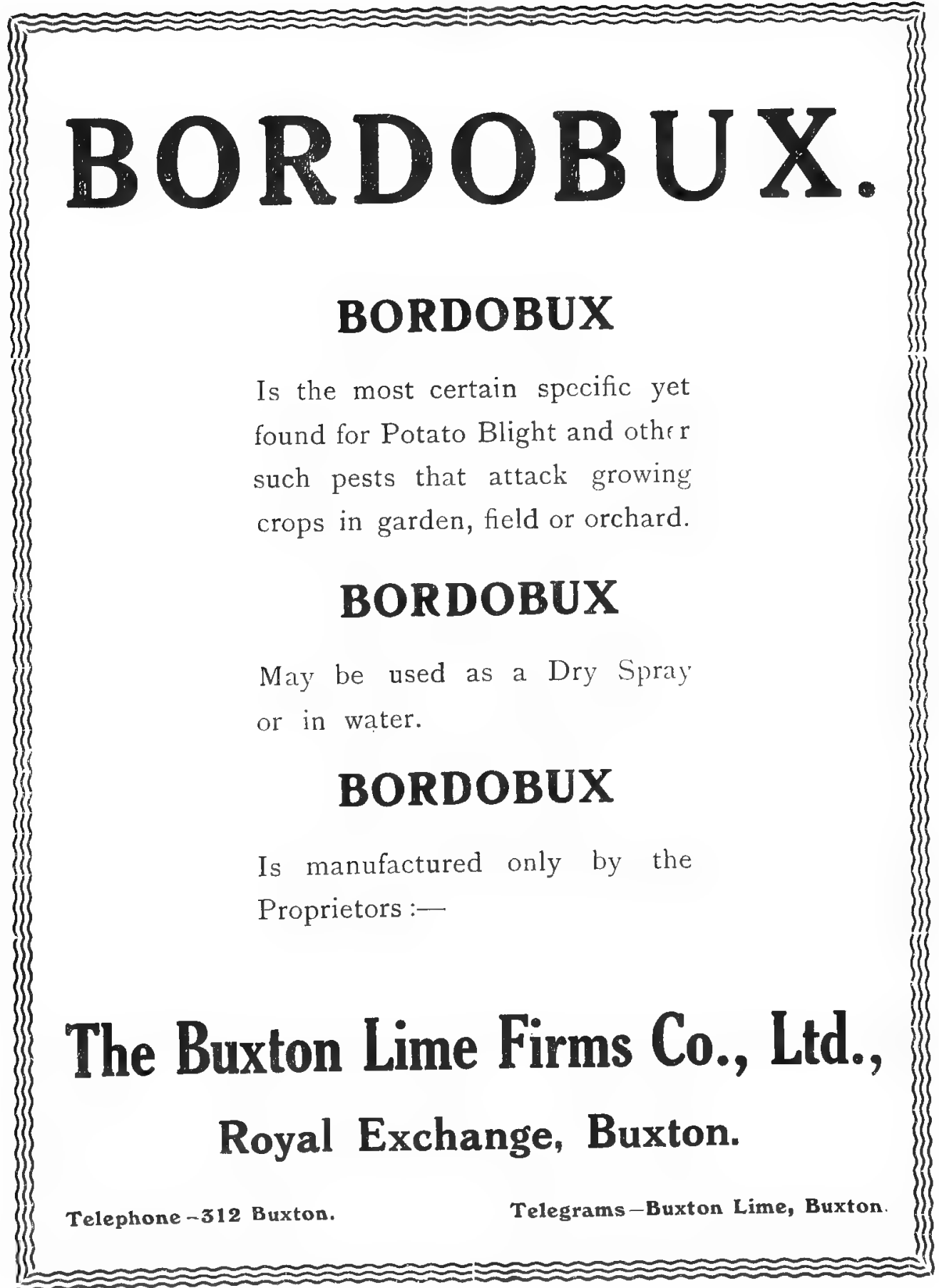


viii

The "FOUR OAKS" Pneumatic Battery Knapsack Sprayers

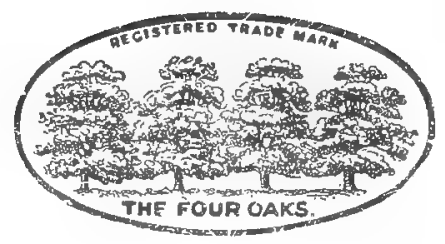
WITH CENTRAL CHARGE PUMP.

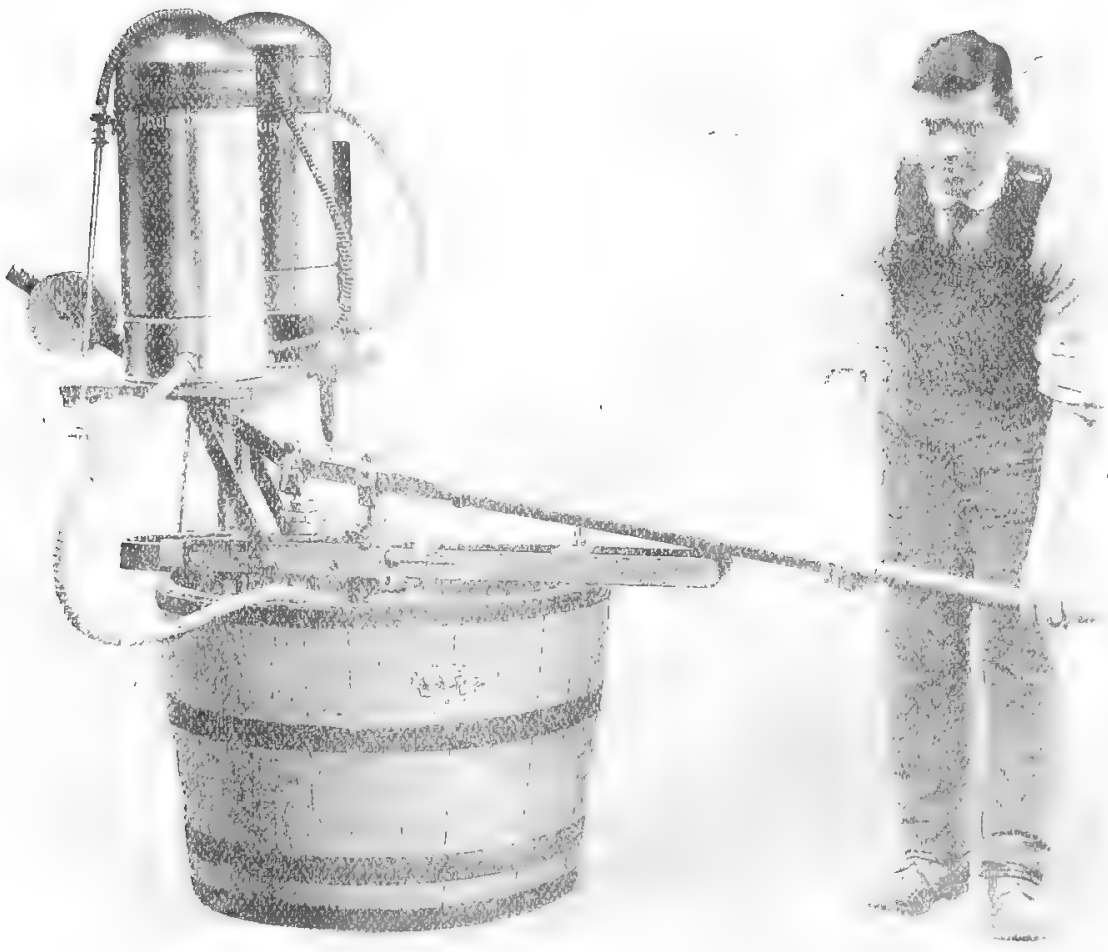

Illustration showing the "FOUR OAKS " Central Charge "ump, No. 1, "De Luxe" pattern, charging a "BATTERY" Knapsack Sprayer.

THE ABOVE IS THE VERY LAST WORD IN SPRAYING APPLIANCES.

Six to twelve men can easily be kept constantly spraying without any pumping action on their part.

For tull particulars of above and all other types of Sprayers aptly for Catalogues, post free, to the Sole Manufacturers-

THE FOUR OAKS SPRAYING MACHINE CO., Spraying Specialists, FOUR OAKS WORKS, SUTTON COLDFIELD, BIRMINGHAM. 


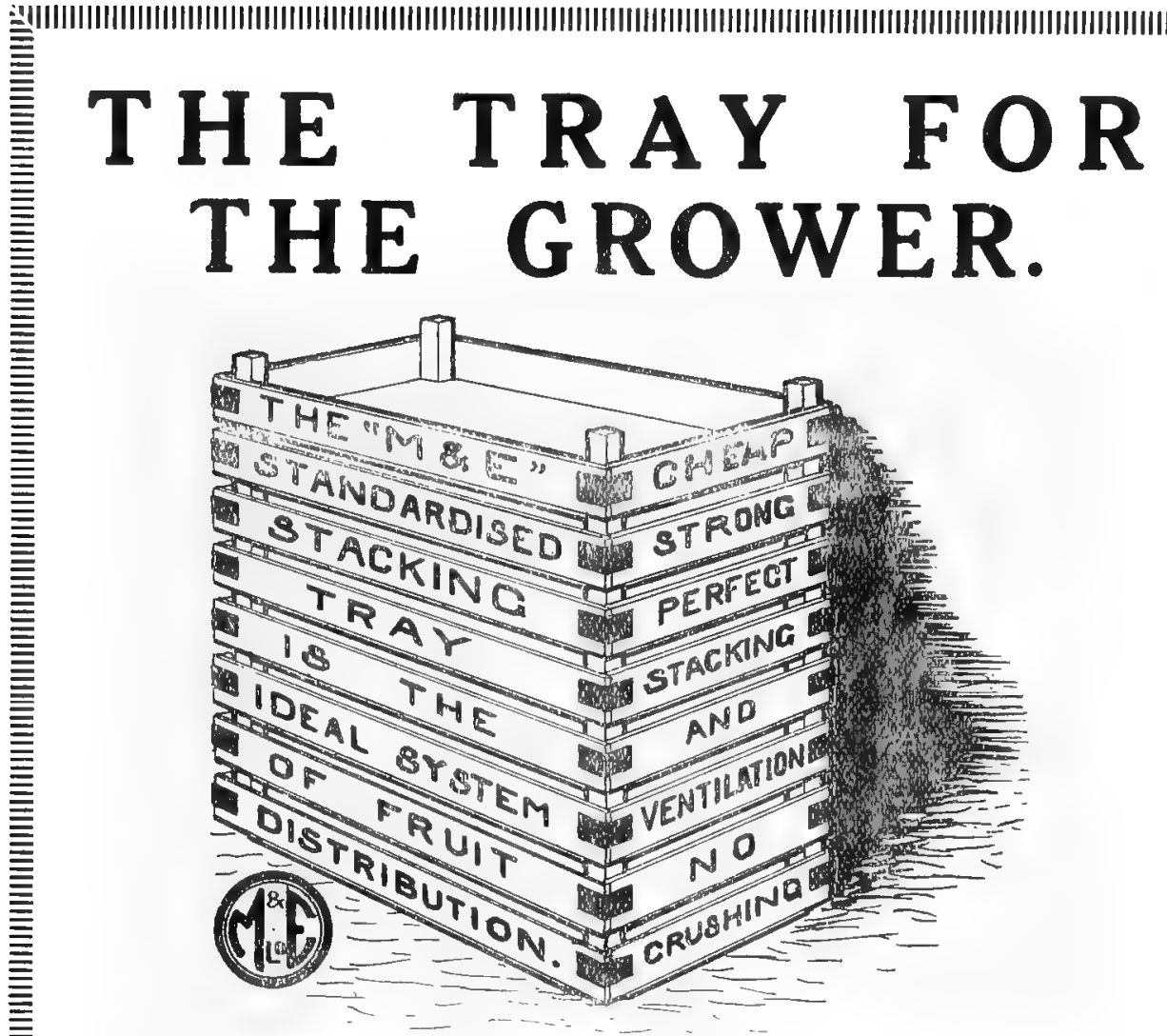

These Trays are Machine Printed, giving your business as a Fruit Merchant Excellent Publicity in Transit.

WE ALSO SPECIALISE IN ALL KINDS OF FLOWER BOXES.

\section{For P,ici and Further Details Apply- MALLINSON \& ECKERSLEY, Ltd,, SALFORD, LANCS.}

Telephones: 6I45 and 6r45 Central (Private Branch Exchange).

Telegrams: "BAYWOOD," MANCHESTER. 


\section{RIVERS' FRUIT TREES}

for Market Growers and Private Gardens.

Price List post free on application. Inspecton incited.

THOMAS RIVERS \& SON,

THE NURSERIES, SAWBRIDGEWORTH, HERTS.

(Station-Harlow, G.E.R.)

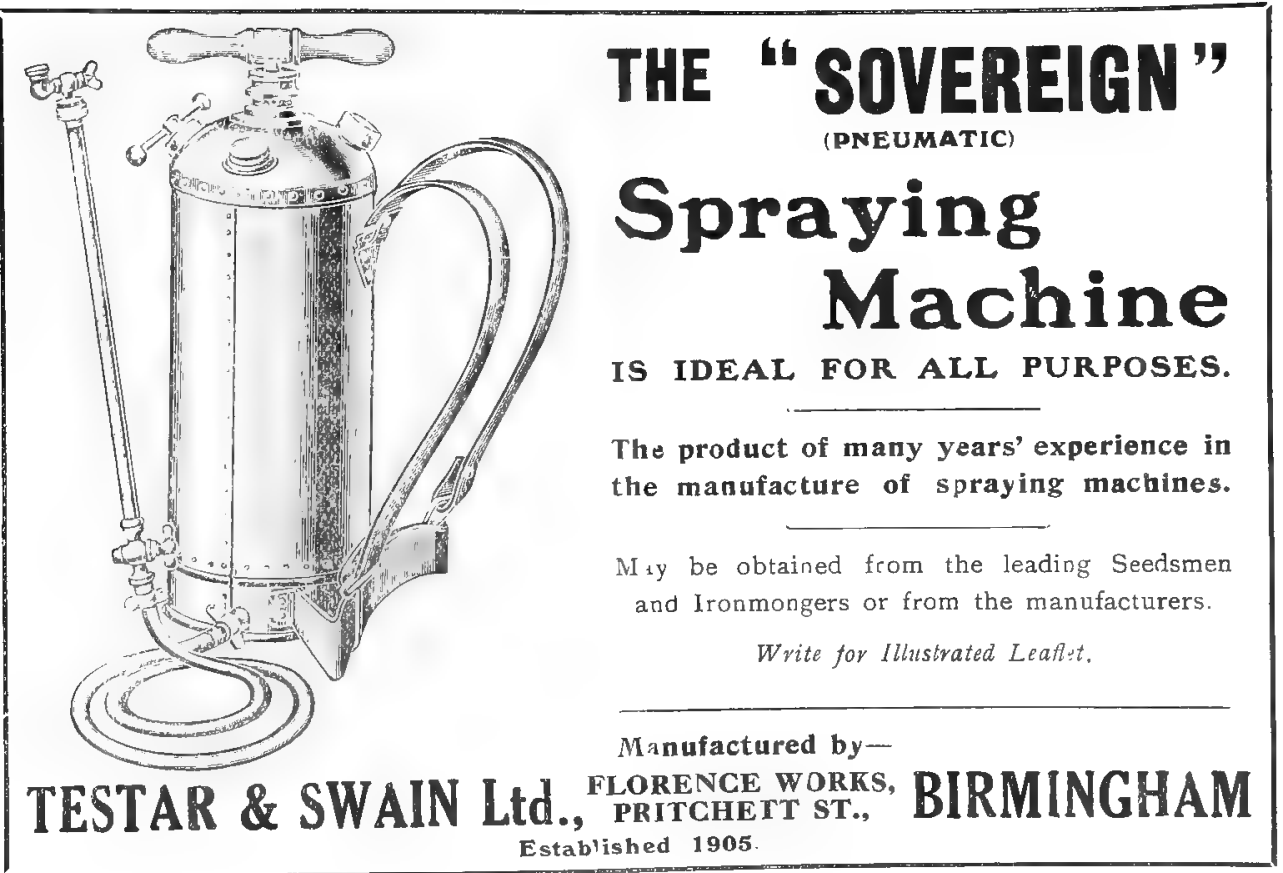

WEEKS'

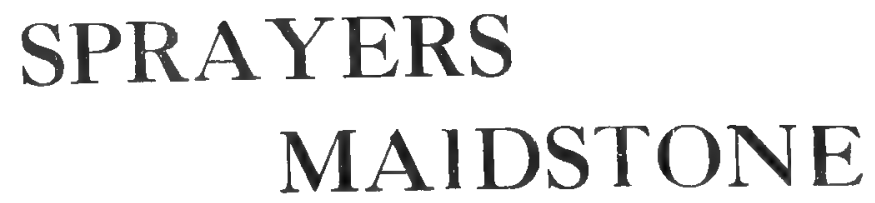




\section{J.D.CAMPBELL}

\section{- Manufacturer of}

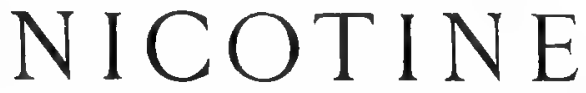

in Bond from duty-free Tobacco
Nicotine makes the very thest Insecticide for fumiagting, vapourising, or spraying to destroy insects infesting vegetation.

Your inquiries solicited.

LUND STREET, CORNBROOK, MANCHESTER.

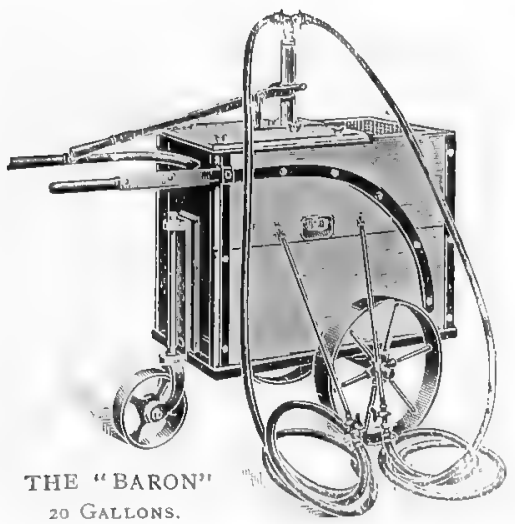

20 GaLlons.

" KILZALL" (Non-Polsonous) INSECTICIDE, Powder andiliquld. SAEE AND SURE.

"KILZALL" REIN FORCED NIGOTINE WASH. The Best In the Trade,

"KILZALL" IMPROYED BANDING GREASE. Effective an Lasting.

"KILZALL" A1 WINTER WASH. Free from Cau tic.

"KILZall" GaUstic Wash. The Bark Cleanser.

STONEHOUSE + IME SULPHUR. The Standard Wash.

"ABUNDA" FRUIT TREE FERTILISER, FOR HEAVY HEALTHY CROPS,
THE FRUIT FARMER'S FRIENDS.

'STONE-HOUSE" SPRAYING \& LIMEWASHING MACHINES, FRUIT TREE WASHES, FERTILISERS, ETC.

HAND \& POWER SPRAYERS TO SUIT ALL PURPOSES.

Please send for Price List. and Catalogues.

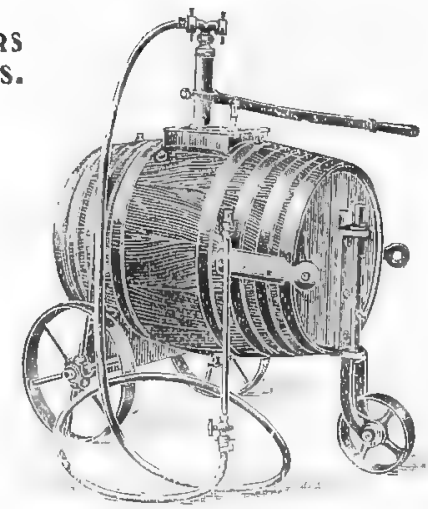

STONEHOUSE WORKS CD. WEST BROMWICH, STAFFS. The "FrUIT GROWER," 40 Gallon..

\section{BURGESS \& OLIVER,}

Weald of Kent Works, Horsmonden, Kent.

Makers of

\section{FRUIT \& HOP SPRAYING MACHINES}

For Hand or Power.

Special light portable power sprayers suitable for all purposes. 


\section{WE DESIRE NO HIGHER TRIBUTE!}

The most common question asked by Growers when offered othen

\section{INSECTICIDES, FUNGICIDES \& FERTILIZERS}

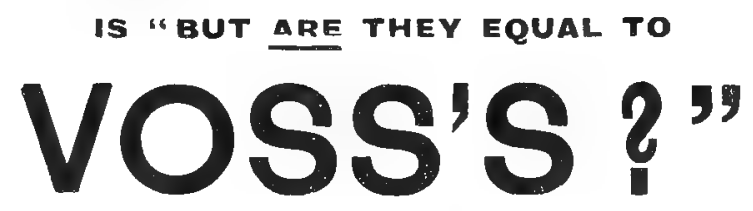

Sometimes

"THE LitTLE MORE"-often "THE MUCH MORE"MAKES "VOSS'S" UNIQUE.

\section{Leading Growers know this-Do You?}

8 Distinct "Voss" Insecticides and Fungicides have received-

8 Distinct Royal Horticultural Society Awards AFTER WISLEY TRIALS.

A Few of the Specialities which haye made the "Yoss" House Famous:

Voss Standard Lime Sulphur.

Voss Winter Wash, No. I.

Vossolite (Soil Insecticide).

Carlton (Voss) Arsenate of Lead.

Bordorite (Ready-made 'Bordeaux.')

Catterscab (Voss Bordeaux Arsenate).

Pterokyl (Special for Aphis and

Apple Sucker).

Nicovoss (Special for Aphis and Apple Suciser).
Carlton Green Sulphur.

Nicotyl Red Spider Compound (for Red Spider under glass).

SpidERene (for Red Spider in the open).

Cariton Strawluerry Dressing.

Carlton Sulphide of Potassium (Genuine Liver of Sulphur).

Creol-The Fluid. , Noted Soil Voster-The Powder, , Sterilizers. etc. etc.

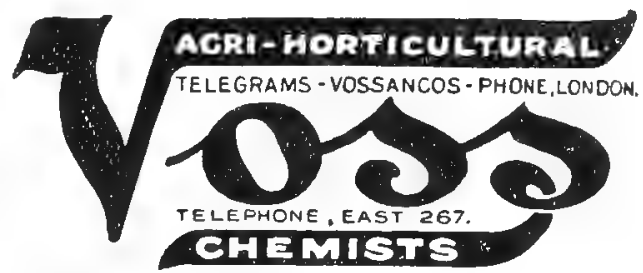

WALTER VOSS \& CO, LIMITED, $\because$ LONDON $\because E_{.14}$. 


\section{THIS SECOND EDITION IS DEDICATED \\ TO THE MEMORY OF \\ WALTER MARTIN,}

1828-1919,

as raiser of the valuable plum named by him Martin's SeEding or Pershore Purple, but which in fruit catalogues has been called the "Purple Egg Plum." On one of the Manor Cottages, No Gains, Pershore, where he lived, a Blue Diamond plum still grows. A flower of this tree was pollinated by Martin with pollen from Rivers' Early Prolific plum. He sowed the seed in a flower pot. In 1877 he moved to Broughtoy, 2 or 3 miles from Pershore, where he had rented 10 acres of woodland (Caddicroft), which he gradually grubbed. Here he planted his little tree. He grew fruit and vegetables for market. $\mathrm{He}$ took great interest in raising apples and plums from their seeds, and watched what their fruits were like, but the Pershore Purple was the best fruit tree he raised. He propagated it by suckers and grafting. It is a first-rate commercial plum, spreading over the country as its value becomes known; it is also a good stock for other plums. He cultivated his small holding up to 1900 . The land now belongs to Mr. Charles Watkins. The original tree is still in the hedge. In the garden of the old toll-house where he lived (and where his grandson now lives) may be seen other apple and plum trees that he raised from seed which are of interest. Like many benefactors to the human race he did not become rich, but was of a happy disposition and cortented. In March, 1919, when 91 years old, he was busy digging up plum suckers the day previous to his death. The inhabitants of Pershore some fifteen years previously presented him with a new tricycle when his old one, on which he had for many years brought his produce to Pershore Market, wore out. 


\section{THE GREATEST INSECTICIDE}

\section{SERVICE IN THE KINGDOM}

is without doubt that offered by

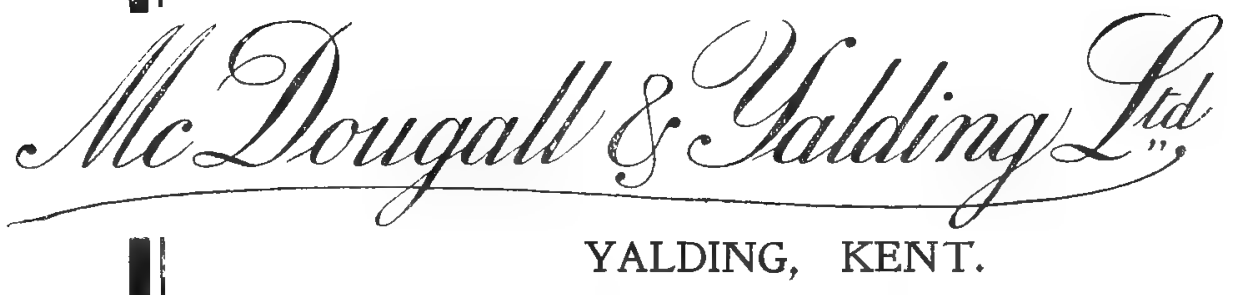

In addition to offering the following specialities, we would assure you that we are always willing to help if you have any "pest problems."

Frait Tree Washes,

McDOUGALL, No. 2

KATAKILLA

KENWASH

NICOTEX with Soft Soap POLVO

Specific Purpose Washes.

CAPSINE (for Capsid Bug.)

SPIDENE No. 1 (for Red Spíder)

ARSENATE OF LEAD and

ARSENOID (for Caterpillar)
Winter Washes. ARBORETAS SULFINET'TE

\section{"Chiswick" IMPERIAL SOFT SOAP OSTICO Banding Compound GLUTACK " , DRYMAC Powder Dry Spray}

Full particulars con'ained in our

FRUIT TREE WASH CATALOGUE. Write for a copy to-day. 


\section{PREFACE.}

New occasions teach new duties; Time makes ancien- good uncouth;

They must upward still, and onward, Who would keep abreast of truth.

LOWELL.

When originally invited by the Editor of the Fruit, Flower and Vegetable I'rades' Journal to write a series of artirles on Fruit Farming for that publication, to be subsequently supplemented and iswer in book-form as a reliable text-book for the industry, I felt it would be somewhat too heavy a responsibility for my individual effort. However, talking the matter over with a friend (one of the best cultivators and most successful fruit growers in Kent), he said: "We fruit growers are too busy with raising and selling our produce to write books, but if I can help you by telling you anything I will at any time gladly do so." Encouraged by this offer of assistance, I entered upon the task, and with the help of gentlemen recognised as autborities in the practice and in the science of the industry, I have endeavoured to give details of the best methods of management and practice, together with advice based on some ten year's' personal experience of the pleasures, difficulties and anxieties of fruit farming at Highlands, Swanley, Kent. Various work and visits bad taken me into most of the fruit-growing districts of Kent and other counties, and again I bave to thank many growers for so kindly showing me their plantations and patiently answering my numerous questions. Previously, in delivering courses of lectures on "Fruit Growing and Inseet Pests" for the Worcestershire Chamber of Agriculture at eleven different centres, I had taken the opportunity of visiting the principal fruit-growing districts in that beautiful county. A year spent among the fruit growers of the Cornwallis Vialley, in Nova Scotia, Canadid, enabled me to observe the good work of the Nova Scotian Fruit Growers' Association, its conferences, its fruit growing school for students and farmers (which I attended during the winter), its public demonstrations in pruning and spraying, and the spirit of co-operation which inspires the fruit growers of the province to work together for their mutual advancement; it also showed me the benefit of the telephone on the farm and the packing house at the railway depôt. What I saw convinced me that, although the best English fruit plantations are probably as well managed as any in Canada or the U.S.A., the majority of the fruit plantations and orchards in England are not as good as the average of those countries, where the growers are by nature progressive, the surroundings and climate helping to make them so. I was much struck at the time by the excellent bulletins issued by the agricultural experiment stations and by the Provincial Government departments. However, now our own Ministry of Agricul. ture has an excellent series of leaflets on fruit cultivation, insects, diseases, etc., which all fruit growers or intending growers will do well to read, mark and learn.

In these strenuous times home growers, in order to maintain pre-eminence in our own markets, must work shoulder to shoulder and cease to look upon their immediate neighbours as competitors, but rather as brothers with common interests.

For this second edition the whule work has been carefully revised and in many cases rewritten. Several specialists have kindly contributed valuable chapters, as will be noted by a glance at the Table of Contents. I sincerely hope the book will help the monetary side of fruit growing, and also add interest from the many points of view from which the subject is dealt with

Oxenturn House. Wye, Kent; CecIl HeNRY HOOPER. June, 19,21 . 


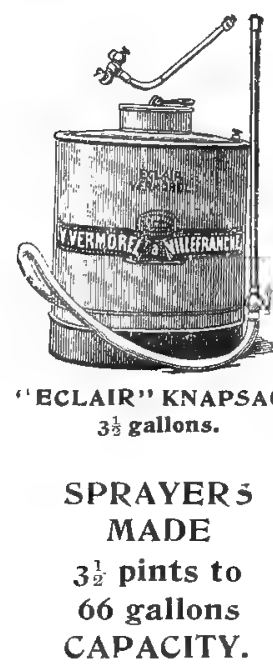

SPRAYING

LIME = WASHING DISINFECTING

VERMOREL "ECLAIR"

MACHINES.

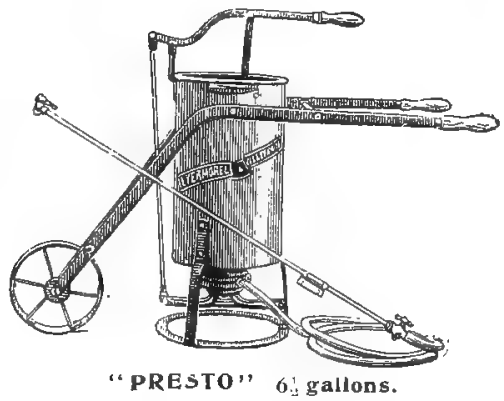

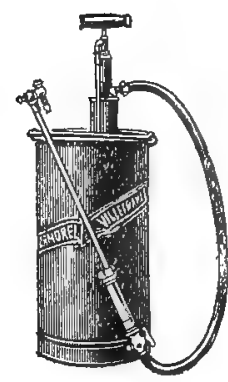

"SALVA"

BRASS ALLOY

$3 \frac{1}{2}$ gallons.

STOCKS

HELD.

CATALOGUE of FULL RANGE of MODELS and DE TAILS of TYPES ILLUSTRATED Irom COOPER, PEGLER \& CO., LTD., 24a-26, CHRISTOPHER STREET, FINSBURY SQUARE, LONDON, E.C.2.

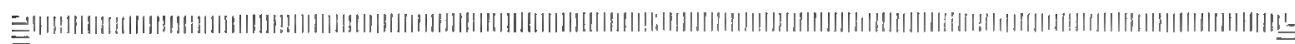

\section{PLANTERS OF FRUIT TREES}

\section{TRY MERRYWEATHERS.}

Don't Fail to Plant

Bramley's Seedling

The most satisfactory Apple grown.
The Damson for Profit is the "Merryweather." Send for details.

Apples, Pears, Plums, and all other Marketable Fruits a Speciality.

Send for Catalogue free on application.

\section{H. MERRYWEATHER \& SONS, LIMITED,}

\section{Southwell, Notts.}




\section{CONTENTS.}

\section{IRITT FARMING: PRAC'TICAL AND SCIENTIFIC. IS) ('ECIL, H. HOOIER, F.S.I.}

\section{CH.IPTER I - How and what to Learn to become a Fruit Farmer}

PAGE

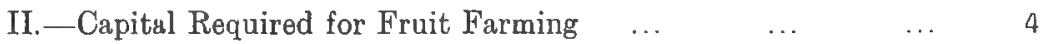

III._On the Selection of a Farm for Fruit Growing $\quad \ldots \quad 7$

IV.-Arrangements between Landlord and Tenant as to Fruit.

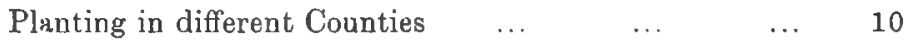

$\mathrm{V}$ - The Law in Relation to Fruic Farms and Market Gardens,

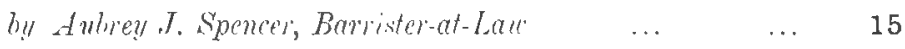

VI. -Soil, Site and Shelter for Fruit Plantations, by Ernest .1T. Bear 19

VII.-Soil Cultivation in Fruit Plantations, by Erntist ll licar 22

VIII.-The Setting-Out of Fruit Plantations and Orchards _. 27

IX. -The Field Cultivation of the Strawberry, by i'ecil H. Hooper

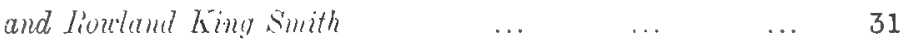

X.- The Field Cultivation of the Raspberry, ly Cecil H. Hooper

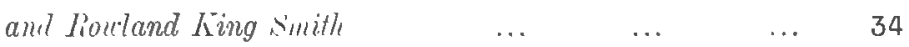

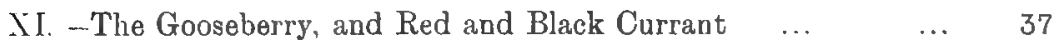

XII.-The Commercial Cultuation of the Logauberry, by Geoffrey $\begin{array}{llllllll}F . \text { Hooper } & \ldots & \ldots & \ldots & \ldots & \ldots & 43\end{array}$

$\begin{array}{lllllll}\text { XIII_The Apple } & \ldots & \ldots & \ldots & \ldots & \ldots & 46\end{array}$

$\begin{array}{llllllll}\text { XIV. - The Pear } & \ldots & \ldots & \ldots & \ldots & \ldots & 54\end{array}$

$\begin{array}{lllllll}\text { XV. The Plum and Damson } & \ldots & \ldots & \ldots & \ldots & 57\end{array}$

$\begin{array}{llllllll}\text { XVI.-Cherry Orchards } & \ldots & \ldots & \ldots & \ldots & \ldots & 61\end{array}$

$\begin{array}{lllllll}\text { XVII._Cob and Filbert Nuts } & \ldots & \ldots & \ldots & \ldots & 64\end{array}$ 
$\begin{array}{llllll}\text { Chapter XVIII__Picking, Grading and Packing } & \ldots & \ldots & \ldots & 68\end{array}$

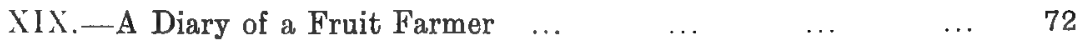

XX.—Spraying and Spraying Machinery, by (t. For Hil.on $\quad \ldots \quad 76$

XXI.—Spraying with Lime Sulphur, by Arthur Miskin $\ldots \quad \ldots 8$

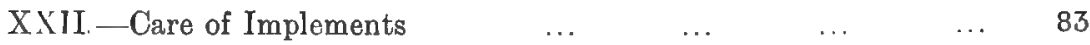

XXIII._Spraying Apple Plantations with Large Plant, by (.. Murdoch 85

XXIV. -The Nature and Uses of Manures, by W. S. Gray, L.Sc. $\quad \ldots \quad 89$

XXV — Soils in Relation to Plant Food and Growth _.. $\quad \ldots \quad 91$

XXVI.- The Manuring of Fruit Trees and Bushes, by Bernard $\begin{array}{lllllll}\text { Dyer, } D . S C . & \ldots & \ldots & \ldots & \ldots & \ldots & 93\end{array}$

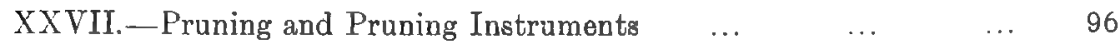

XXVIII.-Fruit Trees and the Soil, by A. R. Horwood, F.L.S. $\quad$.. 99

XXIX. - Birds in the Orchard, by Frederic Smith ... $\quad \ldots \quad \ldots \quad \ldots 3$

XXX.-Wild Birds in Relation to Fruit Growing, by II alter E.

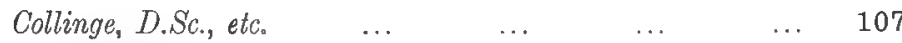

XXXI.—Some Comparisons of English and Australian Fruit Growing,

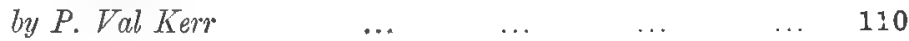

XXXII - A History of Fruit Growing in Canada $\quad \ldots \quad \ldots \quad \ldots 114$

XXXIII. - Some Fungoid Diseases of Fruit Trees, by H. Wromald, D.Sc. 116

XXXIV.-The Commoner Fruit Pests, by C. A. II. Duffield, F.E.S. .. 125

XXXV.-Life History of some well-known Apples $\quad \ldots \quad \ldots \quad \ldots 135$

$\begin{array}{lllll}\text { XXXVI.-The History of some well-known Pears } & \ldots & \ldots & 139\end{array}$

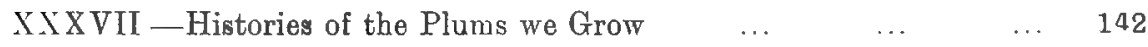

$\begin{array}{llllll}\text { XXXVIII.—Notes on the Origin of some Cherries } & \ldots & \ldots & \ldots & 145\end{array}$

XXXIX.-Experimental Work on the Self-Sterility of the Apple, by

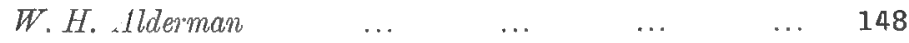

XL.--Results of the Study of the Pollination of the Apple _. 150

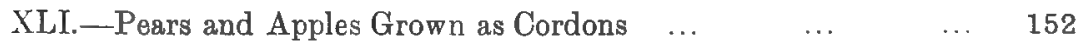

XLII.-The Raising of New Varieties of Fruit Trees and Experiments in Double Grafting, by $W^{r} m$ C. $u m p$, T.N.H. $\quad \ldots \quad 154$

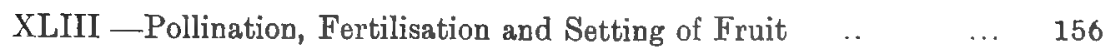

$\begin{array}{llllllll}\text { XLlV._Black Currant Cuttings } & \ldots & \ldots & \ldots & \ldots & 161\end{array}$ 


\section{USE THE}

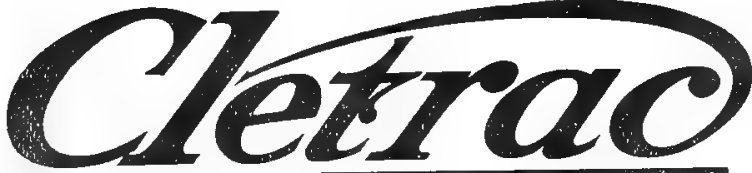

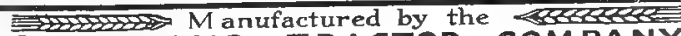
CLEVELAND TRACTOR COMPANY
TRACTOR

FOR

MYRK IN

ORCIA ARDS.

Among trees the Cletrac is remarkably efficient. It ploughs close up to trunks and goes under low hanging branches, being built low.

It is essentially the fruit grower's machine.

\section{BRONZE MEDAL IN THE LINCOLN TRAGTOR TRIAL.}
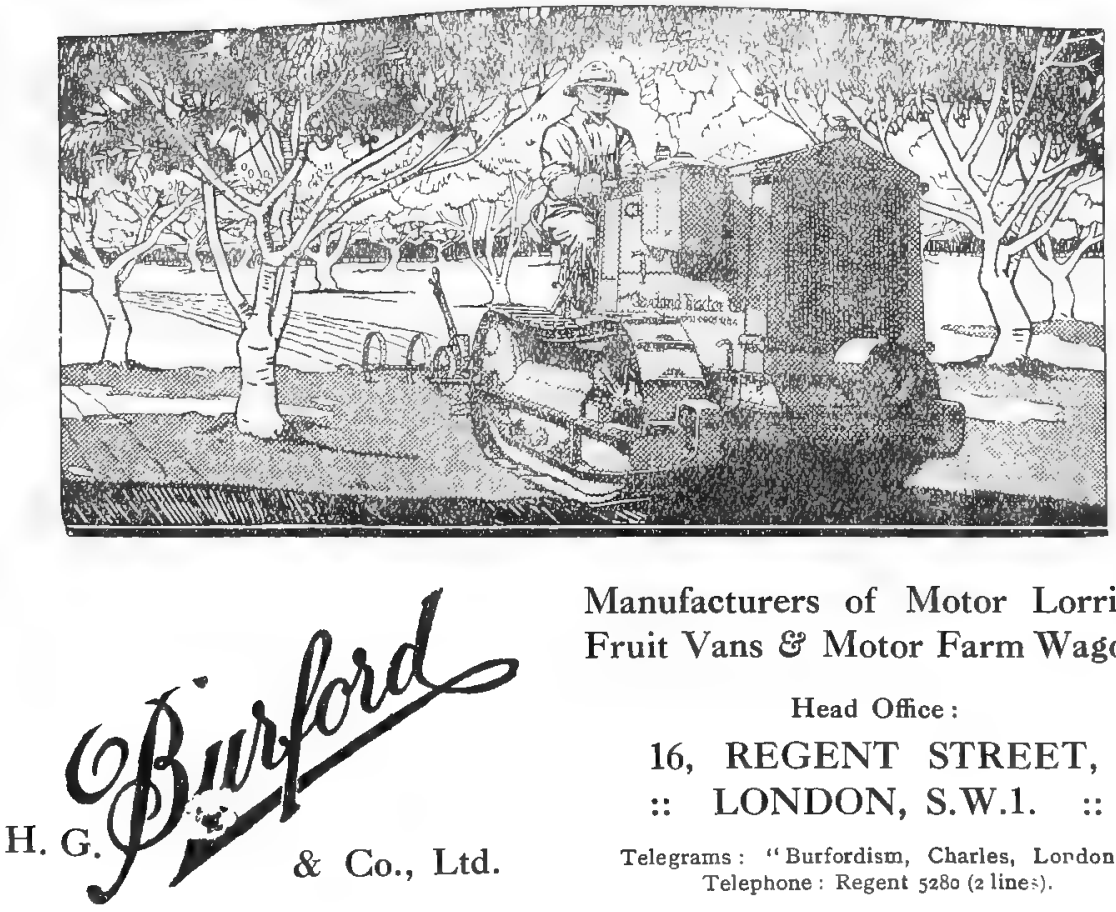

Manufacturers of Motor Lorries, Fruit Vans \& Motor Farm Wagons

Head Office :

16, REGENT STREET, :: LONDON, S.W.1. ::

Telegrams: "Burfordism, Charles, London." Telephone: Regent 5280 (2 lines). 
$\begin{array}{lllllllll}\text { Chapter } & \text { XLV. -Regrafting of Fruit Trees } & \ldots & \ldots & \ldots & \ldots & 163\end{array}$

XLVI._Grading and Packing Fruit for Marker, by T. J. Poupart ... 165

XLVII.-Cost of Preparation of land Before Planting and Cost of Fruit Planting (1920-21) $\quad \ldots \quad \ldots \quad \ldots \quad \ldots 173$

XLVIII._Land Measurement and Surveying in Relation to Fruit Growing, by A. H. Haines, P.A.' I. $\quad$.. $\quad \ldots \quad 177$

XLIX.-Book-Keeping for Fruit Farmers and Market Gardeners,

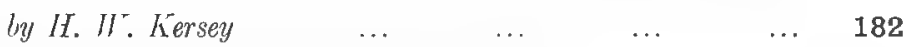

L. - Historical Record of English Fruit Growing _ $\ldots \quad \ldots \quad 186$

$\begin{array}{llllllllll}\text { APPENDIX } & \ldots & \ldots & \ldots & \ldots & \ldots & \ldots & \ldots & 192\end{array}$


xxii

\section{THE BELUMNITE SYSTEM OF DRY SPRAYING}

The Advantages may be Summarised as follows:BELUMNITE is always ready for use and requires no mixing. It cannot be used too strong or too weak. It is always effective and always effectively alike.

A great economy of labour invariably follows the use of our BELUMNITE System of Spraying, by doing away with delays through mixing washes, carting water, pumps breaking down, and nozzles being choked.

It secures for you a maximum of work from your staff, since each becomes self-contained and requires no second hand to keep up supplies or pump.

BELUMNITE is more penetrating than any wet system of spraying. BELUMNITE works out at less cost than any wet spray.
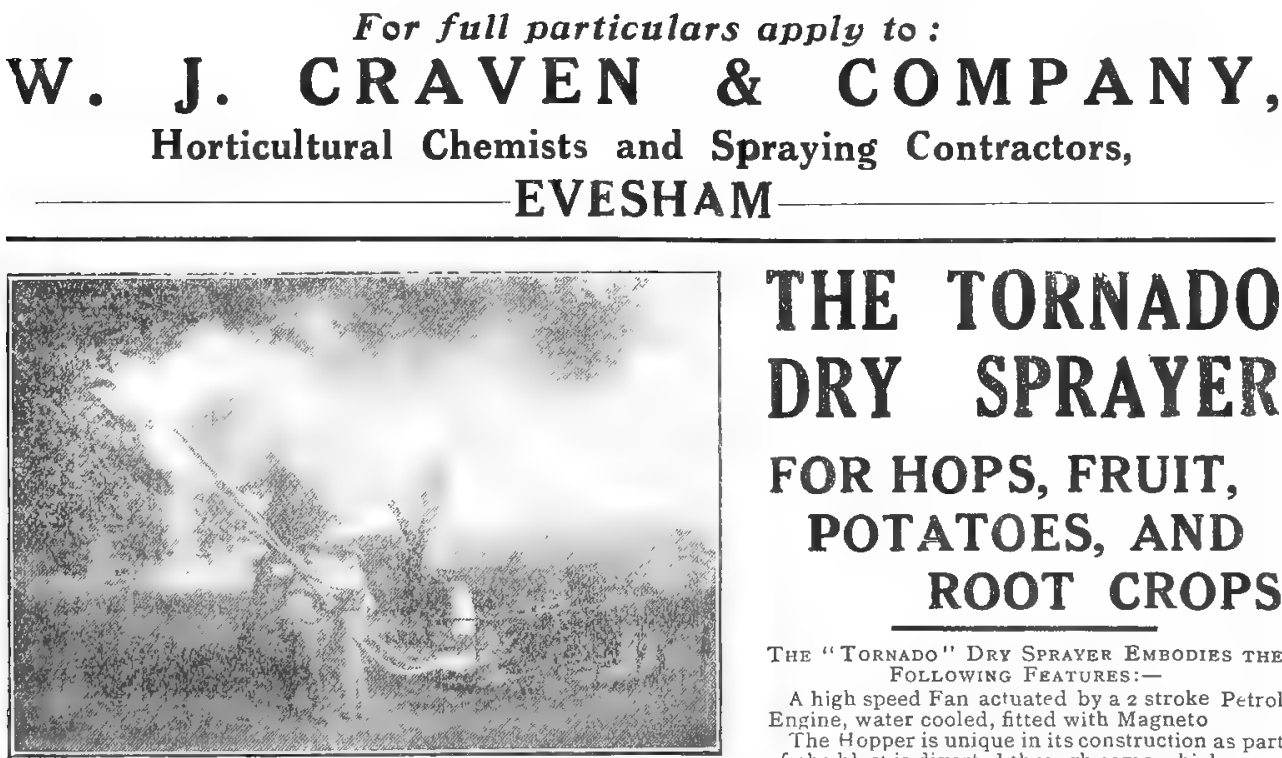

ThE "ToRnado" DRY SPRaYer EMBodies the Following Features:-

A high speed Fan actuated by a 2 stroke $P \in t r o l$ Engine, water cooled, fitted with Magneto

The Hopper is unique in its construction as part of the blast is diverted through same which gives an even delivery of powder.

The amount of powder applied can be regulated from a few pounds up to $\frac{1}{2}$ cwt. or more per acre according to the nature of work done.

Flexible pipes are fitted with extension tubes so that tall trees, etc., can be sprayed with ease.

The machine can be used for Fruit Plantations of all d scription, Hop Yards, Potato Spraying, etc.

The "TORNADO " DRY SPRAYER reduces labour to one fifth of that required for wet spraying.

The "Tornado" Dry SPRAyr is Being Used for the Following Purposes:Dry Spraying Hops against Aphí, Red Spider, Turnip Flea, and Fungus Disease日. Bush Apples, Apple and Cherry Orohards, Black Currant Plantations.

Fineyards against Insect Pests and Fungus Diseases.

Potato Crops against Potato Disease.

Root Crops against Turnip Flea, etc.

For further particulars a ply:-Patentee, J. C. BAKER, 48, Foregate St., WORCESTER or Wholesale Distributing Agents:-W. J. CRAYEN \& C0., 48 \& 60, Port St., EVESHAM. 


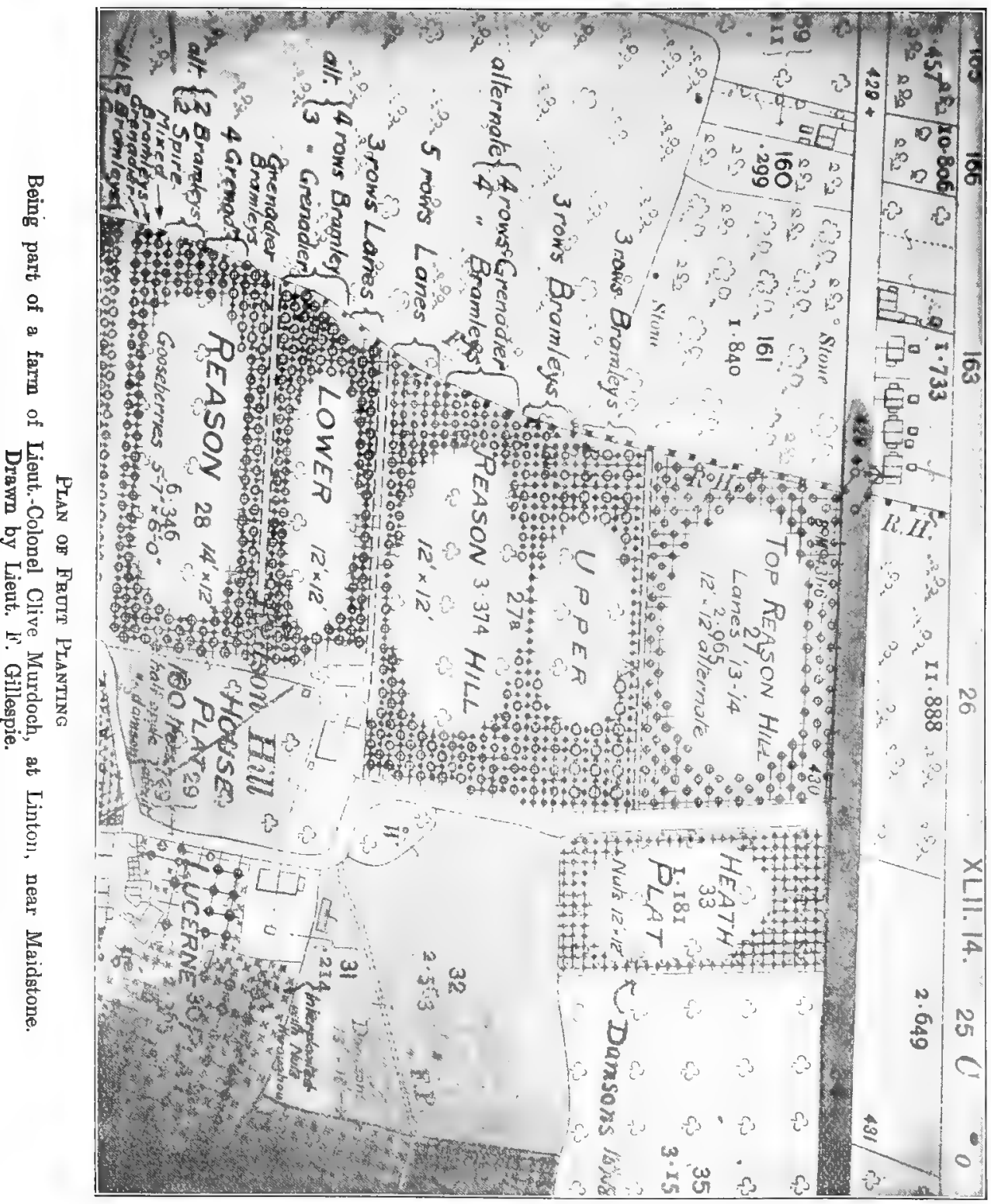



('HAPTER I.

\section{HOW AND WHAT TO LEARN TO BECOME A FRUIT FARMER.}

The question a man or woman intending to take up fruit growing as a business has to decide is how to learn the business, whether he or she should learn it at a college, or on a farm, or on both. Thos: in authority at a college will always say that while a great deal can be learnt at a college, the intending grower must also go to work on a well-managed commercial fruit farm, for two years, if possible, to learn the management of labour, buying and selling, etc., and the close financial part which the college training is not so well adapted to impart. A month or more in the fruit season spent with a fruit salesman is also a useful business training. Let us examine some of the subjects of which it is advisable for the fruit farmer to have more or less knowledge, whether he attends an agri-horticultural college or not. There is a great deal that can be learnt from text-books and the horticultural journals without attending lectures, but it needs greater patience to study alone, and subjects like chemistry, plant diseases, and insect pests are certainly far more easily studied in lectures, laboratories and museums, than in one's parlour on the farm. Actually fruit farming is nearly always combined with market gardening, general agriculture, dairying, or poultry, but we will limit our considerations to subjects directly affecting fruit farming.

Practical Work.-The student should try to learn the right time and the right way to do every operation on the fruit farm; pains and practice make the work efficient and quick; being able to do it one's self has a secondary advantage in being able to judge whether another person is doing it well, and in being able to show how to do it. A student on a farm is often asked to pay the wages, which teaches him accuracy and business.

Pomology.-Includes special attention to the requirements of the different kinds of fruit, study of growth of the tree, and the fruit of different commercial varieties; recognition of the different varieties, their inerits, and faults, and season (and even their history). Planting, cultivation, propagation, picking, grading, packing and marketing of the different fruits.

LAND MEASURING. - Includes finding areas and making plans of fields and orchards of various shapes; recording the varieties planted on a plan; taking levels for supply of water, or drainage of land; understanding the ordnance and geological maps.

Building Construction. - A slight knowledge of materials and construction of sheds, etc.; elementary carpentry, for repair and upkeep of buildings and machinery.

Fencing.-Of various kinds, wire, live fences, hedges, wind breaks.

Farm Roads.- Their making and upkeep. (A jolty road will damage strawberries and even apples.)

Machinery.-A knowledge of the construction of and adjustment of ploughs, harrows, rolls, drills, markers and the smaller implements and tools, and care of same. Spraying machinery construction, regulating and cleaning out of knapsack, tanks and motor spray-pumps; wind pumps; hydraulic ram; boilers: steam, oil and petrol engines as motor power. Telephone.

Farm Management and Economics. Principles underlying the selection of a farm, whether for renting or purchase, rates, taxes, tithe, quit rent. Capital required to stock and develop fruit plantations; judging a horse; management and cost of labour, piece work, judging work, fixing prices. Possibilities of cooperation with neighbouring growers, or profit-sharing with workers. Aim at producing the greatest quantity of the best quality fruit at the least cost, and at getting the fruit into the hands of the con- 
sumer in the best condition in the shortest time, and at a reasonable price; if successful give the workers a bonus.

Account Keeping. - Wages book or journal, invoice book, cash book with columns to analyse under headings the amounts received and spent, bought and sold books or ledger of unpaid accounts, money due and money owing; cheque book, paying-in book, pass book. The object of accounts is to show where one stands, and at the end of the year whether there is a profit or loss. For the purpose of Income-tax, the receipts and payments have to be analysed into headings such as rent, wages, manures, implements, etc. For this purpose an inventory and valuation should really be made yearly. An account should be kept of packages (empties). It may be well sometimes to keep cost of certain crops, as to yield, etc., to see whether they pay.

BEE-KEEPING.-To handle and manage bees throughout the year; the diseases of bees and their treatment.

If the fruit farm pupil goes to College he should learn:-

Horticultural Chemistry.-The necessary elements required by plants; the various manures, their uses and what they supply; to understand a chemical analysis of a manure and value a manure from its chemical composition; what manures can be mixed and what should not be mixed; test a soil for lime in the field. Be able to interpret to some degree a soil analysis. Study results of experiments in the manuring of different kinds of fruit. Have some. knowledge of the composition of fungicides and insecticides, and what substances can be mixed, and which are unsuitable for mixing. Hard and soft water.

Botany.-How plants grow, and how plants feed, structure of a plant and the functions of its different parts; knowledge of the common weeds and their destruction; principles involved in keeping plants in health; physiology of taking cuttings; winter and summer pruning; grafting; budding; plant reproduction; plant-breeding; pollenation and fertilization; to distinguish flower and leaf buds in the various fruit trees and bushes; the stocks used for different fruits.
Plant Pathology, - Recognition, prevention and cure of the more conmon fungous and bacterial diseases of fruits, together with their life-history, including apple and pear scab, brown rot of plums, cherries and apples, American gooseberry mildew, apple canker, cherry leaf scorch, peach leaf-curl, silver leaf, die-back of gooseberries, strawberry mildew; be able, to prepare and mount microscope slides of plant diseases; make up Bordeaux mixture, lime sulphur (understand hydrometer), winter and summer strength spraying. Powder dusting. Uses and costs of different fungicide applications. The control of insects and fungous pests by legislation.

ZOOLOGY AND ENTOMOLOGY.-The influence of the common animals and birds on fruit-growing; useful insects; injurious insects, their life histories, prevention and remedy, including codlin moth, apple sawfly, apple sucker, woolly aphis, winter and allied moths, lackey moths, the various aphides, apple blossom weevil, raspberry and loganberry beetles, gooseberry sawfly and magpie moth, black-currant gall mite, red spider, wasp, scale insects, capsid bugs. The proportions and methods of mixing the standard insecticides for winter and summer washes for the various insects; some knowledge of the caustic washes, lime spray, emulsions, poisons, nicotine wash, and whether they may be mixed to kill more than one class of insect at a time; the relative cost per 100 gallons of different sprays; quantities required per tree or per acre. Knowledge of the best trade insecticides and fungicides. Dust insecticides; fumigation, grease banding, soil sterilization.

GEology.-The relation of top soil to subsoil and underlying rocks; the likes and dislikes of plants as to soil and moisture in soil; influence of local geology on wells, water supply and drainage; what a mechanical analysis of a soil is; the classification of soils (sand, clay, humus, lime, loam, etc.); cover crops.

Meteorology and Physics.-Heat and light, their influence on a favourable aspect, earliness, influence of colour of soil; evaporation, dew, mist, mist-line; influence of water, river, lake and sea on fruit growing. Foretelling of frosts in 
spring; smudging and orchard heating. Gales, direction of prevailing winds, wind breaks; local geography of district in which one lives. Rainfall and temperature as influencing crops.

Law in Relation to Fruin-Growing.If land is to be rented, ascertain two things: (1) that the land is suitable for fruit-growing; (2) that the landlord is in sympathy with the use of his land as a fruit farm, and will compensate you on quitting if you have really improved the letting value of his farm by planting fruit. Study the Agricultural Holdings Act as regards fruit planting, realise that the words "this farm is let as a fruit farm," must appear in the agreement or lease, in order to be able to claim compensation for fruit planting. Solicitors who control and manage estates appear to think it their duty to be unfair to the fruit farmer, and omit the words, or put in something to make the Act not apply. Beware! If no compensation is agreed, insist on the lease being for 21 years or longer. Deal with the landlord himself, or his ngent, rather than with a solicitor, who knows nothing about land management, and cares nothing about the property, except for grinding rent out of it. A landowner, of course, has a right to know what acreage a tenant wishes to plant, and what compensation would be likely to be. Do not enter the farm till all points in the agreement are on paper and you have agreed to them. The best English landlords are the best in the world; many take personal interest in their estates and in the wel- fare of their tenants; choose one of them and prove yourself worthy.

An agreement for one or two years can be drawn up by a land agent, but a lease for three or more years must be drawn up by a solicitor, for the latter there is a scale of fees based on the rental. The cost of the lease should be borne equally by landlord and tenant. The cost of a lease can be arranged beforehand independent of the scale.

Land Purchase and Enfranomisement OF COPYHOLD. - If purchasing land or a farm, study the system of National Land Registry; the office is in Lincoln's Inn Fields, London. It is the best possible system, adopted in Canada and other Colonies. The deeds are registered once for all and a property can be transferred in half an hour by buyer and seller meeting at the Land Registry, instead of a squabble between solicitors lasting, say, half a year, thus saving time and money. C. H. H. has had some experience. If one wishes to enfranchise copyhold land and redeem "quit rent." get it carried through by the Ministry of Agriculture, rather than by solicitors. I know of one case in 1920 in which the buyer and seller of a property had to pay £20 between them to get rid of the copyhold tenure and annual quit rent of $2 \mathrm{~s}$. on an acre of grass land. England wants inexpensive and quick transfer of land, the heary expenses, largely owing to legal expenses. are a tremendous hindrance that should be done awny with for the good of the country. 


\section{CHAPTER II.}

\section{CAPITAL REQUIRED FOR FRUIT FARMING.}

Preparation of Land for Fruit Planting.

With regard to the best and most economical method of preparing land for fruit planting, one of the largest and best cultivators of fruit in Kent steam cultivates his land intended for planting, after dunging it, ploughing 9 inches deep and subsoiling 9 inches deeper. The subsoil is only stirred and not brought up to the surface.

The manuring would be either dung, costing $\$ 7$ per acre, or, as he pore often uses for fruit, one ton of wool waste and half a ton of bone meal, costing a little under $£ 5$; steam cultivating $£ 2$; total $£ 7$ (pre-war cost).

Potatoes form a good crop to precede fruit, if manured well with dung and artificials and well worked.

It is very important to have the land thoroughly clean of weeds before planting, as if couch grass gets among the roots of trees or bushes it almost involves . digging them up in order to get the weed from the roots, Convolvulus or bindweed is also a very tiresome weed among fruit. Dandelions are troublesome if among strawberries.

\section{The Start.}

Supposing a man starts with 12 acres ut suitable land, either buying it at, say, £35 per acre, or renting it at 30s. to 50s. per acre, with an equitable agreement with his landlord as to compensation if his plantations are successful in c'ase he has to leave. The soil is good, the land fairly high lying, consisting of 6 acres on each side of a high road, within half a mile of a railway station, or within, say, four miles of a seaside resort. The two fiolds are surrounded by good hawthorn hedges, and there are no rabbits and hares that in an ordinary way enter these fields. If fencing is required against rabbits, and for protection, the present cost is about 1s. per foot run, or about $£ 10$ per acre. After the land has been ploughed, followed by subsoiler, or deep steam cultivated, a roadway is made through the centre of each field, and planting is commenced, consisting in one field of bush apples, chiefly on broadleaved paradise stock, 12ft. apart; black currants, $6 \mathrm{ft}$. by $3 \mathrm{ft}$, probably strawberries between, and possibly with onions sown between these in the first year. The other field may be plums or Morello cherries, with a few pears, with, say, raspberries, gooseberries or red currants between. Pears do not thrive and pay everywhere, by any means.

This little farm may employ one or two men, as well as the owner, and the latter must endeavour to limit his expenses for three or four years, to, say, $£ 60$ to $£ 100$ a year for personal expenditure, and stick close to his work.

With regard to the buildings, I would suggest as desirable for a 12 acre fruit farm an arrangement as follows, wooden buildings with corrugated iron roof and weather board sides.

My late friend, Corporal A. D. Nickalis, when carpentry instructor at Wye Agricultural College, kindly calculated the cost of such a building, 56ft. long, $12 \mathrm{ft}$. wide, 8ft. high to eaves; packing shed $21 \mathrm{ft}$. long; office 8ft.; cart shed, 15ft.; tool shed, 6ft.; stable, 6ft.; as follows:Plates, 17s. 6d., £1 3s. 4d.; posts, 6s.; studs, $£ 3$ 6s. 8d.; rafters, £2 13s. 4d. ; tie beam, 8s. 4d.; weatherboard. £5 14s.: 7 windows, $£ 55 \mathrm{~s}$; 6 doors, $£ 1$ 15s.; purlin, $£ 1$ 1s. 8d.; partitions, $£ 2$ 18s. ; roof (iron), $£ 105 \mathrm{~s}$.; fioor to office, £1 5s.; packing benches. $£ 1$ 3s. 6d.: labour, £14 10s.; creosote, 7s. 6d.; nails, $£ 1$ 2s. 6d.: total $£ 52$ 2s. 4d. If lined, £8 1s. 6d.: if brick foundation, £6 extra. Total, $£ 683 \mathrm{~s} .10 \mathrm{~d}$. This being previous to the war, let us say $£ 150$ now.

In a paper I lear some time ago at the 
Surveyors' Institution on " Vruit-growing as an Auxiliary to Agriculture," I said that "fruit-growing requires a larg("1' working capital than ordinary agriculture. If $£ 10$ per acre is needed for agricultural land, probably $£ 15$ to $£ 20$ will be required for fully-grown fruit trees and bushes on arable land. For new land more capital is necessary, first, to plant the land, secondly, to maintain it till it viclds sufficient to pay expenditure. This latter point is one of great importance, as while in ordinary farming one gets payment during each year for what is grown, in the case of newly-planted fruit trees and bushes one has to wait a considerable time. before a profitable return commences. Strawberries and raspberries are the first lack of which was the great drawback to all ventures, he thought I had somewhat under-estimated this. He found that on plantations in full bearing it took $£ 20$ to $£ 25$ to cover labour, picking, manure, rent. rates and taxes, marketing, interest on capital, and a proportionate amount of capital to be written off each year, and he thought that at least $£ 30$ an acre was required to take a fully-planted fruit farm in full bearing, especially as there was always a chance of one or two successive bad seasons to start with.

"He estimated the cost of planting a mixed plantation (i.e., half standard or standard trees, apples, plums, or cherries, with bush fruit below) at £24 per acre, provided the land was clean, and

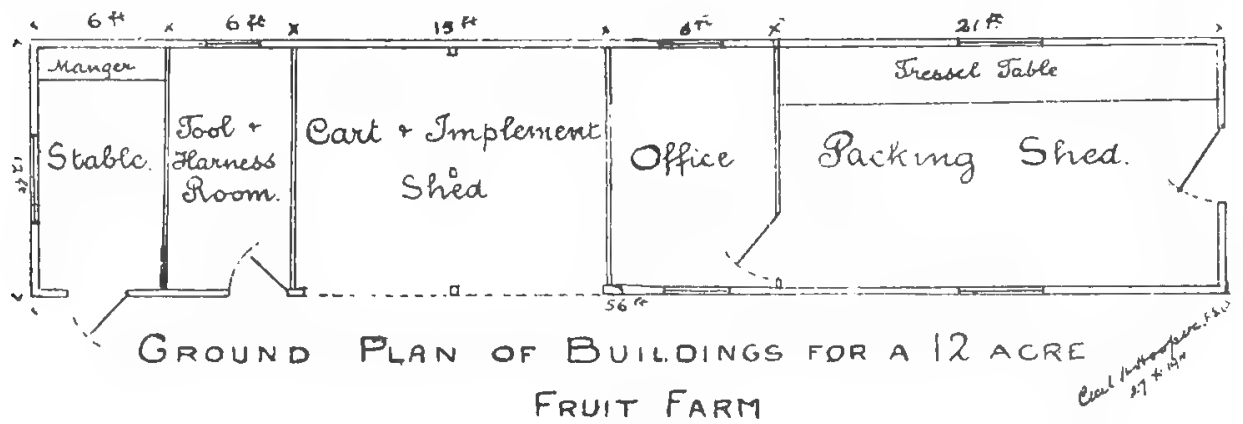

crops that become remunerative, the former in their second year after 1 lanting, the latter in their third. Gooseberries, black and red currants, require four or five years before they vield satisfactorily. Plums, nuts, apples, cherries and pears need longer still; for some of them as much as ten years are required before they can be really called profitable. Hence it is necessary to have capital to meet the expenses of rent, labour, manure, taxes, rates, etc., until the crops return a profit; and it is therefore not advisable to plant too large an area unless there is ample capital."

In the discussion that followed my paper, Mr. C. D. Wise (who for twelve years had managed the Toddington fruit farm of about 1,000 acres estrblished by Lord Sudeley) made a number of interesting remarks on the subject of fruit farming He said: "In reference to capital, rxclusive of the cost of wire netting, which was necessary where hares and rabbits abounded, and also exclusive of anything which might be due for oultivation, corn and cake, etc., to an outgoing tenant. A man who took bare land and planted it with fruit would require at least $£ 80$ per acre for capital.

"He would never advise persons, if they could help it, to plant fruit with borrowed capital: the interest would hang like a load round the neck of the business. It was much better to begin by planting a small area and to feel one's way gradually

"Fruit wrowing was a business and a science, and it was only by experience, and in many cases by loss of capital, that men who embarked rashly in the business found this out. As in the case of all trades an apprenticeship must be gone through.

"A tenant could only hope for success 
on selected areas, where soil and situation were favourable, near a railway station, and with security of tenure-say, a lease of at least 30 years - with a distinct understanding as to compensation at the end of the tenancy.

"Given capital, a landlord who would find the trees, some knowledge of the business and a favourable spot on which to commence, there was no doubt that many a tenant farmer might augment his income by planting a small acreage of fruit to commence with, and, by gradually feeling his way, might establish a good business. The landlord would be increasing the value of his estate, and the labourer would find a greater inducement to remain on the land."

Again, when preparing a paper on "Compensation for Fruit Planting," to read before the Surveyors' Institute, Mr. Walter Kruse, of Truro, Cornwall, most kindly wrote to me on the subject of the cost of raising a plantation of fruit. "In my opinion the cost of raising a plantation of fruit has been vastly under-estimated. The estimates may be very well on paper, but do not work out in practice. It is all very well to put down the cost of trees and planting the ground, etc., but nothing is allowed for contingencies which always occur and there are a great many expenses not included. Nothing is allowed for fencing, gates, fruit lodges, making roads into the plantations, broken trees, re-grafting varieties which prove unsuitable, or for that which is much the greatest item-the cost of cultivation until profitable, together with tithes, taxes, etc.

" I have planted several farms in Kent. and I will give the cost of the second of these which I planted. It was a farm of 28 acres, the whole of which I planted with fruit (except, of course, the land occupied by the house, yard and buildings).

"The cost of planting and cultivation the first two years, after deducting the amount of fruit, potatoes, etc., sold, was $£ 2,070$. Besides this, there was an outlay of $£ 90$ for tencing, and $£ 140$ for fruit lodges, cart lodges, etc. This makes a total of $£ 2,300$, and with loss on cultivation a little longer until the fruit trees paid expenses, came to about $£ 2,888$ or fully $£ 100$ per acre. My subsequent experience in planting confirms this sum. If worked out on the actual net acreage, after deducting rates, etc., the cost would be higher. I went to work as cheaply as I could and grew strawberries to bring a quick return, as my name was known in several markets for sending the best strawberries to those markets, I got very good prices, so I doubt if anyone could do it for less money.

"The reason the cost of planting is usually under-estimated is, I think, because the expenses of cultivation are mixed with those of other crops, and farmers do not keep a separate account of them."

Estimate of Cost of Planting, by Mr. Walter Kruse :-

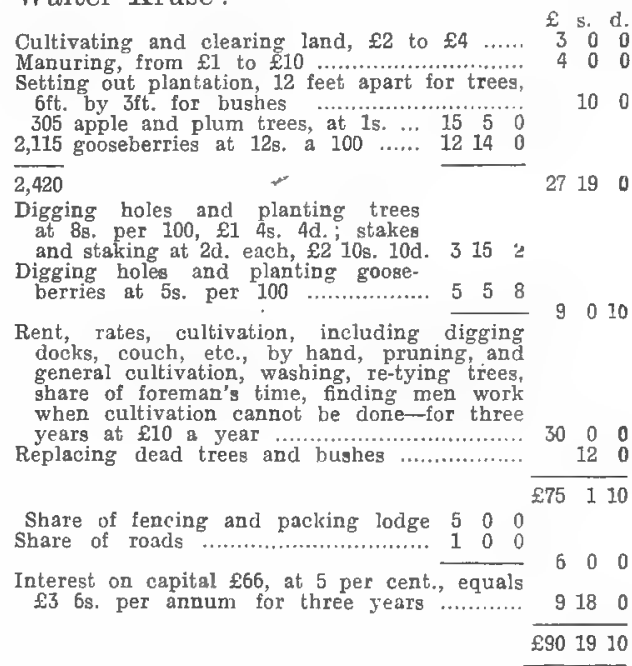

I have quoted Mr. Wise and Mr. Kruse at length, because of their wide experience, and because they expressed their opinion in a very lucid manner. My experience coincides with what they said, but is on a smaller scale.

Owing to the vastly changed conditions of labour and all else, the prices and figures quoted can only be taken as referring fairly approximately to things as they were before the war. At the present time it is almost impossible to offer any reliable estimate, but it is fairly safe to predict prices and cost will never again come within 50 per cent. of those before the war. See also Appendix notes. 


\section{CHAPTER III.}

\section{ON THE SELECTION OF A FARM FOR FRUIT GROWING.}

There are many points to be considered in taking a farm; one will probably not get everything satisfactory in any farm, but it is essential to strive to get as many details promising success as possible. Suitable land is necossary in a convenient locality and at a reasonable price, if purchased; if rentel one wants it at a fair rent, with a reasonable landlord, and, if possible, one who takes interest in the venture.

There are undoubtedly many advantages in ownership of land for fruit farming. It, however, necessitates double the amount of capital, so that in most cases a tenancy is preferable when all things are considered.

The land should be fertile, preferably a somewhat deep soil and one that is kindly to work, otherwise one has to spend an undue amount of money "in muscle and manure" in order to get good crops.

As to situation, some growers favour moderately high land, if not too much wind swept, and a great point is to choos land as little exposed as possible to the danger of injury by spring frosts. The fertile fruit-growing district around Wisbech, although flat and low-lying, is nevertheless little liable to damage by frost, apparently due to the sea air. In this immunity it resembles the famous apple orchards of the Annapolis and Cornwallis ralley of Nora icotia, which is near the sea, yet sheltered from it by a range of hills. Local observation is therefore necessary, together with the experience of those who live in the district. One can point out on the map the districts that have proved themselves the most successful fruit growing parts of Britain. Some of these are faroured by soil, as the Kentish rag near Maidstone, the old red sandstone in Herefordshire and the lias clay in Worcestershire. There are many districts where fruit thrives well in gardens, where commercial fruit growing has never been tried, which might be suitable if convenient for the sale of the fruit. In a new district it is necessary to train men to the work and to ascertain what varieties of fruit thrive best before planting extensively.

For soft fruits (strawberries, raspberries, ripe plums and gooseberries), which need to be sent away as soon as gathered, the farm needs to be within, say, 2 miles of a station, or say 10 or 15 miles of a market town. Apples and nuts not needing quick despatch may be grown further from a railway station.

Another consideration is belter; the land should not be too much exposed to strong winds, which cause many apple fruits to fall if there is a gale.

For unplanted land for fruit farming one does not generally want to give nore than $£ 50$ per acre to purchase, or 30 s. per acre to rent. Fruit growing districts usually pay slightly higher wages for labour than agricultural districts, and, for fruit picking. women and children are usually easily got either locally or from neighbouring towns, as the pay is fairly good, the time of year pleasant, and the work, though long, is not too arduous. The amount of labour employed on a fruit farm is probably ten times as great as on an agrieultural farm, and still far more so than on a grass sheep farm of the same size in the same locality, so that fruit farming is a fine industry for employing labour, and is therefore of national advantage.

It is as well to have some ready-planted fruit land on the farm (if it has been well planted and managed), otherwise the waiting period is so long, as some fruit trees, even as bush, do not do the planter much good till they have been six or eight years 
in the land, though currants, gooseberries and raspberries will help when three years planted, or strawberries their second year; vegetables and other crops may be grown between, however, if there is a sale for them. To work fruit land takes a great deal more capital per acre than agricultural land does, requiring, say, £30 per acre for ready-planted land, and to plant trees on arable land will need an outlay of close upon $£ 100$ ver acre, and now, with increased costs, even $£ 150$, before they are remunerative. Fiven strawberries will have cost $£ 35$ or more, if well manured and cultivated, before they begin to bear. The rent of an established orchard may vary from $£ 5$ to $£ 15$ or even more per acre, according to its capacity of money return. The price of fruit on the trees or bushes when sold by auction per acre varies in Kent from about $£ 2$ to $£ 20$ or more for the best, according to crop, variety and locality.*

In renting land it is very desirable to know something of the landlord and his agent. I thin s it may be accepted in general that the best landlords are those whose ancestors have for generations proved themselves fair to their tenants, have realized that ownership has its duties as well as its privileges and who carry out a principle of "live and let live." Times have, however, been hard on many landowners owning agricultural property without any town or other property to help the balance.

Landowners freshly come from business or professions often lack the mutual trust and interest in local affairs that men have who have known the inhabitants from boyhood.

A man generally makes a better landowner than a woman, the latter being apt to look on her landed possessions simply as rent-making machines, taking little or no interest in the welfare either of the property or its people. This is accentuated if she employs her family solicitor to transact her business instead of a land agent who understands agricultural affairs. The former is apt to act in an unmerciful way with a tenant to extract

* In view of the changing conditions through which the industry is now passing, there figures can only be taken as representing comparative values.-Editor, F. F. and V.T.J. the last pound of flesh in the way of rent and neglect necessary repairs, regardless of the permanent welfare of the estate. The cost of an agreement or a lease should not be great and it should be borne equally by landlord and tenant and not charged to the tenant only.

I knew one case of a solicitor who apparently knew nothing of the farm he was letting. In the draft lease, amongst the many clauses and restrictions inserted, was one that "fishing and shooting were reserved to the landlord." Actually a rain water tank was the largest sheet of water on the farm. In this case the prospective tenant, in self-protection, got his own solicitor to look after his interests in the lease. The total result was that he had to pay for the time of both solicitors, and the lease cost the tenant $£ 50$ for a farm of 130 acres. I merely mention this as a warning, as I fully believe there are many landlords who are and would be willing to make equitable arrangements with tenants who intend planting and cultivating fruit.

A liberal spirit is not made by an Act of Parliament, and a niggardly landlord remains so even after the passing of a. Market Gardeners' Compensation Act, or an Agricultural Holdings Act, as it stands at present, as unless the wording of the lease mentions "that the land is let as market garden land or for planting," a landlord is able to refuse any claim for fruit planting. Of course the agreement needs to be fair from both the landlord's and the tenant's side.

It would be hard for a landlord to be compelled to compensate for plantations he did not wish made on his land and which might not necessarily increase its value; and an impecunious landlord might not like to be under the constant snadow of the possibility of a big claim from a tenant for fruit planted; at the same time it is mean to allow a man to improve one's property without having any intention of recouping him for a share in the cost of the improvement. As a matter of fact, in Kent, fruit farmers do not frequently change their holdings, but in most cases continue on the same farm for many years, their sons often surceeding them and sometimes buying the lanid their 
fathers originally reclaimed from the woods forty or fifty years before.

In the Evesham and Pershore district of Worcestershire a system of tenantright has grown up as regards fruit plantations and market-garden crops, which has become practically " the custom of the country," which works out satisfactorily, there being a good demand for ready-planted fruit land. The landlord lets the land and the incoming tenant pays the outgoing tea ant for the "tenantriyht "; but if there were no incoming
Zenant, the landlord would pay the outgoing tenant. This system gave the model for the original Market Gardeners' Compensation Act which has been made retrospective by the last Agricultural Holdings Act.

The Agriculture Act, 1920, legalises the "Evesham Custom " by which a quitting tenant is entitled to compensation for market garden improvements, but only if he can find another tenant willing to take his place and to undertake the liability for compensation. 


\section{ARRANGEMENTS BETWEEN LANDLORD AND TENANT AS TO FRUIT PLANTING IN DIFFERENT COUNTIES.}

DevonshiRe, where an orchard is re. garded as a necessary part of a farm holding, the estate provides the trees and plants them, the tenant giving such assistance as is required. The tenant does all the subsequent tending and is held responsible for the trees. A great part of the work done on the Devonshire estate. consists of the less satisfactory operation of planting up old orchards, which have become very much dilapidated. Wherever the tenant and the circumstances warrant the necessary outlay, a new orchard is laid out to replace the old one. In granting applications for trees, consideration is always given to the character of the tenant. In the majority of cases the tenants tend their trees satisfactorily, but they require a certain amount of teaching and looking after. It is noticeable that nearly all the applications are for good sorts of market apples, and not for cider apples.

Cambridgeshire, around Thorney. Here the practice has been quite different. The orchard was not considered an essential part of a farm, and any planting done has been done entirely by the tenants. The estate supplies the trees and labour at cost price to the tenants if they wish it, and the estate has also encouraged them by giving a certain amount of assistance by demonstration and teaching.

BEDFORDSHIRE. - The small amount of planting that has been done has been for cottagers and growers (not ordinary farmers). With the cottagers the planting has been purely philanthropic. The estate supplies the trees and bushes, plants and tends them. It also removes them whenever it thinks fit. The idea was for the estate to tend the trees for one or two years only, but it has done so for a longer time, as the cottagers are shy of doing anything to them, chiefly through fear of spoiling them, though it is believed a small additional rent would willingly be paid. In a few cases where growers have planted, they have provided the trees and done everything themselves, under an agreement with the estate that on quitting their tenancy their plantations should be valued by an expert and paid for by the estate. No instance has yet occurred of such a tenant having to be compensated. Anything but yearly leases are opposed to the principles of the estate. Each case of proposed planting would be considered on its merits and modifications in the arrangements made if necessary, always preserving the two principles that the tenant should be paid a proper value for what he leaves for the landlord, and that the landlord shall be called upon to pay for no planting for which he has not given his consent.*

Cambridgeshire: Isle of Ely.-The arrangements made between landlords and tenants as to fruit planting vary according to circumstances. Some few tenants will plant small pieces at their own cost and take the risk as to getting compensation, but this is not done to any great extent. In some cases the landlords will provide the trees, bushes, etc., in which case there is usually an agreement that he pays no compensation to the out-going tenant. In other cases, previous to the passing of the Market Gardeners' Act, landlords would agree for the tenant to plant at his own cost, and allow him compensation on leaving. This is now provided for under the said Act, the only condition being that the tenant shall not plant

*Mr. Spencer Pickering, on the Duke of Bedford's estate. 
without the knowledge and consent of the landlord. $\dagger$

A rough estimate of the cost of planting in Hunts., Cambs., and the Isle of Elył:-

120 half standard apples and plums, 18 feet apart at is.

1,090 gooseberries at 6 feet apart ( 2 rows between tree rows and 2 between trees) at 10 s. per 100

Clean, cultivate, manure and plant land

$£$ s. d.

$6 \quad 0 \quad 0$

A pre-war estimate $£ 20 \quad 0 \quad 0$

Donsetshine.-As a rule, in letting a farm which has orchard land attached to it, the tenant is bound to keep the orchard properly stocked with trees, replacing old or useless trees with young ones. In some cases the landlord finds trees, the tenant doing the planting. A tenant would not be likely to plant a new orchard without the consent of the owner. If he did so he could not claim compensation. §

Somersetshine.-In our district fruit planting is principally confined to orchards, and in most agreements tenants have to keep them properly filled, or at any rate to plant a good thriving young tree in the place of any tree that dies or is blown down, properly protecting same and pruning the trees when necessary.\|

At Crewkerne, in Somerset, there is a custom for the tenant to provide both plant and labour and to be paid by valuation at quitting, but I do not think it works well; if the orchard fails the tenant suffers, and if it succeeds, he is rarely satisfied with the sum awarded to him. "T

In Herefordshire, Worcester, Devon, and one or two other counties the most usual arrangement with regard to planting orchards is:-The landlord finds the fruit trees, and, where necessary, the materials required in protecting them from

†Mr. T. B. Grainger, The Tineyards, Ely.

$\pm \mathrm{Mr}$. Street, of Somersham.

$\S \mathrm{Mr}$. R. Yates, Milton Abbey Office, Blandford, Dorset.

HMr. W. Roberts and Mr. J. E. Tory F.S.I. Yeovil, Somerset.

IMr. Antony R. Cragg. injury from stock, and the tenant finds the labour in planting and in fixing the tree guards.*

A grower in Herefordshire points out the difficulty in the event of the tenant planting as to what proportion of the value of the tree should be attributed to the inherent capabilities of the soil; also he thinks that greater stress should be laid on the nett annual profits, on an average of, say, five or seven years, in making a valuation.

Gloucestershire.-As far as I can gather there is very seldom any compensation paid to tenants for either planting or rearing young trees: it may be done on a very small scale in a few individual cases, but an uncertainty of this kind is almost worse than nothing. In this district landlords usually pay for young trees and for rough fencing, the tenant planting, fencing, etc. : consequently trees are often badly planted and very seldom staked; then they grow badly and are greatly neglected afterwards. In my opinion if we are to hold our own in fruit growing it will be necessary for tenants to receive adequate compensation for nursing young trees, even when landlords find trees and fencing, as apple and pear trees (standards in orchards) are very little use for several years. Consequently most tenants naturally will not carefully nurse young trees, as if they do so it may mean having to pay more rent when the trees become profitable, or leave all behind for another; to use an old expression, I think landlords "stand in their own light" by not allowing adequate compensation to a tenant for planting, fencing and nursing young trees. $\dagger$

I am informed by a prominent firm of land agents in Gloucester that they have no estate agreement between landlord and tenant as to the planting of fruit trees or a scale of compensation in respect of the planting.

So far as their experience goes, the state of things in regard to planting is very unsatisfactory and, they think, in most cases, it would answer the landlord's purpose to bear the whole initial cost - that is

${ }^{*} M$ Ir. A. R. Cragg.

+Mr. T. Herbert Phelps, Tibberton, near Gloncester. 
to say, to plant and fence the trees. The old custom was for the landlord to find trees and the tenant to fence and plant, but everything depends upon the planting and the tenants will not, as a rule, incur the expense of doing this work thoroughly. For instance, every hole when planting in pasture land should be dug 6 feet in diameter and 2 feet deep, otherwise the trees will run the risk of being "root bound." Then, again, the fencing should be done in such a way as not only to protect the trees from the stock, but to insure that the bark of the tree shall not be injured. Too much importance cannot be paid to "mulching" of the trees.

It is absolutely essential that the trees shall be well mulched with manure in the spring, as it will not only feed the young tree, but keep the roots cool. But experience shows that comparatively few tenants will attend to all this-they invariably say, "the trees will not come to full bearing in my time, and why should I have the trouble of looking after them."

It would seem to be almost better to have a separate agreement with respect to newly planted orchards, clearly defining the obligations of the landlord and the tenant, and if the farm be let on lease it might be well to fix the rent on a sliding scale, as it is only fair to remember that for the first few years the tenant would really derive very little profit from the plantation.*

WorcestershrRe.-Mr. Albert Buck, of Worcester, wrote: "I am all in favour of settling terms with a tenant before he plants," and quoted the following example of the difficulty that may arise if this is not done:-

A small farm situate about two miles from here, containing about fifty-four acres, was let for a term of fourteen years from the 29th September, 1885, rent $£ 175$. Of the fifty-four acres about thirty-two were arable. Some time previous to the expiration of the lease the lessee obtained the lessor's consent to plant this arable with fruit trees; the latter did not realise that he was incurring any liability.

"At the time the lease expired the " thirty-two acres was a plantation of * Messrs. Bruton Knowles and Company,
Gloucester. "plums, gooseberries, and currants, just "in full bearing. The lessee claimed the "sum of $£ 10,500$, the amount of compen"sation which, under the Agricultural "Holdings Act, 1883, and the Market "Gardeners" Act, 1895, he was entitled to. "The claim was, no doubt, very exces" sive, but as it was made on the basis " of a valuation by a nurseryman of good " standing here, it would, if contested, " have been an expensive enquiry, and "the lessors had not means to devote to "the purpose. It ended in our selling the "whole property to the lessee for $£ 5,500$, "he foregoing his claim. The year 1899 "was an exceptionally good year for plums "and gooseberries, both as regards "quality and price, and if we had fought "the case I have no doubt $\$ 3,000$ or " $£ 4,000$ may have been recovered; it is "impossible to say what would have been "the result. I wish the lessor had been "able to fight; it would have been a valu" able test case. I fancy there have been "many of the same kind."

Worcestershire: The EveshaM System of Free SALE.-In reply to a question: "What advantage to the landlord is the planting of fruit if there is free sale of tenant right?" Mr. G. New has kindly replied that the advantage to the landlord if the tenant plants trees is that the former is able at the end of the tenancy to get more rent for the land. But if he allows, as is more often the case, the outgoing tenant to sell to the incoming tenant, in the first place he always secures a good substantial tenant and has in addition a considerable security in case rent gets in arrear, by the value of the ingoing. It may also be said that he keeps up the rent which for Evesham land is certainly high.

Mr. G. Jones, of Evesham, also replied to this question:-" The land insures a "good tenant, and if there is a change of "tenancy the incoming tenants will often " pay a slight increase of rent voluntarily. "Take this case, for instance. Lady "Northwich had a farm which, as a "farm, let at 10s. per acre, it was cut up " into thirty tenancies. Rent started at " $£ 1$ to $£ 2$ per acre, tenants commenced to "plant and the whole farm became fruit "plantations; it was then offered for sale "for the purchaser to compensate the 
"tenants. The tenants called a meeting, " and I valued for them. The amount due "to tenants was about $£ 2,000$, the new "landlurcl was invited to meet the tenants, " and in a good spirit, said he would sell "to each tenant his holding at a nominal "profit on the purchase, or he would let " each tenant go on as before, with a small "increase of rent. The latter alternative "was accepted by all. The landlord gave " a written agreement that if any tenant "wanted to leave they were to give him "the first offer of the tenancy, and he "would be willing to pay the same as any " other incoming tenant. This, of course, "gave general satisfaction and the new " landlord got a good interest for his pur" chase. I can hardly see what the land"lord wants more than this, for he is not "entitled to what his tenants have "laboured for years for. If the land is " required for buildings or any other im"portant matter, it can be sold at a price "that the landlord can afford to pay his "tenant, especially now that the scale of "charges is well known."

WARWICKSHIRE. - With regard to any definite arrangement between landlord and tenant in this county, there is none; they vary in different parts.

In one case the landlord finds trees and plants the same, the tenant pays 5 per cent. on the outlay, and no compensation at the termination of his tenancy. In another, the landlord finds trees and materials necessary for fencing or protection, the tenant plants and pays all labour in connection with fencing, etc., and undertakes to keep up the number of trees. In this case no compensation is allowed at the end of the tenancy. In another case a tenant who farms a large irea of land wanted to plant fruit trees, which he has done on part of his holding, but the landlord would not agree to allow any compensation at the termination of tenancy, although the tenant found all trees and labour. The landlord would not recognise any part of the farm as market garden land.

In a case where the trees were planted before the Act came into force, a stiff claim for compensation has been made and sustained.*

Mr. Walker Bernard, Stratford-on-Aron.
Kent.- In agent neal Tonbridge says he had to arrange the planting of several large orchards, and in those cases the landlord provided the fruit trees delivered on the site and also paid the wages of the man who superintended the planting, the farmers providing three men to do the labour of planting, etc. In the above cases no compensation would be claimed at quitting. $\dagger$

\section{Scotrand.}

Mr. John Speir, Newton Farm, Newton, near Glasgow, wrote:-" The passing of "the Market Gardeners' Act has been " against the interests of fruit growers " both on farms and market gardens. "Landlords in letting land now do so only " as farm land, and for the purchase of " growing farm crops, even although it " should already be a market garden. This "prevents any fruit of other permanent " market garden crops being planted (or " at least claimed for at the expiry of the "lease), other than the half acre allowed " by the Agricultural Holdings Act. No "landlords provide trees or come under "any obligations to take over any planted "land."

\section{IRELAND.}

In IRELAND no arrangement is entered into between landlord and tenant as regards ownership of fruit plantations. To put it broadly, owing to the dual ownership brought about by the Land Acts, the landlord has really got nothing but a life interest in the land. As long as the landlord receives his rent he is powerless and the tenant can erect what buildings he likes, make what plantations he likes and when he likes sell his ownership in the farm, the landlord exercising a nominal approval of the new tenant. In nearly every case all buildings, fruit plantations and the like, belong to the tenant, and certain families have held their farms from generation to generation. This causes one of the difficulties under which Ireland is now labouring, namely, to determine what belongs to the landlord, what to the tenant. It is, however, taken as a rule, that when land is surrendered to the landlord the tenant is entitled to compensa-

†Mr. Antony R. Cragg. Estate Office, Grattul Park, Surrey. 
tion for all he has put on the land; in other words, the landlord has to buy his interest. The same holds good in the case of a farm that has been taken over from the landlord with standing buildings and orchards. When the tenant leaves he is either entitled to compensation for his trees or to take them with him. $\dagger$

BASIS FOR COMPENSATION.-Mr. J. $K$. Woodward, fruit farmer, Worcestershire, wrote:- "That the landlord should "receive some recognition of the inherent "capabilities of the soil I am willing to " admit, and as it seems probable now that " the law on the matter will be based on " obtaining the landlord's permission in " writing, I suggest that the proposed site " be previously inspected, valued, and "terms of future tenancy be arranged "beforehand; and not that the landlord "step in and take 25 per cent. if the " orchard be a splendid success owing to "careful selection, planting and cultiva" tion by the grower. That would be a tax

†Captain R. Berry, Green Castle, Co. Lonegar. "on the industry, and it must be noted " that, unlike a house, a fruit plantation " in fifty years will be declining in value, "and should the forty or fifty trees per "acre equal 'not far short of $£ 1$ each,' "the $£ 40$ or $£ 50$ per acre is a fair price "for freehold originally, and represents " $£ 1$ per acre per annum for fifty years. "So that, considering the initial outlay at "£1 per acre per annum and the original "rent at 30s. per acre, an additional $7 \frac{1}{2}$ "or 10 per cent. for permission to plant "should recompense the landlord amply." "I know by experience that where the "plantation is on land belonging to a well " and old-established family, whose rental "is a fixture, the tenant right of such is " of much greater value than on land that " may come into the market in a few years, " or the present rent of which cannot be " relied upon as that which an incoming "tenant would have to pay in the future." Mr. Woodward criticised the cost of actual planting in estimates of cost of planting given as being too low. 


\section{CHAPTER V.}

\section{THE LAW IN RELATION TO FRUIT FARMS AND MARKET GARDENS.}

By Aubrey J. Spencer, Barrister-at-Law.

Author of "Dixon's Law of the Farm."

\section{Fruit Trees and Fruit Bushes.}

The relations of landlord and tenant in respect of rights of cultivation and compensation for improvements are now governed by certain Acts of Parliament passed in 1908, 1913 and 1914, known as the Agricultural Holdings Acts, 1908 to 1914 . Under the Act of 1908 , Section 26, a tenant is at liberty to crop the arable land on his holding as he thinks fit and to dispose of the produce without incurring any penalty, forfeiture or liability, notwithstanding any custom of the country or any provisions of any contract of tenancy or agreement to the contrary. But it is provided that he must not exercise his rights under this section so as to injure or deteriorate tbe holding. If he does $s o$ he will be liable for damages in respect of such injury or deterioration. This provision extends to the arable land of the holding only, but in a case of Meux v. Cobley (61 L. S Ch. 449; [1892] $2 \mathrm{Cb}$. 253) it was held that the conversion of arable or pasture land into a market garden and the erection of glass-houses thereon did not constitute a breach of a covenant to cultivate the farm "in a good and husbandlike manner according to the best rules of husbandry practised in the neighbourhood." It is clear therefore that the law does not prevent a tenant from planting fruit trees or bushes on bis holding and converting it, as to the arable land, in whole or in part into a market garden, even though he may have taken it as ordinary agricultural land, and he need not obtain his landlord's consent to do so.

The question, however, which will seem most important to a tenant proposing to take up fruit growing or market gardening is how far be will be able on the termination of his tenancy to obtain compensation for the improvements he may have made by planting fruit trees and fruit bushes.

The making of gardens and planting of orchards and fruit bushes are improvements mentioned in Part I of the First Schedule to the Act of 1908, and if before making such improvements the tenant is able to obtain the written consent of the landlord thereto he will be entitled at the determination of his tenancy on quitting his holding to obtain as compensation from the landlord such sum as fairly represents the value of the improvement to an incoming tenant, such value in case of dispute being ascertained by arbitration. The consent may be general and given by the terms of the lease under which the tenant holds. In Mears v. Callender $(70$ L. J. Ch. 621; [1901] 2 Ch. 388) the lease permitted a tenant "at his own cost to convert into an orchard meadow land surrounding the house as he might think proper" and it was held that this amounted to a consent in writing by the landlord to the planting of fruit trees which gave the tenant the right $t$, compensation at the end of his tenancy for trees so planted.

In other cases where no specific consent in writing has been obtained to the planting of fruit trees or fruit bushes, a tenant whose tenancy has commenced since the 1st January, 1896 , is by no means in as favourable a position as one who still holds under a tenancy current at that date. The Act of 1908 by Section 42 provides that in the case of a tenancy commencing after that date the tenant will only be entitled at the end of his tenancy to compensation for the improvements mentioned in the Third Schedule to the Act which includes :-

(1) Planting of standard or other fruit trees permanently set sut;

(2) Planting of fruit bushes permanently set out;

(3) Planting of strawberry plants;

(4) Planting of asparagus, rhubarb and other vegetable crops which continue productive for two or more years ; 
(5) Erection or enlargement of buildings for the purpose of the trade or busines. of a market gardener ;

if it is "agreed by an agreement in writing made on or after the 1 st da" of January, 1890 , that the holding shall be let or treated as a market garden."

If it is ont so agreed and the land is let to him nominally as ordinary agricultural land and not as a fruit farm or market garden be will have no such right, even though it may, in fact, be cultivated for fruit or market garden crops.

The result is that a tenant cannot prudently expend capital in making such permanent improvements as the planting of fruit trees or fruit bushes unless (1) previously to doing so he has obtained the written consent of bis landlord, or (2) the treating of the land as d fruit farm or market garden has been expressly recognised by his lease or tenancy agreement, or (3) he has obtained a lease of such length as will enable him to recoup himself for his expenditure by taking the produce of his planting over a considerable number of years.

If he can obtain a clause in his lease or tenancy agreement as follows:-"It is hereby agreed and declared that the lands hereby demised wre let and may be treated as a market garden," he will be in a safe position, or it will probably suffice it the lands let are described as a market garden in the lease or agreement.

A tenant holding under a tenancy current on Ist January, 1896, is, as above mentioned, in a more favourable position, for in such case if the holding was then in use or cultivation as a market garden with the knowledge of the landlord, the tenant is entitled to compensation as if it had been agreed in writing after that date that the holding should be let or treated as a market garden. There are, however, probably now few tenants who are in this fortunate position.

Supposing a tenant has planted fruit trees and fruit bushes and he is not entitled to compensation under the law as above stated, the question may be asked whether he may, on quitting, remove fruit trees and fruit bushes planted by him. The answer is "No," unless it is so expressly provided by his lease or tenancy agreement. The principle of law apulicable to such a case is embodied in th: legal maxim "Quicquid plantatur solo, solo cedit," that is to say, any permanent additions to the land belong to the laudlord (subject to exceptions in regard to "fixtures," to be hereinafter stated) and the tenant must leave his fruit trees and fruit bushes permanently set out for the benefit of his landlord.

\section{II.-Compensation for Manures, etc.}

The Agricultural Holdings Act, 1908, gives a teuant on quitting his holding at the determination of his tenancy (notwithstanding any agreement to the contrary) an unimpeachable right to compensation for improve. ments to the holding by the application of fertilisers and manures, whether the consent of the landlord has been obtained to such application or not. This right extends to all the items mentioned in Part III of the First Schedule to the Act which includes (amongst other things) chalking of land, liming of land, marling of land, application to land of pur. chased artificial or other purchased manure, consumption on the holding by cattle, sheep or pigs, or by horses, (other than those regularly employed on the holding) of corn, cake or other feeding stuff not produced on the holding, and consumption on the holding by cattle, sheep or pigs, or by horses, (other than those regularly employed on the holding) of ccrn proved by satisfactory evidence to have been produced and consumed on the holding. The list also includes and gives the tenant a right to compensation for repairs to buildings being necessary for the proper cultivation or working of the holding, other than repairs which the tenant is himself under an obligation to execute; but it is provided that the tenant before beginning to execute any such repairs shall give to the landlord notice in writing of his intention, together with particulars of such repairs, and shall not execute the repairs unless the landlord fails to execute them within a reasonable time after receiving such notice.

Notice of any claim by a tenant for compensation under the Act, whether for planting of fruit trees and fruit bushes (where he is entitled to make such claim) or for any of the matters mentioned in Part III of the First Schedule, must be given to the landlord before the determination of the tenancy and should usually be in writing, though it does not appear that writing is essential. 


\section{III.-Fixtures axd Bdildings.}

Fixtures include anything annexed to the freehold in a permanent manner, and the law formerly was that the tenant could not remove anything fixed to the freehold without committing waste, for which he would be liable to his landlord.

The tenant was, bowever, allowed to remove fixtures put up for the ornament of the premises or convenience of his occupation; such fixtures are called "tenant's fixtures" and include such articles as stoves, grates, haugings, cupboards, etc. They must, however, be but slightly fixed and be capable of being moved entire. Fixtures erected for the purpu'ses of trade have also been excepted from the general rule, but the exception was not extended to fixtures put up for agricultural purposes. See the case of Elves v. Mat [1802] (3 East, 38); in that case the fixtures were a beast.house, a carpenter's shop, a fuelhouse, a cart-house, a pump house and fold. yard. Machinery, however, and even buildings may be so erected as not to be let into the soil or annexed to it or to any building in such a manner as to become part of the freehold or to lose their chattel character. See Woodfall's "Landlord and Tenant " (19th pdition), p. 740 . In Neurs v. Callentler (70 L. J. Ch. 621; [1901] 2 (b. 388) it was held that glass houses erected for the purpose of his trade by a tenant carrying on the business of a market gardener do not come under the rule laid down in Elwes $\nabla$. INaw as to agricultural fixtures and may be removed by the tel ant during his tenancy apart frnm the privisions of Section 21 of the Agricultural Holdings Act, 1908, hereinafter meutioned.

An agricultural tenant's right to fixtures has now been improved hy Sfetion 21 of that Act. That section provides that any engine, macbinery, fencing or other fixtures affixed to an agricultural bolding (which includes a holding cultivated in whole or in part as a market garden) by a tenant and any building erected by him thereon for which he is not under the Act or otherwise entitled to compensation and which is not so afixed or erected in pursuance of some fixture or building belonging to the landlord shall be the property of and removable by the tenant before or within a reasonable time after the determination of the tenancy. But the tenant right is subject to the following provisions:-
(1) Before the removal of the fixture or building he must pay all rent owing by bim and perform or satisfy all other his obligations to the landlord in respect of the holding;

(2) In the removal of the fixtnre or building be must not do any avoidable damage to any other building or other part of the holding;

(3) Immediately after the removal he must make good all damage occasioned to any other building or other part of the holding by the removal;

(4) He must give one month's previous notice in writing to the landlord of his intention to remove the fixture or building;

(5) At any time before the expiration of the notice of removal the landlord, by notice in writing. may elect to purchase any fixture or building comprised in the notice of removal, and any fixture or building thus elected to be purchased must be left by the tenant and will become the property of the landlord, who must pay to the tenant the fair value thereof to an incoming tenant, such value in case of difference to be settled by arbitration.

The provisions of this section apply tn a fixt ure or building acquired since 1st December, 1900 , by a tenant in like manner as they apply to a fixture or building affixed or erected by a tenant, but do not apply to any fixture or building erected before the 1st January, 1884.

This section applies to all agricultural and market garden holdings ualess the tenant is expressly deprived of the benefits of it by his lease or tenancy agreement.

$$
\text { IT.-RATes. }
$$

The Agricultural Rates Act, 1896, provides that the occupier of agricultural land shall be liable in the case of every rate to which the Act applies to pay one-half only of the rate in the pound payable in respect of buildings and other hereditaments. The expression "rate" means a rate the proceeds of which are applicable for public local purposes and "agricultural land" means any land used as arable, meadow or pasture ground only, cottage gardeus exceeding one quarter of an acre, market gurdens, nursery grounds, orch irds or allotments, bur does not include 
land occupied, together with a house, as a park, gardens, other than as aforesaid.

It has been decided that glass houses in or on a market garden, if buildings, must be treated under this Act as buildings and not as agricultural land. See Smith $\nabla$. Richmond (68 L. J. Q. B. 898; [1899] A. C. 448). Under the Public Health Act, 1875, section 211, General District Rates levied by an Urban Authority are assessed upon the occupier of any land used as arable, meadow or pasture ground only, or as woodlands, market garden or nursery grounds in the proportion of one fourth part only of the net annual value thereof, and under Section 230 of the same Act, a similar provision is made in respect of a separate rate for special sanitary expenses levied by a rural authority.

In Purser v. Worthing Local Board of Health [1887] (56 L. J. M. G. 78; 18 Q B. U. 818 ), it was held that a market yardener occupying a piece of land upon which were built green houses or glass houses which practically covered the surface of the land was entitled to the benefit of the above enactment in favour of a market garden or nursery ground. The apparent difference hetween this decision and that in Simith $\nabla$. Richmond is probably due to the fact that the wording of the relevant sections in the Public Health Act, 1875, and the Agricultural Rates Act, 1886, differs, the latter Act drawing a distinction between land and buildings which is not found in the former.

\section{V.-Trespass and Game.}

The law of trespass may in some cases be of importance to the fruit farmer. When the trespasser is not in pursuit of game or doing any appreciable damage to the land or anything upon it, there is no summary and inexpensive remedy at law available. The occupier may, however, order the trespasser off, and may use just sufficient force to expel him. Unlawful and malicious damage t' any plant, root, fruit or vegetible production growing in any garden, orchard, nursery ground, greenhouse or conservatory is junishable on summary conviction before ju-tices by imprisonment not exceeding six montbs or fine not excefding $£ 20$ above the amount of the injury done (Malicious Damage Act, 1861. Section 23), and unlawful and maluious injury to any tree or sbrub to the amount of 1s. at least is punishable in like manner by imprisonment not exceeding three months or fine not exceeding $£ 5$ (Malicious Damage Act, 1861, Section 22). If the damage exceeds $\& 1$ greater penalties are incurred (Malicious Damage Act, 1861. Section 20). Stealing or destroying or damaging with intent to steal any plant, root, fruit or vege table production growing in any garden, orchard, nursery ground or conservatory renders the offender liable on conviction to imprisonment not exceeding six months or fine not exceeding $f 20$ above the value of the article stolen or the amount of the injury done. Any sum of money forfeited on any summary conviction for the value of the property stolen or taken or for the amount of any injury done (such value to be assessed by the convicting justices) is payable to the party aggrieved. (Larceny Act, 1861. Section 106).

\section{Shootinc.}

The tenant of a fruit farm or market garden where the shooting rights are reserved to the landlord is entitled to kill and take ground game ( $i e$, bares and rabbits) on the land, but only the occupier and another person authorised in writing may so kill ground game with firearms, and no person may be authorised by the occupier to kill or take ground game except members of his household resident on the land in his occupation, persons in his ordinary service on the land and any one other person bona fide employed by him for reward in the taking and destruction of ground game.

Spring trapa may not be employed for the purpose of killing ground game exceps in rabbit holes,

The occupier and persons duly anthorised by him are not required to obtain a licence to kill game for the purpose of killing and taking ground game on land in his occupation (Ground Game Act, 1880. Section 4), but there is no exemption in such case from the provisions of the Gun Licence Act, 1870.

An occupier of any land himself using or carrying a gun for the purpose only of scaring birds or killing vermin need not have a gun licence, nor need any person employed by him for it nn purpose if the occupier himself has a licence to kill game or a gun licence. (Gun Licence Act, 1870. Section 7.) 


\section{CHAPTER VI.}

\section{SOIL, SITE AND SHELTER FOR FRUIT PLANTATIONS.}

By Ernest M. Bear, of Magham Down, Hailsham, Sussex.

Anyone who has visited fruit farms in different parts of this country knows that successful plantations are to be found on a fairly wide range of soils and in varying situations. It is fortunate that there is a good deal of latitude in these matters, because the people who have a free hand in selecting a site are few in comparison with those who wish to plant fruit on land they already own or occupy. At the same time, there is no doubt that some soils and aspects are very much better than others for fruit culture. Examine the orchards on what is recognised as good fruit land in Kent or the Evesham district. The young trees have a healthy and vigorous appearance, with plenty of stout new growth and broad, dark green leaves. The older trees are big specimens, with thick stems and shapely heads. Fruit from such orchards is large, clean-skinned and of good colour. For comparison turn to an orchard on thin soil, or where the subsoil is unsuitable. The trees are smaller and weaker looking, the leaves often being narrow and of a yellowish colour, whilst there is ample evidence of canker and other fungus diseases. Inquiry will probably bring out the information that certain classes of fruit cannot be grown at all, whilst, even of those that can, only a few rarieties thrive well enough to be profitable. Inspection of orchards with an eye for such matters is one of the best guides as to the suitability of any particular district for fruit-growing, though it must be borne in mind that soils often vary widely over a small area. The above descriptions of good and bad orchards are, however, cxtremes, and there is no doubt that there is plenty of land that falls short of the ideal which is still quite suitable for commercial fruit culture, and much of that in districts which have not been tried for the purpose.

GOOD AND BAD SOILs.-The ideal land for fruit is composed of deep aliuvial soil overlying a naturally well-drained sub-soil, such as chalk. What are known as "brick earth" soils over the Lower Greensand formation are also amongst the very best for general fruit culture. With these may be bracketed sandy loams $2 \mathrm{ft}$. deep or more, provided that the subsoil is not cold and wet. On land of these classes, if lime is supplied where deficient, all kinds of orchard trees will thrive, whilst bush fruits can be grown to perfection. Going to the other end of the scale, waterlogged land and shallow soils over sand, gravel or chalk should be avoided like poison. Between these extremes there are many soils that will suit most classes of fruit, though they may not do for all. The chief necessity is a good depth of top soil and a subsoil that allows of natural drainage. Neither very heavy nor very light land should be selected; not that they cannot be made to grow good fruit, but because they add difficulty and expense to its production. Clay land is hard to cultivate and expensive to drain, and so cannot be recommended, in spite of the fact that some of the finest apples are grown on heavy land over clay in the Weald of Kent. The chief objection to light, sandy soil is that it dries quickly in summer and is continually in need of added organic matter, which is very expensive nowadays. Still, light soil is probably to be preferred to clay. for, if well manured, it is capable of producing fruit of delicate appearance and choice quality, whilst the trees generally form fruit spurs freely.

It is sometimes said that fruit can be planted with confidence on any land that grows good crops of wheat and roots. This may be a rough guide, but it does not take sufficient account of the subsoil. There is plenty of land that grows farm crops well enough, but fruit trees become unhealthy as soon as their roots penetrate 
to some depth. This is mentioned to emphasise the importance of the subsoil. If it is waterlogged, trouble with canker and other diseases must be expected. Draining improves matters, of course, but it is a poor substitute for a naturally drained subsoil.

S'ELECTION OF S'ITE.-Unfortunately land that is of a suitable character for fruit culture must often be ruled out of court because it is badly situated. Rich, alluvial soils, for instance, are often to be found in low-lying valleys. Planting cannot be recommended in such situations, because they are especially liable to late spring frosts, an enemy against which the grower is practically powerless. Bleak hills are obviously to be avoided, as the plantations would be exposed to strong and cold winds. Moderate altitudes are best, for, whilst not being too much exposed, they generally enjoy a free circulation of air, and consequently are less likely to be visited by late spring frosts, since cold air gravitates to lower levels. A gentle slope towards S. or S.E. is usually considered best. A S.W. aspect is also good, provided that it is not too much exposed to the gales which come from that quarter. Indeed, some prefer S.W. to S.E., because the sun does not strike on the trees so early in the morning, and cause a toorapid thaw when there has been a night irost; and it has been noticed that the bloom sometimes escapes damage in consequence. Slopes to the $\mathrm{E}$. and $\mathrm{N}$. are naturally undesirable, since they are exposed to the coldest winds; yet there are instances of successful plantations with such aspects. Much depends, of course, on the existence of natural shelter from hills, though these must be very near to do much good. There is nothing to be said against a level piece of land, except that it is diffeult to drain, for it is easily sheltered from cold quarters by means of trees planted for the purpose.

SHELTER TREES.-Most fruit plantations need shelter from the $\mathrm{N}$. and $\mathrm{E}$., whence come the coldest winds, and from the S.W., from which quarter we get most of the gales which are the cause of much windfall fruit. If there are already hedges around the plantations, these should be allowed to grow from 10ft. to $20 \mathrm{ft}$, high, being faced up annually to keep them well furnished. In some few cases this may suffice for shelter, particularly if helped by the planting of strong-growing varieties as the outside trees of the plantation. In some districts damsons are used for this purpose, but in most places they do not fruit well enough to pay. In Kent the Bush plum is often employed; and other strong-growing varieties, such as Monarch and Rivers" Early Prolific, are also suitable for the purpose. The Chalk pear, which makes a big tree, is planted for shelter in some orchards.

The reason for using fruit trees in this manner is, of course, that they produce crops as well as providing shelter. The plan is good enough if the plantation consists of dwarf trees, and if the site is not very much exposed; but in most cases something more substantial in the way of shelter trees is required. If fruit trees are to crop well, they must not be too close together, and they must have their branches thinned to some extent, and then they cannot afford much shelter. Another objection is that they do not grow much faster than the trees they are required to screen. Having tried both plans, the writer very much prefers to plant forest trees for shelter if the situation is at all exposed. What is wanted is something that grows faster than the fruit trees to be sheltered and makes a much taller tree, whilst it should be evergreen for preference. Cupressus macrocarpa fulfils these requirements, and it is doubtful if there is anything better for the purpose. It thrives on both light and heavy land, stands trimming, and makes an enormous tree in a very short time. Its only fault is that it is rather liable to blow down unless supported for a few years until it had time to get a firm hold of the ground. In the colder parts of the country, it is said not to be hardy enough to stand severe winters. For such districts the arbor vita may be recommended as a substitute. This is quite hardy and less liable to blow down, whilst it is nearly as quick growing. One or other of these conifers should be planted 10ft. apart close to the hedge, and so separated by the width of the headland from the fruit trees. If still more shelter is required, an outer row of Canadian poplars, planted the same distance apart, but opposite the spaces in the conifer row, may be advised with confidence. This combination makes the ideal shelter, in the 
writer's opinion. If convenient, the poplars may be planted outside the hedge and the conifers inside; then the roots of the former will not get amongst the fruit trees. The poplars are extremely rapid growers and make big trees. They can be pollarded if required. As the cupressus' roots are a nuisance in blocking drains, it is advisable to make cement joints where the drains pass through the shelter belt.

Many other trees are used for shelter in different parts of the country, and the choice naturally depends to some extent on the species that thrive best in any particular district. Beech, hornbeam, larch, Scotch fir and Austrian pine have all been planted for the purpose. None of the trees mentioned encourage any of the insect pests which attack fruit trees, a point of considerable importance.
In very much exposed situations it is a great advantage if shelter trees can bc planted several years in advance of the introduction of the fruit trees, though this is seldom possible. The latter then have the benefit of shelter from the start, and make all the better growth in consequence. Continual exposure to strong wind, such as the prevailing south-wester, has a stunting effect on growth and is often the cause of lop-sided trees. The benefit of shelter can be realised to the full only by those who have grown fruit in an exposed situation. At the same time, it can be carried to excess. As already mentioned, a free circulation of air is desirable to lessen the danger of frost. For this reason a fruit plantation should never be over-sheltered to the extent of causing a stagnant atmosphere. 


\section{CHAPTER VII.}

\section{SOIL CULTIVATION IN FRUIT PLANTATIONS.}

By Ernest M. Bear, of Hailsham, Sussex.

The cultivation of the land under fruit trees and bushes is a matter of importance, particularly whilst the plantation is young. Primarily it is done to keep down weeds, but it also does much to promote the growth and well-being of the trees, provided that the implements do not go deep enough to injure the roots. For several years after the trees have been planted, even if there are rows of bushes between them, most of the work can be done with a horse-drawn cultivator. This implement should be light in build and capable of having its width adjusted so plement and fit several of the flat ones on the rear when necessary.

Some such cultivator as that described above should be set to work as soon as the land is dry enough in spring. If it can work in two directions there will be only a small square of land round each tree and bush to hoe by hand. This cultivation and hand hoeing should be repeated at frequent intervals throughout the spring, summer and autumn. It can hardly be overdone, but it is particularly necessary in late spring and early summer, to form a mulch of fine soil, which does

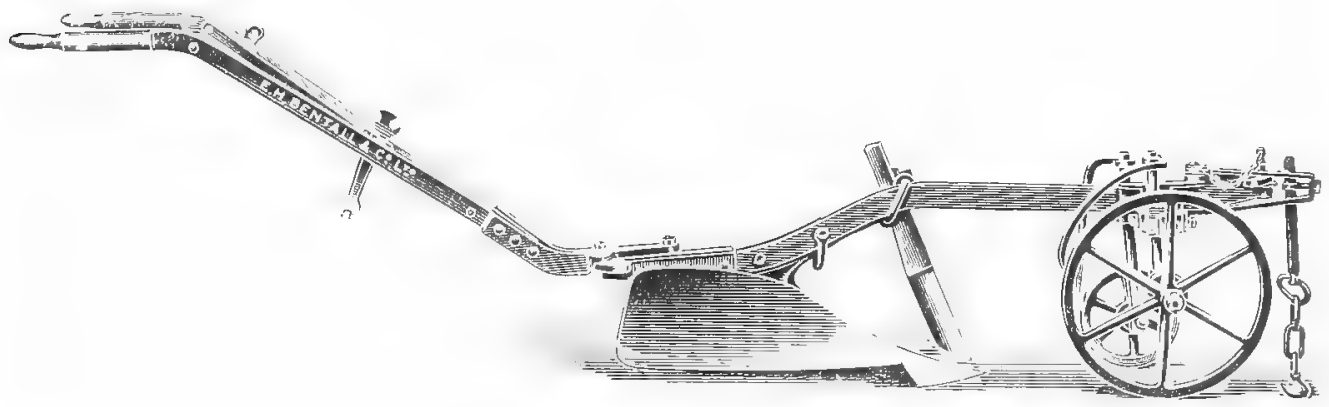

The Fruit Farm Plough (Elevation), designed by W. P. Seabrook and J. B. Udall, made by E. H. Bentall and Co., Maldon, Essex.

that when it passes between the rows it may stir the soil to within a foot of the stems of the trees and bushes. It should have two sets of tines which are interchangeable-straight ones to break up the surface when it is panned down hard, as when the first cultivation is done in early spring, and a set of wide, flat shares to use later in the season when the soil is looser, to cut the weeds more effectually. In practice it is generally found best to keep the straight tines on the front of the im- much to conserve moisture down below by checking its upward flow and evaporation from the surface, and again as far as possible into the autumn, to clear the land of weeds in preparation for winter. After the last autumn cultivation it is a good plan to draw a shallow furrow with a double-breasted plough down the centre of each alley between the rows. This provides surface drainage and tends to prevent the land from lying too wet during winter. 
After a faw years it becomes impossible, in most plantations, to cultivate in more than one direction. This leaves rather more land to be hoed by hand, for there is a narrow strip down each row of trees and bushes which cannot be moved in any other way.

\section{DIGGING.}

The longer cultivation can be done mostly by horsed implements the better for the grower's pocket, but in most plantations this becomes impossible a few years after planting, the cxact time depending on the crops and spacing adopted. Of course, if the plantation were composed of standard or half-standard trees only, horse work could go on indefinitely; but most growers plant bush fruit or dwarf trees between the standards, and then it roots, particularly under plum trees. Before the war, men thoroughly accustomed to this rork in Kent used to undertake it at prices varying from $£ 1$ to $£ 2$ per acre; but few growers in other districts could get it done at that price. Obviously, with wages at their present high level, the operation costs nearly double as much. Thus it is not surprising that growers avoid it where possible. In years when a dry autumn favours late hoeing, so that the plantation is left nicely clean before winter sets in, digging may be omitted, though this often means that the first spring hoeing will be extra hard and expensive. It is seldom that an orchard can be left more than two, or at most three years without digging, if it is to be kept cultivated at all. Even if weeds could be kept under entirely by hoeing,

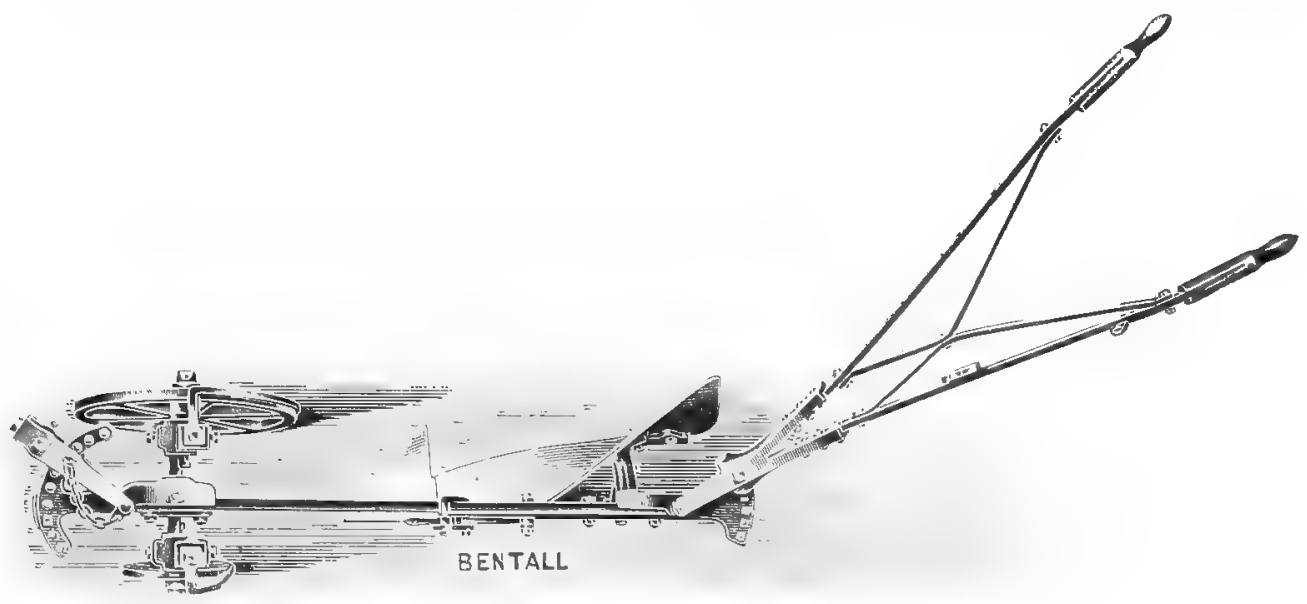

The Fruit Farm Plough (Plan), for Ploughing right up to the butts of Trees.

is not long before growth becomes too dense for horses to be used without doing harm. When this happens there is nothing for it but to hoe the entire surface four or five times during spring, summer and autumn, and dig in winter.

Digging, or rather forking over, is generally done with three-tined hop spuds, the spits being turned over away from the worker. It can hardly be done too shallow, provided that weeds are properly covered. Deep digging injures many digging would still be needed every two or three years to loosen the surface after the trampling associated with pruning, fruit-picking, spraying and other operations, also to cover in manure.

After the bush fruits or other orchard fillers have had their day and been grubbed, leaving only the standard or halfstandard trees, horse cultivation can usually be adopted again, thus doing away with most of the hoeing and digging. Practically the only exception to this is 
the case of plantations composed entirely of bush-trained trees on dwarfing stocks, in which horse cultivation is seldom possible once the trees meet overhead.

\section{Methods of Economy.}

The main object of this article is to suggest methods of economising in land cultivation, the need for which is realized by most growers. Wages are not likely to fall to pre-war standards, though prices of fruit may do so. Growers will therefore be wise to adopt every possible laboursaving device. It appears to the writer that economy must be found under one or other of the following heads:-

(1) Ploughing.

(2) Cover crops.

(3) Grass orchards.

(4) The sod and mulch system.

Ploughing in Orchards.

It is difficult to keep an orchard in good order by the use of the horse cuitivator alone, because, as already mentioned, the land sometimes gets trampled down hard. Moreover, it is desirable to turn in manure. The obvious alternative to digging to overcome these difficulties is ploughing, and a start has already been made in this direction. With the ordinary plough it is impossible to work close up to the stems of the trees, because the overhanging branches get in the way of the horses. There are, however, already on the market at least two ploughs specially designed for this purpose. I am using one of them and am very well pleased with the result. The economy over digging is enormous, weeds are dealt with more effectually, and I think there is less root injury. The special feature of this plough is a simple adjustment of head and handles which enables them to be set at an angle to the beam. This allows the horses and man to walk outside the spread of the branches whilst ploughing right under the trees. The horses (harnessed in line if two are used) are not attached to the head, but by a single chain to a staple on the beam of the plough near the breast. The adjustable head merely guides the chain. In autumn the plough is used so as to turn the furrow-slices towards the stems of the trees, so that an open furrow is left down the centre of the alley between the rows. In spring it can be made to plough the land back towards the centre and away from the trees, but I think that cultivating and hand hoeing will do this sufficiently, obviating the need for a second ploughing. It is possible to plough where the space between rows of trees and bushes is only $6 \mathrm{ft}$., but it does much better work after the bushes have been grubbed and there is a space of $12 \mathrm{ft}$. or more between the rows of trees. A wide, very shallow furrow-slice can then be turned, and the land is not left very far out of the flat.

It will be worth while, I think, to plant orchards with a view to ploughing and horse cultivation. If the trees are halfstandards or full standards no difficulty will be experienced. If bush-trained trees are favoured, they should always have a leg or stem not less than 18in, be given plenty of space between the rows, and pruned so that no low branches extend into the alleys. If no bush fruits were planted between the trees, ploughing could be done from the start, but I doubt if it would pay to omit these. They give a good return whilst the trees are growing to fruiting age-good enough to justify digging for a few years. The horse cultivator, and possibly the plough, may work between the bushes whilst they are young; and it is only when they grow big that digging must be adopted. Then, when the bushes have been grubbed and the permanent trees are in bearing, the plough can be put to its best use.

We still need cultivators with extensions to follow the plough in working under the trees. It is to be hoped, also, that the near future will bring forth a very low cractor for use in orchards. The difficulty with horses is their height.

\section{Cover Crops.}

In America and some, at any rate, of our Colonies, it is the custom to grow cover crops in orchards for the purpose of ploughing them in. The land is thoroughly cultivated during the early summer months, and is sown with a cover crop in late summer or early autumn. The green crop is ploughed under in spring, as soon as the land is dry enough. It is claimed for this system that the orchards thrive 
better than if pormanently under grass or "Non if cultivitiod all the year round. Weeds are suppressed, the soil enriched in humus and so improved in condition, and the washing out of nitrates by the winter rains is prevented. Indeed, if the crop selected is of the leguminous order, the soil is actually enriched in nitrogen gathered from the air. It is found that this system obviates the need for farmyard manule, and this is where the economy lies. Apart from this, the plan viust be expensive, because of the labour involved; and it does not save the usual hoeing and cultivation in spring and early summer. However, it is worthy of a trial in this country, for I have not heard of its buing attempted. It should appeal chiefly nitrogen by growing cover crops. It should be noted, however, that nitrogen and humus are the only plant foods provided in this way, so that the occasional use of phosphatic and potassic fertilisers is necessary.

\section{Giisss ORCHARDS.}

A good many growers have found an easy escape from the expense of cultivating their orchards by letting them fall down to grass and weeds. This plan cannot be supported; but there is less objection to the deliberate sowing of the land with permanent pasture seeds. Sometimes this has the effect of throwing an orchard into fruit when it is making too vigorous growth. It should, however, never be, attempted whilst the trees are young, par-

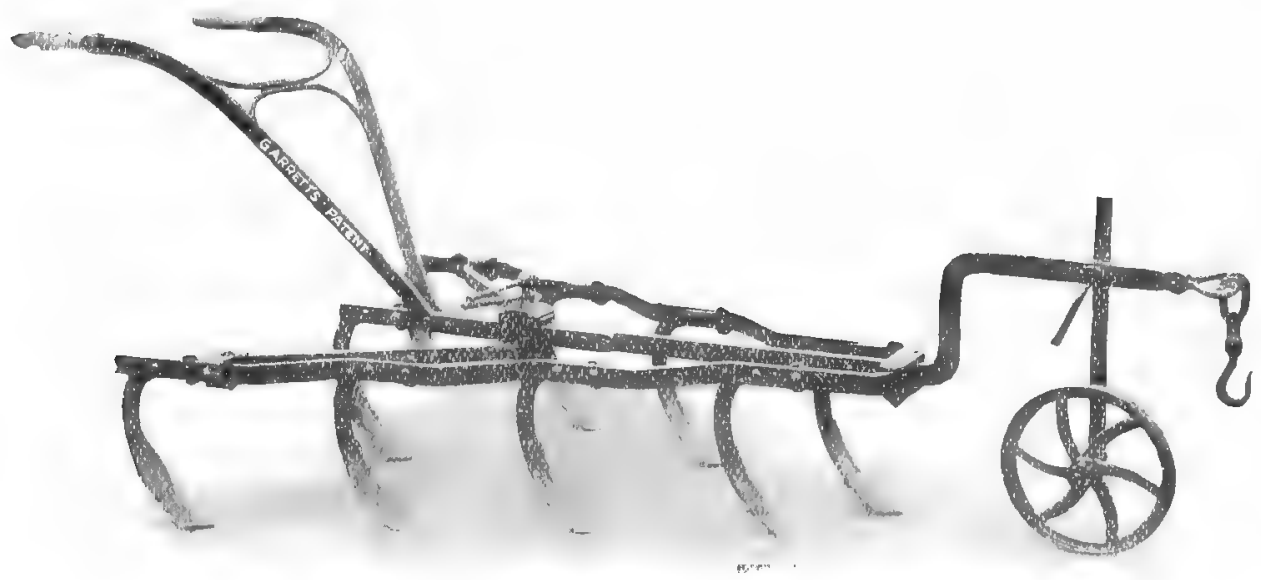

Garrett's Cultivator.-Manufactured by Weeks and Son, Ltd., Maidstone.

to those who have a difficulty in obtaining farmyard or other organic manures. The choice of cover crops is to some extent a local matter, for it is best to select a crop known to do well in the district. Vetches, trifolium and other clovers, sainfoin, mustard, rape and white turnip are all possible, and in America various field peas and beans are used as well. Generally a leguminous subject is to be preferred, on account of the nitrogen it brings to the soil; but if the trees are already growing too much and fruiting too little, these should be avoided in favour of a nonleguminous crop like mustard or turnips, for it is easy to make the soil too rich in ticularly if they are apples, as it has been proved that hardly any treatment has such a stunting effect on young trees as allowing turf to grow close up to the stems. Once the trees are full grown, however, grassing the land often does no harm, as witness many fine grass orchards in Kent and in the West of England. If the trees are standards the herbage can be grazed off by stock and if the animals are receiving cake at the same time the land is improved. In such a case the saving in labour is obvious and the value of the stock is an additional gain. On the other hand, it must be expected that the trees will suffer more during prolonged drought 
than those in cultivated land, whilst it is doubtful if manures can be supplied to such advantage.

\section{The Sod and Mulch System.}

The alternative to grazing a grass orchard, and the only plan possible if the trees are dwarfs, so that stock cannot be introduced, is what is called in America the "Sod-and-mulch System." By this is meant that the herbage is mown twice a year and allowed to lie as a mulch on the surface and decompose there. Obviously a crop of hay should never be taken from an orchard. To do so is bound to impoverish the land and rob the trees. If, on the other hand, we leave the mown grass on the land, nothing is lost to the trees. The plant food contained in the herbage is gradually returned to the soil, together with a certain amount of humus, whilst the mulch of greenstuff serves to keep the surface moist. If a leguminous crop is treated in this way the soil gains in nitrogen as well. I am trying this sodand-mulch system with both grass and lucerne. In both cases this is the fourth year of mowing, and I have no reason to be dissatisfied with the results. The trees look well and bear good crops. Mowing this year cost about 14s. per acre. A onehorse mower cut down between the rows, leaving narrow strips actually in the tree rows to be cut by hand. This work has to be done twice, making the annual cost 28s. per acre. I reckon that the annual cost under cultivation would be three or four times as great. It is not found, however, that the system, even when lucerne is grown, obviates the need for manure. Some of the trees now show the want of it. The chief drawback is the difficulty of getting the second mowing done before the herbage is too far advanced, because the horse mower cannot be used till the crop is gathered, on account of the danger of knocking off fruit. I am not sure that lucerne can be recommended for this purpose. It does not like shade, and is evidently not going to last many years. On some soils it would probably stand better, my land not being such that suits lucerne, even when grown without the disadvantage of trees overhead.

Motor Tractors in Fruit Plantations.

Colonel Clive Murdock, of Linton, near Maidstone, cultivates some 200 acres of fruit plantation with two "Cletrac" caterpillar 25-h.p. engines, made by the Burford Company, U.S.A. Only one horse is kept on this farm; these caterpillar motors haul the produce off the field to two motor lorries, which take the produce to the station. The "Cletrac" costs about $£ 375$.

Pigs as Cultivators.

Many weedy plantations are being cleaned and improved by numerous pigs pasturing, fed with additional food; kept in with wire netting. Their grouting about improves the condition of the land and the trees and bushes. See Appendix. 


\section{CHAPTER VIII.}

\section{THE SETTING OUT OF FRUIT PLANTATIONS AND ORCHARDS.}

Serring OUt by Marker.

Before planting the land should be subsoiled, well worked, and levelled by har. rowing and rolling.

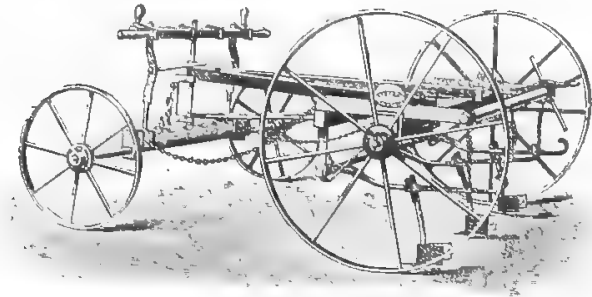

Frutt Plantation Marker.

(made by Messrs. Gibson, of Eynsford, Kent.)

Being given a field to set out, choose the straightest and longest side as the base line, leaving a headland of, say $10 \mathrm{ft}$. or $15 \mathrm{ft}$., for use as a roadway. Set out this first straight line, placing several intermediate stakes; from one end of this set out a line at right angles by means of an offset staff, optical square, or with the chain (right-angled triangle, of 30, 40, and 50 links), and erect a tall stake with a flag at the corner. An implement called a "marker" is then used. This machine is used in the same way as, and somewhat resembles, a corn drill or corn horse hoe, but the tines are weighted so as merely to draw lines on the ground; it is drawn by one horse, and guided by a man and boy. The tines, or coulters, are set to the desired width, so that the lines are very perfectly ruled out if a careful man is in charge. Thus, supposing it is desired to mark out for plums at $16 \frac{1}{\mathrm{ft}}$. apart, goose-
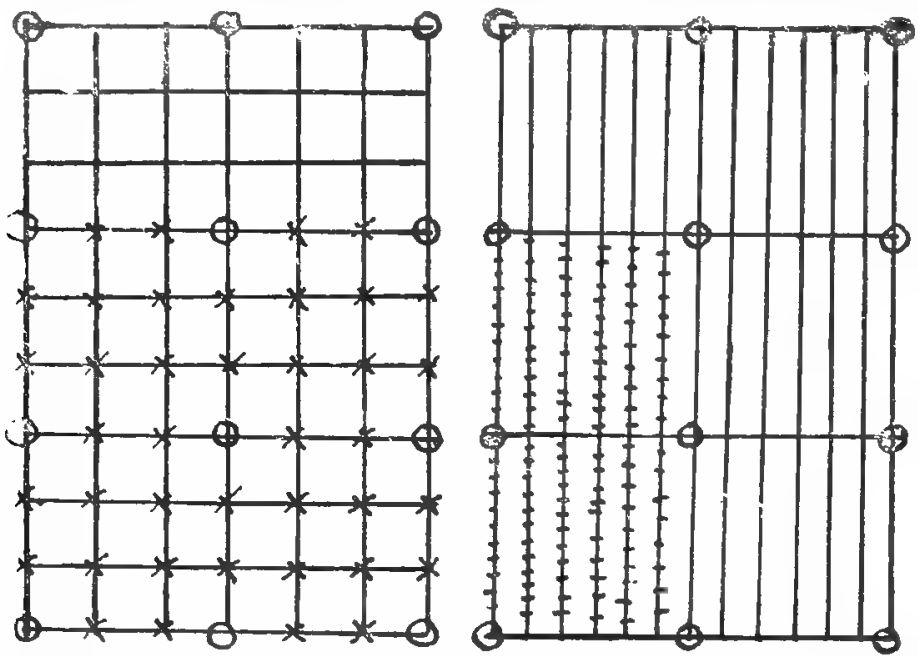

íENTISh Methods of Marking out frutt Plantations

C.H.H.

9 Represents Plums + StrawberrJes

* GOOSEBERRES OR GURRANTS 
berries $5 \frac{1}{2} \mathrm{ft}$. apart, and strawberries, at 33 inches $x 16 \frac{1}{2}$ inches, the coulters should be set 33 inches apart. When the field has been ruled out in one direction it is treated in a similar way at right angles. In this way the position for each tree and bush is cross marked, also the line for the strawberry plants. The above is the method adopted by the larger fruit growers of Kent, who are generally kind enough to lend their markers to their smaller neighbours. This marking machine will rule out about 10 acres a day, and the result is very good. The machine costs about £10. A corn drill can be used for the purpose, but it is not so good.

If the four sides of the field are carefully measured and staked off in distances, the land may be marked out. with the plough for tree planting. Some of the large American orchards are set out in this way with apple trees 30 feet apart. The work is more easily and exactly done if an intermediate sight pole is set a few rods from each end, so that when steering these two poles are kept in line.

Setting OUt by Stakes or Pegs.

If the land is to be set out by stakes, it is most conveniently done by three persons. The four sides are set off at right

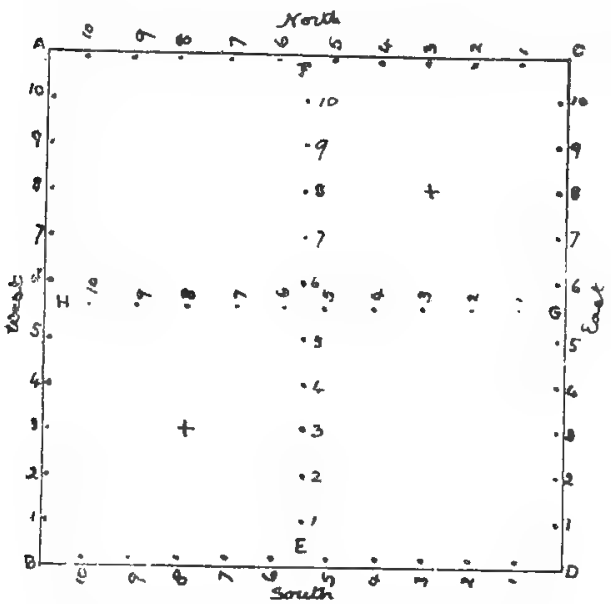

Diagram Showtng One Method of Setting Out an Orchard.

angles, and each side is measured off at the distance the trees are to be apart.
For this purpose building laths make very convenient intermediate stakes, with taller poles with flags at the corners. After the four outside lines have been marked off, set off the other two lines, EF and GH, across the centre of the enclosure, and place laths at the spots where the cross lines cut these.

The diagram is copied from L. H. Bailey's excellent book, "Principles of Fruit Growing." Three men then peg out the stations for the trees. One man (Z) being armed with laths or pegs goes to the stations for the trees, and after having the lath or peg sighted from each direction by $X$ and $Y$, who sight across at right angles to one another, puts in the pegs where he is directed, and the man (X) going alone the line DB, directs the peg-sticker $(\mathrm{Z})$ looking across to the opposite line C.A, past the intermediates on G.H. The third man (Y) goes along BA and looking across to the stations on D.C. and the intermediates on F.E, guides the peg-sticker where to place his pegs, the peg-sticker getting his pegs correct from both directions and so on. To obtain the best result it is advisable to peg out the whole of the land before commencing to dig the holes.

When the land is thus pegged out several parties can work at digging out holes and planting. Before digging the hole it is a good method to use a planting

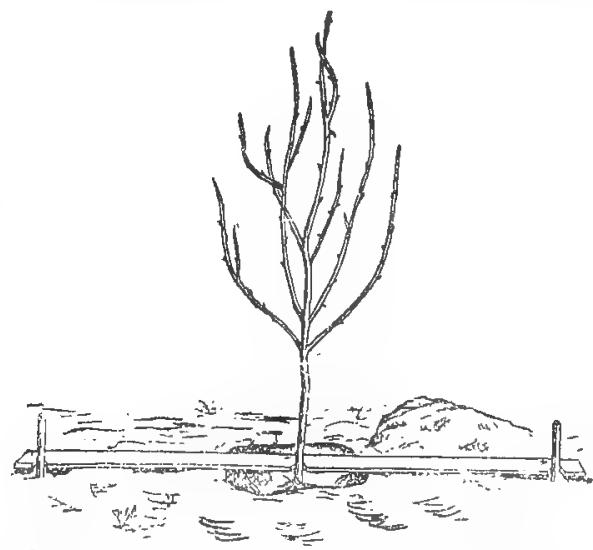

Setting board and Tree in Position.

board, placing the central notch against the peg and inserting pegs at the ends of 
the planting board to keep its position. The board is then taken up, the original peg is removed, the hole dug, and on replacing the board the tree should be placed at the central notch where the original marking peg was.

The following is Professor W. B. Alwood's recommendation as to the method of planting:-Dig out the hole about 2. feet in diameter, removing first
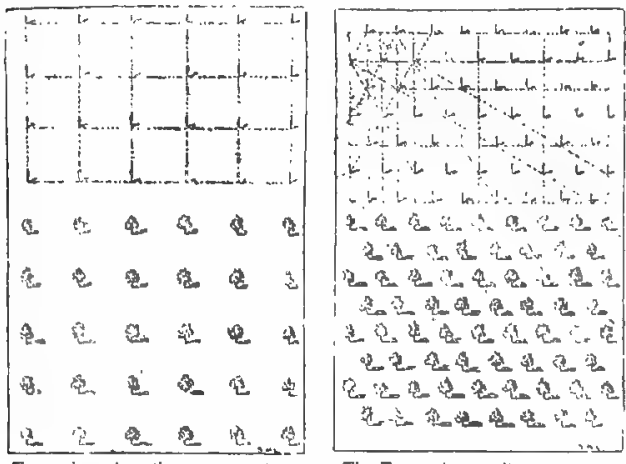

Treen olanted on the square equats

The Truandiar or alternate syacem

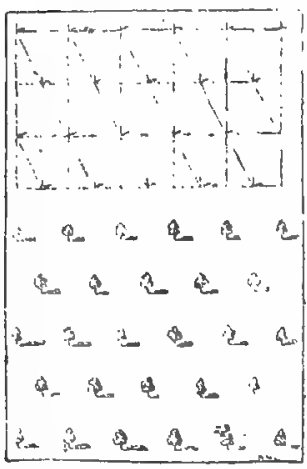

ThE dexagonal or Septuple syatem.

Tays of Laying

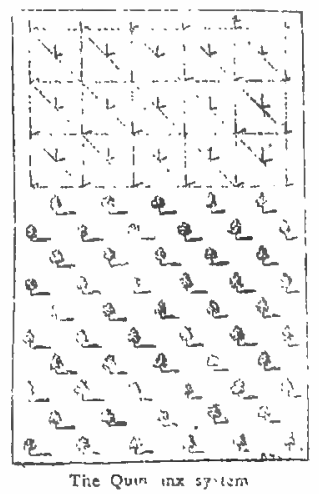

Out Orchards.
From Prof. E. J. Wickson's book " Californian Fruits."

all the surface soil, and place it in a separate heap beside the hole; then remove the subsoil placing it in a heap on the opposite side of the hole. Take the precaution not to place these heaps on a line that will interfere with the replacing of the setting board. The earth should be excavated to a depth of 18 inches, then a strong iron fork is used to loosen several inches deeper. Then the foreman places the setting board over the hole in proper position on the pegs; one of two workmen hands him the tree, which is placed in position. At this point one of the workmen puts into the hole mellow surface soil, as much as may be necessary to bring the tree to the proper depth for planting, so as when completed to be one inch deeper than in the nursery. The foreman arranges the tree, then on his knees places the roots in natural position and distributes fine soil through them as supplied by the workmen; the earth is compacted tightly with the fingers, maintaining the roots separate from each other. As soon as the roots are properly placed and sufficiently compacted to ensure position of the tree, remove the planting board. The foreman continues to hold the tree in position and compact the soil with his feet.

During the filling of the hole care should be taken to lean the tree slightly to the prevailing wind. The hole is entirely filled with best surface soil. The earth may be heaped around the tree an inch or two above the surface level of the field. The tree should be set firmly, with as little free air space as possible. Trees should not be set when the soil is wet, as wet earth compacted against the roots will shrink away from them and leave an air space around the roots.

Planting on the Equilateral Triangle.

This system has the advantage of allowing 15 per cent. more trees on a given area than if planted at the same distance on the square. I once set out a plantation of bush apples, 12 feet apart, on the triangle, by the method I had seen recommended in American fruit growing literature. This method is as follows:-Stake the base line at 12 feet apart, then using two wires with rings at each end (12 feet long, to centres of rings), one places the ring of one wire over a stake on the base line, and does the same with the other wire at the next stake; at the same time another person holds the two rings at the further ends of the wires together and drives a peg in at the meeting point, thus forming an equilateral triangle. The same method is adopted all along the line and then line by line. The result is very good as to accuracy. One of the adrantages claimed 
for it is that one can cultivate in three directions instead of in two as in the square. However, in practice it does not work out nuite as well as it reads, and the thoughtful American has gone back to planting on the square, except, perhaps,

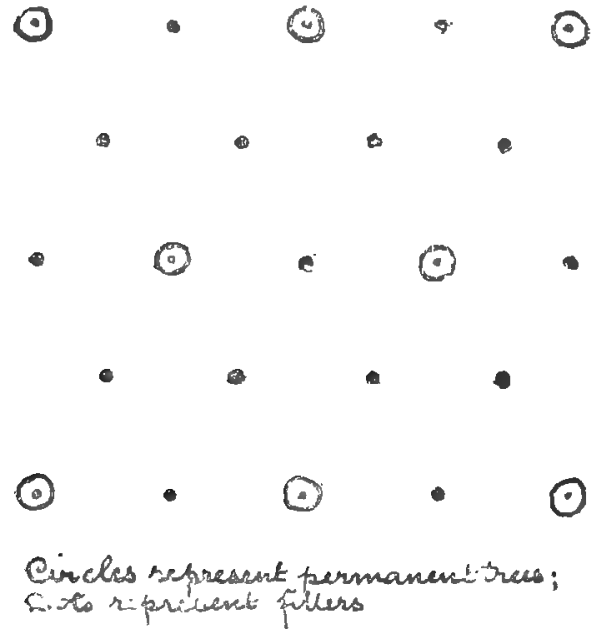

where the plantation is to be thinned. Planting on the triangle is, however, well suited for grass orchards, thus Bramleys may be planted 36ft. apart on the triangle. An ingenious plan of this is given, as under, in "Better Fruit," published at Hood River, Oregon, in the February number for 1912.

\section{INTERPLANTING.}

In the older fruit plantations in Kent it is common to find plums and apples alternating, and in others plums, apples, and cob nuts, the idea being that different trees take up different sized areas, and the land is thus well occupied. There is now a tendency in English and American orchards to interplant alternately strong and weak growing varieties. The following diagram from the bulletin on "Growing the Apple Orchard," is issued by the Virginia Agricultural Experiment Station.

In this case strong growing trees, such as half-standard Bramleys, would be planted as permanent trees, say, 24 feet apart, with weaker growing sorts, such as Stirling Castle and Lane's Prince Albert, as temporary bush trees, 12 feet apart. The temporary would be grubbed up, after, say, 16 years, in order to give the larger space

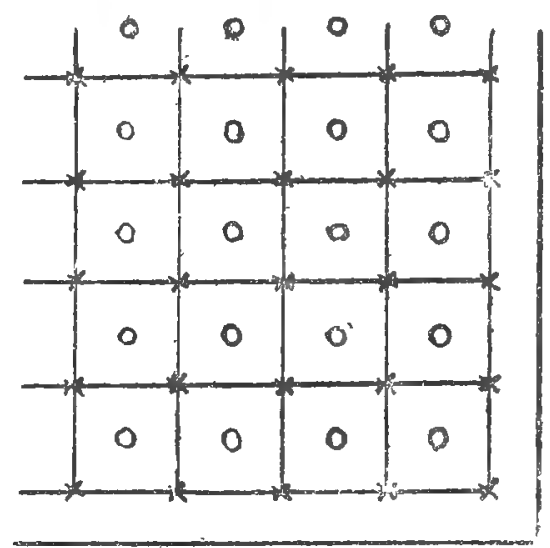

Diagram Showing Metilod of Interplanting Apple Trees.

$\mathrm{X}$ Permanent trees. O Temporary trees.

to the permanent trees. In America attention is being given to planting trees of two or more different varieties in an orchard for cross-pollenation, preferably choosing varieties to place together that are in flower during nearly the same period, early with early flowering, late with late. In the Royal Horticultural Society's "Journal " for December, 1911. F. J. Chittenden, F.L.S., gives a record of the order of flowering of some 224 of the best known varieties of apple. He finds the order of flowering of the different varieties fairly constant year by year, not only in England, but in America and Australia.

Lastly, a record should be made of the varieties and date of planting, either on a plan or in a notebook. One is apt to forget these things, whereas a permanent record is useful in case of change of men, or of a new tenancy, or of a valuation being made and is a great help for ready reference. 


\title{
CHAPTER IX.
}

\section{THE FIELD CULTIVATION OF THE STRAWBERRY.}

\author{
By Cecil H. Hooper and Rowland King Smith.
}

It is a great advantage to plant the runners in August or September, as by so doing the plants have time to form their own roots and get well established before winter. However, this is more easily done in a garden than on a farm, as the fruit farmer is generally very busy with picking other fruits and has not labour at that time to devote to the preparation of land for strawberries. So on a farm it is more usual to clean and dung the land in early winter and plant in February and March.

Steam cultivation is a good preparation for strawberries, or a plough followed by a horse hoe, or, if preferred, a second plough with the mould board removed. The reason for this stirring of the subsoil is that strawberries like to ront straight down and, if checked by the "pan" left by many ploughings, are apt to get root-bound. Deep cultivation previous to planting is recommended for this and other fruits and crops for several reasons: "it increases the water-holding capacity of most soils : admits sunlight and air; extends the root-feeding area; prevents light soils from being blown away; encourages the growth of soil-hacteria; prevents surface washing after heavy rains; and, lastly, enables plants to suc. cessfully withstand long periods of drought."

In some cases, however, deep ploughing is undesirable, as, for example, where soil is very shallow or consists of a cold and heavy clay ; the best results are usually obtained in the cases of deep, uniform sandy loams.

The experience of strawberry growers is that a good dressing of stable or farmyard manure should be applied before planting, and that strawberries do not respond much to guanos or artificial manures used as a top dressing later in their growth.

In former days in Kent, woodland used to be grubbed and planted with strawberries, the latter thriving well on the vegetable mould formed by the decay of the fallen leaves of the trees ; in this case the strawberries needed no manure.
It is very important to have the land clean, well cultivated, and level with a good tilth; the land is rolled and either marked out by a marking machine (something like a corn drill), or marked out with a line, making the ground firm by treading along each side of the line. The runners should be taken from plants only one or two years old, as those from otder plants are weaker. They should also $b+$ only the first or second runner from the plant.

The rows are commonly marked out about 32 inches apart and the plants are placed about 16 inches apart. Latterly, however, many growers are adopting closer planting, "Royal Sovereigns" being frequently planted 15 inches and even 1 foot apart in the rnw. One or two plants are usually put in a hole; sometimes three plants are dibbled in a bunch to make a plantation quickly.

The runners are dug up by fork, trimmed of other runners, or any dead leaves, and tied up in bunches of 25 plants. Oa a farm the strawberries are usually planted in Feb ruary and March. In a garden the trowel is of ten used for taking up and planting, the plants being trodden round to make them quite firm. On a farm, however, the dibble is the planting instrument, with which the plant is also made firm; a careful hoeing follows within a week of the planting.

Many new strawberries appear from time to time and are given a trial by market growers. Up to the present in Kent the two great standard varieties still hold the field, viz., "Royal Sovereign" and "Sir Joseph Paxton." The latter does not grow as it once did (20 or 30 years ago), but nothing has yet been found that combines the cropping power, flavour and keeping properties of this notable strawberry.

If jam is the main consideration, "Stirling Castle" or "Scarlet" are usually chosen. In such districts as that around Swanley, where strawberries have been grown for many years, coarser varieties, such as "Bedfordshire 
Champion," "Favourites," and other varieties, must be grown. In the Channel Islands and at Pershore "Leader" is liked as a good early variety.

Most growers now find it very advisable to cut the blnom off spring-planted strawberries the first year. This costs about 5s. per acre Ic encourages the healthy grnwth of the stonl and saves the labour of picking the few gritty strawberries that would otherwise ripen. Occasionally, but rarely, the grub of the cockchafer beetle nibbles the roots of young strawberries, and has to be searched for and killed; otherwise strawberries are happily more immune from insect pests than aDy other of our small fiuits.

There is, however, one plague that the grower should carefully guard against, viz : "strawberry mildew." Never wait till this appears on the berries, but at the first sign of curl in the leaf apply flowers of sulphur with a knapsack or horse-power machine. Many growers now invariably sulphur once just before the bloom opens and again just before ripening. The job must be done early in the morning while the dew is on the leaves. This sulphuring costs about 5s. 6d. per acre for labour and 25s. for sulphur each time over.

The following gives an idea of the work and cost r.f making a strawberry plantation, also of the annual cost of cultivation previous to the war. The costs, however, keep on rising from day to day. At the present time materials cost double, and the costs of labour and plants is two and a half times as much as before the war :-

Pre-War Cost op One lear Old Strawberry Plantation.

Per acre.

Forking out couch, docks, dande- $£$ s. d.

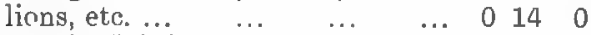
Ploughing $^{*}$ (winter) $\quad \ldots . \quad \ldots .0014$

Three or four harrowings and rolling

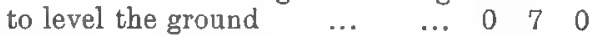

Marking out and planting (March) 1100

Plants, say, 12,000 (at $32 \times 16$ in.) 2150

Ninibbing off blossoms

Hand and horse-hoeing (Nay t,

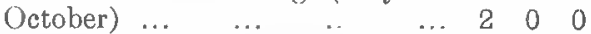

Cutting off ruuners (May to October) $010 \quad 0$

Filling up where plants have died

in May and in September $\quad \ldots .0060$

Digging (November or December) $1 \begin{array}{lll}1 & 4 & 0\end{array}$

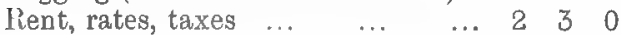

$£ 11 \quad 17 \quad 0$
* If manured, which is almost essential, say with 30 tons dung, previous to ploughing, add $£ 8$ to $£ 10$

\begin{tabular}{|c|c|}
\hline Total & $£ 2017$ \\
\hline & $£ 23 \quad 17$ \\
\hline
\end{tabular}

If with 40 tons per acre

$£ 23 \quad 17 \quad 0$

The profits the first year are nil ; the crop of fruit of, say, five pecks, returns but little more than the cost of its own picking, transport to market and sale, and it is better for the plants to pick off the blossoms.

Pre-War Annual Cost of Cultivating STRAWBerRIYS.

Per acre.

Digging (October) $£ 1$ 2s., or if f s. d. earthing up by mould board plough Horse-hoeing at 3s., hand-hoeing 5 s., three or four times each

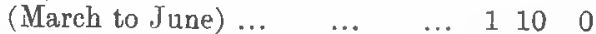

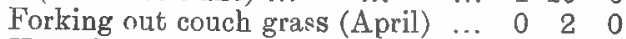

Hand-hoeing when in bloom (June)

One and a half loads of barley. straw at 31s, per load

Carting out and littering straw round plants, spread by men, placed under the leaves by wıurn

Twice sulphuring: Labour 5s. 6d., sulpbur $£ 15$ s.

Picking and packing $1 \frac{1}{2}$ tons fruit, at $4 \mathrm{~d}$. per peck of $12 \mathrm{lbs}$. ...

Carriage $1 \frac{1}{2}$ tons at say 16s. per ton, by road or rail

Market toll and salesmen's charges, 280 pecks at $3 d$. per peck

Cutting off runers after picking (August) $\ldots \quad \ldots \quad \ldots \quad \ldots$

R4king up and clearing off Jitter and runners, costs about 8s., the value of the straw being about the same ............................

Horse-hoeing once ... $\quad \ldots . . .$.

Hand-hoeing once

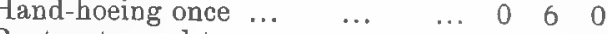

Rent, rates and taxes $\quad \begin{array}{lllll}\text {... } & \ldots & 2 & 3 & 0\end{array}$

Add one-third of first year's cost. say, \&20 10s.

$\begin{array}{lll}6 & 16 & 8\end{array}$

Return, say $1 \frac{1}{2}$ tons strawberries at $₹ 25$ per ton. 28

16

Difference, for superintendence, unforeseen expenses, interest on capital, and profit 
No crop, with the prssible exception of the onion, responds more freely to good and frequent cultivation than the strawberry.

In cultivating the ground in the spring, one-horse or two-horse brakes should be employed, taking care, however, that the latter are not set wide enough to injure the plants.

Formerly strawberries were frequently littered with long stable manure, which to some extent, when washed by rain, nourishes the plantation, but this is apt to make the land weedy from the hay seeds.

The fruit is chiefly picked in Kent in the early morning, from 2.30 or 3 to $630 \mathrm{a.m}$. in time to dispatch by vans with trotting horses, as the trains so frequently deliver the fruit late into market and the fruit is often so roughly handled that growers within 20 miles of London prefer to send by road if they are able. The motor lorry is now largely replacing the horse in marketing strawberries and increasing the radius round our big cities where they can be profitably grown. Whether the aeroplane will now extend this to the whole country remains to be seen.

The subject of "costings," however, is a terror, and last year's control served to show how many side expenses a grower is put to that are apt to be overlooked. For instance, on road-mending, we spent hundreds of pounds in order to keep our soft fruit from getting arred and sbaken and to bring the motors right up to the fields. Then there is the question of wet day employment, housing for pickers, bedding and fuel for pickers, and so on.
The standard package is the peck, though some growers of choice fruit pack in gallons or chips containing 4 or 5 lbs. For Kentish strawberries the price, pre war, at the beginning of the season was usually about $4 \mathrm{~s}$. 6d. per peck, and the season ends with 18. The earliest in market receive the best price; thus similar fruit may sell at 2s. 6 d. per peck at 8.30 a.m., and at 1s. 3d. per peck at $3 \mathrm{p} \mathrm{m}$. ; late delivery into market may halve the return of the grower. The fruit is generally largest the second year after planting, whilst the crop is generally heaviest the third Jear; a fourth crop is taken but the fruit is smaller; after which it is ustrally advisable to plough in the plants and crop the land for five years before replanting, growing such crops as caulitlowers, peas, and potatoes, to give the land a complete change, whilst manuring and cnltivating it well to keep it clean and in good heart.

In the Blairgowrie district of Scotland I understand the yield reaches 2 : tons per acre. The price per ton previous to the war was about $£ 15$ to $£ 25$ per ton, and is now about £60 per ton.

Strawberries are successfully grown on small holdings in Hampshire, also on the banks of the Tamar which divides Cornwall from Devon. Here, on Lord Mount Edgecombe's estate, land faring south suitable for early strawberries lets at 15 per acre, whilst the rent of adjoining land is 20s. This is one of the nnly examples of difference in value I have met due to aspect, but the southerly slope makes the strawberries a fortnight earlier than those of Kent. 
CHAPTER $\mathrm{X}$.

\section{THE FIELD CULTIVATION OF THE RASPBERRY.}

\section{By Cecil H. Hooper and Rowland King Smith.}

In order to be successful with small fruits the soil should be fertile, well situated, clean and well cultivated. A good working soil is a great asset. For raspberries, as for strawberries, gooseberries and currants, the best results are obtained by applying about 30 tons of dung per acre, then ploughing seven inches deep with three or four horses, following each furrow with a heavy brake drawn by two horses to subsoil the ground, stirring it some four or five inches deeper. This is the method followed by some of the best growers; it is almost equivalent to trenching, and costs much less Steam cultivation may be employed to stir the soil if a large area is to be planted.

The raspberry, of all fruits, appears to respond most to heavy manuring. The varieties now most popular for field cultivation in Kent are "Superlative" (introduced by Bunyard), "Hornet"'(introduced by Rivers), and "Bath's Perfection." This last variety, besides being a bright red colour liked by many jam firms, is a good cane producer, and will often succeed where other sorts fail. "Baumforth's Seedling" is a good late variety. Newer sorts include the "Devon" and "Red Cross," both bright red raspberries suitable for bottling. These varieties have replaced "Carter's Prolific" and "Norwich Wonder," the favourites of 20 jears ago. Raspberry, like potato varieties, gradually deteriorate in yield and vigour.

The raspberry is propagated from young plants which come from the parent stool. These young plants should be dug up yearly. The best suckers or "spawn" is that taken from young plantations, as it makes more vigorous growth than that from old plantations. The land to be planted, as already said, should be well cleaned, well manured and deeply cultivated. The tops of the young canes (or spawn) to be planted are cut off about six inches above the ground line to encourage strong growth of young shoots.
A common distance for planting is $4 \mathrm{ft}$. 6iu, between the rows, and $2 \mathrm{ft}$. apart in the row, using one, two, or even three plants to a hole. depending on the strength of the sucker.

Planting is done from November (or as soon as the leaves have fallen) to the end of February, except during frosty weather.

The ronts of suckers to be planted must be duly protected froin frost and drought by carefully bedding them in the soil.

The approximate cost per acre of forming a raspberry plantation, including the first year's cultivation, with everything well done, was in pre-war days somewhat as follows :-

Pre-War Cost Per ACre of Making a Plantation, and First Year's Cultivation.

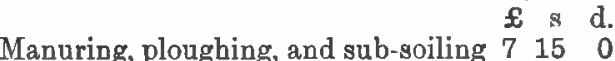
Heading canes and planting in plough

furrow, $4 \mathrm{ft}$. $6 \mathrm{in}$. row, $2 \mathrm{ft}$. apart ... 1 1 00

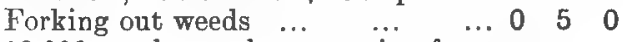
10,000 raspberry plants, costing from $£ 3$ to $£ 10$, according to variety, supply and demand, etc., say $\quad \ldots 5500$ Horse and hand hoeing during $\begin{array}{llllll}\text { summer and autumn } & \ldots & \ldots & 2 & 5 & 0\end{array}$ Cutting out old canes, filling up blanks in late autumn or winter; digging or ploughing and lightly forking between plants in winter; and tipping young canes in March $115 \quad 0$

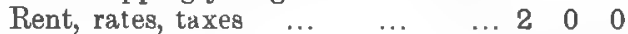

$£ 20 \quad 0 \quad 0$

Note. - Re costings, as with strawberries, compared with pre-war costs, materials cost approximately double, and labour two-anda-half times its previous cost.

As the canes before planting are cut down hard so as to form strong plants, there is hardly any fruit the first summer, and in the second summer after planting the crop is light.

The land is kept clean by horse-hoeing in 
the centres by one and two horse brakes, followed by hand hoeing against the plants.

The cost during the first year is often reduced by growing a crop between the rows, such as early potatoes, which thus shares the cost of cultivation and rent with the raspberries, but also uses up the manure. The annual pre-war cost of cultivating raspberries may be estimated as follows :-

\section{Pre-war Annual Cost of Coltivating} RAspberRIES, PER ACRE.

\& s. d.

(November). Cutting out old canes and thinning new canes ... $\quad \ldots \begin{array}{llll} & 0 & 5 & 0\end{array}$

Tying up the canes cut out ... $\quad \ldots \begin{array}{lllll} & & 0 & 2 & 0\end{array}$ Taking up "spawn" $\quad \ldots \quad \ldots .01000$ Hoeing out between and close to stools $0 \begin{array}{lll}0 & 6 & 0\end{array}$ Manuring (with say 1 ton of wool $\begin{array}{llllllll}\text { waste) } & \ldots & \ldots & \ldots & \ldots & 3 & 5 & 0\end{array}$

Ploughing between rows, 7s.; forking between canes, $7 \mathrm{~s}$. ; (or digging the whole space between the rows by spade, £1 1s. 0d.) ... $\quad \ldots \quad \ldots 014$

(March). Heading canes off at about

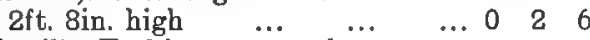

(April). Forking out couch .grass $\ldots \begin{array}{lllll}\ldots & 0 & 2 & 0\end{array}$

(April to October). Horse-hoeing five times ... 015

(April to October). Hand-hooing five times

(July to August). Picking, say, $\dddot{1} \ddot{i}$

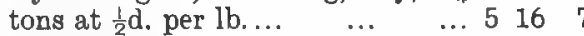

Carriage to market in gallon baskets and tubs, $1 \frac{1}{\alpha}$ tons, at, say, $16 \mathrm{~s}$.

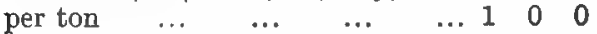

Market toll and salesman's charges

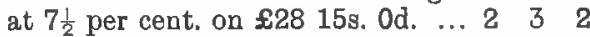
Rent, rates, tithe and taxes... $\quad \ldots 2 \quad 210 \quad 0$

Receipt $1 \frac{1}{4}$ tons at $£ 23$

$\begin{array}{lll}£ 19 & 1 & 3\end{array}$

Balance to cover superintendence, interest on capital for two years (during which there is little return) $\begin{array}{lllll}\text { and profit } \ldots & \ldots & \ldots & £ 9 & 13\end{array}$

NoTE.-Present cost : materials bave risen 100 per cent. quite, and labour rather more than that. The price received for raspberries has increased about three-fold pre-war price.

It will sometimes be found that the young cane of the current year's growth tries to fruit the same autumn. It is not good policy to let this happen. Women should be sent round in late August and September to cut the tips off where the canes are forming blossoms.

The next year's cultivation of the raspberry begins after the picking is finished, the rows are hand-hoed and, as soon as the leaves have fallen, the old canes that have borne fruit are cut out near to the ground line, and the new canes are thinned. These thinnings are tied up with string and stored for the use of the pickers, as fuel for the next year.

The young plants that have been produced at the sides of the parent stool are then dug out. These young plants, or "spawn" as they are called, when taken from young plantations, and of good variety, may yield a good return, but it is not advisable to allow much spawn to grow, as it takes from the strength of the parent plant; therefore it is usual to hoe off and thus destroy most of these shoots during the summer unless specially wanted fur propagation.

In cultivating raspberries it must always be borne in mind that one is dealing with an essentially surface-rooting plant, so whatever digging is done in the rows must be light. Some growers now prefer prong-hoeing to digging, both in autumn and spring.

The plantations are usually dunged once in three years, for which purpose a truck that is narrow enough to run between the rows without injuring them is used; if dung is not used, manure of some kind is probably given each year. Fish salt is good for raspberries; it consists of fish scales and pieces of fish, which, with the salt, is sown broadcast and hoed in. Besides acting as a manure, it helps to keep the soil moist during summer, as salt appears to absorb moisture from the air.

It is advantageous for the soil to be turned over early in winter to allow frost to pulverize it.

After the winter is over, the canes are headed off to a height at which they are sufficiently strong to hold the weight of the fruit without requiring to be stringed.

Between March aud October the land is horse-hoed ; first with a heavy two-horse hoe, then during the rest of the season with a onehorse hoe, the object being to keep down weeds, and keep a good tilth, which enables the soil to keep more moist than when hard and crusty. If in the early part of the year the land is cloddy, a small ribbed or tlat roller is used in the rows, for this purpose narrow ribbed (Cambridge) rollers are manu- 
factured, and are best; failing that a heary garden roller may be used, the horse being attached by chains to the axle, and the roller guided by a man holding the handle and the reins.

Hand-hoeing is also frequently done in order to keep the land clean and encourage rooting.

When the canes are very luxuriant and there is much fruit, it is sometimes advisable to stake the rows and support the canes with cocoa nut string. This, we understand, is a common practice in Scotland, where heavier crops of raspberries are grown than in the South of England. As with the turnip and swede, the further north the better they thrive, so with the raspberry, the cooler climate of Scotland favours the raspberry, almost to its most northern parts, whereas in some seasons in the south of England the raspberry may suffer from drought.

Picking is done chiefly by women and children, some of the latter being excellent pickers, as they can see the fruit near the ground. The truit should not be crushed, and needs light handling.

Nearly all raspberries are picked without strigs, whether for sending away in chip baskets or in tubs for the jam factories. The raspberries are conveyed by van or rail during the njght and delivered to the factory as early as practicable in the morning, as the raspberry quickly ferments when in bulk. A few of the handsomest raspberries are sometimes picked with the strigs into punnets in the early morning for sale the same day. The yield of raspberries per acre in England varies on an average from, say, three-quarters of a ton to two tons. Sometimes in Scotland and New Zealand four tons an acre is reached. The price of raspberries varied considerably, in pre-war days from $£ 20$ to $£ 40$ per ton, according to season and supply.

Raspberries sent to market in chip baskets fetch about 1d. per lb. more than those sent in tubs, but the picking costs more, as they must in this case be picked quite whole and uncrushed; also large quantities are difficult and expensive to handle in this way. In former days the baskets that the Southampton growers had used for their strawberries were afterwards used by the Kentish raspberry growers for their raspberries. The best crops are usually from plantations between three and seven years old ; but plantations last 10 and even 15 years on suitable land. In order to check weeds and at the same time add vegetable matter to the soil, I used to sow turnip seed between the rows shortly before picking time, when a good tilth had been obtained by hoeing; this made a good "cover crop" after picking was over, and gave a useful yield of young turnips.

The raspberry thrives best on a medium light soil, which does not "pan" down tight. It is a shade loving plant naturally, and is therefore a useful undercrop between standard or half standard trees.

PESTS._Of these the raspberry weevil is perhaps the worst. This small beetle lays its eggs in the flower, developing into the maggots so often met with in ripe raspberries. Arsenate of lead has not been found much use; clean cultivation and clearing up of dead canes is the best preventative.

A fungus disease has lately visited some plantations, which has done considerable damage in America. It is called Conicthyrium Fuckelii. This attacks the young shoots in spring and causes them to wilt and die and may need to be carefully watched for. 


\section{CHAPTER XI. \\ GOOSEBERRY, AND RED AND BLACK CURRANT.}

Preparation of Land for Small Fruits.

To be successful with small fruits, the soil must be good, well situated, fertile, clean from weeds, and well cultivated. A good working soil is a great asset. For strawberries, raspberries, and bush fruit on arable land, the best practice consists in applying some 30 tons of dung per acre, or 20 tons with the addition of artificials, then ploughing seven inches deep with three or four horses, following each furrow with a heavy brake drawn by two horses to subsoil the ground, stirring it some four or five inches deeper. This is the method followed by some of the best growers; it is almost equivalent to trenching, and costs much less. Steam cultivation to stir the soil may be employed if a large area is to be planted.

\section{The Gooseberry.}

This fruit used to be regarded as the hardiest and most regular bearer of our fruits, but the advent and spread of

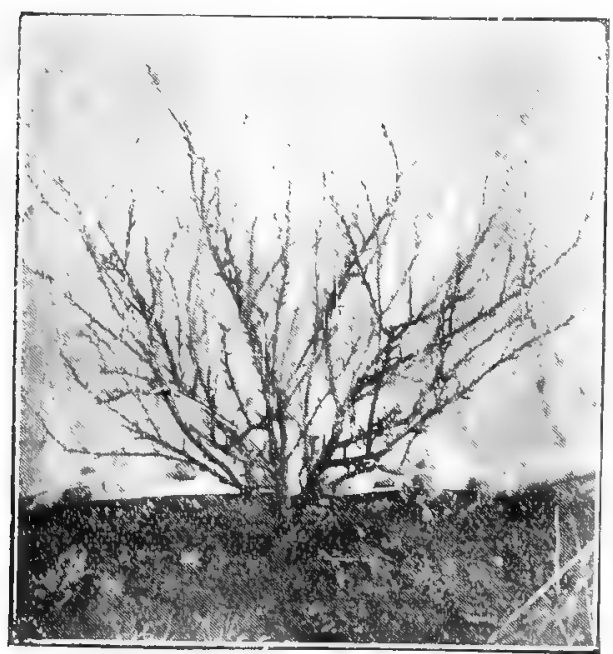

“ Lancashire Lad" Gooseberry. the American gooseberry mildew is a national disaster. Before planting, the land should be well cleaned, dunged, and deeply worked. The bushes are usually planted about $5 \mathrm{ft}$. apart, or, if large growing kinds, on good soil up to $6 \mathrm{ft}$.

Mr. Fred Neame, of Faversham, kindly supplied me with the actual cost per acre of planting four acres, which was as follows:-

\section{Cost Per acre of Planting Gooseberries (Pre-War).}

$\begin{array}{llllllllllll}\text { Ploughing } & \ldots & \ldots & \ldots & \ldots & \ldots & \ldots & \ldots & 1 & 0 & 0\end{array}$

Setting out ground for planting $5 \frac{1}{4} \mathrm{ft}$.

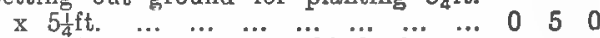
Cost of 1,512 two-year-old bushes at

9s. per 100 with carriage $\quad \ldots \quad \ldots 617 \quad 6$

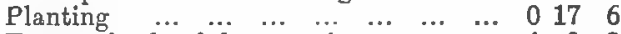
$\begin{array}{lllllllll}\text { Twenty loads of dung at } 4 \mathrm{~s} . & \ldots & \ldots & \ldots & 4 & 4 & 0 & 0\end{array}$

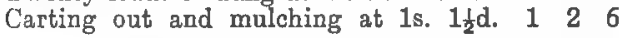

$$
\text { Total cost per acre } \ldots \begin{array}{lll}
\text {... } & \$ 14 \quad 2 & 6
\end{array}
$$

Nore.-At the present time the cost would probably be 130 per cent. more than this.

Mangolds were planted between the rows, and this helped to pay the expenses of summer work. The price of 9s. per 100 for gooseberries was a very moderate one; 12s. was more usual, and sometimes 14s. per 100 for market sorts. The second year's cultivation cost about $£ 4$ per acre, exclusive of rent, including $3 \mathrm{~s}$. for pruning. The crop the second year may be six half-bushels of green gooseberries. Strawberries are frequently grown with gooseberries for the first four or five years.

\section{Annual Cost of Cultivating Gooseberries (Pre-WAR).}

(November to February) Pruning ... 1 s. 5 d.

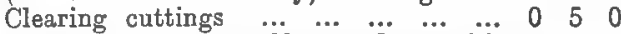
Each alternate year 20 tons dung with cartage, £6 11s. 8d.; wheeling on and spreading, 10s.; $-£ 7$ 1s. $8 \mathrm{~d}$.

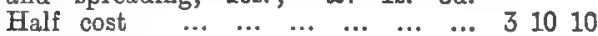


Digging with fork $\quad \ldots \begin{array}{llllllll} & \ldots & \ldots & \ldots & \ldots & 1 & 0 & 0\end{array}$

(April to September) Hand hoeing four times

Picking 2 tons green gooseberries (or $\begin{array}{llllllll}3 & \text { tons ripe) } & \ldots & \ldots & \ldots & \ldots & \ldots & \ldots\end{array}$

Packing 187 half bushels at 2 s. 100

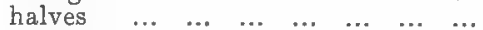

Carriage, 2 tons at $16 \mathrm{~s}$. $\dddot{3}$ tons at $16 \mathrm{~s}$.

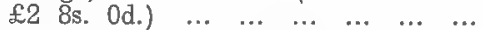

Sale expenses, 4d. per half bushel ...

Rent, rates, and taxes

\section{Cost}

times if the crop is good. Ripe gooseberries are usually picked all at one picking. For picking gooseberries women generally wear gloves.

Green gooseberries travel well, and the package and handling is not troublesome, but ripe gooseberries are very tender, need care in handling, and quick sale. A plantation that will yield two tons green will probably give three tons ripe, but it usually pays best to sell them green; green gooseberries are the first fruit picked when labour is plentiful, whereas the pickers are busy with other fruits when the gooseberries are ripe. The crop in Kent usually varies from about $1 \frac{1}{2}$ up to 3 tons of ripe berries in mature plantations.

It is a point of interest and importance, the fact that certain varieties of certain fruits are specially liable to attack by certain insects. I remember Captain Best, when showing me his extremely wellmanaged fruit farm at Suckley, in Worcestershire, told me he found that a variety of gooseberry called "Rifleman" (I think it was) was the first to be attacked by the gooseberry sawfly maggot, he kept some of these to act as guides in order to know when to spray or dust his plantations, he watched some bushes of this variety day by day, and as soon as he saw the larvae on them, started dusting with hellebore, or spraying the rest of his gooseberry plantations.

\section{The Red Currant.}

The cost of planting and first year's cultivation of red currants was approximately as follows (pre-war):-

(Autumn) Manuring with 20 tons dung

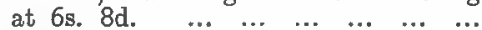
Ploughing, twice cultivating, 4 har$\begin{array}{lllllllll}\text { rowings } & \ldots & \ldots & \ldots & \ldots & \ldots & \ldots & \ldots\end{array}$

Marking out for planting in two directions $5 \mathrm{ft}$. apart on the square (November) 1,743 red currant bushes at $6 \mathrm{~s}$. per 100 £ s. d. out from a main stem above ground. When making the cuttings for bushes to be grown on a leg, all the buds which would be planted below ground are cut out, and only those to be above ground are left. The disadvantage of being on a leg is that if this main stem is broken the bush is spoilt, whilst if the boughs spring direct from the ground, new growth of strong young boughs is readily obtained.

The usual plan for picking gooseberries is to make the pickings as thinnings of the berries, picking the largest and leaving the smaller ones; thus for green gooseberries the bushes may be gone over three

Planting-man digging "holes $\dddot{1}^{\circ}$ foot 'square, and planting, woman carrying bushes, thus costing 1s. 8d. per $100 \quad \ldots \quad \ldots \ldots \ldots$ (April to September) Horse hoeing four $\begin{array}{lllllllll}\text { times at } 3 \mathrm{~s} . & \ldots & \ldots & \ldots & \ldots & \ldots & \ldots & 0 & 12\end{array}$

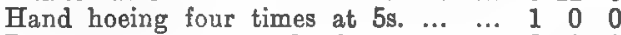
Rent, rates, taxes, and other expenses $210 \quad 0$
6134

230

$\begin{array}{llll}0 & 4 & 0\end{array}$

$\begin{array}{lll}5 & 4 & 7\end{array}$

199

$£ 191511$ 
The annual cost of cultivation of red currants per acre was approximately as follows (pre-war):-

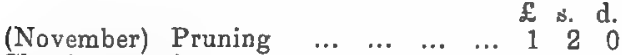
$\begin{array}{llllllllll}\text { Clearing cuttings } & \ldots & \ldots & \ldots & \ldots & \ldots & 0 & 5 & 0\end{array}$ $\begin{array}{llllllllll}\text { Digging with fork } & \ldots & \ldots & \ldots & \ldots & \ldots & 1 & 0 & 0\end{array}$

(April to September) Hand hoeing four times

(August) Picking 2 tons of red currants at $6 \mathrm{~d}$. per $24 \mathrm{lbs}$. ... ... Packing 187 half bushels at 20. Carriage, 16s. per ton ... ... ... ... Sale expenses, $4 \mathrm{~d}$. per half bushel ...

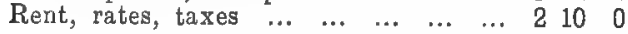

$$
\begin{array}{lllllll}
\text { Cost } & \ldots & \ldots & \ldots & \ldots & £ 15 \quad 16 & 5
\end{array}
$$

Receipt, 2 tons red currants at $\$ 10$

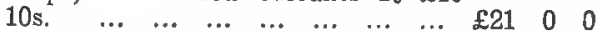

Balance, to cover cost of planting superintendence, etc., and profit ... $2553 \quad 3$ (These costs are increased by about 130 per cent. now.)

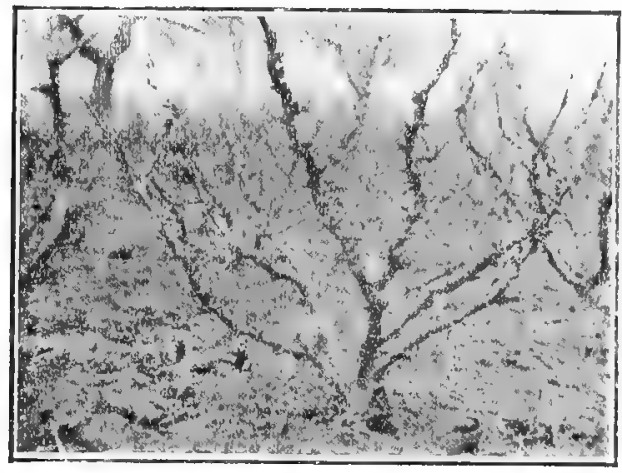

Pruned Red Currant in a Worcestershire Plantation.

About twenty years ago the price of red currants was so low that it did not repay the cost of picking and carriage, and consequently a great many acres were grubbed during the following winter, but since then the price has paid expenses, and afforded a moderate remuneration. The red currant is almost always grown as a bush on a "leg" or main stem, with four or five branches often forking at a short distance into two. As the fruit buds are formed close against the older wood, the pruning consists in spur-pruning all the young shoots, and shortening the leading shoot, leaving about one-third of its length. The tendency is to grow red currants with longer boughs than formerly, and thereby get more fruit. Red currants are usually planted $4 \frac{1}{2} \mathrm{ft}$. to $5 \mathrm{ft}$. apart, or perhaps a little wider on very good soil. As with other bush fruits, the land should be well manured before planting, and other crops may be grown for one or two years between the young currant bushes, if care is taken in cultivating and lifting the crop. In order to encourage quick growth the plantation should be frequently hoed.

In pruning the bushes it is important to cut nearly up to the buds to avoid leaving lifeless snags, which harbour the maggots of the Currant Clearwing Fly.

\section{The Black Currant.}

The black currant is a valuable fruit to grow if one can keep it free of big bug mite. The fruit sells at a higher price than any of the hardy fruits, there being many uses for it. The black currant crop is unfortunately very susceptible to frost. It grows best on land somewhat heavy, rich and moist, and will thrive, though partially shaded, in a mixed plantation.

Unlike red currant bushes, which are frequently grown on a "leg," the branches of black currants should spring direct from the ground. In starting a plantation it is best to plant two-year-old bushes having strong and plentiful shoots and plenty of fibrous roots, also to plant the:n as early as possible in the autumn. in buying young bushes it is of the utmost importance to have them clear of big bud mite (Phytoptus ribis); and a written guarantee should be given that they are clean.

Black currants are now planted about 5 feet apart; before the big bud mite appeared they used to be planted $6 \mathrm{ft}$. apart on good land, but now it is important to get the land quickly covered for fear of an attack. Some growers plant them at $5 \mathrm{ft}$. by $2 \frac{1}{2} \mathrm{ft}$. or $6 \mathrm{ft}$. by $3 \mathrm{ft}$, which allows for horse-hoeing both ways for one year, and sometimes the second year. This close planting allows also for pulling up diseased bushes without making an appreciable gap.

It is said that the best results are obtained in pruning as soon as possible after 
the fruit is off, as is the case with the raspberry and loganberry. The pruning is, however, usually done during winter; the object to aim at in pruning is to keep the plant well supplied with plenty of strong, young wood, as the fruit is largest on young wood; the oldest wood is cut out right from the base of the tree. Some

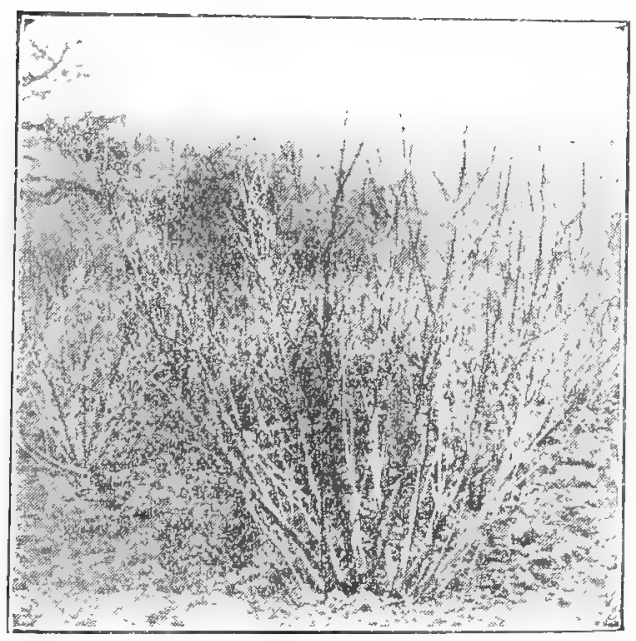

Black Currant Bush at Tenbury.

young shoots should also be cut off right from the bottom to make more shoots come up for the following season; if the young wood is too crowded or weak it should be thinned. Many fruit farmers grow their own gooseberry and currant bushes from cuttings.

Gooseberry, red currant and black currant cuttings usually take well if the following summer is not too dry. For cuttings, free working and rich land is chosen. For black currant cuttings, strong, well-ripened wood 9 to 11 inches long is taken, the green top being removed, and the base end cut close to a bud; all the buds are allowed to remain in order to get a bush with suckers springing from the base below the ground. The cuttings are taken when the sap has gone down in November or December, they are heeled in the ground until February or planted direct in trench, leaving only the point of the cutting above the ground. Some large growers of cuttings use a large plough, following each second furrow by a small plough to make a clean upright cut and throw out the loose bottom soil; the same plough returns up the same furrow after the cuttings have been placed against the land side, and the loose soil is put back again against the cuttings; the soil is then trodden to make the cuttings firm and the big plough again makes two more furrows. The cuttings are planted 6 or 8 inches apart in the line, the rows being about 18 inches apart, which allows the use of a small light cultivator, drawn by a pony, to work between the rows. After being made firm, the tops of the cuttings are cut off with seoateurs, only leaving two buds above ground.

With the object of having plenty of strong young shoots, twelve months after planting, say, at the end of the following Feloruary, all the young shoots which have sprung from the cutting are pruned down to the ground line, only about three buds being left which should point outwards. By this means the number of strong young shoots is increased. Seahrook, Boskoop Giant and Baldwin are favourite varieties. The Baldwin for a time took second place, but is now again getting ahead, as it yields more per acre; Baldwin is, however, very susceptible to the Big Bud mite, but good crops may be obtained before it is attacked. Some crops, such as Brussels sprouts, or other green stuff, or one row of potatoes, may be grown up the middle between the young plants for the first year, but this inter-cropping must not be overdone the second year, or even the first.

Costr per Acre of Planting and First Year's Cultivation of Black Currants-Pre-War.

(Autumn) Manuring with 40 tons dung Ploughing, and subsoiling, four har$\begin{array}{llllllll}\text { rowings... } & \ldots & \ldots & \ldots & \ldots & \ldots & \ldots\end{array}$

Marking out for planting, at $5 \mathrm{ft}$. apart at right angles by marking-machine (November) 1,743 black currant bushes at 9s. 6d. per $100 \quad \ldots \quad \ldots \quad \ldots$ Digging 1,743 holes, $1 \mathrm{ft}$. sq., woman carrying bushes, man digging holes and planting, at 1s. $8 \mathrm{~d}$. per $100 \ldots$ (April to Sept.) Horse-hoeing four times, at 3 s....

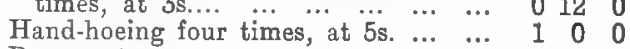

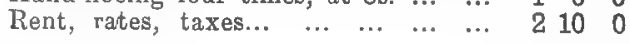

£ s. d.

$\begin{array}{lll}15 & 3 & 0\end{array}$

210

$\begin{array}{lll}0 & 3 & 0\end{array}$

$\begin{array}{lll}8 & 5 & 7\end{array}$

190

0120

33137 
This manuring, although the common practice.in West Kent, may be considered unnecessary unless strawberries are to be grown between the currants. If the currants are grown alone and the land is good, one may wait two or three years befnre manuring, and thus lessen the expense.

\section{SECONd Year's Cultivation-Pre-War.}

(October) Pruning bushes

\& s. d.

(November) Digging with spade, $£ 1$ to

(April to October) Horse-hoeing five

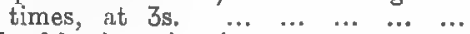

Hand-hoeing six times $\ldots \ldots$....

(July) Picking fruit, 6 half bushels at $1 \mathrm{~s}$.

Packing and splints, " $\frac{1}{2} d$. " per half

$\begin{array}{llllllll}\text { bushel } & \ldots & \ldots & \ldots & \ldots & \ldots & \ldots & \ldots\end{array}$

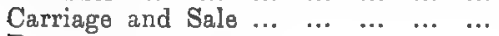

Rent, rates, taxes...

$\begin{array}{lll}0 & 3 & 0\end{array}$

150

0150

1100

$\begin{array}{lll}0 & 6 & 0\end{array}$

$\begin{array}{lll}0 & 0 & 3\end{array}$

$\begin{array}{lll}0 & 2 & 0\end{array}$

2100

£6 113

Cost per Acre of Annual Cultrvation of Black Currants whin Mature-Pre-War.

(October) Pruning

\& s. d.

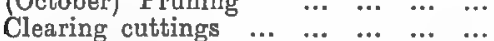

$\begin{array}{lll}0 & 12 & 0\end{array}$

(November) Each alternate year 20

tons dung, with cartage £6 15s.,

wheeling 12s., spreading 3s.—£?

10 s., half of $\ldots \ldots \ldots \ldots \ldots$

or 2 tons shoddy $\ddot{8} 8$ per cent. am. monia) at 50s. per ton ... ... ...

Digging with spade or fork ... ...

(April to Sept.) Hand-hoeing four times, 28s. ; or horse-hoed and hand-

hoed ... $\ldots$... $\quad \ldots$....

(August) Picking one ton black currants at 1s. per 28lbs. ..........

Packing, at 2 s. per 100 half-bushels

Carriage, 16s. per ton... ... ... ...

Toll $\frac{1}{2} d$., sale 3d. per half bushel... ...

Rent, rates, taxes...

3150

100

100

400

$\begin{array}{lll}0 & 1 & 8\end{array}$

0160

$\begin{array}{lll}1 & 3 & 4\end{array}$

$210 \quad 0$

$£ 15 \quad \overline{0} 0$

BALANCE.-For unforeseen expenses, superintendence, interest on cost of

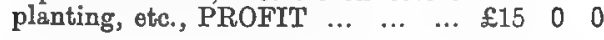

RECEIPT.-One ton black currants at $£ 30$ per ton ...

With reference to manuring, artificial manure may take the place of dung after a good start has been made. Probably the best result of all is obtainable by giv. ing dung and artificial manures in alternate years, or light dressings combined.

During winter these plantations are pruned, manured, and dug by spade if the land is not too stoney, which is very often the case: if this is so it is dug by a fork with three or four broad tines. During summer the plantation is hand-hoed three or four times-the first hoeing used to cost about $10 \mathrm{~s}$, the others $6 \mathrm{~s}$. or 7s. per acre for hoeing all the ground. If planted in rows both ways, a pony or horse cultivator will take the place to a large extent of the hand hoe and do it much more efficiently. If the land is kept clean by horse and hand hoe, it is probably possible on some soils to dispense with digging.

The above estimates of cost were originally made with the kind help of the late Mr. Thomas Wood, of Crockenhill, Kent, who was at that time probably the largest fruitgrower in England; his brother, Mr. John Wood, at present has some 1,200 acres under fruit. Mr. Sydney Lee, of Crockenhill, has most kindly revised this article in several points. He told me my estimate of 2 tons was now far too rosy (owing to the decrease in crop due to the mite), and that half a ton would be nearer the mark of late years, sometimes only quarter of a ton, and that it needs a good piece to get $1 \frac{1}{2}$ tons. The price is very speculative, and for black currants for contracts, worked out at $£ 32$ per ton, and on open market $£ 40$; he has known them make 256 , but only in a year when "Jack Frost" had cut them worse than usual. Before the spread of the "mite," a usual price was $£ 17$ per ton, say 20 years ago.

The prices in 1919 for gooseberries sold by contract was up to about $£ 40$ per ton, for black currants up to $£ 100$ per ton, and for red currants up to $£ 35$ per ton.

Black currants yield from about half a ton to 2 tons per acre, the bushes give remunerative returns from about their third year, are at their prime from their fifth to their tenth year, and live 15 to 20 years if not attacked by the mite.

The greater part of this article appeared in "The Journal of the Board of A griculture, for November, 1909, under the title "Small Fruit Growing in Kent," by C. H. Hooper, and is reprinted here with the kind permission of the Controller of His Majesty's Stationery Office. A few alterations and additions have been made. 
Additional Nutes on Yields of Small FRUITs.

Red Currants. -1 to 4 tons, average yield $30 \mathrm{cwts}$. Prices are very variable; within the last twenty-five years the price has been $£ 6$ per ton, and one year the price was only $£ 4$ per ton, when the fruit was not picked; the prices recently, however, have been fairly good. Pre-war prices ranged from, say, £14 to $£ 26$ per ton. Aphis attack (honey dew) is a serious pest on some varieties, especially old Dutch; it spoils the fruit for market purposes. A plantation of mature good bushes will sometimes cost nearly $£ 4$ per acre to prune. Red currants should be in rows at right angles, to allow horse cultivation for the first four years.

Raspberries do not crop as heavily as strawberries; they yield nothing the first year, and not much the second year. Average crop after third year, 1 to $1 \frac{1}{4}$ tons per acre (prohably nearer the 1 ton in Kent). The price varies considerably, as the crop may be only a few cwts. in an abnormally dry season, or if frost injures the blossom. The price has in recent years ranged from $£ 10$ per ton to as high as $£ 56$. An average price before the war was $£ 20$ per ton.

Strawberries, excluding first year, yield 3 to 5 tons per acre, if good, for the second and third year, and in the fourth year half this amount. Price has varied from $£ 6$ per ton for " Fillbaskets" in wet, cold summers, to $£ 56$ for best quality fruit in a season of high prices. Average prewar price, £14 to £16 per ton. Forty tons have been delivered in one day at a jam factory by two brothers from 600 or 800 acres of strawberries. The varieties of strawberry now being grown for market in Kent are:-Royal Sovereign, Sir Joseph Paxton, Stirling Castle, Bedford Champion (the largest fruit and heaviest cropper, but soft), and Kentish Favourite; also many new sorts are being tried. $£ 90$ was paid for 3,000 Bedford Champion runners. Forty years ago, Elton Pine and Count de Paris were the varieties chiefly grown, now Paxton and Stirling Castle are nearly worn out in most districts. Mildew is occasionally very troublesome, also the "Elephant Bug" is sometimes very destructive in piercing the stem just behind the bloom bud. The information contained in these notes was kindly given me by Mr. Edwin Vinson, of High Croft Hall, Crockenhill, Kent, and by Mr. S. Lee.

In the planting season 1919-20 the price of good gooseberry plants, two years old, was $£ 4$ per 100 , of one year old, 50 s. per 100; black currant plants $£ 2$ per 100 , and red currant plants 30s. per 100 .

Reversion or Nettle-head in Black CURRANTS.

Bushes showing this ailment should be grubbed, as also those bushes which have "big bud" to any extent. 


\section{CHAPTER XII. \\ THE COMMERCIAL CULTIVATION OF THE LOGANBTRRY.}

By Geofrrey Fimider Hooper, of Pershore, Worcestershire.

The loganberry, a cross between the raspberry and the blackberry, was raised originally in California, and so named by the raiser, Judge Logan. berries measure $1 \frac{1}{4}$ inches in length. In flavour it is somewhat more acid than the raspberry, but it resembles the blackberry in that the core or plug remains

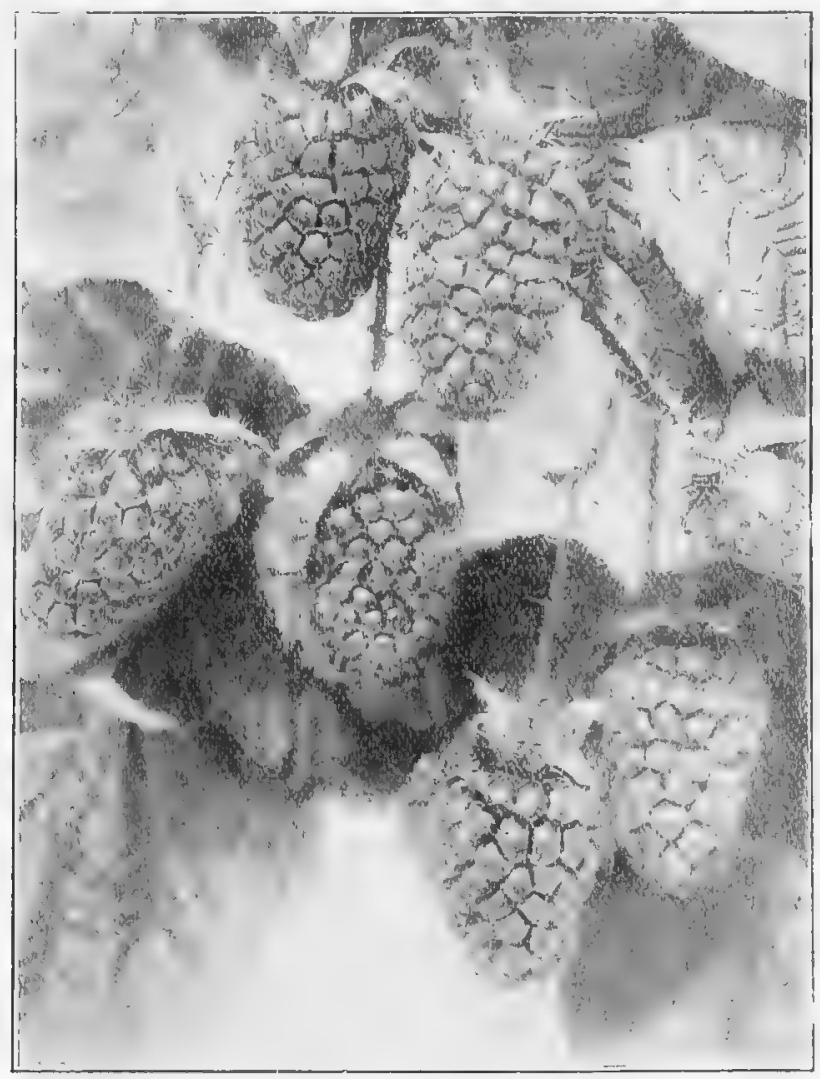

LOGANBERRIES.

It is a fruit of much the same colour and character as the raspberry, but it is far larger and much more prolific. Many in the fruit when the stalk is removed. The fruit is admirable stewed. Its chief use, however, has been for bottling pur- 
poses, one firm of preservers alone having in the season purchased some ten tons for this purpose only. Other manufacturers are planting large acreages to supply their own future requirements. The fruit is also largely used for jam, the preserve being very popular; it has shown a tendency, however, to become candied after keeping some time, but this can probably be rectified with experience in the boiling and preparation of the preserve.

As a dessert fruit the logan is delicious, being sharper and more refreshing in flavour than the raspberry, but for this purpose the berries must be allowed to become perfectly ripe on the canes. In its half-ripe and firm state it is rather acid, and for this reason, if the fruit is cultivated for dessert purposes, a market fairly close at hand is desirable. It has become especially popular in its fresh state among mining populations, where a fruit with some acidity is much appr?ciated.

The loganberry has only been commercially cultivated on any large scale in this country during the past fifteen years. Several growers now have areas of five acres in full bearing, and as these yield up to four tons of fruit per acre, an appreciable quantity is now available, and the loganberry may be said to be fairly established in this country as one of the hardy British fruits. In some instances hop growers have utilised their hop yards for the cultivation of logans, the poles and wires being adaptable for the purpose.

The period of fruiting of the canes is a lengthy one; the writer from his own plantations picked fruit in prime condition from the middle of July to the end of August. Pickings should be made two or three times a week, according to the weather.

Cultivation.- The canes (which should be strong and well rooted, and for preference only one year old) should be obtained from some source to be relleu upon as to purity and genuineness of stock. They must be planted, if possible, in November. (In the case of rooted "tips," the planting may be done in April). The rows should not be more than 80 to 100 yards in length, 8 feet apart, and plants 8 feet from plant to plant; thus 650 to 700 canes or rooted tips are required per acre.

"Tips," or rootlets, are obtained by laying the tips of the canes of established stock plants in the soil and allowing them to root. When rooted they are severed from the parent, and transplanted either into permanent plantations or into a bed, where they develop into canes, or "yearlings," as they are termed in the trade. No system of wiring is necessary the first year, though some experienced growers prefer to put up their wiring before planting; this, however, is not absolutely essential, as the old and young canes may both conveniently be tied to a stout stake. Where canes have been planted in the autumn, some fruit may be expected the summer following; many market growers, however, adopt the same method as with raspberries, and cut the original canes back within a few inches of the ground shortly after planting in order to concentrate all the strength in the new growth.

The first year after planting, a crop such as potatoes, peas, beans, or tomatoes may be planted between the rows; the spaces between the logans in the rows may also be utilised if desired. After the first year a thorough system of wiring is absolutely essential to success. The posts at each end of the row should be stout (railway sleepers do very well); they must be well tied down to blocks under the soil and well strutted. All timber used should be well creosoted or tarred. All posts should be six feet out of the ground, with two or three feet underground, and there should be six wires a foot apart, the first one foot off the ground, the sixth at the top of the post; holes should be bored through the posts when in position, and the wires should run free so that they may be strained with some system of strainers from one end. The posts should be 15 to 20 feet apart.

The whole work must be thoroughly and strongly done, the weight of fruit and foliage being very heavy when in full bearing, and the wind resistance very great.

The old canes should be cut out and burned immediately after the fruit is gathered, and the new canes tied up to ripen. It is advisable, if possible, to 
have all the canes running in one direction, preferably not facing the prevailing wind. The rows should be ploughed or dug each autumn, and hoed or horse scuffled to keep down the weeds in spring and summer. As with raspberries, plenty of manure, both stable and artificial, is desirable in order to obtain the best results.

The greatest difficulty in logan culture arises from the mass of young wood with soft twine, one cane along each wire. The fruit should be picked before it is quite ripe, and despatched in chip baskets containing not more than 6lb. each. Oiled paper should be put at the bottom of the basket.

The loganberry plant lasts a long time with proper cultivation, and experience appears to show that it is not very susceptible to spring frosts. It has, however, two foes which have recently made their

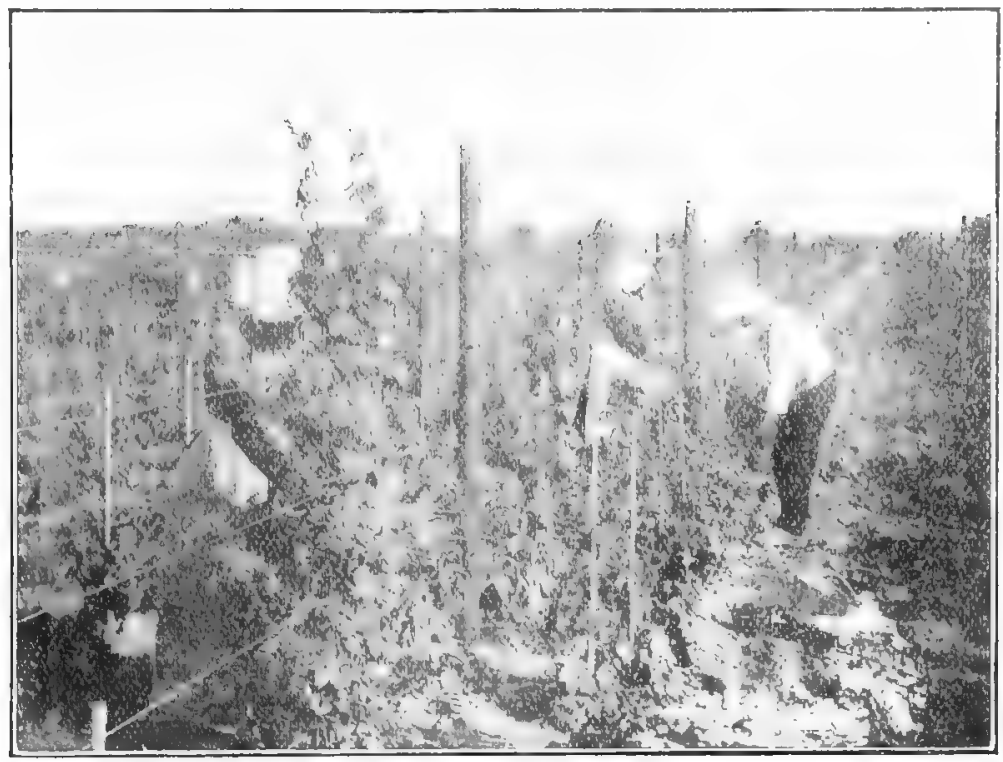

Training Logan Canes.

thrown up in the spring. A number of methods have been tried; possibly the bes's is to drive stakes into the ground near each plant, one at each side of the wire fence, and tie the young wood up to these. It is desirable only to leave seven or eight shoots from the base; a larger number than this is unmanageable and not necessary. The young wood should be tied to the wires in the early autumn appearance, and in some cases caused considerable damage and anxiety to growers, the Raspberry Beetle (Byturus tomentosus), and also a blotch, presumably a fungoid disease, which attacks the cane, for neither of which has an entirely satisfactory remedy been forthcoming. In conclusion, it should be said that the loganberry is a gross feeder, and requires plenty of nourishment and attention. 


\section{CHAPTER XIII.}

\section{THE APPLE.}

The Cholce of VARIETIEs.

The apple was a favourite fruit of the Romans, and is the most useful of British fruits. It thrives in most parts of the kingdom, though Kent, Worcestershire, Herefordshire and the Wisbech district are the chief locations in which it is extensively planted for market. Each part of the country has its special varieties, though
James Grieve, and Mr. Gladstone; and for cooking, Bramley's Seedling, Newton Wonder, Lord Derby, Grenadier, Lane's Prince Albert, Bismarck (for which some people suggest the name of Lord Kitchener, it was raised in Australia), and Stirling Castle. I think most Kentish growers would agree that this is a very good selection. Although Miller's Seedling is not

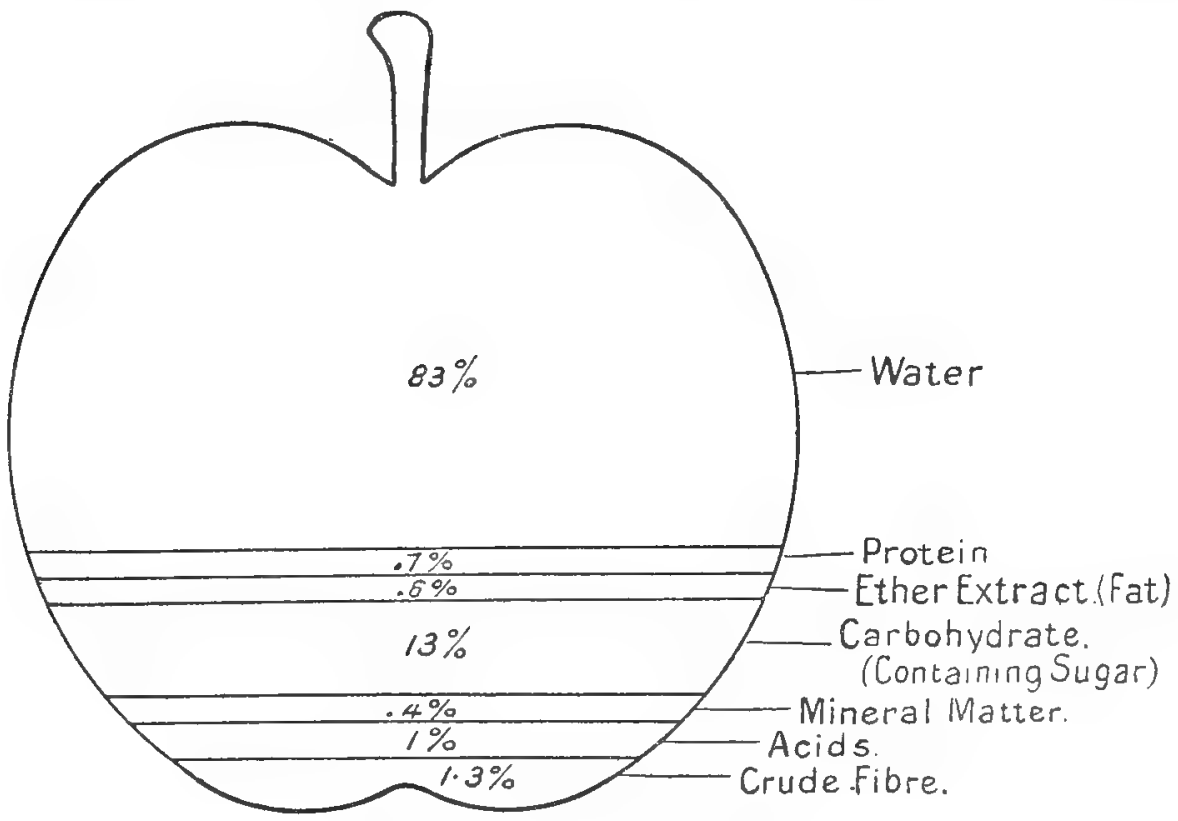

Constituent Properties of an Apple.

some varieties appear to be well suited to all districts; the Royal Horticultural Society has recorded much information on this subject. Mr. George Mount, of Canterbury, gave as his experience of the best apples for Kent the following: For dessert, Worcester Pearmain, Allington Pippin, Beauty of Bath, Miller's Seedling, well known, it is a very nice eating apple and crops heavily; it is of better quality than Worcester Pearmain, though not so showy, and ripens somewhat earlier. In addition to these twelve market varieties already mentioned, the following varieties are found in the plantations of some of the best apple growers round Maidstone and 
at Crockenhill:-Golden Spire, Graham's Royal Jubilee, Duchess Favourite, Scarlet Nonpareil, Grenadier (the latter makes a good plantation with Bramley, Grenadier being a smaller grower, whilst Bramley makes a large tree, though somewhat slower in coming into bearing), Baumann's Red Winter Reinette (though not good quality is a good keeper), Smith's Improved Yellow Ingestre and Early Victoria; of newer varieties Ben's Red, Rival, Norfolk Beauty, Foster's Seedling, and King Edward VIr. are being tried.

In Worcestershire, the varieties chiefly planted include Bramley, Lord Grosvenor, Newton Wonder, Stirling Castle, Lane's Prince Albert, Ecklinville (where it suits), and Early Victoria, and for dessert only Worcester Pearmain is considered to pay, though Allington and James Grieve are being tried. Saltmarsh's The Queen is found to be a good cooking sort. As an example of a variety that thrives well in one district and badly in another "Warner's King " may be mentioned; it is liable to canker in Kent, but luxuriates at Toddington, where it is one of the best varieties, does not canker, and crops well even when planted in block.

Cox's Orange Pippin is the Queen of English apples, but it has proved so disappointing in many plantations that in a district where it is not known to prosper, it is advisable only to plant in small quantity on trial, it is a variety that particularly wants cross-pollination. Worcester Pearmain has in many cases been proved to be a good pollenizer for it. It is a variety more fanciful than most varieties as to cross-pollination.

Blenheim Orange is perhaps the next best apple, especially in Worcestershire, but takes long to bear and is now but little planted; near Malvern, are trees on pasture that took twenty years to come into bearing, but then yielded about 6 pots of fruit each.

The old King of Pippins, the Reine de Reinettes of the Flench, is a good dessert apple where the trees grow healthily. For anyone who wishes to know something of the history of the different kinds of fruit, I would recommend the last editions of Bunyard's Fruit Catalogue (price $6 \mathrm{~d}$.), in which Mr. Edward Bunyard gives the origin of a great many of the fruits. The facts are quite interesting, and add poetry to the prose of fruit growing.

For standard apple trees planted in pasture fields, the distance apart recommended for planting is $30 \mathrm{ft}$. to $40 \mathrm{ft}$., according to variety and soil, and for half standrords in cultivated fruit plantations $18 \mathrm{ft}$. to $30 \mathrm{ft}$. apart, according to variety, etc. Wide holes should be dug for the trees and the soil stirred deeply and made fine to encourage quick rooting.

Bush Apples.

During the last 20 or 30 years the planting of "bush" apples has gradually become popular in preference to standard and half-standard trees. To the late Mr. Thomas Rivers, of Sawbridgeworth, is chiefly due the introduction of this form of tree. The various dwarfing stocks on which apples are budded or grafted is being specially studied at Malling and Long Ashton fruit experiment stations.

Reliable, painstaking nurserymen, from experience, have found which stock, whether broad leaved English Paradise, Nonsuch, or free stock are best suited to a certain variety of apple, and supply it; most of the stocks, up to the war, came from France, chiefly from Orleans. Many plantations, however, have suffered from trees being worked on unsuitable stock. To avoid this the best information on the subject should be obtained, known and classified in order that the trade should not be dependent merely on the good judgment of experienced foremen.

The advantage of "bush" apple trees over tall standards and half-standards is their "get-at-ableness" for pruning, spraying, and gathering, and their earlier fruiting. They begin to be profitable at four years old, whereas a standard apple tree does not bear very much up to ten years old, after that its production augments rapidly to 35 or 40 years, from then up to 50 or 60 it is at its maximum state of fertility; after that it declines, and at the age of 80 is unprofitable to keep longer.

I have somewhere seen the following estimate of the average apple crop of Great Britain : 70 million bushels of apples from $27,200,000$ trees, allowing an average of two bushels per tree, 160 trees per acre 
yielding six tons per acre. This may possibly be the case including cider apples. I think it is probably too high for the average of eating apples.

It needs to be a good and well managed plantation of "bush" apples to average two bushels of fruit per tree.

The distance apart to plant apple trees is a very important point to determine, this will depend upon soil, variety and locality. I commenced by planting an acre of bush apples at 9ft. apart, but realizing this to be too close, made other plantations, one at $12 \mathrm{ft}$. apart on the triangle, another at 10ft. apart on the square. Mr. Mount plants strong growers, such as Bramley's Seedling and Newton Wonder, 24ft. apart, with close growers, such as Worcester Pearmain, between, thus making a 12 foot plant, if eventually the Bramleys want all the room, the other trees are grubbed up.

In planting it is advisable for the sake of better pollination and consequent fruit setting to alternate varieties in the rows, preferably having two rows of one variety then two rows of another variety. It is desirable to keep bees to ensure the best cross-pollination. Some varieties appear somewhat tolerant of being planted in block, Bramley's Seedling appears to be less affected than most varieties; but Lane's Prince Albert is very intolerant, and fruits extremely badly if planted in block alone.

Having been asked to reply to a gentleman in Canada on questions as to English fruit-growing, the first question was:What is the cost of planting an acre of orchard bush apple trees? I consulted with the late $\mathrm{Mr}$. H. T. Getting, of Ross, Herefordshire, a skilful grower, with large plantations, who also kept accounts, and the following was our joint estimate.

The Cost of Planting an Acre of Bush APPLE TREes (without other fruit) previous to the war:- $\&$ s. d. Cultivating and cleaning land, say $\quad \begin{array}{llll}1 & 10 & 0\end{array}$ Setting out plantation for trees

$12 \mathrm{ft}$. apart .......................... 010

303 bush apple trees (2 years

old), at 1s. each .................. $15 \quad 3 \quad 0$

Digging holes and planting, at

10s. 6d. per 100
The expense of cultivating previous to planting may be more, dependent on the condition of the land and whether fairly clean. To have the land clean before planting is of the utmost importance, especially to get it clean of couch grass or twitch; the above would include ploughing, followed by steam cultivating or subsoiling, harrowing, etc. I had put down \&5 for manuring, but $\mathrm{Mr}$. Getting considered no manuring need be done when planting.

\section{Y IELD}

Another question was:-What an acre of bush apples might be expected to yield in fruit, and the cash return?

Mr. Getting considered these trees, when mature, should give an average yield of 40 to $841 \mathrm{lbs}$ of fruit per tree, but that the yield was practically nothing for the first four years, and very little for the fifth.

He found $401 \mathrm{bs}$. an average weight of a bushel of apples, and put the average gross price at $8 \mathrm{~s}$. to $10 \mathrm{~s}$. per cwt. for cookers, and the average of first, second, and third dessert apples at $12 \mathrm{~s}$. to $14 \mathrm{~s}$. per cwt., some varieties fetched more. The cost of picking and packing apples he found to be $10 \mathrm{~s}$. to $15 \mathrm{~s}$, per ton.

Records of yields of fruit per acre should be kept yearly. It is surprising how much some trees will yield; in an old orchard at Swanley which I farmed, a large tree of Dredge's Fame when probably 60 to 80 years old, one year yielded about a ton of apples, but they only fetched about $1 \mathrm{~s}$. a bushel that year. It is not a popular variety.

The future costs and prices are a great uncertainty; that the cost of production will be more we may take for granted, and for the producers' sake we hope prices will keep up, and for the consumer that the ratio between wholesale price received by the grower and that paid by the retailer may somehow become nearer, say a difference of 50 per cent.

\section{MANURING.}

The question of manuring apple trees is a debatable subject, especially after the Woburn fruit farm experiments. Experiments in other places, as in the United States of America, should also be studied.

I think it is correct to say, even if there 
is no manuring at planting, that if a dry season follows the planting it is advisable to mulch around the young trees with stable manure to help retain moisture; also that apple trees carrying a heavy crop of fruit are undoubtedly benefited by a mulch of stable manure on the surface of the ground over their roots, for small trees, say half a bushel of wellrotted stable manure to a tree. The Americans consider a dressing of nitrate of soda good for old trees as a revivifier.

Very useful experiments were carried on till the war at Hadlow, near Tonbridge, to see the effect of various manures on regetables and fruits.

The general conclusion with apples was in favour of a light dressing of dung, supplemented by artificial manures supplying nitrogen, phosphate and potash. Where dung is given the importance of the additional potash is not so great, but on plots manured with artificials only, where potash was omitted, the difference was very marked, as the growth of these trees was less, and the leaves showed an appearance of being scorched round the edges, and the fruit was smaller in size. The addition of potash is by some people thought to improve the colour of the apple.

"Silver Leaf" is a serious disease among apples. I once saw an acre or more of re-grafted apples thus affected, at Crockenhill, in Kent. As regards the treartment of "Silver Leaf" in apples, the late Mr. Arthur Miskin showed me six trees that had suffered with "Silver Leaf" ; during the following winter he had topdressed each of these trees with about 6lbs. of sulphate of iron. The following year five of the trees were healthy with vigorous dark green foliage, the sixth was so far uncontrolled, and was to be topdressed again.

On some farms water is laid on by pipes to orchards, either under the ground or temporarily by 2 inch pipes; in one case it was thus conveyed for half a mile from the buildings. Here in an exceptionally dry summer I saw men with 60 feet hose pipes, terminated by a rose, watering the ground under the trees, which thereby swelled the fruit.

Pipes are used for spraying hop and fruit plantations.

On many farmis in Kent and Worcester- shire the water is obtained from streams, reservoirs, wells, etc.; the spray is made and pumped through the pipes by an oil engine.

\section{YIELD Per ACRE.}

In 1908 under the Census of Production Act, the Board of Agriculture collected statistics, and estimated the average yield per acre in Britain as 26 cwts. for apples; $19 \mathrm{cwts}$. for pears; $15 \mathrm{cwts}$. for cherries; 46 cwts. for plums; $29 \mathrm{cwts}$. for strawberries; 22 cwts. for raspberries; and 21 cwts. for gooseberies. These appear small in case of the apple.

Sir Charles Whitehead, in an interesting article on "British Orchards," in the Royal Agricultural Society's Journal, said :-"As many as 500 bushels of apples per acre have been grown in plantations where the trees were in their prime. Taking an average of seven years of the average apple-growing land in the country, the crop per acre per annum would be about 130 bushels."

There is a tendency in many varieties of apples (Blenheim, Nowton, Bramley) to crop well one year and rest the following year. In 1919, 200 fifteen year old Bramleys yielded 2,500 bushels on Westerfield Farm, Linton, near Maidstone.

\section{APPle Yields IN OTHER LANDS.}

It is of interest to hear what other countries can do in fruit growing in the "Field," of July 19th, 1919. Arthur Garnett, of Tasmania, wrote: "I should like some information as to high apple yields in England. Here is an authentic example of what must be about the best Tasmania can do. This season (1918-19), 11,000 bushels have been picked from a 10-acre orchard in the Huon district, parts of it being estimated to yield 2,000 bushels per acre. My purpose, however, is not to induce people with an itch to get rich quick to rush hither. I have quoted a yield of over 1,000 bushels per acre, but crops range from that down to practically nil; 200 bushels per acre is reckoned a good crop, and official returns of all bearing apple orchards give an average yield of 73. bushels per acre for the season 1916-17. I doubt such a yield being profitable."

Turning to a little pamphlet "Fruit growing in New Zealand," issued by the Education Department of the New Zea- 
land Expeditionary Force, the following is given as the approximate cost per acre of producing an apple plantation in New Zealand:-

Land suitable for planting per acre $£ 10 \quad 0 \quad 0$

Apple trees 20ft. x 20ft. (approximately 100 per acre) ...

Preparation of land (subsoiling, planting, etc.) ............

Cultivation, pruning, spraying, etc., \&7 per acre per annum for first three years

Ditto next four years, 29 ..... $36 \quad 0 \quad 0$

Total expenditure at end of seven years per acre ...... $₫ 77 \quad 0 \quad 0$

To this must be added rates, taxes, interest, etc.

Orchards at this age are changing hands in New Zealand at prices as high as $£ 200$ per acre.

Returns from the 7th to the 10th year will vary, but should be considerably greater than expenditure.

At ten years planted out a properly cared for orchard should yield 5 bushels per tree, which at 7s. 6d. per bushel gives a gross return of $£ 187$ 10s. per acre. Under pre-war conditions in New Zealand the apple could be produced, after paying all expenses, at 3s. 6d. per bushel case. Orchards in New Zealand are known to produce as much as $£ 300$ per acre gross in one season.

In Nova Scotia about $£ 200$ per acre used to be the price per acre for an apple orchard in full bearing.

In a bulletin of the U.S.A. Department of Agriculture, published in 1917, the average yield per acre of apples in Western Colorado is put at 284 bushel boxes per acre, the average age of the trees being 17 years of age, planted 74 trees per acre.

\section{SPRAYING.}

For the winter cleaning of the bark from lichen, moss and scale insect, etc., caustic potash or soda are wonderful cleansers, giving the bark, if regularly used for several winters, the appearance as if the trees had been varnished. Lime washing the trunks of trees is an excellent and in- expensive practice. Spraying trees all over with as thick lime wash as a pump will carry is very beneficial in cleaning the trees, checking certain insects including apple sucker (Psylla mali), a very serious pest, also probably aphides. This is found to be best done in spring, as near as possible to the opening of the leaves and blossoms. The standard fungicides are Bordeaux mixture (copper sulphate and quick-lime), and lime sulphur which within the last ten years have been replacing to some extent Bordeaux mixture as being less liable to burn the foliage of certain apples. Where apples are liable to fungoid disease either of these sprays are used, the Canadian and U.S.A. practice which we are following in England, is to spray just before the blossoms open, just after petals have fallen, and a third time

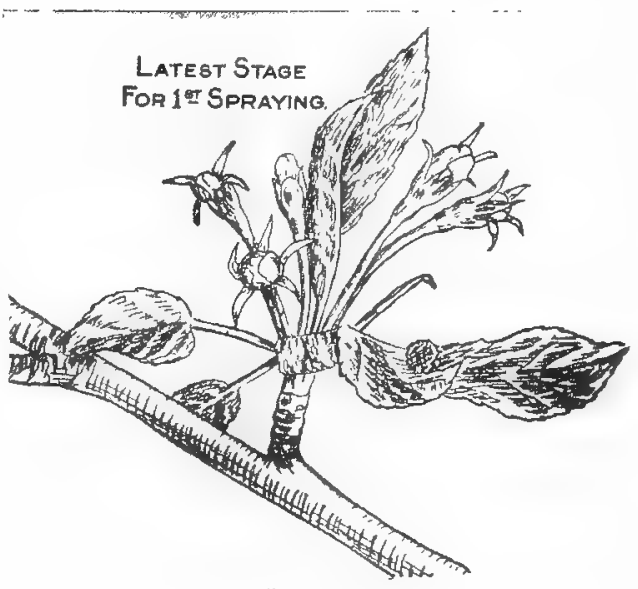

Figure 7.

First Spraying before blossoms open, to destroy spores of apple scab and other fungi and caterpillars of winter and other moths.

about a fortnight later; the second and third spray may advantageously have arsenate of lead added to kill codlin and winter moth caterpillars. Arsenate of lead has replaced Paris Green as less liable to scorch foliage, but costs more. In case of aphis attack, nicotine is found even bebter than quassia and soft soap, but it needs to be applied before the leaves be- 
come curled. In the case of an orchard badly affected with apple scab or brown spray fluid per acre, with motor pump using 6 nozzles, 13 men sprayed 8 acres a

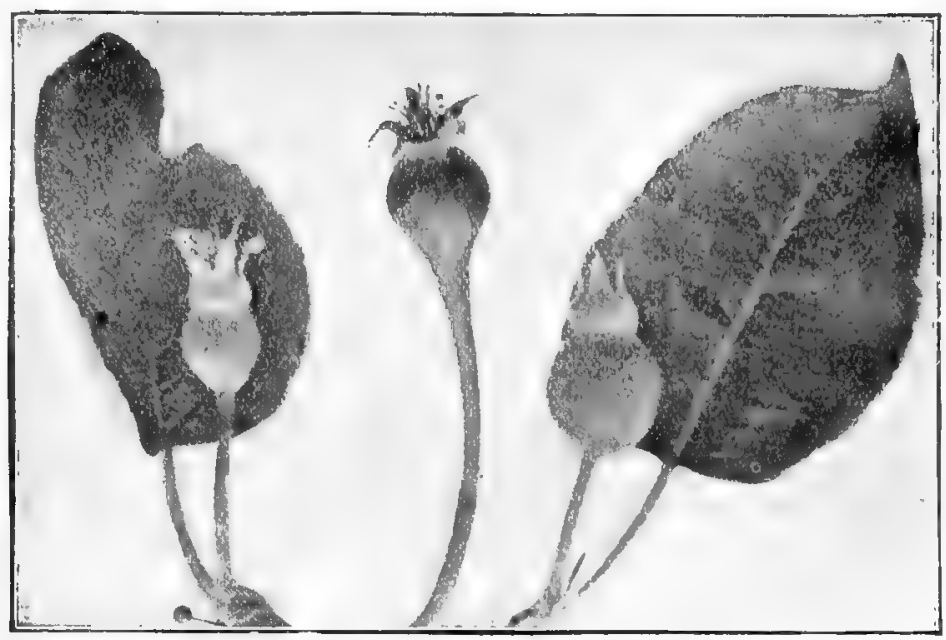

SECOND Spraying, petals fallen, but calyx still open; the object being to kill the young caterpillars hatching out from eggs laid in the open flowers.

rot, the best treatment may be to spray with lime-sulphur in winter, and with Bordeaux mixture in spring.

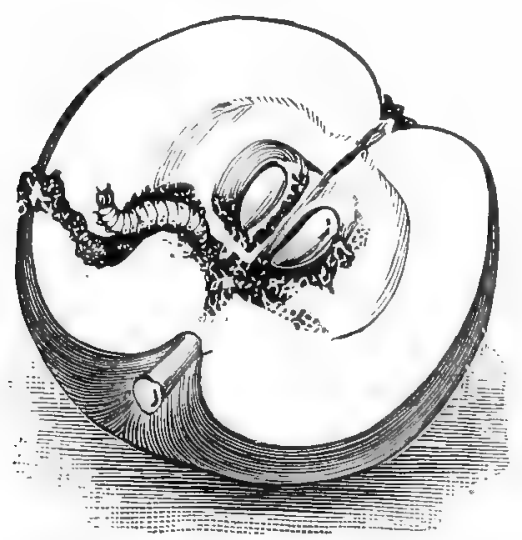

Codlin Moth Caterpitlar in an Apple.

To prevent damage by this insect spray with a poisonous insecticide directly the petals have fallen.

To spray well-grown apple trees 20 years old, it took about 500 gallons of day on Colonel C. Murdoch's farm near Maidstone.

The apple sawfly maggot has not yet been conquered, and apparently the only check at present is to pick up the young fallen apples from the ground, and to gather from the trees the fruits that show themselves worm-eaten and destroy them all.

Good cultivation in the way of frequent hoeing, sufficient sunlight and sufficient manuring is a great help towards resisting fungoid and insect attack, by keeping the trees healthy. I have seen a magnificent crop of apples on land having two or more inches of tilth, obtained by hoeing some six times during the season with the maxim that a good tilth resists drought.

\section{Gathering.}

In gathering apples from a ladder, a picking basket with handle is generally used, which can be hooked on to a rung of the ladder. Some gatherers use a sack slung under the left arm, with a slit in the sack where the fruit is put in. Gathering sacks are made with hole at bottom of sack to let fruit slide out, but the fruit is 
retained in the sack by a large hook and eye arrangement. Gathering barkets are lined with sacking.

In gathering fruit from bush or cordon apples, the fruit can be placed direct into half-bushel or bushel baskets in order to prevent bruising; careful growers place wood wool at the bottom of the basket and a strip of corrugated brown paper round the inside.

Apples are sorted into three or more grades, such as "fancy," firsts, seconds, the diseased or pecked fruit together with the very, very small ones being taken out, the latter can be used for feeding animals.

Fallen fruit should be picked up as soon as convenient, washed if necessary, sorted and carefully packed, and sent to market as soon as possible, as "Falls." The bulk of the apples, picked according to season of the variety, go to market within a day or two of picking. As a rule apples should not be sent to market before their season, unless the price is good, and keeping apples should be stored till mature, to avoid putting these on the market at the season of early kinds.

\section{STORING.}

Varieties that should be stored will keep well in half-bushel and bushel boxes or baskets, through which the air can circulate, all diseased and pecked fruits being taken out. Apples keep best where dark or nearly so, and cool, the cellar or shed should be frost proof, with a natural earth floor which prevents the air getting too dry; concrete floors are good, though not quite as good as earth, but are rat proof. A very good leaflet on Fruit Storage has been issued by the Board of Agriculture and can be obtained free. The apples need sorting over from time to time (say, once a month), to take out any that are decaying.

\section{Packing.}

When apples are packed in bushel or half-bushel baskets for market, one or two large sheets of blue or pink paper are laid on the inside of the basket, which will be held in place by the fruit. After filling the basket the paper is folded over the fruit; this is covered over with straw, or lucerne, with two splints (usually pieces of hazel or cob-nut wood) placed crosswise to retain the fruit. Some of the most enterprising growers pack their choicest apples in bushel boxes. Boxing is chiefly suited to the best and prettiest dessert apples, unless apples are wanted to travel long distances. The boxes are packed with the apples that will form the top layer when opened placed in first. The sorting tables are lined with sacking to avoid bruising the apples. Many large growers use machines which grade and sort the fruit as to size. To the late $\mathrm{Mr}$. Arthur Miskin of Ladd's Court, Chart Sutton, near Maidstone, is due the credit of being pioneer in the use of bushel boxes for apples; he was also probably the first in England to use lime-sulphur spray in his orchards. A bushel box will hold 45 of the finest Queen or Lord Derby apples, 135 good Beauty of Bath, or 180 good Duchess Favourite. The weight of apples in a bushel box varies with the variety and size of the fruit, thus Gladstone and Beauty of Bath each weighed $361 \mathrm{lbs}$., whilst Bramley's Seedling weighed 42lbs. Previous to the war, some of the wood for the boxes came from Sweden, in slats, branded with name and trade mark of the fruit grower, the material costing $6 \mathrm{~d}$. per box. It took about four minutes for a quick man to nail the pieces of a box together, a framework being used to save time. The weight of the box was about 8lbs. Nails dipped in cement water are used, bought ready prepared. A mechanical press to hold the box and press it for nailing is necessary for neat and quick work. The methods of apple packing will be dealt with in another article. Some Kentish growers pack their cooking apples in barrels, and find it a good method.

As to the length of time apple trees worked on Paradise roots will live, it was once said 20 to 60 years, but it seems probable that they will live as long as on the crab or "free" stocks, as there are large healthy standard trees on Paradise stock nearly 50 years old at Messrs. Bunyard's nurseries near Maidstone.

As to crops of individual trees, I have seen in Kent the following approximate crops:-On a Bismarck tree fifteen years old, half standard on crab stock, 10 bushels of apples; on a Cox's Orange Pippin, seven years planted, 1 bushel of fruit; on Bramley's Seedling, well established, mature trees, 6 or 7 bushels per tree, but 
these are exceptionally goor yields, and will not do for a per acre basis.

The experience in Worcestershire is, that early apples pay best, as they crop more regularly than late apples and do not meet the competition of Colonial apples, the loss of stored apples through waste, sweating, and evaporation is estimated at 20 per cent. in the way they are generally stored, placed on the floors of barns or lofts to a depth of one or more feet, with occasional sorting in a rather rough and ready way.

The Blenheim Orange, for which Worcestershire is famous, is not planted now, as it takes 15 or 20 years to come into bearing. This variety used to be planted 10 or 15 yards apart in arable or pasture land; a grood tree will yield 10 pots (560lbs.), well-developed trees usually yield about 5 or 6 pots, but the yield depends so much on the size of the tree and the fruit that the yield may be anything between 2 and 10 pots.

\section{Greise Banding.}

Grease banding to catch the "wingless" female of the Winter and March moth was first thought out and practised by a clergyman in Worcestershire some 50 years ago; by using coal tar and penetrating greases on young trees many trees throughout the country have from time to time been killed; but by the use of more suitable grease and grease-proof paper the good practice of grease banding standard and half-standard fruit trees is extending, especially since a grease has been introduced which keeps "tackey" for a long time without having to put on more. Using grease-proof paper and about 10lbs. of "Tanglefoot" per acre, the cost of grease banding has been esti- mated to cost about $£ 1$ per acre in an average apple plantation.

C'IDER.

Cider, perhaps the most wholesome and least to be condemned of all alcoholic beverages, is a product of the apple orchards, chiefly of Devon, Somerset, Hereford, and Worcester. The apples are grown over grass, and the trees look very picturesque in spring and autumn. A fair crop is 600 bushels of cider apples per acre, equals $150 \mathrm{cwts} .548$ trees per icre, equals 3 cwts. per tree, though fullgrown trees at their prime produce more.

It takes a little more than 30 bushels of apples to produce 100 gallons (hogshead) of pure cider. Partly diluted cider such as was given to the farm men, sold at 75s. per hogshead (pre war); nice table drinking cider at $£ 6$ per hogshead; the very best bottled cider fetched up to $£ 20$ -per hogshead, but this price is somewhat exceptional.

Alproximlte Order of filowerisg of Apples COMMONLY Grown for ilarket.

Eurly.-Golden Spire, Stirling ('astle, Bismarck, Baumann's Red Winter Reinette, Warner's King, Ben's Red and Norfolk Beauty.

Merlinm.-Duchess Favourite, searlet Nonpareil, Cox's Orange Pippin, Miller's Seedling, Early Victoria, Lord Grosvenor, Beauty of Bath, Worcester Pelarmain, Allington Pippin, James Grieve, Early Julian and Rival.

Late.-The Queen, Lord Derby, King of Pippins, Blenheim Orange, Lane's Prince Albert, Grenadier, Foster's Seedling, Bramley, Gladstone, Annie Elizabeth, Newton Wonder, King Edward VII. and Graham's Royal Jubilee. 


\section{CHAPTER XIV.}

\section{THE PEAR。}

It used to be said by many fruit farmers that it does not pay to grow pears. However, some of the most skilful and successful growers at Crockenhill, Chart Sutton, and Teynham have young, promising pear plantations of pyramid or bush form budded or grafted on the quince stock, planted generally 9ft. apart on the square, with black currants or gooseberries between.

The varieties chiefly adopted, and which give most success grown in this way, include Willians' "Bon Chrêtien, Clapp's Favourite, Conference, Dr. Jules' Guyot, Doyenné du Comice, Catillac (Dec. to April), Fertility, Hessle or Hazel, Pitmaston Duchess (where this is found to succeed), Souvenir du Congrés, also Beurré Bosc, Louise Bonne of Jersey, Uvedale's St. Germain, (Jan. to April), Le Lectier (Jan. to Feb.), and Emile d'Heyst.

Early potatoes or mangolds are usually planted between, and sometimes Brussels sprouts or cauliflowers, but to grow the two latter without "drawing the land" needs heavy manuring, or it will be detrimental to the trees and bushes. Pears form an excellent avenue on the sides of the road through a plantation, or a wind break. For this purpose Hessle and Fertility have proved very suitable.

Even bush pears do practically nothing in the way of bearing for four years, but by eight years bear a good crop of handsome fruit.

The cultivation consists of digging in winter with the necessary pruning to shape the trees, with horse hoeing and about five hand hoeings during spring and summer. If pear scab appears on foliage or fruit, the trees should be sprayed while the leaf is off with copper sulphate or lime and sulphur, and just before the buds open and after the petals have fallen with Bordeaux mixture or lime and sulphur.

The spraying with lime and sulphur has also been found effective against
"Pear mite," which lives between the upper and lower surfaces of the leaves. The Pear Midge, which sometimes infests the interior of the fruit, making it useless, is often a serious pest; the affected fruits should, if possible, be picked and destroyed, and a dressing of kainit given to the ground below and around the tree.

Cross-pollination in pear blossoms is very important. It is therefore advisable to mix the varieties and keep bees, as it is found with many varieties that they will not set fruit if pollinated with pollen of the same variety. In planting avoid planting together a very early flowering with a very late flowering sort, alternate the variety every two or three rows. Conference seems to be a good polleniser for other varieties.

I once planted forty Pitmaston Duchess trees in a plantation away from other pear trees. For four years they blossomed, but set no fruit. I took them up and replanted them in another part of the farm, among a small plantation of other varieties of pear, and placed a hive of bees amongst, them. These trees that had been barren bore fruit well for several years whilst the bees were there, but now without bees they do not seem to bear so well, my successor does not favour bees.

In Worcestershire, and in some parts of Kent, one sees fine, tall, old pear trees, probably between 100 and 200 years old, still bearing small fruit.

The approximate life of a standard pear has been put at 70 years; its commencement of remunerative return, tenth year after planting; its period of best production, between 25th and 40th years; yield per acre when mature, up to six tons per acre; price per ton, $£ 7$ to $£ 28$ (pre-war).

The approximate life of a dwarf pear on quince is put at 20 to 50 years; commencement of remunerative return, fifth year; period of best production, 15th to. 
40th years; yield per acre when mature, five to seven tons in a good year.

Pears live to a great age in the orchards of Gloucester, Worcester, and Hereford; in the gardens of the Horticultural College at Versailles, I saw a splendid pyramid tree more than 200 years old.

With reference to monetary return from pears, in "Commercial Gardening," edited by John Weathers, published by the Gresham Press, in 1913, appears the following statement: "Pears on the pear stock vary greatly as to the time they. come into bearing after planting. Probably the planter will restrict himself to those varieties that come into bearing at the fifth year, when the produce may reach $£ 7$ or $£ 8$ per acre, going ultimately up to $£ 50$ or $£ 60$ an acre for a full crop. On the quince, by the fifth year the trees can make good show of fruit; if the soil is quite suitable a gross return of $£ 60$ or more an acre can be obtained in a good year, when the trees are ten or twelve year old, if proper care has been taken with the picking, grading, and marketing. The cost of picking will be found the same for apples and pears on dwarf trees with fair crop on, namely, from $1 \frac{1}{2} \mathrm{~d}$. to $2 \mathrm{~d}$. per bushel; on half-standard trees, from $2 \frac{1}{2} d$. to $4 d$. per bushel, according to denseness or otherwise of the under crop, and the consequent difficulty of working the ladders. Of course no hard-and-fast rule can be laid down; the prices are as variable as the amount of the crops. In mixed plantations of apples, pears, and plums, with average crop and conditions, the usual price is $6 \mathrm{~d}$. per bushel all round, including ' running' the plums where necessary." The above piece-work prices were paid pre-war, the picking now probably costs more than twice as much, and is most of it done day work. As a basis for argument as to the returns from a pear orchard, one may consider a carefully thought-out estimate of receipts and expenses of a pear orchard, given in "Commercial Gardening." The trees being planted 161 ft. apart, 164 trees to the acre, if the yield of each tree averaged two bushels-320 bushels, selling at say 3 s. 6 d. per bushel, the gross return would be $£ 56$ per acre. The expenses charged are rent, rates, and taxes, $£ 10$; 20 tons of manure at $6 \mathrm{~s}$. per ton, $£ 6 ; 10 \mathrm{cwts}$. basic slag at $£ 210$ s. per ton, $£ 15$ s.; cost of spreading manure, 30 s.; pruning, $£ 1$; hoeing, 50s.; picking 320 bushels at $6 d$. per bushel, $£ 8$; miscellaneous expenses, $£ 5$ $15 \mathrm{~s}$; ; total, £36. The yield of pears is, however, very variable in different seasons; frost, whilst the trees are in flower, especially if the blossoms are wet, may prove fatal to all blossoms open at the time; also windy, rainy, or cold weather at flowering time is detrimental, as it checks the working of the hive, the bumble and other wild bees.

The packing of pears is important. Whilst small, unripe pears can travel in bushels, the large ones need careful placing in half-bushels, with wood wool at bottom and top to prevent bruising; fine ripe pears are often wrapped individually in paper, and placed only two or three layers deep in box or basket, with a sheet of paper between each layer. I was told of $10 \mathrm{~s}$. being received for half a bushel of pears from cordon trees on a wall. Cordon pear trees are excellent against walls, and buildings may thus be utilised and beautified. In Jersey and Guernsey cordon pears are commercially successful on wire trellises, but for money making in England growing pears as cordons needs careful consideration, for fear it may not be remunerative.

As to varieties, Mr. William Miskin recommends for growing for market, from experience, in Kent, Dr. Jules Guyot, Conference, and Fertility, and perhaps Marguerite Marillat. The above mentioned work, "Commercial Gardening," lays stress on the fact that whilst in a garden one may aim at quality irrespective of quantity, in growing for market, if a variety crops well and is of good appearance though only of second or third-rate quality it may pay far better than a shy bearing or delicate first quality pear. Thus among the hardier pears, that crop fairly regularly, though their fruit is inferior, the Duck Egg (end of July); the Chalk (Aug.); and the Hessle (early Sept.), may be included among better varieties to be grown for market on pear stock as standards, these may be used as wind-breaks and along road sides.

Mr. Shackle, of Comberton, in Worcestershire, who grows pears for market 
somewhat extensively, finds the two varieties Fondante de Thirriot and Conference suit him best of many varieties tried.

The following is a list of

\section{Orchard Standard Pears}

recommended by the late $\mathrm{Mr}$. George Bunyard, V.M.H., given in approximate order of ripening:-Doyenné d'été (mid. to end of July); Crawford or Chalk (Aug.); Jargonelle (Aug.); Lammas (Aug.); Summer Crassane (end Aug. beginning Sept.); Hessle or Hazel (Aug. Sept.); Williams' Bon Chrêtien (Sept.); Dr. Jules Guyot (Sept.); Petite Marguerite (Sept.); Fertility (Sept.); Beurré de Capiaumont (Sept. Oct.); Durondeau (end of Oct.); Pitmaston Duchess (Oct.); Beurré Bosc (Oct.): Doyenné Boussoch (Oct.); Beurré Jean Van Gurt (Oct. Nov.).

Best market pears, as bushes on quince stock, recommended by $\mathrm{Mr}$. Bunyard, placed in approximate order of season for use:-Clapp's Favourite (Sept.); Petite Marguerite (Sept.); Williams' Bon Chrêtien (Sept.); Dr. Jules Guyot (Sept.); Souvenir du Congrès (end Sept. Oct.); Conference (Oct.); Louise Bonne of Jersey (Oct.) ; Princess (Oct.) ; Beurré Hardy (Oct.); Pitmaston Duchess (Oct.); Doyenné Boussoch (Oct.); Beurré Van Gurt (Oct.); Durondeau (end of Oct.); Beurré Superfin (end of Oct. Nov.); Emile d'Heyst (end of Oct. Nov.); Fondante de Thirriot (Oct. and Nov.); Beurré Clairgeau (Nov.); Doyenné du Comice (Nov., sometimes Dec.).

Pears Sultable for Cordons,

Petite Marguerite (Sept.); Williams' Bon Chrêtien (Sept.); Conference (Oct.); Loujye Bonne of Jersey (Oct.); Durondeau (Nov.); Belle Julie (early Nov.);
Fondante de Thirriot (Nov.); Doyenné du Comice (Nov. Dec.). Pears as cordons are suitable for walls, but in relatively few places in England are they to be recommended to be grown on wire trellises for market, the expense and uncertainty being too great.

Comparative order of Blossoming of Varieties of Pear grown for market.-See "Pollination of Orchards, The Flowering of Pears," by F. J. Chittenden, F.L.S., "Royal Horticultural Society's Journal," Vol. 39, 1913-14, pages 366 to 372, based on five years' observations at Wisley; take the date of flowering as that at which about half the flowers are open. The number represents the order in days:-

\section{Early.}

(1) Doyenné Boussock; (2) Doyenné d'été, Jargonelle; (3) Beurré Easter, Beurré Hardy, Citron des Carmes; (4) Passe Crassane, Verulam, Princess, Conference, Brown Beurré, Winter Nélis, Beurré Superfin; (5) Beurré d'Amanlis, Souvenir du Congrès, Beurré Giffard, Fondante d'Automne.

\section{Mid-F'lowering.}

(6) Marguerite Marillat, Durondeau, Fondante de Thirriot, Beurré Clairgeau, Petite Marguerite, Grosse Calebasse; (7) Uvedale's St. Germain, Louise Bonne of Jersey, Clapp's Favourite, Emile d'Heyst, Marie Louise d'Uccle, Beurré Jean van Gurt; (8) Triomphe de Vienne, Catillac, Fertility.

\section{Late Flowering.}

(9) Le Lectier, Williams' Bon Chrêtien, Belle Julie; (10) Hessle, Beurré Capiaumont; (11) Dr. Jules Guyot, Beurré Bosc, Marie Louise; (12) General Todleben, Glou Morceau, Doyenné du Comice; (13) Pitmaston Duchess. 


\section{CHAPTER XV. \\ THE PLUM AND DAMSON.}

The plum is a delicious and valuable fruit, but is rather irregular in bearing; sometimes the crop is short owing to frost or cold winds at blossoming time; at other times it is almost too abundant, and is liable to glut the market, in which case the prices are often very low.

The large importation of French greengages and German "Switchen" plum used to lower the price, so that our earliest plums, especially Rivers' Early Prolific, sold at a lower price than they otherwise would.

In the case of gluts in market, the general organisation of fruit distribution is at fault, and salesmen are partly to blame for not making sufficient enquiry to ascertain where the fruit would be readily saleable, when their own market is glutted. Sometimes while plums were being sold wholesale in one market at $\frac{1}{2} \mathrm{~d}$. per pound, in another part of the country within 100 miles, the retail price was $5 \mathrm{~d}$. or $6 \mathrm{~d}$. a pound, which limited the consumption among the working classes, and was prejudicial to the grower, as the high price lessened the demand for the fruit.

The plum tree thrives in most parts of the country, though some districts are especially favourable. Thus around Evesham and Pershore, in Worcestershire, it thrives specially well over a clayey loam containing plenty of lime. Lime is said to be important to all stone fruits. For market work, plum trees should only be planted on suitable soil, and on a site reasonably immune from frosts. Some growers prefer a S.E. and even N.E. aspect.

The trees chiefly planted are half-standards, the distance apart being 15 to 18 feet, according to the strength of the soil, with gooseberries, currants, or vegetables between.

At Pershore, egg plums are planted about $16 \frac{1}{2} \mathrm{ft}$ apart, Prolifies 18ft. and Manarch 21ft.
Plums do well planted and treated as bush trees, planted at a somewhat smaller distance apart. Plums are not well suited to the cordon system of cultivation, they do not approve of spur pruning.

The trees should be pruned into shape when young, for 5 or 6 years, after which the removal of large boughs is apt to cause gumming.

Among the manures in common use in the Evesham and Pershore districts may be mentioned soot, leather waste, bone and meat meal and shoddy.

Where plums are cultivated for market in Worcestershire, a good dressing of lime, say one ton per acre, every other year, is found to be very beneficial.

On soils requiring phosphates, superphosphate or basic slag should be supplied, and some form of potash where this ingredient is not in sufficient quantity for the soil. The varieties chiefly grown for market in Kent are Rivers' Early Prolific (the earliest English plum), Czar, Monarch and the ever faithful Victoria. In addition to these, around Evesham and Pershore the Pershore Egg, the Pershore Purple, Prune Damson and Belle de Louvain are grown. The Pershore Egg is cultivated in enormous quantities. One peculiarity of the Pershore Egg and Pershore Purple plums is that they come true from sucker, and are found very suitable stocks for other plums.

Some varieties, such as Rivers' Early Prolific, set their fruit better if there is a row of another variety planted, alternate rows or every second, third, or fourth row, to ensure perfect crosspollination.

In pollination trials with plums in the U.S.A. it was found that variety affinity exists, i.e., with certain plums one kind of pollen proves a better fertiliser than does the pollen of another variety; thus Mr. G. Sherrard, from trials 
at the John Innes Horticultural Institute, recommended for the pollination of the old greengage that Rivers' Early Prolific, Monarch and Czar were good pollenizers. Mr. George P. Berry, Fruit Expert to the Board of Agriculture, found that in Cambridgeshire, blocks of greengage trees fruited better when in proximity to Rivers' Early Prolific and Farleigh Damson.

As with the other fruit trees, it is recommended to plant two or more kinds of plum in an orchard, in alternate rows, or every second or third row, alternate rows ,probably being the best, apparently Victoria is the only plum that sets equally or almost equally with its own pollen. The flowers of Denniston's Superb are extremely rich in nectar, and is probably prolific due to its attractiveness to bees. The Pershore Egg Plum is strongly selffertile, and appears to be a good pollenizer for other plums, it is recommended as a good stock to work plums on as being itself resistant to "Silver Leaf."

The Pershore Purple, or Martin's Favourite or Purple Egg, was raised by Mr. Walter Martin at Pershore about 1877. The Purple Eigg Plum has all the advantages of the Yellow Egg Plum, but is also marketable when ripe, whereas the Yellow Egg's chief excellence is green for jam, canning, and cooking when green.

\section{The Flowering of Plums.}

In two years' record of the blossoming of plums, made at Wye, the average duration of flowering of the different varieties was 17 or 18 days, and the total duration of flowering of all varieties was about 25 days, so it is the early flowering and late blossoming varieties that are most likely to suffer from lack of cross-pollination, especially if the weather is unfavourable. An average from five records of the flowering of plums made in Kent, Hereford, Worcester, and Surrey was:-

Early Bloomers.-(1) The Japanese plums; (2) Grand Duke; (3) Damascene; (4) Black Diamond; (5) Prince of Wales; (6) Monarch; (7) Rivers' Early Prolific; (8) Czar; (9) Greengage; (10) Victoria; (11) Drooper; (12) Pershore Egg; (13) Pershore Purple.

Late Blooners.-(14) Bradley's King of Damsons; (15) Sultan: (16) Oullins
Golden Gage; (17) Prune Damson; (18) White Bullace; (19) Pond's Seedling; (20) Late Orleans; (21) Belle de Louvain.

Another point of great importance is to have bees in or within, say, a quarter of a mile to carry pollen from flower to flower, as from experiments with plums it is found that very few fruits will set if insects are excluded, and nearly half the varieties seem to be self-sterile, i.e., will not set fruit with pollen of the same variety.

Grease bands should be put on by the end of October, to catch the Winter Moth. The bands should be kept well greased till after the laying period of the female March Moth.

The quantity of grease required for 30 acres of rather close-planted plums in 1920-21 cost £60-i.e., £2 per acre.

Grease banding fruit trees was suggested by a clergyman in the neighbourhood of Evesham some 50 years ago ; it is found to require about a ton of grease to 100 acres of fruit plantation, or 3 ozs. per tree.

During February and March the trees are sometimes sprayed with lime wash. This has been found very beneficial in checking attacks of aphis, the queen mothers being killed. Lime spraying is especially beneficial to Czar, Monarch and damson trees, which are especially subject to aphis.

Arsenate of lead is used as a spray for caterpillars, whilst nicotine or soft soap and quassia or paraffin emulsion are used to destroy aphis, but the spraying to have most effect should be done as soon as the first aphides are seen, and before the leaves are curled.

If trees are subject to fungoid disease, such as "Mummified Fruit," or "Shothole Fungus," the trees may be sprayed with copper sulphate in late winter, or with Bordeaux mixture or lime and sulphur before the blossoms open, and when the fruit has set. Trees with "Silver Leaf" should be destroyed, as no certain remedy appears to have been discovered, and if an affected tree is allowed to remain in a plantation, the disease spreads with rapidity, especially among Victorias.

Old Damascene and Blue Diamond plums, if healthy, may be rejuvenated by heading the leading branches, as is the 
common method of treating damsons every five or ten years in Kent. This treatment would, however, be prejudicial to some kinds of plum.

Plums for market should be picked when dry, and before quite ripe, as they then travel best. It is advisable with a heavy crop to thin the trees two or three times, taking the largest and ripest fruits each time.

The Pershore plum is picked when both green and ripe, as it is used for cooking, bottling, and jam-making, and large quantities are now put into gallon and smaller tins in a heavy syrup and utilised by restaurants and caterers.

Plums in Kent used to be picked at $2 d$. to 4d. per half-bushel of 28lbs., and for picking damsons $5 \mathrm{~d}$. to $10 \mathrm{~d}$. was paid, according to crop.

Plums from our Kentish plantations are usually marketed in half-bushel baskets of 28 or 24 lbs.; whereas in Worcestershire pot baskets of $72 \mathrm{lbs}$. are used. Specially choice plums, however, are packed in chip baskets holding $12 \mathrm{lbs}$, each.

Damsons are often planted round a fruit plantation as a wind break, being seldom planted as a main crop. The Farleigh, or Cluster damson, is the variety commonly grown in Kent. As an example of change in price, the late Mr. Henry Staples, of Swanley, once told me that he had sold damsons in some years at $£ 1$ per bushel; in recent year's before the war the price was usually about $4 \mathrm{~s}$. per bushel, but it has again reached $£ 1$ in 1919.

Plums may be said to commence to be remunerative after their sixth year, and to be at their prime from their 10th to their 25th year. They usually live from 20 to 40 years, and when mature yield an average crop of from five to seven tons per acre, selling at, according to variety and season, from $£ 7$ to $£ 30$ per ton, this latter only for specially choice early sorts in a very scarce year.

The average return of an acre of plum trees is put at $\$ 60$ to $£ 80$ per acre by J.W. in "Commercial Gardening." Mr. Frederick Smith, of Loddington, once had 20 bushels of plums from a Black Diamond, but this tree is usually not a heavy cropping variety; 12 bushels of fruit were picked from a young Victoria tree, whick that year sold at 14s. per bushel.

$\mathrm{Mr}$. E. J. Honeyball, the well-known fruit valuer and land agent of Deal, most kindly gave me an estimate for a mixed plantation of half-standard apple and plum trees, planted alternately, with currants as an under crop, on medium land.

\section{Estimate for a Mixed Frutt Plantation IN Kent. (Pre-war). \\ Preparation per acre.}

Broad-sharing and cleaning $£$ s. d. $\&$ s. d.

land after previous crop, say

Ploughing and sub-soiling ...

Harrowing down twice .......

Setting out ready for planting

Planting (apple and plum 16:

by $16 \frac{1}{2}$, currants $5 \frac{1}{2}$ by $5 \frac{1}{2}$

feet apart)$$
110
$$

Cost of Trees and Bushes.

$\begin{array}{lll}1 & 1 & 0 \\ 1 & 4 & 0 \\ 0 & 2 & 0 \\ 0 & 4 & 0\end{array}$

$£$ s. d. $£$ s. d. 1,291 black currants at $12 \mathrm{~s}$

per 100

$$
\frac{7150}{1515 \quad 0}
$$

Add to this, cost of any manuring.

Mr. Honeyball added: "I can only give a general idea, but I have often heard it estimated that an acre of plantation costs $£ 30$. It makes a difference, of course, both in the planting and cost of trees and bushes, how many per acre you plant. For instance, gooseberries and red currants would be planted closer than black currants. The price of black currants has varied considerably in the last few years. During the last two years, healthy bushes, clean of mite, have made as much as 20 s. per 100 , whilst a few years ago 5 s. to $7 \mathrm{~s} .6 \mathrm{~d}$. was the value. Gooseberries were $8 \mathrm{~s}$. per 100 , but are now dearer owing to American gooseberry mildew; red currants $6 \mathrm{~s}$. or $7 \mathrm{~s}$. per 100 ; all at two years old." The price of trees is now double or treble and the cost of labour double.

A plantation such as the above used to cost fully $£ 5$ per acre a year to cultivate, without any appreciable return for the first three years, so that one may add $\$ 15$ at least to the cost of planting, and rent, rates and taxes. 
The cost of the trees is lessened by planting one-year-old trees, which is becoming a common practice in Cambridgeshire, as the maiden trees have more root in proportion to stem, and get a firm hold of the soil before they have top enough for the wind to affect them; and although at planting these trees look small, they go ahead of trees two or three years old when planted.

In a very good cherry orchard over grass near Faversham, plum trees (chiefly Victorias) were planted between the rows of cherries, and are now cropping well without taking up too much room. Rivers'
Early Prolific is found to grow well under grass.

Damsons were growing at Damascus at the commencement of the Christian era.

Damson stones are found in the relics of the Swiss Lake dwellings, but not plum stones.

Plums were grown in Italy in the Roman period, and enterprising Englishmen imported plum trees from Italy.

Victoria plums were also called Dauphin.

Greengage was introduced from France by a Mr. Gage, whose gardener having lost the label from a Reine Claude plum called the plum Greengage. 


\section{CHAPTER XVI.}

\section{CHERRY ORCHARDS.}

The cherry is only grown for market in certain districts, partly because it requires a certain climate and soil to thrive, and partly because there needs to be a sufficient number of trees to make it worth employing a man or boy to scare off the birds. Cherry trees do not thrive on wet land which needs draining.

In the North of Kent there are large, well-tended, productive, cherry orchards in the neighbourhood of Teynhan, Sittingbourne and Faversham, here they grow on a loamy soil, over clay, over chalk. In Mid-Kent there are extensive and good orchards around Maidstone and Malling on the favourable soil over-lying the Kentish ragstone, a kind of limestone. In Worcestershire, there are small cherry orchards around Tenbury.

Nearly all cherry orchards are under grass, experience with the cherry in this climate has taught this method, perhaps because cherry roots are shallow and they extend far around the tree. In Kent nearly all the orchards above 10 years old are under grass, it has been the practice to plant cherry trees in hop plantations, at 30 to 40 feet apart, cultivate the land, and tend the trees for about 10 years, then grub the hops and sow the land with grass and clover seeds suitable for permanent pasture. Cherry trees also thrive if planted out direct into grass land in the above districts, if carefully staked. planted, and protected. It is well to keep the ground to a distance of say $2 \mathrm{ft}$. or more from the tree cultivated, dug and hoed, for half-a-dozen years, rather than let grass grow up to the trees right away, as it would check the growth of the trees. A very important factor in the tending of grass orchards is the careful grazing by sheep, the aim being to have the grass evenly and closely eaten off, so that the grass of the paddock resembles a Turkey carpet. To belp the growth or fattening of the sheep and to manure the land, corn or cake, mangels or hay is given advantageously in moderate quantity. Basic slag is valuable to the grass and cherry trees; whilst salt will improve and make rough grass more palatable. Any thistles or stinging neetles coming up in the grass should be frequently cut over close to the ground, this discourages and checks them, and eventually gets rid of them.

A good deal of planting in grass is done in the West of England. A man who contracted for planting orchards in Worcestershire, around Tenbury, gave me the following estimate of

Cost of Planting Standard Trees on Grass Land to be Grazed by Cattue (Pre-War).

$$
\text { Per Acre. £ s. d. }
$$

48 trees, apples, pears, plums, or cher-

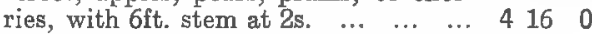

48 holes, $4 \mathrm{ft}$. across by $2 \mathrm{ft}$. deep, at

$2 d$. each (the distance apart being

$30 \mathrm{ft}$.

Planting (including pruning the head

and roots), at $2 \mathrm{~d}$. per tree $\ldots \begin{array}{ccccc} & \ldots & 0 & 8 & 0\end{array}$

$\begin{array}{lllllll}48 & \text { stakes, } 8 \mathrm{ft} . \text { long, at } 2 \mathrm{~d} . \quad \ldots & \ldots & 0 & 8 & 0\end{array}$

48 guards and fixing, consisting of 2in.

mesh, 6ft. high galvanised wire netting,* and 10 yards of barbed wire ( 4 barb thick-set) wound round spirally, at 1 s. $6 \mathrm{~d}$. each ... ... ... ... holes, carting trees, and placing a mulch of manure around each tree... $1144 \quad 0$

$£ 1016 \quad 0$

* Strong wooden tree guards, cost $2 \mathrm{~s} .6 \mathrm{~d}$. or $3 \mathrm{~s}$.
each, and last about seven years. For sheep
and rabbits, a $4 \mathrm{ft}$. length of galvanised wire
netting, $2 \mathrm{ft}$. wide, stood on end and fastened
around the trees is found to be sufficient,
and only costs $23{ }_{4}^{3} \mathrm{~d}$. per tree.

Horses and cattle are best kept out of an orchard; some horses are very destructive in an orchard.

At the National Fruit and Cider Institution, near Bristol, trials were made to 
ascertain the best treatment for apple trees planted in grass, as to size of circle to be kept cultivated, and for what length of time.

In Herefordshire, where cattle and horses are allowed in young orchards, the trees at 15 years old are found to have cost nearly $£ 1$ a-piece; this includes the cost of the trees, planting, strong and careful guarding and pruning.

The pruning of cherry trees should consist of shaping them when young, as severe pruning at any age is apt to be followed by "gumming." "Trees may be lightly summer pruned after the fruit is gathered, to admit light to the branches, in order to ripen the buds for next year, at this time also any dead wood which is now easily seen, may be sawn out.

The rent of a fairly good cherry orchard in Kent may be $\mathscr{L} 6$ or $\& 7$ per acre, whilst adjoining land not planted may let at 30 s. to 50s.; or a good cherry orchard may sell at $£ 150$ or $£ 200$ per acre, or even $£ 400$, whilst unplanted land adjoining, fetches $£ 50$ to $£ 80$ per acre. A cherry orchard in full bearing may rent at $£ 8$ to $£ 10$ per acre, or even $£ 12$. The annual expenses have been estimated at $£ 11$ to $£ 14$ per acre, and the yield from a good orchard $2 \frac{1}{4}$ to 3 tons of cherries per acre.

A relative, who has kept a record for 35 years of his cherry onchard, found it work out at an average gross return of $£ 16$ 2s. per acre for fruit, or an average of about 10s. per tree, plus the grazing of the grass by sheep and poultry.

Mr. Arthur Amos, M.A., who has had great experience, in an excellent chapter on "Cherries," in "Commercial Gardening " (published by the Gresham Press), says in a year when the crop is large an orchard may average 6 or 8 halves per tree, individual trees as high as 10 to 15 halves per tree, whilst when the crop is short it may fail to yield 1 half bushel per tree; the following is his estimate of an

\section{Average Cost of Production Per Acre}

$$
\text { (Pre-War) }
$$

Rent, $f 4$; rates and taxes, at $5 \mathrm{~s}$. in $£$ $\mathcal{E} 1$; manuring by feeding stock, $£ 1$; replanting 2 trees per acre, 6s.; grease banding, 7s. 6d.; spraying, 5s. : bird minding, labour and ammunition, 10s. Cost of production... £8
Gathering 160 halves, per acre, £6; packing and putting on rail, at $2 d$, \&1 6s. 8d. ; ailway carriage to market, $£ 213 \mathrm{~s}$. $4 \mathrm{~d}$.; return of empties at $\frac{1}{4} \mathrm{~d}$. per half bushel, $6 \mathrm{~s}$. $8 \mathrm{~d}$.; commission at 4 d., $£ 213 \mathrm{~s}$. $4 \mathrm{~d}$. Cost of $\begin{array}{llllllllll}\text { gathering } & \ldots & \ldots & \ldots & \ldots & \ldots & \ldots & £ 13 & 0 & 0\end{array}$

Total cost per acre £21 86

Estimating at 160 half-bushels per acre

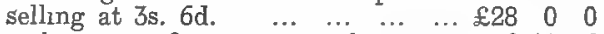
Leaving a profit per acre of $\begin{array}{lllllll} & \ldots & \ldots & 6 & 11 & 6\end{array}$

Increased expenditure ( $£ 34$ 15s.) per acre might increase the production up to 320 halfbushels per acre; decreased expenditure ( $£ 9$ 12s. 6d.) per acre, might decrease the production to 40 half-bushels per acre.

Mr. George Bunyard, in "The Fruit Garden," recommends planting cherries in an orchard in the order of their ripening, so that picking can begin at one end of the orchard and finish at the other end, to save unnecessary removal of tent, ladders, and other accessories. Flemish, May Duke, and Morello trees are useful for short rows, in corners, also as shelter from the wind in exposed positions, where they can be planted twice as thickly as the larger growing sorts.

The following are perhaps the best cherries to grow for market:-Early Rivers, Waterloo, Kentish Bigarreau, Napoleon and the Kentish or pie cherry.

At Ledbury, in Herefordshire, Governor Wood is one of the best varieties grown.

Many varieties of cherries are selfsterile, so one needs to take into consideration the planting of early flowering varieties near one another, some varieties are not inter fertile, others make specially good pollenizers, for information on this subject see Mr. Berry's article on "The Pollination of Cherry Orchards," in the journas of the Board of Agriculture.

Morello cherries are perfectly selffertile, and are less molested by birds than other varieties, and are quite a profitable cherry. I planted an acre of bush Morello, and the following was the approximate cost :-

Cost ot Planting Morello Cherries, Currants, and Strawberries, Per Acre. Pre-War. £ s. d. Ploughing, sub-soiling, and harrowing 1130

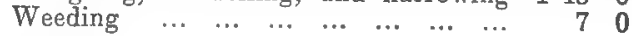


5 cwts. bone meal, at $5 \mathrm{~s}$. per cwt., put in holes dug for trees ... ... ... 135 two-year-old trees, at $135 \mathrm{~s}$. per 100 (distance 18ft. apart) $\quad \ldots \quad \ldots \ldots$ 1,075 currants at $7 \mathrm{~s}$. 6d. per 100 (at

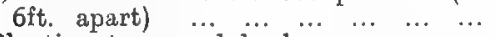

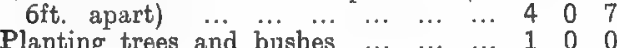
Strawberries planted between $36 \mathrm{in}$. by 18 ins.

$$
\begin{array}{llllllllll}
\ldots & \ldots & \ldots & \ldots & \ldots & \ldots & \ldots & 4 & 0 & 0 \\
\hline 21 & 7 & 10
\end{array}
$$

At the present time the cost of preparation of land would be about $£ 3$; the cost of bone meal 14s. per cwt.; and the cost of currants $£ 2$ per 100.

The Morello cherries were of bush shape, commèncing to branch about a foot from the $g$ ، ound. They were carefully, but lightly pruned every year, thinning out the slender branches. In gathering, the stems were cut by scissors by women, ai it was found that pulling brought away t.ie buds for next year. They were sent to market in gallon baskets, and sold well. When the trees were about 15 years old my successor told me that the cherries and red currants from this acre had yielded $f 60$ that year, but it was an exceptionally good year, whilst I had them the Morello cherries fetched about $4 d$. per lb. The order of ripening of cherries, as given me by Mr. Arthux Amos, is approximately as follows:-Early Purple Gean, Early Rivers, Adam's Crown Heart, Early Frogmore, Knight's Early Black, Black Heart, May Duke, Black Eagle, Flemish, Turkey Heart or Turk, Florence, Kentish Cluster or vrown, Morello.

The following gives an idea of the prewar prices of cherries per half bushel, of 24lbs. :-Kent Blacks, 3s. 6d. to 4s. 6d. ; Ambers, 4s. 6d. to 5s. 6d.; Frogmore, 3s.; Flemish, 4s.; Black Eagles, 5s.; Waterloos, 6s. to 7s.; Napoleons, 7s. to 10s.; Turks, 7s.; Florence, 6s. 6d.

The order of flowering is approximately, Early:-Old Black Heart, Rivers' Early Black, Adam's Crown, C'orone, Turk, Governor Wood, Elton.

Late-Black Eagle, Knight's Early Black, Waterloo, Frogmore Bigarreau, Amber Bigarreau, Rivers' Bigarreau, Florence, Napoleon,' May Duke, Morello.

My observations for a few years showed cherries of different varieties were in flower an average of 22 days, being in full flower on the 7 th or 8 th day after commencing to flower.

There are two leaf diseazes that injure the cherry, also black aphis and cherry slug are sometimes troublesome. 


\section{CHAPTER XVII. \\ COB AND FILBERT NUTS.}

The growth of cob and filbert nuts for market is very local, although one sees a few nut trees in gardens in many, if not all, parts of the country. Around Ightham and Wrotham and in the neighbourhood of Maidstone, in Kent, one may see nut plantations of two to ten acres, one grower has fifty acres, some of the trees being 100 years old, and still cropping well In Kent it is over the Kentish Rag Stone that the nuts thrive best; this rock disintegrates into a somewhat loose subsoil, providing good drainage and supplying plenty of lime.

A large proportion of our nut crop is exported to the United States.

Nut bushes take some time to come into bearing, probably five to ten years before they can be called remunerative, they are said to commence to be remunerative about six years after planting, to be at their best from about their fifteenth to their fiftieth year, and on suitable soil to last 60 or more years. The crop and price vary greatly, an average may be 7 to $8 \mathrm{cwts}$. per acre, and an average prewar price $£ 30$ per ton. Mr. G. Smith in 1897 grew 100 tons of nuts on 100 acres, and once grew up to two tons per acre.

Mr. George Smith, the late well-known and popular land agent and valuer of Loddington, near Maidstone, gave me the follow'ng as his estimate of the cost of planting nuts, and their return when mature, with cost of cultivation.

Approximate Cost of Planting Nuts WITH GOOSEBERRIES OR CURRANTS.

(Pre-war).

Ploughing and harrowing £ s. d. Setting out land for planting Digging holes and planting (194 holes being 15 feet apart, 18 inches square, taking out soil 6 inches deep, and loosening the subsoil another foot in depth)
194 four-year-old Kentish cob nuts at 20s. per 100 11810

Digging holes and planting gooseberries or currants at 5 feet apart ........... 1,548 gooseberry bushes at $12 \mathrm{~s}$. per 100, or currants at $8 \mathrm{~s}$. per 100, for average say, 10s. per 100

Mulching nut trees with four loads dung, with labour

It is a common practice to plant apple or plum trees between the nutsbeing planted on the triangle system $(. \cdot)$; this is somewhat of a disadvantage to the nut bushes. The disadvantage, however, is lessened by planting varieties of apple or plum having an upright habit rather than those that spread. By mixing the fruits, the money return from the planbation is found to be more regular.

Gooseberry bushes may be planted between the trees, and for one or two years potatoes may be grown between these.

\section{Mature Nut Plantation.}

Cost per ACRe for Cultivation.

$$
\text { (Pre-war.) }
$$

November or December, 1 ton shoddy, with labour, $f 3$, alternate years, half cost

Digging with fork

December or January, grubbing out spawn at root ...........................

February, pruning at 10s. per 100 trees March, Canterbury hoeing April to September, 3 or 4 hoeings ... September, picking (in three pickings), $850 \mathrm{lbs}$, at 2s. per 100lbs. ...............

Carriage, say ...................................

Commission, $7 \frac{1}{2}$ per cent. on $£ 143 \mathrm{~s} .4 \mathrm{~d}$.

Rent, tithe, rates, taxes £ s. d.

1100

$\begin{array}{lll}0 & 18 & 0\end{array}$

$\begin{array}{llll}0 & 3 & 0\end{array}$

$\begin{array}{lll}1 & 0 & 0\end{array}$

$\begin{array}{lll}0 & 4 & 6\end{array}$

$016 \quad 0$

$\begin{array}{lll}0 & 17 & 0\end{array}$

$\begin{array}{lll}0 & 10 & 0\end{array}$

$\begin{array}{lll}1 & 1 & 3\end{array}$

4 C 00 
Return.

Receipt, say, 850lbs. at 33s. 4d. per

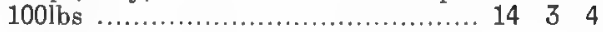

Balance, profit ........................... 337

If apples or plums are grown between the nut trees the money returns will be larger, though if they shade the nut bushes the crop of nuts will not be quite so good as if in full sunshine.

Crops, as well as other things, are in. fluenced by fashion; people either have not the leisure, or have lost the habit of sitting over " nuts and wine" after" dinner, in the way their grandfathers did; so there is not quite the demand for these nuts that there used to be, and nuts are not planted now as much as, say, fifty years ago. Kent cob and filbert nuts, however, generally fetch a fair price. They are rather irregular in cropping, sometimes there being a good quantity, and at other times very few. Their annual cultivation, however, is not very expensive, though they take some time to come into bearing.

Cobs are chiefly grown because they crop more heavily than filberts, the latter are, howcrer, the nicer nut.

As the seedling growing from the nut is not "true" to its parent, but inferior, the general method of raising the young plants is from suckers, or by grafting upon stocks of the common nuts, which are nlanted from 10ft. to $15 \mathrm{ft}$. apart, and are in Kent trained to a shape resembling that of an umbrella point downwards, there being a clear stem of 12 or 18 inches, from which five or six branches spring. These are sometimes pegged down, or may be trained at first by a hoop, to keep the bush open in the centre to air and sunshine, somewhat in the way red currants are trained. The trees eventually reach six feet, which height they are not allowed to exceed, so as to be within reach for pruning and gathering, they are yearly trimmed to encourage fine wood that bears nuts.

All "wands" or uprigh growing twigs are taken out at the base by a sharp pull; this is better than cutting them out with a sharp knife, as when (ut, young buds form and sprout into new shoots, whereas it pulled out or sawn the rough wound does not form buds. These wands make good "splints" for packing apples and other fruits.

An important operation during the winter is to grub out with a mattock or "suckering iron" all the suckers that come up from the roots.

Shoddy is still largely used for nut plantations, applied in alternate years. When the trees are cropping well nitrogenous manures suit well, including nitrate of soda.

Cob nuts are in flower from early in January to mid-February, the male and female are separate blossoms, the male or pollen bearers being the catkins, the female being pretty little red stigmas, which later on develop into the nuts. The pollen is carried to the stigmas by the wind, it is important, therefore, to leave the pruning of the twigs carrying catkins till they have shed their pollen. Mr. George Bunyard, of Maidstone, told me that in many plantations a variety of cob, known as the "Cosford" is specially planted here and there, as it is a plentiful producer of pollen.

Pruning cob and filbert nuts is a speciality in Kent, and men who can prune these trees can earn high wages for their work, and sometimes travel to other parts of the country (usually called "the Shires" by their relatives.) to prune nut bushes. Careful growers summer prune the trees early in August. Harvesting nuts will be dealt with in another chapter.

\section{The Walnut (Juglans Regia).}

The walnut is a valuable tree, being remunerative "when it comes of age," for its nuts, and if cut whilst the trunk is sound its timber is in great demand for furniture, gun stocks, fretwork wood, ete.; it is withall a very handsome tree. Its botanical name is Juglans, glans meaning nut, Joris-of Jupiter; it is thought to have been introduced into Britain by the Romans. In Southern Europe this tree lives 300 or 400 years. At Great Canfield, in Essex, a recent report says there is a tree thought to be 350 years old, the girth of the trunk being 13ft., and the spread of its branches is 100 feet in diameter. A single tree, under the most farourable 
circumstances is considered to yield up to 60 bushels of nuts; the ordinary arerage yield is said to be 6 or 7 bushels. A relative near Faversham has kept a record of the nuts sent to Covent Garden from two walnut trees during 29 years, it amounted to 330 bushels of nuts, which sold for $£ 66$ 10s. 6d., giving an average of $11_{2}^{1}$ bushels per year, at an average price of $4 \mathrm{~s}$. per bushel, being £2 $5 \mathrm{~s}$. 10d. per year, or 22s. 11d. per tree. In 1919, the nuts of the two trees sold foi $£ 10$ at $2 C \mathrm{~s}$. per bushel. One tree is a soft-shelled variety, having a hen run under it (which manures it well), the other tree near by is a hard-shelled variety; the trees are thought to be 70 to 80 years old, such trees (pre-war) would be worth $£ 5$ or more as timber.

On some fruit farms one may see single rows or avenues of walnut trees which are yearly beaten for their nuts, the beating knocks out dead wood, and it is a proverbial saying the more you beat the walnut tree the better it yields. For beating off the ripe nuts in the autumn long supple ash rods are used from long ladders.

Walnut trees to grow well are considered to need lime in the soil, and if lime is known to be deficient as in most clay and sandy soils, a barrowful of chalk may be put in the hole and well mixed with the soil before planting.

A large proportion of the crop is gathered green for pickling, being picked in the first or second week of July. The following is a Recipe for Pickling, given by W. P. M. in "Food," July 12, 1917.

"The nuts should be picked when green before they have attained full growth, and when still soft. Prick each all over with a large needle, and place in strong brine, formed of $11 b$. salt to every half-gallon of water. Leave the nuts in this for four or five days, then transfer to fresh brine for a similar period. Take out and leave in the sun, spread out on trays, till they turn black. After placing in bottles pour over them boiling vinegar in which has been boiled an assortment of spice. A good mixture of spice is:--One teaspoonful of cloves, 2 tablespoonfuls of peppercorns, 3 tablespoonfuls of allspice to every quart of vinegar. Strain before pouring over the walnuts, cork and seal the bottles and keep them for a couple of months before use."

A bushel of walnuts in the husk weighs about 40lbs, and yields about half a bushel of nuts, containing about 1,000 nuts.

A considerable proportion of the walnuts that come to England from the Continent have been washed and put in a kiln with sulphur, which kills the life germ of the nut, they therefore keep better than the English walnuts.

The walnut does not come "true" to its seed; seed should, however, be chosen from a good variery. The thin-shelled English walnut is considered a good sort to sow, but it does not always come true. Grafting is the only way to keep a variety "true." Of the large soft-shelled French varieties, the following are among those most recommended at present for planting in France:- "La Tranquette," the "Mayotte," and the "Parisienne."

The late Mr. George Bunyard wrote that the large French walnut succeeds in the warmer parts of England, but unless the summer is a warm one, the nuts which are very large do not ripen well, the edible part being only half-formed.

Among the English varieties are "High Flyer," "Large Double," and "Thin Skinned."

The planting of the English walnut is recommended by authorities for road-side planting where soil, etc., favour, being both useful and beautiful.

The pollination of walnuts is commercially worth consideration. A walnut tree planted alone will probably not bear fruit as wcll as where there are two trees (preferably of different rarieties) planted near enough for the wind to carry the pollen from tree to tree, and thus effect crosspollination. Professor E. J. Wickson, the horticultural lecturer at the University of California, writes as follows in his excellent book, "Californian Fruits":"The walnut has its staminate and pistillate blooms separate, but both occur on the same tree. Successful fruiting depends upon the appearance of these two forms of bloom, without too great interval of time, and although there seems to be quite a retention of vitality, the lack of bearing of some varieties has been found due to the fact that the catkins disappear too 
long before the pistillate bloom was sufficiently deviloped to receive the pollen."

\section{The Spanish or Eating Chestnut.}

This tree belongs more to the park and the forest than to the farm. In sowing seed of this trec it would scem to be advisable to choose the finest and largest nuts procurable as seed, so as to have a yield of large nuts, rather than tiny, almost worthless ones.

The propagation of the Spanish chestnut is generally areomplished by sowing seeds, and by grafting and budding. Sieed is gencrilly sown in October or Noxember, in drills forr inches deep and six inches from seed to seed, and about two feet apart in the rows. At the end of the first year the young trees are plintod into nursely beds, three feet apart, and two feet from plant to plant, where they remain for another year, after which they are plantod into permanent quarter's. If the trees are wanted for their fruit they are generally grafted, the scions being taken from good nut-bearing trees and grafted in the ordinary method, upon scrullings of two or three years old. If well-grown specimens, thi young trees flower the noxt spasoll. The soil best suited to the chestnut is a light, moderatcly rich sandy loam, and in these positions, if well looked after (due attention bring paid to the selection of grafts, as with other fruits), there is no reason why they should not be brought into early braling in this comntry, and thus larger fruit obtained for market use. In market, buyers will not look at English-grown rhe'stnuts, owing to their small size and being able to buy large quantities of the fine "Redon" walnuts from France.

Southern France and ipain produce large nuts, used there as a staple food; they are also exported largely to England in sacks. The French make a swectmeat from the chestnuts by crystallization in sugar, known as Marons glacés. The timber of the sweet chestnut is almost equal in durability to oak, whilst where it is grown in woods for coppice it provides splendid stakes for fencing, very suitable for fencing fruit plantations, the stakes being driven in between two wire rope strands strained and twisted. 


\section{CHAPTER XVIII}

\section{PICKING, GRADING AND PACKING.}

\section{By Cecil H. Hooper and Ernest M. Bear.}

The grower's financial results depend very much on the care he gives to the marketing of his fruit. There has been considerable improvement in this respect of recent years, but there are still plenty of growers who are standing in their own light by continuing to follow slip-shod methods, as a visit to any of the big markets will prove. There is not the slightest doubt that it pays well to secure a reputation in the market for fair and honest packing, whilst good grading of fruit that lends itself to the process always brings its reward in the shape of higher returns.

Honesty is the keynote in packing. Buyers are naturally pleased when they find they can rely on getting full weight, with the fruit just as good at the bottom of the basket as it is on the top laver. Yet many growers are content merely to fill the baskets more or less level with a mixed sample. Such haphazard methods must go, together with the old discredited plan of "topping up" with the best fruit, which does not deceive a buyer more than once. All fruit should be weighed, no matter whether it is picked in the field or in the packing shed. There is a recognised market net weight for a bushel or half-bushel of each kind of fruit, and it i. not much trouble to see that this weight is packed, although the baskets, unfortunately, vary in size a good deal. For instance, any half-bushel of plums should be adjusted to weigh $31 \frac{1}{2} l b$, which allows 281b. for the fruit and $3 \frac{1}{2} 1 \mathrm{~b}$. as the average weight of the empty basket.

For all fruits that lend themselves to it, especially for apples and pears, grading $i_{i s}$ profitable. Apples graded into firsts and seconds realise more than the same fruit sent to market as a mixed samplo. In many cases the seconcis make as much as the mixed sample would, whilst the firsts realise a good deal more. One has only to try the experiment to see at once that both big and little apples look much better when sorted into fairly even sizes. and packed separately. The chances are that even the seconds will look much nicer than the original mixed sample.

In addition to care in grading and fairness in weighing, appearance should be studied. Clean wood-wool and coloured tissue paper look much better than mouldy hay and old newspaper. It pays the grower to present his fruit in attractive form, just as it pays the retailer to expend time and trouble on window-dressing.

\section{Picking.}

If fruit is to be well packed, it must first be carefully picked. Knocking or shaking down from the trees will not do nowadays, because it is bound to bruise the fruit and lower its value. For picking from bush-shaped or half-standard trees steps are needed. A handy form of steps, which can be made by any firm of laddermakers, or even by local carpenters, is wide at the base and pointed at the top, where a pole is hinged to form the supporting leg. These stand firm on uneven ground, particularly if the leg is shod with an iron spike, whilst the pointed top is easily got between the branches. The most convenient size is $6 \mathrm{ft}$. 6in. high and $2 \mathrm{ft}$. 3in. wide at the foot, fitted with severs steps. Taller steps are heavy to lift about, but a few pairs are useful for trees that are high and yet not strong enough to support ladders.

For standard and other tall trees ladders are a necessity. Special fruitpicking ladders are sold. These are wide at the foot and taper to a point at the top. sc that they are light to lift about and hancly to push up into the tree. 


\section{Packing Methods.}

With strawberries, the points the grower has to be constantly on the lookout for are that only ripe fruit is picked, that it is picked with a short strig, and that the inuit is not crushed; it is either picked into handle baskets of about a gallon, and then transferred to pecks, or direct into the peck; the greater part of the Kentish strawberries travel in pecks, which should hold 12lbs. of fruit. The English-made pecks ar'e generally uniform in size, but those from Holland, although cheap, are of all sizes, holding between 10lbs. and 16lbs., and are, therefore, very unsatisfactory to everybody. Some strawberies are sent from Kent in 4 or $6 \mathrm{lb}$. packages, but the Kentish railway rans are probably the worst in the king- clorn for fruit, as they are badly ventilated, have no shelves, and should have their roofs painted white to keep them cool. The Southampton district picks its strawberries into handle baskets of about 4 lbs., and the railway company serving this district provides trucks fitted with suitable shelves; these handle baskets have paper over the fruit, but strawberries in pecks are found to travel best without any paper. Cornish strawberries, being early and at a long distance from market, are sent in punnets. For jam, strawberries are picked leaving strig on plant ("plugged"), and placed in tubs containing 14 to $401 \mathrm{bs}$.

Raspberries are nearly all picked without strig, and placed in 4ib. gallon baskets. Those previously used for the Southampton strawberries answer well. The bulk is put in tubs ready for the jam factories. The price is usually better for basket fruit, and if not wanted for dessert can be shot into tubs in market. For small quantities of raspberries for jam making, empty lard buckets could, previous to the war, be bought from the grocer for $4 d$. each and make good packages. The very finest raspberries with strig, also the finest red and white currants, sometimes sell well in punnets or other small packages.

Children, if careful, make excellent raspberry pickers. Their fingers are light and do not crush the fruit, and their eyes bright to see the fruit on the lower branchlets.

Green gooseberries travel well in half- bushels of $281 \mathrm{lbs}$, or from some districts they are despatched in' sacks. Ripe gooseberries being tender, travel better in pecks.

Red and black currants are chiefly sent away in halt-bushels, with a sheet of blue or pink paper over the top retained by cross splints; all leaves should be picked out; the finer red and black currants, especially if ripe, travel better in pecks.

Cherries must have their strigs. They need careful picking and packing to exclucle any split or mouldy cherries; the hall-bushel covered with paper is the usual package, with two "splints" of nut wood to keep the fruit in. In picking Morello cherries the strigs are apt to pull out the buds that should bear fruit next year, so with this variety on bush trees it is advisable to cut the strigs with scissors. These cherries sell well in gallon or neck baskets.

The chief package for Kent plums is the half-bushel, or, for choice ripe ones, the peck. A few of the best dessert plums often pay for packing in chip baskets with handles. In packing half-bushels or pecks no litter should be used, nor should the baskets be lined with paper, which hinders ventilation. The plums are simply filled in to the correct weight, and a piece of tissue paper tucked in over the top and held in place by two crossed binders.

The greater part of the Kentish apples are despatched in bushel and half-bushel baskets, for cooking and dessert varieties respectively. The fruit can be picked direct into bushel or half-bushel baskets. In order to avoid bruising it is a good plan to place some wood-wool at the bottom of the basket and a strip of corrugated brown paper round the inside. Picking baskets are made, lined with felt. For gathering apples by ladder a picking basket with handle is generally used, as it can be hooked to a rung of the ladder. Some gatherers use a sack slung under the left ar'm, having a slit in the sack where the fruit is put in. A modification of this used considerably in Australia and copyrighted on the Glewston Fruit Farm, is a sack which has a flap at the bottom which one can detach in order to let the fruit run out. Some growprs use barrels for conveying cooking apples.

When the apples have been gathered 
they should be carted to the packing shed, which, for convenience in grading, should contain a bench or table with ledges round the edges to retain the fruit, the whole covered with sacking or carpet to prevent bruising. If sorted in three qualities and waste, the first and second are sent to market, the third kept at home, and sold locally or made into apple jelly or cider. Grading cooking apples is done entirely by size, except that any specimens disfigured by scab or misshapen are kept out of the firsts and put into the seconds or thirds, according to the extent of the blemish. In the case of dessert varieties, colour is quite as important as size, and the firsts should include none that are not well coloured and of good shape. Apples that are cut or badly bruised should never be sent to market, but placed in the thirds with the very smallest.

Before starting to pack, the baskets should be prepared as follows: (1) Line the sides with a strip of stout packing paper; (2) place a thin layer of wood-wool or clean hay on the bottom; (3) lap over the sides two sheets of tissue paper, using pink for firsts and blue for seconds. This paper should reach the bottom of the basket, but there must be enough overlap to cover over the fruit when the basket is full.

Having prepared the baskets, the apples can be graded and packed into them direct from the heap on the table, the packer having a basket for firsts on one hand and one for seconds on the other, with a receptacle for thirds somewhere handy. The fruits should be packed in one by one in layers, starting each layer round the outside of the basket. Some apples look best on their sides, others eyes upwards. When a basket is full it is put on the scales and the weight adjusted (20lbs. net for halfbushel, 40lbs. for bushel). The overlapping tissue paper is then folded over the top and tucked in, a little wood-wool or hay laid over that, and the whole secured with crossed benders, the points of which fix under the rim of the basket.

Salesmen, from my own experience, do not generally encourage English apple growers to pack in boxes, and prefer their own baskets being used, but non-returnable, standard-sized, half-bushel boxes for finest apples of certain kinds will probably become popular for English apples eventu- ally. Growers now have the opportunity of seeing expert apple packers give demonstrations in the box packing of apples at the Kent and other county fruit shows. It is a skilful job and needs practice.

Pears are largely sent to market unripe in bushels and half-bushels packed as described for apples. Any ripe ones are wrapped in paper and carefully packed in peck baskets. They should never be allowed to become quite ripe before being marketed. They travel better if unripe, and retailers like to have them ripen gradually after they receive them, otherwise many go rotten before they can be sold. Choice dessert pears of perfect shape pay for packing in single-layer boxes holding 1 doz. or 2 doz., the fruit being nested in fine wood-wool.

In outdoor tomatoes, of which the ripening is largely finished in glasshouses, the peck of 12lbs. is the standard package.

\section{Cost of Fruit-Picking.}

The following gives some idea of the cost of fruit picking in Kent, but, of course, varies with crop and other conditions.

Previous to the war, picking strawberries cost $3 \mathrm{~d}$. to $5 \mathrm{~d}$. per peck of $12 \mathrm{lbs}$, now 6d., but much of the picking is done "day work." $\frac{1}{2} \mathrm{~d}$. per lb. used to be paid per" lb. punnet or without strig for jam.

Raspberries cost now 1d. per lb. to pick in place of $\frac{1}{2} \mathrm{~d}$.

Gooseberries (green or ripe) used to cost $4 \mathrm{~d}$. to $5 \mathrm{~d}$. per half-bushel of $281 \mathrm{bs}$.; now $9 d$. to $1 \mathrm{~s}$.

Red currants (with strig) used to cost $5 \mathrm{~d}$. to 8d. per half-bushel of 24lbs.; now $1 \mathrm{~s}$. to $1 \mathrm{~s} .6 \mathrm{~d}$.

Red currants (without strig), for jam, used to cost 10d. to 1s. per half-bushel of 28lbs.

Black currants (with strig) used to cost $6 \mathrm{~d}$. to 1s. per half-bushel of 24lbs., $\operatorname{col}$ (without strig) 1s. 3d. per half-bushel of 28lbs.; now $2 \mathrm{~s}$. $4 \mathrm{~d}$, to $4 \mathrm{~s}$. with strig.

Cherries, $6 \mathrm{~d}$. to $8 \mathrm{~d}$. per half-bushel of 241 bs. : now 1s. 6rl, to $2 \mathrm{~s}$.

Plums, 2d. to $4 \mathrm{~d}$. per half-bushel of $28 \mathrm{lbs}$. Damsons, 5d. to 10d. per half-bushel of 28lbs.: now 9d. to $1 \mathrm{~s}$. $6 \mathrm{~d}$.

Apples (large or small), 1d. to $3 \mathrm{~d}$. per bushel of 40 to 50lbs. ; now $3 d$. to $5 d$.

Pears, 4d. per bushel of 40 to 56lbs. 
Cob and filbert nuts, $1 \frac{1}{d} \mathrm{~d}$. to $3 \frac{1}{2} \mathrm{~d}$. per perek of 7lbs.; now $3 d$, per 1001h.

The cost in 1920 was nearly double the pre watr cost.

\section{Thinning Fruit.}

In most seasons some varietics of apples, pears, and plums set more fruit than they ought to carry. If all of it is left to ripen the strain on the tree is so great that it often requires a year or two in which to recover before it can bear another crop, beside which growth is checked, and branches often break under the weight of fruit. Moreover, an overcrowdedcrop is generally composed largely of small fruit which are not of the highest value. In rear's of plenty in particular, none but apples and pears of good size realise the top price, this referring especi- ally to cooking apples. It has been proved that thinning increases the proportion of firsts and secures an enhanced financial result over a series of years. To be of much service thinning must be done early, preferably in June. Generally it is sufficient to thin apples and pears to one fruit to a cluster, removing, of course, the smallest and any that are diseased or blemished. Sometimes, if the clusters are far apart, two fruits may be left at each. On the other hand, if a very full crop has been set, all the fruit should be taken from some clusters, leaving the apples or years about 8 inches apart. The thinning of plums is generally left until the fruit removed is large enough to market green; and for this a higher price is som stimes realised than for the ripe fruit later in the season. Plums should be left four inches apart. 


\section{C'HAPTER XIX.}

\section{A DIARY OF A FRUIT FARIMER.*}

JANUARY -C Cart dung, and when frosty wheel dung, shoddy, fur-waste, fish guano, etc., on to gooseberry, currant and raspberry plantations. A horse-drawn trolley can advantageously be used in fields of raspberries (wheeling out and spreading dung on rasps. used to cost about 12s. per acre before the war). Cut out old (anes, and thin young canes in raspberries, dig up "spawn," hoe, and dig, or plough. (Digging raspberries cost about 20s. to $24 \mathrm{~s}$. per acre pre-war). Prune gooseberrics, red and black currants, clear prunings, hoe out and dig, Prune apples, take any dead wood out of cherries, clear up prunings. Dig strawberry plantations, Stake fruit trees. In bad weather', lime-wash stables, poultry houses, pig-styes, etc. Make splints for packing fruit; make boxes for fruit. Sort and pack apples.

February.-Cart and spread dung. Hoe young and old raspberry plantations. Dig up "spawn" if required for planting young plantations or for sale (for which work 1s. 6 d. per 1,000 was paid pre-war). Cut out old cane from raspberries, tip canes, and carry off, costing 2s. to 3s. per acre (pre-war). Fish salt is good for raspberries, fish guano for gooseberries, black currants and raspberries. Plant raspberry plants (only using young spawn), cost of planting 15s. per acre (pre-war). Plant gooseberry cuttings., Ring hoe gooseberries and currant bushes (5s. per acre pre-war). Prune gooseberries and currants; dig the plantations (24s. to 28s. per acre pre-war). Prune apples, pears, plums, Morello cherries. Re-touch grease bands. Scrape bark and lime-wash trunks of old fruit trees, or spray with caustic potash or soda, or with lime-wash (1lb. lime to 1 gallon water), cleans trees

\footnotetext{
*These notes are based on Labour account books kept by the writer at Highlands Farm, Swanley, Kent, for about 10 years, with the addition of further notes.
}

of mussel scale and other insect pests. Spray trees that were last year attacked by "scab" or "brown-rot" with copper" sulphate or lime-sulphur wash. Cut off shoots of apple wanted for grafting, place in earth near a north wall. Black cotton may be threaded among gooseberry and currant bushes to keep birds from pecking the buds. Soot and lime dusted over the bushes deter the birds, repeat the dusting when washed off.

March.-Top raspberry canes (2s. per acre pre-war); complete planting raspherries. Hoe round and dig raspberries (27s. per acre pre-war). Get up strawberry runners, mark out land, and plant (if marked out by line), treading ground each side of line (cost 5 s. per acre, planting 16s. per acre pre-war); if marked by machine, roll land lightly after planting. Plant cuttings of gooseberry, red and black currants. Where raspberry plantations have been ploughed, "spuddle" (i.e., dig lightly between the plants in the row with a fork), cost 9s. to 10s. per acre prewar, taking out any couch which should be put in a bucket and carried off. Graft plums. Lime-wash apple and plum trees, which kills apple sucker and plum aphis, or spray with lime-sulphur just before leaves and blossom buds open. Finish digging all plantations and commence hoeing. Canterbury pronged hoe is a good tool for first time through, it levels the ground (cost 4s. 6d. per acre pre-war). Finish planting strawberries, raspberries, bushes and trees.

APRIL.-Great month for hoeing. Where raspberries have been ploughed run a heavy two-horse brake through raspberries with boy leading. Rolling may be advisable afterwards, using a horse with a small rib-roller (specially made for the purpose), or a garden roller. Fill up where any strawberry plants have failed. Hoe strawberries (first time used to cost 


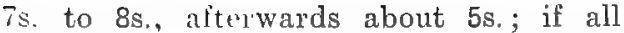
wromul hand hoed among young strawlurrics, 14s. W'r acre pre-war). Edge hoe rasplberics, cost $6 \mathrm{~s}$, per acre pre-war. Flat hoe whole of bush plantations (gooseberly, black and red ('uriant), cost 10 s. per acre pre-war. Fork out any dandelions or docks among strawberries. Run single zig-zag harrow between raspb?ry rows to make the soil fine. Horse hoe roung strawberries with great care. If clung litter is used (straw is cleaner) to litter strawberries, commence carting, it requires 12 or 13 loads per acre. Apple trees subject to "scab" should be spraycd with Bordeaux mixture, or limesulphur wash, just before blossoms open, and just after petals have fallen with addition of lead arsenate in either case to poison caterpillars. Pear, quince, plum and ch'rry trees should be treated similarly if they are respectively liable to "scab," "brown-rot," or other fungous discreses or catcrpillars. Finw wallflower seed.

Mr.r.-Horse-hoe newly-planted raspberies and old plantations. Fork out any couch-grass among raspberries. Horst; hoe strawberries. Edge-hoe strawberies ancl raspberries. Hoe bush plantations, if wide enough by horse, in two directions, if not wide 'nough hoe by hand. Cart straw (preferably barley straw) lor littering strawberries. Hoe strawberries extra carefully last time before litteling (cost 7s, per acre pre-war); cut l'unners. Litter strawberries when they commence to flower. Littering with barley straw takes about 1.1 loads per acre. May 18th -C'ommenued picking largest green gooseherlies at $6 \mathrm{~d}$. per peck pro-wal. Feed fruit trees atter fruit has set, mulching with dung litter. Pick off "big bud" on black currants (2d. per quart upwiruls). In 'ase of aphis on plum or black aphis on ehery, spray with soft soap and quassia, or a reliable proprietaly wash. Wher" liable to "scab" on pear or "apple, or "brown-rot" on therries or plums, spray again a third time with lime-sulphur, with lead arsenate. Nulphur stramberry plants if liable to mildew, using a knapsack" powder pump.

Jt゙xF, - Hoe strawberries; cut runners; Iitter: straw littering cost about $7 \mathrm{~s}$. $6 \mathrm{~d}$.
Hol acre prewar. Pick green gooseberres, thinning the fruit on the bushes, cost 2!d. per peck pre-war. June 5thCommenced picking strawberries (4d, per peck, for bulk, ?.2 d. per lb. if plugged for jam, pre-war prices). Scare birds off strawberries with dust shot. June 11th.Finished picking green gooseberries. Hoe raspberries by horse and hand. Cut lunners on young strawberries. Hoe nursery cuttings, etc. Brush hedges. Thin apples. Plum trees against walls will probably benefit by the application of dilute liquid manure, which helps to prevent the falling of young fruit. June 27.-Commencid to pick Morello cherries (stems cut with scissors at $3 d$. per peck pre-war). June 30th.-First raspberries ripe. Summer prune red currants and apple bushes.

JuLr.-Pick strawburries and cherries. Hoe pliantations. July 3rd, commenced to pick rasplocries ( $1 \mathrm{~d}$. and $\frac{3}{4} \mathrm{~d}$. per $\mathrm{lb}$. for first and lasit raspberries, 1 . per lb. for bulk, pre-war). Thin apples and pears where crowded, pick off any apples showing holes caused by Codlin Woth caterpillar or siawly maggot and lestroy to kill larræ: also pick off pears containing midge, and destroy them to prevent attack mext year. Iuly 9 th, commenced brushing strambelries with swol hook at $4 \mathrm{~s}$. 6 d. to 5 s. per acle, and raking off straw litter at 4s. per acre, pre-wal. July 11th, red curl'ants picked at $4 \mathrm{~d}$. pel peck: black currants, 5d. or 6d. per peck, pre-war. ('mmencel to gather Julian apples. Tie up straw litter and cart from strawberry fields, also cart helge brushings (useful for stack bottoms). Thin plums, remove superfluous glowth. Hoe plantations, cuttings, ete. : also commence picking Pershore and other plums green for cooking and jam making. Mulch with dung litter apple and pir trees bearing good erops. Take out deacl rood from cher'y trees and summer prune after clop is off. Pick walnuts gueen for pickling which used to sell at about 5s. per bushel, priwar. Pick loganberries and ripe gooseberries.

AUGust.-The plum month. Pick raspbelries, red and black currants and early apples. August 2nd, commenced picking ripe Rivers' Early Prolific plums (followed by Black Diamond, Orleans, Prince of Viales and Victoria). Brush hedges. Cart 
and stack strawberry litter. Brush strawberries. Hoe strawberries. August 8th, ripe gooseberries. Pot strawberry runners for glasshouse cultivation. Bud apple stocks. Brake and hand hoe strawberries; dig strawberry runner's, price, pre-war, 1s. $6 \mathrm{~d}$. per 1,000 or $9 \mathrm{~d}$. to dig, $9 \mathrm{~d}$. to trim and tie up in bundles. Horse hoe raspberries. If weather hot, water apple and pear trees bearing heavy crops to make fruit swell out. August 15th, commenced to gather carliest pears; pears should be picked somewhat before they are ripe, as many varieties decay in the centre if allowed to mature on the trees. August 25th, commenced to pick damsons. Pick filbert and cob nuts, cost $1 \frac{1}{2} \mathrm{~d}$. to $3 \frac{1}{2} \mathrm{~d}$. per peck of 7 lbs. in husk, pre-war.

September.-Gather plums, damsons, apples and pears as they mature; do not gather apples before they are ready or they shrivel if kept. Pull weeds from among raspberries. Horse and hand hoe all plantations. Hoe and dig strawberries, digging cost 25s. per acre, pre-war. Brush hedges. Plant wallflowers. Plant strawberries. Cut out old canes in raspberry and loganberries, burn the loganberry canes, but those of the raspberry keep as fuel for pickers next year. Tie up to the wires the young canes of loganberry. Gather pears and apples at intervals, avoiding gathering too soon or leaving too long; gather carefully and sort out imperfect fruit before storing. Sort most apples for market into three sizes; pick up fallen fruit but pack it separately from gathered fruit and send it off at once.

OCTOBER.-Dig strawberry runners and plant; fill up blanks among those planted in the spring. Early in the month put grease bands on standard and half-standard fruit trees. Pick apples and pearsmost of them are now fit to gather-gathering first those varieties that are beginning to fall or that part freely from the tree on the fruit being raised. Horse hoe and hand hoe strawberries and raspberries. Dig strawberry plantations, which cost 20 s. to 25s. per acre, pre-war, or earth up with ridging plough after hoeing out. Hoe gooseberry and currant plantations; sucker gooseberries. October 18th, commenced pruning gooseberries and currants, picking up cuttings. Take cuttings of gooseberries and currants, prepare to plant same in rows about 15 inches apart and 6 inches apart in the row. Brush hedges for second time in year. House all empty baskets not in use. Young plum and cherry trees and bush fruits may be planted at end of the month. Preparing cuttings of gooseberries and currants is an indoor work for early mornings and wet weather.

November. - Horse and hand hoe strawberries and raspberries. Dig up raspberry plants (cost 1s. 3d. to 1s. 6d. per 1,000, prewar). Apple and pear trees can be sprayed with lime-sulphur wash, as soon as leaves have fallen. Prune gooseberries, red and black currants, and plant any cuttings. Prune apples, pears, plums and cherries, clear and cart prunings. Get up straw berry runners and plant or bed in for spring use. Dig all plantations. Plant raspberries, according to land and variety about $1 \frac{1}{2}$ to 2 feet apart in the row; rows about $4 \frac{1}{2}$ feet apart. Subsoil land for fruit planting (the plough being followed in each furrow by a heavy horse hoe). Open land, digging with spade, 9 inches deep, cost $2 d$. per rod, or 25s. to 30s. per acre, pre-war. Digging up old grass land, cost $£ 5$ per acre; bastard trenching or digging two spades deep, cost 1s. to 1s. 6d. per rod, or £8 to £12 per acre; all pre-war prices. All land to be planted with fruit should be very carefully cleaned of weeds, especially couch-grass and bind-weed (small convolvulus) before planting. Fruit plantation digging with fork used to cost 20s. per acre; digging with spade costing about 3s. per acre more than with fork. Gooseberry bushes may be cottoned to protect the buds from bullfinches, chaffinches and house sparrows. Make good, wire work of loganberries. Sort and pack apples in boxes during rainy weather.

DeCEMBER.-Dung bush fruit plantations every second or third year. Fill and spread 30 tons per acre dung on raspberry plantations, with use of trolley and horse, cost 11s. per acre pre-war. Pruning mature black currants, $8 \mathrm{~s}$. to $15 \mathrm{~s}$. per acre, prewar' pruning mature red currants, 18s. to 25s. per' acre and more; pruning mature gooseberries, 20s. to 25s. per acre; collecting and clearing cuttings cost $4 \mathrm{~s}$, to 5s. per acre extra, pre-war. Lime-wash young apple trees: scrape bark and limewash trunks of old apple trees. Grub up 
plum suckers with mattock, ditto round nut bushes, break out wands from centre of nut bushes and prune fine wood. Send Blenheim Orange apples to market a fortnight before Christmas. Cart and wheel dung in frosty weather. Most pears will have been marketed before Christmas. Inspect apples, taking out any bad ones. Make boxes and pack best dessert apples in them. Grub up woodland, cost pre-war $£ 8$ to $£ 12$ per acre, it makes good land for growing fruit, especially strawberries. Ulain any water-logged land. Make up accounts carefully for Income Tax return.

Addition.r. Notes.-In April and May, if ipple trusses ar' attacked by sucker (Psylla) or plum is attacked by aphis, spray with nicotine and soft soap.

RABBITS ANI HARES. - A large and careful fruit farmer told me he had found the following mixture useful for kepping rabbits and hares aw wy from young trees, put on stems with a brush as soon as plantrd, and repeated the following autumn:-1 pint paraffin, 2 pints gar tar, 1! pints train oil, about 3 pints soot, thickined up to a thick paste with fresh cow dung. This mixture has long been used and nevel found to injure the trees, but it must be mixed with care and thoroughly. 


\section{CHAPTER II}

\section{SPRAYING AND SPRAYING MACHINERY.}

Br G. Fox Wruson, Spraying Expert to the Irupal Horticultural Society.

Much debate has taken place during recent years concerning the advantages of spraying.

Criticisms have been advanced on many sides, but too often they have been based upon an imperfect understanding of the aims and methods of efficient spraying.

To say that spraying is an absolute necessity in many cases is perfectly correct; for without this disagreeable, and often costly work, one cannot get the full yield of either fruit or flowers, while the outlay it involves is generally more than recouped by the increased value of the crops obtained.

inpraying is ton often unsuccessful, and a few of the reasons for ill-success will help to make clear where so many go wrong.

1. Ignorance of Pest.-This causes loss of time, labour and money.

2. Wrong Part of Plant Sprayed. - A knowledge of the disease and the part of the plant especially to be protected are needed for successful spraying.

3. Applying Spray at the Wrong Time.e. .. spraying with a caterpillar wash where the damage is actually due to a fungus attack, or applying a summer wash when trees are dormant.

4. Poor Pressure. - The liquid is made to leave the machine with little force. This means the penetration and wetting power are insufficient to do the work needed.

5. Nozzles.-Frequently the wrong kinds are used, producing too fine or too coarse a jet for the rarticular object aimed at.

These are probably the commonest mistakes in spraying.

There is one great difference to be bolne in mind in attempting to deal with insect posts as compared with fungi.
Tpraying against fungi is almost entircly preventive.

Frraying against insects is usually for the purpose of staying an attack already begun.

If insects are not actually present, it is usually waste of time, labour and money to spray.

If the invasion of a fungus is permitted, it will be likely to establish itself so firmly in so short a time that spraying will generally be too late to check its serious advance.

Knowledge is required by horticulturists as to the habits of the pests that attack plants.

Without this knowledge one cannot successfully combat them, e.g., insect pests may be divided into two great classes:-

\section{Insects that take their food by biting or chewing, and}

2. Insects that take their food by sucking the plant juices.

The former, the caterpillars, weevils, chafers, \&c., must be killed by poisoning their food, that is, by stomach poisons; the latter, aphis, psylla, scale, red spider, ic., must be killed by a contact wash, and it is in the latter case that penetration and wetting power of the spray fluid are specially needed, and these can only be obtained by the use of considerable pressure.

Stomach poisons should be made to remain on the leaves, when they are dry, preferably on the under surface, which is often hairy or woolly, and therefore holds the poison better than the shiny upper surface, and there it is less easily washed off by rain. Contact poisons must be put on so that "rery insect is hit, and therefore the under surface of the leares must be sprayed, as that is usually where the insects are. 
After heiry rain one often has to spray again, as rain 'asily washes off lead arsenate, \&c., but it also often does good as it distributes the flud to parts otherwise not r'iched by the sprayer, and this is noticeable in fungicides such as Bordeaux and Burgundy mixtures.

\section{Spraying Machines.}

General Precautions.-1. A sieve should be fitted on to the machine, through which all washes should be strained to prevent blocking of pump and nozzle, also the suction hose should have a fine mesh sierc fitted to doubly insure against any stoppage. sary, especially where insoluble substances like lead arsenate and the copper compounds in Bordeaux and Burgundy mixtures, which easily sink in the fluid. are being used. Without them one would often be spraying only a dilute wash after a few minutes' work.

3. Nozzles, which ar' one of the chief ficturs to be taken into consideration, will be dealt with later.

Different forms of spriying machines are used for different purposes and in varying circumstances.

Power Sprayers.-They are now coming into general use in lingland, boing move

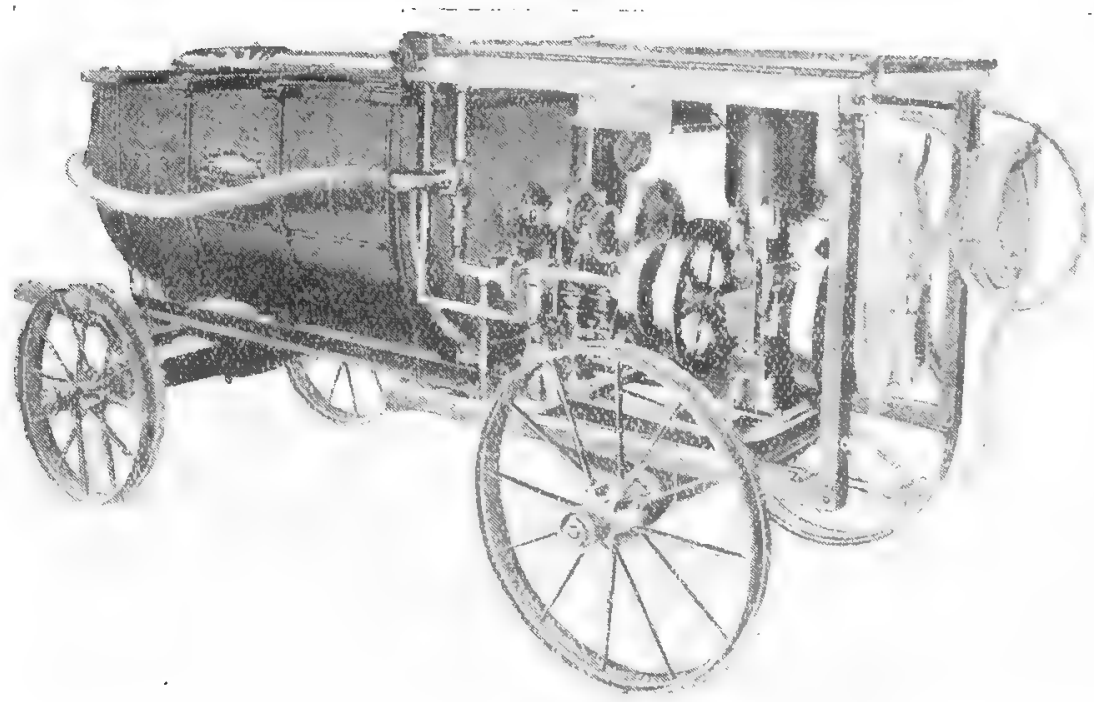

A Twholiors Motor Sprayn, of Ametem mabe; 200-gellous otpacity.

2. Wash out atter use before putting away with water or soap and water. the latter to be used attel oil emulsions. This cleansing applies to every class of machine, otherwise corrosion soon sets in.

The main points to be looked for in the purchase of spraying machinery are:-

1. An Efficient Pump, giving a good pressure and fitted with brass ball ralves and an air chamber, so that continuous pressure may be maintained.

2. Agitators.-These should work with the action of the pump, and are neces- efticient in pressure and do the work so mu'h quicker than hand-powel machines, and their use is meeting with great il)preciation.

It is considered to be economical to use motor sprit pump if there is more than 30 acres of truit trees. Such machines are largely used in large farms in our colonies, driven by oil or gas engines.

The spray find is mixed in a central tank and kept jroperly agitated: from this it is pumped through main delivery pipes laid permanently or temporarily in the planta- 
tions, with taps and connections at intervals for the connection hose pipes with 4 to 6 spraying jets.

\section{Horse- and Pony-Power Machines.-} These comprise a barrel or tank mounted on a 2 or 3 wheeled carriage, and used largely in spraying fields of potatoes or against Charlock. The pump is worked by a crank on the axle of the vehicle, and fairly good pressure and agitation are obtained, but a great fault lies in the distribution of the spray, which is so often directed down on top of the plants, this in the case of potato disease (Phytopthora), is useless, as the under surface of the leaves must be sprayed, for that is where the fungus finds an entrance.

An arrangement may be carried, however, for laying the haulm down before it is sprayed.

Barrel, Tank or Cistern Sprayers.These are popular machines for fruit farms and large gardens; they are quite efficient for spraying up to 20-30 acres, above which acreage power machines should be used.

The container holds 10-50 gallons; a useful size is 40 gallons capacity.

The eistern is best made of wood, as this will allow any wash to be used.

Caustic washes attack paint; copper sprays cannot be used in iron cisterns; lime-sulphur cannot be used in copper.

The one thing to be remembered in having a wood container is that it must be kept at least half-full of water when not in use, otherwise serious leakage is certain.

The wheels should be of a wide circumference, insuring easier traction, and the rims wide to prevent sinking into sandy or porous ground.

Agitators should always be insisted upon, and are usually attached to the pump piston, which gives constant agitation. One often hears that pulling the machine over rough ground agitates the liquid sufficiently, but this is quite incorrect. One man can only keep up sufficient pressure for one hose pipe; it is, therefore, better to have only one delivery hose than two. In using such a machine for potato spraying, one must see that the tank is not too near the ground, otherwise difficulty will be found in getting up the rows.
Pneumatic Sprayers.-These have come to the fore during the last few years, and are an excellent type of machines for average-sized gardens. They are made in hand and knapsack sizes, with capacities varying from 3 pints to 4 gallons; and can be obtained in an alloy resistant to all washes.

For several hours' or days' spraying they are much to be preferred to handworked knapsack sprayers, as pressure is not lost through the operator becoming tired.

One great disadvantage is that most of the machines have no agitator attached, and in others the agitators are of little use. The hand machines can, of course, be easily shaken, but one soon gets tired of shaking a 3 gallon machine on one's back! The principle is to pump the machine up to 90-120lbs. pressure per square inch (as indicated by a gauge), which will empty itself with but little reduction in pressure, and both hands are free to use a 6-10ft. lance for spraying tall trees.

The smaller machines are very useful for small greenhouses and gardens.

Hand-worked Knapsack Sprayers.These are often known as the Vermorel type of sprayer-a good, all-round machine for most gardens.

The disadvantage is that continuous pumping is necessary, otherwise there is no splay, and only one hand being free means that if a long lance is used considerable waste of spray may result. A capacity of $21-3$ gallons is the usual size, and one must have an iron container if Lime Sulphur is to be used, but these machines are also made in a similar alloy to the pneumatic sprayers and can be used for any wash.

See that an agitator is fixed either in conjunction with the pump-handle or by a stream of water being directed to the bottom of the container.

Bucket Pumps.-Bucket pumps are suitable only for small gardens and greenhouses, as such a machine holds from 2-5 gallons of wash, making it useless to spray large plantations because of its small capacity, the absence of efficient agitation, the recessity for continually lifting the machine to move it from place 
to Hace. A good pressure is obtained by thes' 1 umps, and agitation has to be done by stirring the wash with a stick.

Syringes.-In very small gardens a syringe is used suc'essfully for washing rose's and other plants of Aphides, but for any serious work it is quite useless because of the corirse nature of the spray, low pressure, and wastage of wash.

\section{Nozzles.}

These are one of the most important parts $t$ " insure successful spraying, and the choice of the wrong nozzle is a frequent cause of failure. It must be remembered that "Winter Washing" means what it says, and a jet of wash is necessary thoroughly to clear the bark of the tree so as to get rid of lichens that harbour insect life and disease spores, but be cone-shapud, and not flat across the top, oth"rwise too wide a spread of spray is obtained.

Lead Arsenate Nozzles. - This kind should be easily cleaned by a self-cleaning pin, which is pushed through a mediumsized ejector hole, when blocked by particles, such is the Vermorel nozzle.

Fungicide Nozzles.-These should give a spray resembling a ricotch mist, in order to get an even distribution of wash all over the plant, except in using Bordeaux or coarse washes, when one must use a

Bordeaux Nozzle.-An easily cleaned nozzle by turning stop-co'k right round to blow out any stoppare, and a fan-like spray obtained by turning the tap round.

Liming Nozzles.-For lime wash spraying a coarse jet which is self-cleaning is

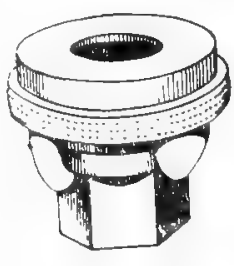

(1)

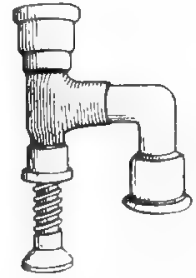

(2)

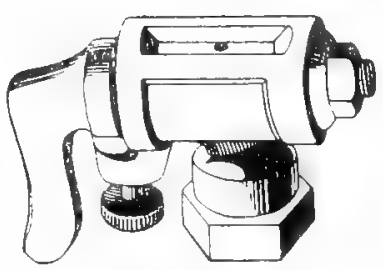

(3)

Types of Spray Hozzlos.

(1) A tjpe suitable for lime-sulphur. When used with large openings and high pressure it will not clog.

(2) A Epray nozzle fitted with disgorging needle

(3) A two-spray nozzle. One oide gives a broad, fine, fan-shaped gpray, and throw's as much or as little linuid as desired. and the other gives a long distance sprav.

spling and summer sprins need finer distribution, and may be applied in two or three ways.

Double and Triple Jets.-These are not economical in any way, and so much wash is wasted either through the nozzles being set wrongly and causing a crossing of the cones, or through too great an area being covered in the case of jets which issue at a wide angle.

A Medium-sized Cone fitted with self"l'aning pin is required for lead arsenate and other stomach poisons; a penetrating and concentrated jet for contact washes, and a fine, mist-like spray for applying fungicides.

Aphis Nozzles.-This class should give a penetrating spray, and the nozzle should required (it need not be adjustable); the make of nozzle best suited is one that is cleared simply by tapping the end of the nozzle against the trunk or a branch, when the ejector pin will clear the obstruction.

Angle Bends.-If the nozzles are not swivel-mounted, one must have an angle bend attachment to fit the nozzles on, for without this adjuster the under surface of leaves cannot be successfully sprayed.

\section{LANCES.}

These are indispensable in spraying tall trees of any kind, for without them the leaves and branches cannot be reached.

The usual method is to have bamboo poles of from 6-15ft. long, through which luns a brass tube. 
Angle bends can be fitted on the end to which nozzles should be attached, making the operation easy for spraying either the top or under surfaces of leaves.

\section{Powder Sprayers.}

These machines are intended for dusting plants such as potatoes, gooseberries, strawberries, vines, etc, with flowers of sulphur, etc., for mildew, or with hellebore powder for gooseberry caterpillars.

Horse-Power Machines.-In large plantations a horse- or pony-drawn sprayer is used, worked similarly to the other ponydrawn machines before mentioned, and the dust is spread in a fine powder on to the plants, usually when the dew is on the leaves to cause adhesion. Powder is found to enter the curled-up leaves where there is plum aphis, and kills the insects better than any spray, which cannot enter curled leaves.

Knapsack Powder Distributors.-These are similar in construction to the Vermorel knapsack pump, and hold 15-30lbs. of powder.

A short delivery hose fitted with a cone ejector cause the powder to be emitted in a fine dust, but, unfortunately, not very even]y.

Powder Syringe.-A good instrument for vineries or where only a little dusting is required. Much like an ordinary syringe, but fitted with a container of 1-3lbs. capacity near the ejector end of the syringe, and worked by pumping, which causes a flow of dust from a small hole.

I wish to acknowledge $\mathrm{Mr}$. F. J. Chittenden's great help in giving advice for the writing of this article. 


\title{
CHAPTER XXI.
}

\section{SPRAYING WITH LIME AND SULPHUR.}

\author{
Br Arthur Miskin, of Ladd's Court, Chart Sutton, Kent.
}

Having been asked to write my experience of the use of lime-sulphur as a spray wash for fruit trees, etc., I am only too pleased to do so, feeling quite convinced that the more it is used the higher the standard of British fruit will be raised, and in a measure it will prevent the foreign growel having the best of our markets to himself.

The use of lime-sulphur was first brought to my notice by a fruit grower from the Argentine, who was visiting me in the summer of 1909. He found a considerable amount of scab on my apples, and asked why I had it, and I told him that I could find no remedy except Bordeaux mixture, and that was uncertain and very liable to russet and crack the fruit, so that when we used it, it was with a certain amount of fear of doing more damage than good. He informed me that lime and sulphur could be used without this risk, and that it was the finest fungicide that he hat ever used; he added that the spray should be used as soon as possible after the leaf had fallen, and again in the spring just before the buds burst.

The following winter, 1909-10, I sprayed a considerable extent of my fruit once only, having some control pieces, and the following summer the results were so marked that I felt more than convinced that it was a remarkably fine spray to use, and since then I spray every tree I have (over 100 acres) with this compound, and I find that every tree so sprayed is cleaned of all lichen and moss growth, thus destroying the home for all kinds of insect pests. In addition, the foliage and fruits come much larger and better; in fact, in the case of plums, it is quite remarkable how much bigger the leaves are than on unsprayed trees. Again, the apples grown after this application are much freer from scab than I have ever seen them before; Allington Pippin and Worcester Pearmain, two sorts very liable to scab in my district, grew very clean last season. I am ready to discount the fact that the 1911 growth stands out as a particularly fine and free growth of apples, nevertheless I made exceptionally good prices of these varieties, as my salesmen can testify.

Then again, I firmly believe that brown rot may be eradicated by the use of this spray. However, it should be remembered I am giving my own experience, and the healthy appearance of all my trees has been continually commented upon by fruit growers who see them, and I am only too pleased to let anyone inspect them who chooses to ask me or will come and see me.

I do not call it an insecticide, except that it apparently destroys the eggs; it may be that it kills them, or it may be that it causes them to peel off the wood. I am not prepared to say which, but I will quote two cases. In the autumn of 1910 I sprayed all my trees with the exception of about half an acre of Rivers' plums in the corner of an orchard. Night came on too soon for us to finish that day, and I did not wish to start up the whole of my machinery for this small piece the next day, and so I thought I would leave it, and spray it when we were spraying again in the spring, which we accordingly did. The result was that in the summer the part of the orchard that was twice sprayed had no aphis at all, and much better and finer fruit than the half-acre only sprayed once, which had a lot of aphis, and which I had to spray three times for aphis, and then the fruit was not nearly so good and there was less of it. Another example:-My apple trees were so clean that it 
appeared superfluous to spray them again in the spring, so I only sprayed the sorts that were most liable to scab; the result was that where they were only sprayed once, I had a considerable attack of apple sucker, and that where they were sprayed twice they were practically free from this pest, so much so that I did not have to spray for this, but had to spray where rutumn spraying only had been done. These trees were mixed in various plantations, and were seen by many growers. All agreed that it must be the use of limesulphur solution, and, personally, I am of the same conviction.

I also find that it will at once kill gooseberry mildew, and that if it is used from time to time as the young wood grows, that this disease may be prevented.

I persuaded one hop grower to use it on a piece of very mouldy hops; he told me that it killed the mould straight away, and that it was the cleanest piece of hops that he grew last season. The variety was, I believe, Tolhurst's Goldings.

I could quote many more instances as to its beneficial qualities, and might mention that I use it on everything:-Nuts, gooseberries, currants, roses, as well as apples, plums, and pears.

I strongly advise the use of factoryboiled or steam-boiled stuff, and not that made in open coppers with a fire under them. There are many good makes on the market, and if experimented with, I am sure the result will be satisfactory.

I have often heard it said that machinery with copper in it must not under any conditions be used, for the spray will damage it. This may be so, but I have used the ordinary Vermorel Knapsack for the past three years, when spraying small trees, etc., and may say that these machines are as good as ever; thus the mischief is not great.

Concentrated lime sulphur is made to a specific gravity of 1.30. For winter strength 1 gallon is used to 15 gallons of water, for summer strength 1 gallon to 30 of water. In winter it has a cleansing effect; cleans off moss and lichen, prevents the spread of apple scab and other fungoid diseases, decreases aphis and apple sucker.

A coarse spray is used in winter, but a fine spray is used in summer.

Summer spraying with lime sulphur prevents the spread of apple scab, and brown rot on cherries and plums, but does not affect insects, as it is not poisonous. If the lime-sulphur is made on the farm, the formula is :-

$$
\begin{aligned}
& \text { Quicklime ................. } 6 \text { Ibs. } \\
& \text { Sulphur …............... } 3 \text { lbs. } \\
& \text { Salt ......................... } 3 \text { lbs. }
\end{aligned}
$$

Mix all together and add water to slake the lime, and then add more water and boil for nearly an hour; then make up to 10 gallons with water.

Factory made lime-sulphur is generally, however, considered better than homemade.

Cost of Spraying with Lime-Sulphur.

Some years ago Mr. W. E. Bear, of Hailsham, Sussex, gave me particulars of the cost of spraying $4_{1}^{1} \bar{v}$ acres of mature plums, giving them a thorough washing or, as he called it, a drenching. This was pre-war. Voss charged $45 \mathrm{~s}$. per barrel of 40 gallons, less 5 per cent. for cash and $5 \mathrm{~s}$. allowed for barrel when returned empty, plus carriage full $2 \mathrm{~s} .3 \mathrm{~d}$, and return of barrel 9d. Net cost of solution, 1s. $0 \frac{3}{4} \mathrm{~d}$. per gallon.

70 gallons used in 800 galls. water $£ 3122$

Manual labour .......................... $2 \quad 7 \quad 0$

$$
\text { Total cost on } 4_{\mathrm{T}^{\top} \mathrm{s}}^{\mathrm{acres}} \text {........ £5 } 19 \quad 2
$$

or $£ 19$ s. 1d. per acre, plus cost of horse carting water, which was not charged.

The dilution recommended for a strong winter wash was 1 to 12 . This was slightly exceeded.

The cost of summer wash of lime-sulphur diluted 1 to 40 and sprayed lightly, would probably not exceed 12s. per acre (prewar), as the wash would cost very little and the men's time would be reduced. 


\section{CHAPTER TXII.}

\section{CARE OF IMPLEMENTS.}

With the excuse of time taken to put away implements, carts, vans, and baskets, they are often left out in the sun and rain in summer, and some may even be left out for the whole winter in all weathers. On some farms there are not enough buildings to house all implements, but it is usually due to negligence that they are exposed to the elements which cause rust of iron work and decay of wood.

\section{Spraying Michinery.}

All apparatus should be washed out with clean water after use. For the knapsack sprayers, Mr. H. Chapelow finds it a good plan to fill the container with strong washing soda solution, and leave it for a week, this solution gets the oxides off the sides of the pump and pressure chamber, which material otherwise flakes off, and is constantly troublesome in blocking the nozzles when next used. In the Vermorel knapsacks two new rubber valves should be put in each year. Caustic soda or potash sprays which are not now used as much as formerly actually clean the machines well. Empty the reservoir of knapsack pumps, take pump to pieces, clean parts and oil working parts, and when finished with leave inverted. For the wheel or manual pumps, these should be washed out and parts cleaned and lubricated; the piston should be taken out of the pump and repacked with tow and Russian tallow. If the tank is wood (which is the best material as any solution can be used in it without harm), water should be kept in the tank to avoid the tank leaking when required. During hard frost if fear of freezing in the shed in which it is kept, it may be advisable to let out the water.

\section{Farm Implements and Carts}

now cost more to replace, so should be given extra care and protection from weather. They are subject to all sorts of hard wear, hot sunshine, wind and rain, which exposure causes decay and lust, decreasing their years of usefulness. As one insures one's house against fire, in like manner one should protect the farm implements against weather and the cost of replacing them. Mr. G. W. Jaap, in an article in "Better Fruit," for November, 1919, on "Adding to the life of Orchard Implements," gives some useful hints. Money spent on good paint applied to the implements during the season they are out of use is a good investment. I have myself witnessed a farm sale in which all the implements had been repainted, they sold at a far higher price than they would otherwise have done, in this case they were good implements but made to look their best. Every farmer knows that water will rot wood, and rust metal; that when decay sets in it does not take very long before the wood parts of his machinery are thoroughly rotted away, that when rust attacks the metal parts it is practically impossible to stop its action-it eats deeper and deeper into the metal until the part is so weakened as to be useless.

Paint is the best protection you can give farm implements. All decay begins at the surface and generally eats its way deeper. It follows, then, that by protecting the surface with a coat of good paint it is impossible for decay to attack the surface, and since it cannot reach the surface because of the protecting film of paint, it is impossible for the inner parts to rot or rust. The paint should be made with a lead or zine base, with pure linseed oil, which when properly applied offers genuine protection against wear and weather. The surface to be painted must be clean and free from grease or oil, and perfectly dry, or the paint will not adhere, and the best results cannot be obtained. 
Touch up the bare and worn spots with a thin coat of paint and allow to stand until perfectly dry, then apply a smooth even coat over the entire surface, using a good brush. The best implement paints dry with a rich oil gloss and give durability which at once increases the value of the implements, adds years of service to their lives, and stamps the farmer as being progressive and possessed of good business judgment.

$$
\text { Vans, Carts, Waggons }
$$

on which the colour finish is not worn, but which has lost its lustre, can be greatly improved, not only in appearance, but in actual wear and weather'-resisting qualities by a coat of carriage varnish, a clear finishing varnish, which gives a hard, tough, durable and elastic finish which is sunproof, windproof, waterproof and frost-proof.

Take an inventory of your farm implement. Set down the cost price and then figure the replacement value at present prices, and you will find it worth while to give them maximum protection against wear and tear and the action of the elements.
The best time to paint implements is in the fall, before they are put away for the winter months. They should be given another coat of paint in the spring, before they are put into actual use, for there is very little opportunity to apply paint to implements during the busy farming months.

Paint frequently and properly applied to farm implements is one of the best investments any farmer can make. Compared with the advantages of painting and the results obtained, you will find that the best paint you can buy for your implements is the cheapest form of protection you can obtain for your farm equipment.

\section{Hand Tools.}

It is advantageous in the way of durability and smoothness in handling to rub raw linseed oil on handles of spades, forks, hoes, rakes, etc., and to clean the soil off the tools before putting away. Vaseline is put on new iron tools to prevent rusting.

\section{Baskets AND BOAES}

should be kept under cover where dry and airy, and out of rain and sun. 


\section{CHAPTER XXIII.}

\section{SPRAYING APPLE PLANTATIONS WITH A LARGE PLANT. \\ By Lieut.-Col. Clive Murdoch, of Westerhill, Linton, near Maidstone.}

The plant referred to in the following estimate of th' cost of spraying consists of a Weeks' 3-throw pump working at a normal pressure of 1201 bs. per square inch, driven by a 3? -h.p. Blackstone portable oil engine. Both are mounted on the same foul'-wheeled trolley, to which is coupled a trailer carrying the 100-gallon suction tank. Water is taken from a 40,000-gallon concrete reservoir, situated nozzles of nearly golbs. per square inch, almost enough to do the spliaying without the use of pumps. The full working pressure on the pumps is only developed for the 20 to 30 acres at the top of the hill. Such advantageous conditions of working must add materially to the life of both engine and pumps.

Mixing of the wash is done in two 100-gallon galvanised tanks, alternately,

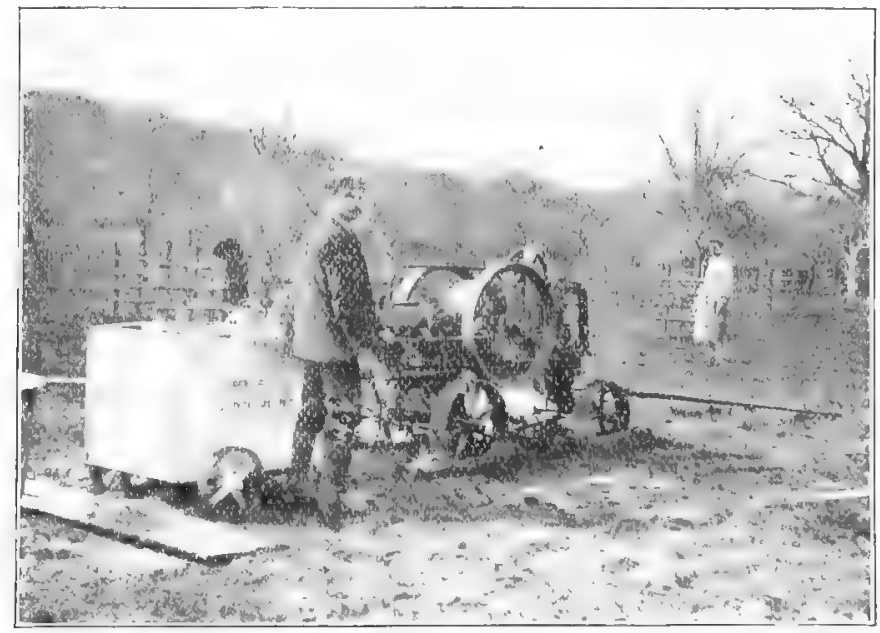

W. Weeks and Son's Thre-pump sprayer at work.

at the highest point on the farm. It receives its supply of rainwater from the adjacent buildings. The fact that the farm buildings happen to be on the topmost part of the farm materially reduces the working pressure, the area to be sprayed being on a hillside. The lowest plantation is 200 feet below the level of the reserroir, giving a static pressure at the one supplying the suction tank with wash while the other is being filled with water and the chemicals measured in. Two men can keep the plant going continuously, including looking after the engine.

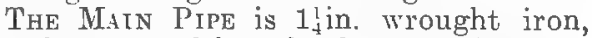
and has a total length of 900 yards, serving about 160 acres of fruit plantation. The use of tractor cultivation necessitates 
its being buried for a considerable portion of its length. At every 80 yards is a three-way valve, with connection for the branch piping. At each valve is a "running joint" so that the valve may be removed for repairs or storing in winter without moving the main pipe itself, which is never disturbed. The lowest point of the pipe has a tap for draining off after use-a necessary precaution against frost.

Portable Steel Piping 1in. in diameter, in 16-foot lengths, is used for the branches. Normally, the simplest and least costly lay-out would be to connect the rubber hose which supplies the nozzles directly to the main pipe, but the farm in question being irregular in plan, long lengths of main pipe would have to be laid nozzles will cover a piece of ground 80 yards by 40 yards at each setting, or two acres per setting for the six nozzles.

THE LABOUR REQUIRED to manipulate the plant is as follows:-

Running engine and mixing, two men; carrying and laying portable steel pipes, two men; carrying and hauling rubber hose, three men; at the nozzles, six men; total, thirteen men.

The Estimate of Cost Per Acre is based on an expenditure of 4,000 gallons of leadar'senate-nicotine wash per day of nine hours to spray 10 acres of half-standard apples, large trees 15 years old, 150 per acre, with an interplant of bush apples. The cost per acre obtained below must, therefore, be regarded as a maximum.

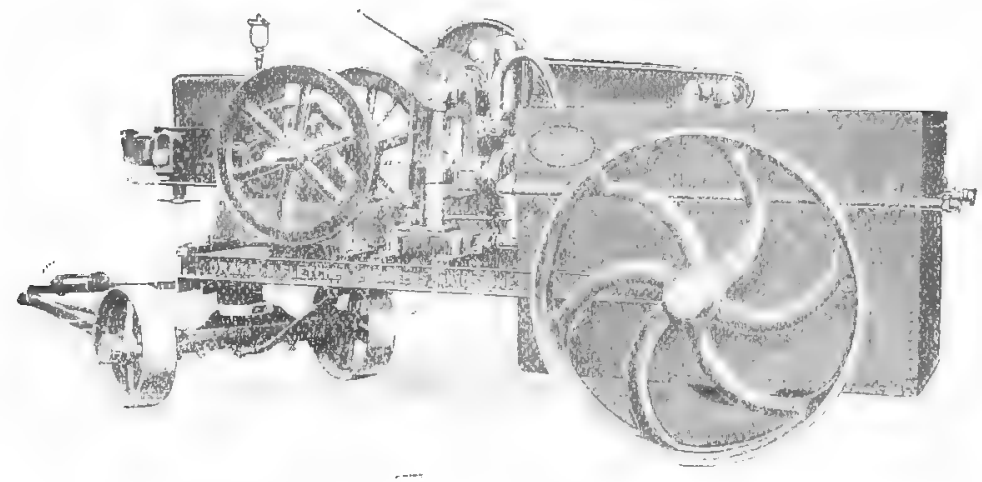

A "Drake and Fletcher" Power Spra ying Engine, Mark A.P.S. Completely Self-contained Engine, Pumps, Tank and Agitator.

down to serve only a few acres of plantation. Portable pipes were therefore adopted, 60 lengths being required to reach the farthest points from the main pipe. Each length has a short connecting piece of armoured rubber tube for flexibility, and when laying the pipe-line a 3-way tap and connection for the rubber hose is inserted every eighth joint (about 40 yards).

The Rubber Hose consists of three sets, T-shaped when laid out on the ground. The "leg" of each $\mathrm{T}$ is s. pipe, 4-ply thick, 40 yards long. The "arms" are two $\frac{1}{2}$ in. diameter pipes, each 20 yards long, and each carrying a nozzle. It will be seen that cach pair of
It will be observed that the cost of the wash itself is by far the largest item. Where unnecessary to use nicotine the cost per acre works out at about $£ 27$ s.

Chemicals. -6lbs. of lead-arsenate at 1s. 2d. per lb., 7s.; 60zs. of nicotine at 1s. 10d. per 0z., 11s.; total per 100 gallons, 18s.; 4,000 gallons per day at 18s. per 100 gallons, £36.

L.1Bol' 1. -Thirteen men at 9s. 1d. (this includes $6 \mathrm{~d}$. per day extra during spraying), £5 18s. per day.

Machinery and Pipes.-Depreciation, 10 per cent. on $£ 500, £ 50$; cartage of (nllgine and pipes, \&c., £2; total, £52. £52 spread over 16 working days, $£ 35$ s. per dily. 
Fitli, oIl ANd grease $4 \mathrm{~s}$. per day.

Supervision.-Proportion of foreman's time, 6s. per day.

INTERest on CaPitil. -6 per cent. on $£ 900$ equals $£ 54$ : spread over 16 working days, £3 7s.; total cost per day, £49.

Cost per acre, at 10 acres per day, $£ 4$ 12s.

\section{Fruit Spraying on a Smaller Scale with Motor Power.}

\section{BY C. H. HOOPER.}

In one plum plantation at Pershore the following outfit was at work this spring:
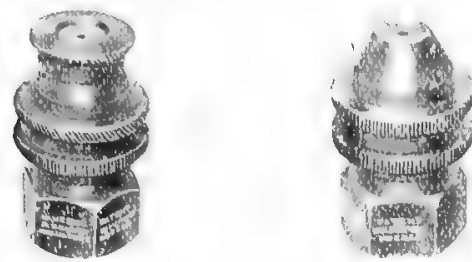

W. Meeks and Son's, Ltd., Outside Adjustment Nozzle.

A Weeks' (of Maidstone) spray pum fitted with Amanco engine of 3 to 4 horse-

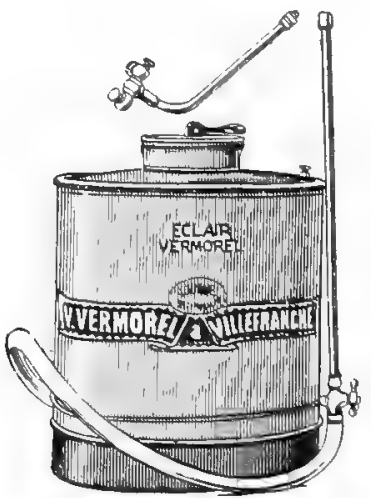

Vermored Knarsack Sprayer.

power, taking 2 men to look after engine and get limewash ready; 4 men with four lances. The acreage sprayed depends on the iron piping being laid to the best advantage. Other things being favourabl", this equipment could limespray about $2 \frac{1}{2}$ acres per day of mature plum trees (planted about 16! ft. apart for Pershore egg plums, 18ft. for Prolifics, 21ft. for Monarchs).

On Mr. E. P. Whiteley's fruit farm at Pershore a Drake and Fletcher 1 $1 \frac{1}{2}$-horsepower engine, drawn by a horse, with 4 lances, with 100 yards 1 in. steel piping, a three-way tap every 30 yards; 2 9oft. $\frac{3}{4}$ in. rubber hose laterals running at right angles to the steel piping, each having 2 $60 \mathrm{ft}$. rubber pipes terminated by a lance, making 4 lances in ail. By this disposal it was estimated 5 to 6 acres could be sprayed, using nicotine and soft soap or similar wash with the engine in one position.

A Maidstone grower told me that with 13 men employed, 6 nozzles in use on 20 . rear-old apple trees, 500 gallons of wash were used per acre and 8 acres sprayed in a day.

Limewise Spraying Fruit Trees.

Lime-spraying is so much believed in at Pershore that Mr. P. D. Poole, of Pershore, contracted to lime-spray orchards at $8 \mathrm{~d}$. to $9 \mathrm{~d}$. per tree'; my brother had 10 acres of mature plums and apples somewhat closely planted thus sprayed at a cost of $£ 100$. The aim is to get the lime on as hot as possible, as thick as possible (ideal, the thickness of eggshell) and as late as possible, eren to the opening of the flowers in the case of apples. Motor spray pumps put on the lime-wash at a pressure of about 90lbs. per square inch (in ordinary spraving $120 \mathrm{lbs}$. per square inch is preferred); if a very high pressure is used with lime-wash the wash is wasted. The bore of the nozzle used is nearly $\frac{1}{8}$ in. At the present time hand-picked Buxton lime, which is the best lime for the purpose, costs 62s. 3d. per ton at Pershore Station. An acre of fully-grown fruit trees requires nearly a ton an acre of lime to spray it thoronghly. After using lime all the machinery and pipes should be cleaned as much as possible, or little bits of lime stop up the nozzles at the next spraying. 
Spraying by Krapsack Pump.

Year's ago I once kept account of the eost of spraying an acre of bush apple trees 11 years old, planted 9ft. apart (too close), using a Vermorel knapsack. It took 107 gallons of water (43 knapsacks of $2 \frac{1}{2}$ gallons); 10 ozs. of Paris green at $2 \mathrm{~s}$. per lb., 1s. 3d.; 9lbs. of copper sulphate at $3 \frac{3}{4} \mathrm{~d}$. per $1 \mathrm{~b}$., $3 \mathrm{~s}$. ; 12lbs. of lime at ${ }_{4}^{1} \mathrm{~d}$. per lb., 3d.; labour (one man $2 \frac{3}{4}$ days at 4d. per hour), 9s.; cartage of water and use of pump, water, say, 1s. 6d, ; total 16s.; 16s. divided by 494 trees equals nearly $\frac{1}{2} \mathrm{~d}$. per tree.

Since then the fashion of sprays has changed to lead arsenate and lime sulphur at a higher cost. The present cost would be three or four times as muchsay $£ 3$ per acre, or $1 \frac{1}{2} d$. per tree.

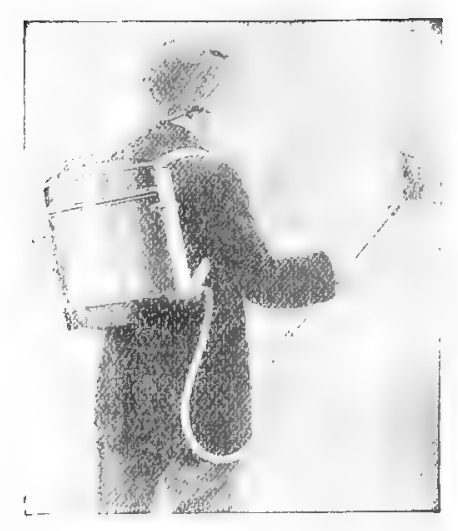

Four Oaks Knapsack Sprayer at work. 


\title{
CHAPTER XXIV.
}

\section{THE NATURE AND USES OF MANURES.}

\author{
By W. S. Gray, B.Sc., A.I.C., late Lecturer on Chemistry at Wye Agricultural College.
}

The problem of how to increase the cropproducing power of soils is one of vital importance at the present time. An average soil contains all the constituents a plant requires for its growth, but a sufficient quantity may not be present in an available condition to enable one to obtain the high yields now demanded.

The system of manuring by means of stock is the mainstay of farming; fruit growers, and especially market-gardeners, rely much on farmyard manure. The reason is not far to seek, for dung contains everything the land wants to enable it to grow large crops, except, perhaps, phosphates. This being so, it is worth while taking care of it in storage, as it has been proved that fully 50 per cent. of the value of dung is lost by exposure to rain.

Horse manure is of a dry nature. It ferments rapidly and is liable to "fire-fang" unless well stored.

Stable manure, purchased from towns, may be of poor quality nwing to the inclusion of street sweepings and the loss of the urine. Cow manure, on the other hand, is cold and watery. In each case, however, the value depends largely on how the dung has been stored, and it has been shown that a layer of earth on the top of a heap is one of the best safeguards against loss.

Numerous experiments at Rothamsted and elsewhere have proved that to obtain the largest crop yield it is better to employ a moderate dressing of dung, plus artificials, than to put on a very heavy dressing of dung alone. By this procedure the soil is improved in texture by the organic matter of the dung, and the artificials enable a crop to be given what it particularly requires. Turnips need phosphates ; potatoes and fruit respond readily to potash. The war has shown us that we can supply this constituent to a large extent by saving wood ashes, which contain about 10 per cent. of potash.
Nitrogenous artiflcials are of two kinds, "readily available" and "slowly available." The former type includes nitrate of soda, sulphate of ammonia, nitrolim, nitrate of lime and nitrate of ammonia. The "slowly available " comprise shoddy, dried blood, horn, hair, woollen and leather waste.

Nitrate of soda is in a form ready for the plants' immediate use, but is easily washed out of the soil. Sulphate of ammonia is slower in action but is "held" by the soil.

Nitrolim is also slower in action, and should not be applied with seeds, as it arrests germination for about ten days, after which the effect disappears.

Nitrate of ammonia, a comparatively new fertiliser, contains 35 per cent. nitrogen, as compared with $15 \frac{1}{2}$ per cent. in nitrate of soda, bence the relative cost for carriage per unit of nitrogen is much less; and, further, it has no detrimental effect if applied to stiff soils.

Shoddy supplies nitrogen more slowly than the above manures, but gives a good return; and where a steady application of nitrogen is required over a more extended period, as in the case of hops, it is especially valuable.

Dried blnod is excellent, but the unit value on the market is much too high as a rule to justify its use.

Horn and hair wastes, although containing a high percentage of nitrogen, are slow in action.

The Phosphatic Manures form another group of fertilisers, and the most important are Superphosphate and Basic Slag. The former is obtained by treating rock phosphate with sulphuric acid, and so producing a readily soluble phosphate which is quick in action. Basic Slag is a by-product in steel manufacture, and, although slower in action than super, costs less per unit, and is to be preferred on stiff land. Bone meal, in addition to containing about 45 per cent. phosphate, supplies 3 or 4 per cent. nitrogen, but 
the market price is often such that a better return will he obtained by expenditure on other phosphatic and nitrogenous manures.

Fish Guanos also supply both nitrogen and phosphates, and are very valuable for all forms of intensive culture, but, here, again, the unit price may be so high that the mineral manures give the best return for money.

Potash is essential for potatoes, fruit and leguminous crops, but our supply is likely to be below requirements until export from Alsace is increased. In the meantime much may be done by utilising wood ashes, as stated above. and by the application of lime, which liberates the potash reserves in the soil. Blast furnace flue dust, containing some 5-7 per cent. potash, has given satisfactory results, and may be employed. Most market gardeners, however, will probably return to the use of sulphate of potash or kainit as soon as these are obtainable, the former containing 48 per cent. potash, and the kainit rather over 12 per cent.

The relative values of different fertilisers can easily be compared by means of the unit system of valuation. The unit adopted is 1 per cent. of a ton, that is, $\frac{1}{10} \overline{0}$ of $2,240 \mathrm{lb}$. or $2241 \mathrm{~b}$.
The Fertilisers and Feeding stuffs Act provides that a seller must state on his invoics the actual percentages of Nitrogen, Phosphate and Potash contained in the manure.

The unit price of an ingredient is found by dividing the price per ton by the percentage present of that ingredient. An example will make the method clear :-

Sulphate of Ammonia contains 20 per cent. of Nitrogen and is sold at $£ 1710$ s. per ton, that is, one ton contains 20 units of Nitrogen, hence the cost per unit is $\frac{£ 1710 \mathrm{~s} .}{20}=17 \mathrm{~s} 6 \mathrm{~d}$.

The value of a compound manure may be obtained in the same way :-

INVOICE. Price
per Unit. $\quad$ s. $\mathrm{d}$. Nitrngen............. 4\% 17s, 6d. $=3100$ Soluble Phosphates $15 \%$ 4s. 3d. $=3 \quad 3 \quad 9$ Insoluble Phosphates $5 \%$ 1s, 6d. $=076$ Potash................ 4\% 8s. 0d. $=1120$ Value per ton $=£ 8133$

The cheapest manure to suit one's purpose can thus be readily ascertained from the market prices and a few simple calculations, and thus a substantial saving made on the yeur's fertiliser bill. 


\section{CHAPTER IXY.}

\section{SOILS IN RELATION TO PLANT FOOD AND PLANT GROWTH.}

(The following is brsed on a pamphlet: "Agriculture in New Zealand," published by the Educational Department of the New Zealand Expeditionary Force).

The fertility of a soil depends upon its ability to supply plants with c. itain conditions and substances essential to growth: these include: (1) Water: (2) Air; (3) Temperature; (4) Food; (5) Adequate root room: (6) Absence of injurious substances and of harmful soil inhabitants (such as denitrifying bacteria, fungi, harmful protozoa and larvæ of insects).

The Food of Plints.-Plants require certain elements, each of the first ten in the following list are required in rarying proportions, any deficiency below requirements reduces growth. All the mineral substances are absorbed from the soil through the roots in dilute solution:-

Plant food is often the limiting factor in soils, and the elements usually not naturally sufficiently available to produce large crops are phosphorus, nitrogen, potash and lime. Food supply can be increased by adding fertilisers, ploughing in crops-preferably legumes-and feeding crops and foods to animals on the land.

SorLs are formed by the weathering of rocks and by the addition of regetable

EIEMENTS UF PIANT FOOD.

Elejent.

(A)-Carbon.

(B)-Hydrogen.

(C)-OXYGEN.

Absorbed as
Fixction or Effect on Plaxt.
(D)-Nitrogen.

(E)-Pноsproros. . ... Phosphates from soil.

(F)-Potassium. ... |

(G)-STLPHUR.

(H)-Magnesidur. ... ... Magnesium salts from soil.

(I)-Calciorr. $\quad \ldots \quad \ldots$ (Cilcium or lime compounds

(.J) - IRon. Iron salts frum soil.

| Carbon dioxide from air... ... | Starch, sugars, oils, and protein pro(Carbonates from soil. ... ...

C Carrier of Plant Food.

Maintains turgidity.

Formation of Starch.

Sugars, Oils, and Proteins.

Promotes growth of herbage and leaf growth in trees.

Delays maturity.

Essential for Proteins.

Promotes root growth.

Hastens maturity.

Seed and Fruit production.

Occurs in Proteins.

(Starch and sugar production.

Potilsh salts from soil. ... ... ( $\begin{aligned} & \text { Starch and } \\ & \text { Disease resistance. }\end{aligned}$

Fruit production.

Occurs in Protein.

Too large a quantity, requires to be nentralized by lime until proportion is two of lime to one of magnesium

Required essentially by legumes; also for the seeds of fruits, and for cauli. flowers and cabbages.

i Necessary for the formation of green colouring matter of leaves.

(K)-Sudicy and ChLorine are beneficial to plants having their origin near the seashore, e.g., mantrels, beets, and asparayus. 
and animal matter. The nature of the soil depends on the rocks from which it was formed, and the manner in which it was formed.

The amount of humus or decayed vegetable matter largely influences the character of the soil; it affects the water-holding capacity, the texture and the supply of nitrates.

Soils are classified as under :-

SANDY aNd GRaVeliy SoILs are usually early, but dry out quickly in the summer. They are often deficient in humus, this can be supplied by ploughing in a green crop, preferably a leguminous one. Lime is often needed.

LOAMs form our best agricultural and fruit growing soils. Loams with a fair percentage of sand are good potato soils. Heavier loams containing a fair amount of clay or silt are suited to most crops.

('L.IYs are the heaviest type of soil, are usually hard to work, and the work has to be done when in right condition. They produce good crops when well cultivated and improved by drainage, liming, subsoiling and manuring.

Calcareous Solls, formed from limestone or chalk formations. Usually splendid soils for rearing young animals on. Often deficient in vegetable matter and water supply.

Peaty SoILs.-Soils containing a large amount of vegetable matter. Require liming and draining. Cranberries are grown on these soils in Canada. 


\section{CHAPTER XXVI.}

\section{THE MANURING OF FRUIT TREES AND BUSHES.}

By Bernard Drer, M.Sc., F.I.(n., anthor uf "Fertilizers and Feeding stuffs, their Properties and Uses.' and for 20 years Consulting Chemist to the Manure Trials on Fruit and Vegetables at Hadlow, near Tonbridge, Kent.

The manuring of fruit crops is a much more difficult question than the manuring of vegetables, for it does not follow that a manurial treatment which best feeds the plant and stimulates its general growth necessarily encourages the production of the greatest quantity of fruit. It is common observation that a tree or plant in what appear's to be poor condition may sometimes be loaded with fruit, while another, in much more flourishing vegetative condition, bears less satisfactorily. Everyone knows that our rield of fruit is enormously affected by seasonal and climatic conditions, and these conditions affect very much the results of manuring. An application of manure that may in one season appear to be injuriously large, may in another season prove to be ever insufficient. A timely fall of rain or a few days of sunshine at a critical period is of more consequence than all the care that can be given to manuring. We cannot, howerer, command the weather, and our study should be to ensure that the plant has at its disposal whatever may be necessary to enable it to take full advantage of favourable weather should this be forthcoming.

The suggestions now to be made are those gathered from experiments carried on over many years hy Mr. F. IT. E. Shrivell, F.L.S., and miself at Hadlow. Though we have not by any means reached finality in our conclusions, I gladly give such views as we hare arlived at.

\section{STR.W BERRIES.}

It is almost impossible to forecast the result of manuring strawbervies. So much depends upon the incidence of rain and sunshine in determining whether the manuring tells in the production of fruit or merely in the fostering of leaf growth and the production of "runners." "We hare taken something like 20 crops of strawberries of various varieties, manured under varying conditions. Sometimes heary dunging has produced better results than light dunging, but more often light dunging has been better and more. economical. In many seasons a light dressing (12 tons per acre) of stable manure was all that was necessary to enable the plant to produce a full crop. In other rears the addition of chemical fertilisers to the stable manure has proved profitable as regards total yield. The earliness of the crop, however, is sometimes influenced by fertilisers more than the total yield, and this is of great importance, seeing that, during the early days of strawberry picking, the price per pound is often at least double that obtained for the later gatherings. The general conclusion at which we have arrived is that for stranberries a light annual dressing of stable manure (not more than 12 or 13 tons per acre) should be used in preference to a heavier dressing: 4 to 6 cwt. of superphosphate per acre being given at the time that the dung is dug in. This treatment should be followed by a dressing of 2 cwt. of nitrate of soda per acre, sown between the rows during the spring. If stable manure is used no potash salts need be added.

\section{Gooseberries.}

The most economical treatment is a moderate annual dressing of stable manure (say about 12 tons, or 25 small cartloads, per acre), with about 6 cwt. of superphosphate and $1 \mathrm{cwt}$. of sulphate of potash per acre. These latter should be well dug into the ground with the dung 
at the end of winter. Four cwt. of nitrate of soda per acre should be given, divided into two dressings, in the early spring.

A liberal supply of potash is, in our experience, essential to the growth of a first-rate crop of gooseberries, even with a good dressing of stable manure.

\section{Currants.}

These may be treated similarly to gooseberies.

\section{RAspberries.}

Taking one year with another, we have found that a moderate dressing of stable manure has done as well by itself as when supplemented by chemical fertilisers. In some years the addition of chemical fertilisers has increased the crop, but in other years the yield of fruit was less than without them. Heavy dunging, with as much as 25 tons per acre, has produced on the arerage a smaller crop than light dunging. Our experience, however, has been confined to the soil of one particular field.

It may be added that we have also tried the growth of raspberries without any stable manure at all, and under these conditions the fertilisers already mentioned for gooseberries will produce good results if stable manure cannot be spared.

\section{Plums.}

With the exception of one year, the trees have borne well during the last five years. The results of manuring in different ways have been very variable, but as far as they warrant a conclusion it would be that, taking one year with another, the most economical way of manuring well-established plum trees would be to dispense with the use of stable manure, and to give an annual dressing of superphosphate or basic slag-say $4 \mathrm{cwt}$. per acre of superphosphate, or 6 cwt. per acre of basic slag -with, say, 4 cwt. per acre nitrate of soda, the nitrate being divided into two dressings.

\section{APPLES.}

Apple orchards should be kept clear of grass. This is not the usual custom, but recent investigations have proved very clearly that the well-being of young apple and pear trees is seriously hampered by the growth of grass, apparently owing to the excretion from the grass roots of some substance which, though minute in quantity, injuriously affects the roots of the trees. If bush fruit be grown between the trees and manured as already directed (see paragraph relating to gooseberries), the fertilisers being fairly distributed over the whole of the orchard, the apples will get their share of the treatment, and will be grateful for it both in development and in fruit production. Heavy applications of stable manure, such as 25 tons per acre, have proved disadvantageous as regards vield of fruit. A moderate dressing of stable manure, with phosphates, potash salts and 4 cwt. of nitrate of soda per acre, applied as just suggested, will exercise a good influence on the trees.

\section{General Observations.}

In the foregoing notes it is assumed that the soil is an average loamy soil of fairly heavy consistency. On very light or freely draining land it would be desirable, where 4 cwt. of nitrate of soda per acre is recommended, to substitute, for the first 2 cwt. of nitrate, 4 cwt. of high-grade Perurian guano, or 5 cwt. of fish guano, or 8 cwt. of rape meal. This should be dug in with the phosphatic manure and potash salts, 2 cwt. per acre of nitrate of soda being then given as a top dressing. But where the soil is of fairly strong to medium consistency, 4 cwt, of nitrate of soda per acre, divided into two dressings, may be looked to for producing the same effect.

On land that is poor in lime it is well, instead of using superphosphate every jear as a source of phosphates, to use superphosphates one year and a liberal application of basic slag or phosphatic Peluvian guano the next year, and to continue this alternation.

\section{Manures Recommended by Fruit Farmers.}

Mr. Charles Martin, when at Toddington, found phosphatic guano, superphosphate, or other phosphatic manure good for both bush and top fruit.

Sir Walter Berry, of Faversham, applies one ton wool waste, and half ton bone meal per acre before planting gooseberies and fruit trecs.

For strawberry growing near Southampton peat moss manure is applied before planting. 


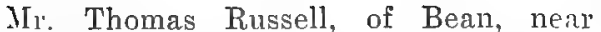
Gravesend, used to use four or five cwts. fish meal per acre for his fruit plantations.

The Duke of Bcilford and Mr. Spencer Pickering, F.R.S., found fish guano for gooseberries, black currants and raspberrirs better than the manurial equivalent in superphosphate, sulphate of potash, sulphate of magnesia mixed together and nitrate of soda applied separately. Mr. George Hammond, of Pilgrim's dew.
Hatch, Brentford, Essex, likes to put about eight cwts. hoof, horn and bone meal on his fruit plantations in March, or early in April.

Mr. James Allen, of Stanhill, Wilmington, used to apply fish salt as a manure for raspberries, the fish scale, bone and roe supplying nitrogen and phosphate of lime, whilst the salt increased the moisture in the soil, absorbing it from the 


\section{CHAPTER XXVII.}

\section{PRUNING AND PRUNING INSTRUMENTS.}

Pruning is of great importance in fruit production; the pruner is to some extent the steersman to the energy of the plants.

This chapter deals chiefly with general principles.

STRAWBERRIES should have their runners periodically and frequently cut off to strengthen the parent plant, unless young plants are wanted for propagation.

RAsPBERRIES.- The pruning of this fruit consists in cutting out all canes that have borne, which may be done duxing winter, or, best of all, immediately or shortly after the finish of the fruit picking, also in winter thinning the new canes, and in spring topping the canes.

GooseberRIEs.-The Kentish (and pro= bably the best) method of pruning gooseberries is to cut out the older branches, thereby encouraging the younger ones, keeping the bush sufficiently open to allow the entrance of the hand from all directions. Very little tipping or spur pruning is done. In Worcestershire the tips of the boughs are pruned. Where American Mildew exists the Ministry of Agriculture requires that all young shoots should be tipped, as it is this part of the bush that is chiefly subject to mildew. Suckers should be stubbed out with an instrument like a sharpened crowbar.

Red Currants are usually grown on a "leg," branching into five main branches, some of which may be allowed to fork once. These branches are annually spurpruned and the leader shortened. The bushes may also with advantage be summer pruned, which is good for the fruit, as it exposes it to the sun and also lessens aphis attack.

Black Currants. - In Kent their growth is kept young and not too tall by yearly cutting out from the centre of the bush some of the oldest branches, as the younger wood is found to produce cur- rants more plentifully and larger. In the case of black currants the branches should spring from the ground-i.e., the bush should not be on a leg. In making cuttings all the buds are left in, and the young bushes are for two years icut back hard to make them sturdy.

Plums and Cherries (whether standard, half-standard or bush) should be gradually trained to good shape in the nursery, and are not afterwards heavily pruned, as taking large boughs out of cherries and plums is apt to start gumming. Dead wood should, however, be cut out and the general shape looked to yearly. The fine wood of Morello cherries should be lightly thinned yearly.

DAmsons can be rejuvenated and brought back to fruit production by heading back the branches within a few feet of the trunk, say, once every ten years, as if left untouched these trees grow very tall, almost cease to bear fruit, costing much to pick the fruit; there is also the risk of the gatherer falling, as the branches are brittle.

(Note. - Insure your fruit pickers. A small holder at Chilham employed a man to gather cherries. The second day he was shot in the eye by the son, scaring birds. Ever since, now severlal years, the small holder has had to pay so much a week to the man, the total amount yearly being almost equal to the rent of the holding.)

Standard Apple and Pear trees should be carefully shaped in the nursery; and, when older, crossing boughs should be cut out and the trees gencrally kept somewhat open to admit light and air. If the standard trees are of moderate size the branches may to some extent be spurpruned, and the terminal leader shortened. By this means fruit can be borne almost from the trunk to the extremity of 
the bough. One needs, however, to know or study the habit of the variety of apple as to where it forms its flower buds to avoid cutting them off, as close spur pruning is not suited to all varieties.

Bush Apple and Pear trees thrive well when moderately spur-pruned and the leaders shortened, whereby beautifullyshaped trees are obtained which bear fruit in perfection if the other necessary conditions suit the trees, remenabering, however, that trees of different variety, like with human beings, have individual characters, which need to be studied in order to obtain the best results; thus some varieties of apple produce their fruit buds at the extremity of the twigs, so that if these are cut off the possibility of fruit is gone.

Now for a few ideals to aim at in pruning:-

Every cut should be made with a reason, and points such as pruning to an outward pointing bud should be kept in mind; each tree should be pruned annually, so that it may be seldom necessary to remove large limbs.

Although pruning may be done through- out the winter, probably the best time is in autumn, just after the leaves have begun to fall. Light pruning may be done at any time during the summer (end of June or July).

Trees making very little wood need manuring or better cultivation.

If a limb has to be cut off, saw it off close to the trunk or main branches, so that the wound may heal readily, as if a stub is left, decay is apt to set in, due to fungus or insect attack. The object of an orchard may well be borne in mind: to produce the largest quantity of best quality fruit at least cost, human labour being reasonably paid.

Sunshine has a wonderful influence on the formation of fruit buds, as well as on the colour of the fruit. Trees cr branches in shade will not fruit as well as those that are in sunlight.

Pruning needs common-sense, care and patience. Proper pruning means economy of spraying materials.

A good example of pruning instruments as used by Mr. Wolfram Dannreuther, F.R.H.S., on his fruit farm at Battle, Sussex, is given below.

\section{Pruning and Planting Implements.}

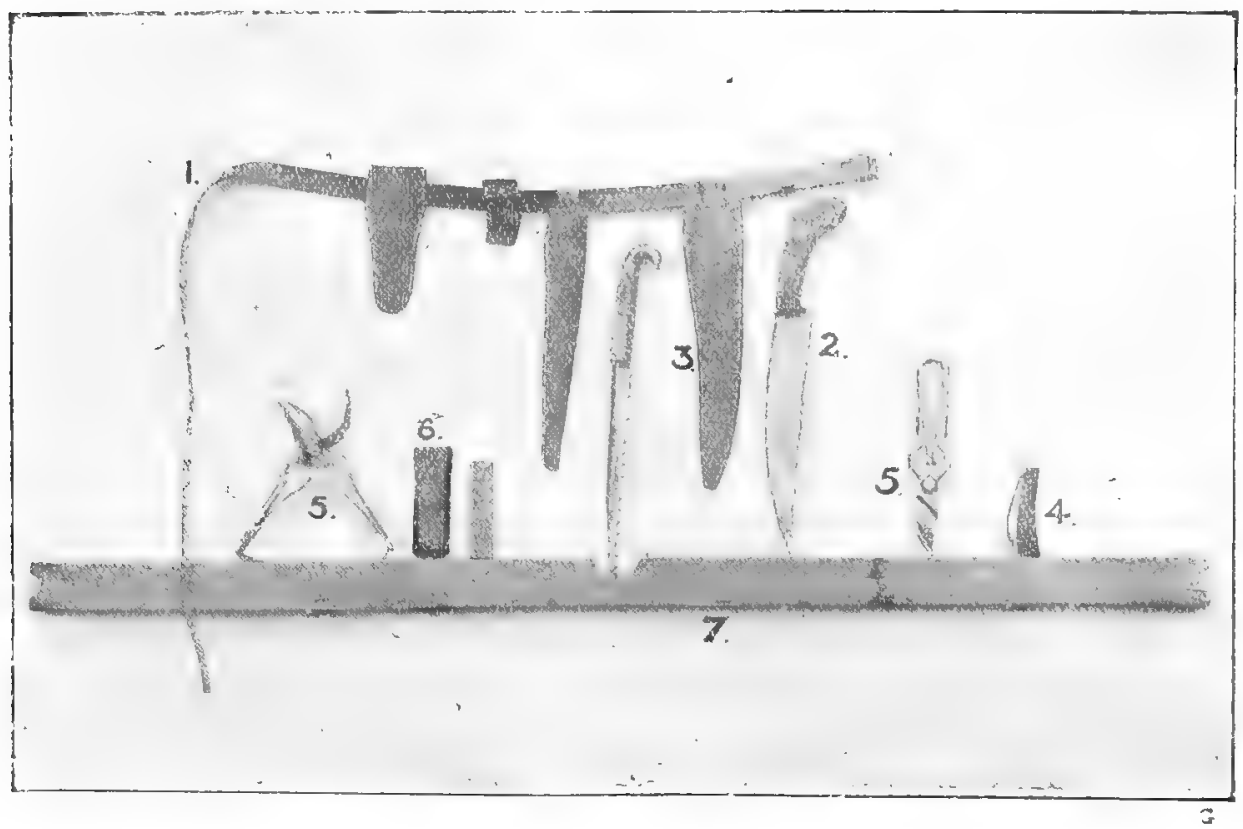


1. Leather belt, 3ft. 6in. to $4 \mathrm{ft}$. long, 1in wide, long enough to cover an overcoat, with leather sheaths to slide on, to hold saws and secateur.

2. Curved saw with small fine teeth,

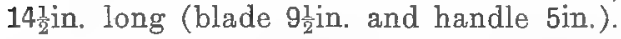

3. Saw, with large teeth, curved handle, 13 $\frac{1}{2}$ in. long (blade $8 \frac{1}{2}$ in. and handle 5 in.), will cut through a bough $4 \mathrm{in}$. in diameter with great ease.

Both saws, which cut on a downward pull, are of French manufacture. Saws resembling No. 2 can be bought in England, but they are much larger and not so well fitted for the work.

4. Knife to pare saw cuts and bad cuts made by secateurs.

5. "Westminster" Secateur. The springs are very good, and there is a catch to prevent the bolt slipping. These secateurs used to be sold by the Army and Navy Stores for 3s. 6d.

6. Sharpening hone and case, the sportsman's combination stone, manufactured by the Carborundum Co., Niagara Falls, N.Y, 4in. long, $\frac{1}{4}$ in. thick, in leather case, is a splendid stone for sharpening secateurs and knife.
7. Planting board 4 to 5ft. long. The places where the trees are to stand having been marked out with small sticks, the centre of the board is placed against the stick where the tree is to stand, and two additional sticks are placed one at each end where the board is cut. The board is then taken away and the hole dug. Then the board is put back between the two sticks and the stem of the tree is placed at the central notch; after a little earth has been placed in the hole the board can be removed, and the tree will be in the exact spot required.

I feel this short chapter does not do justice to the important subject of pruning, but for a more complete and thorough treatise on the subject I would recommend an excellent and illustrated little handbook on "Pruning" written by Mr. Hammond, of Pilgrim's Hatch, Middlesex, a practical fruit farmer, and published by the Lockwood Press, 1, Mitre Court, Fleet Street, London, E.C., price 1s. Also the leaflet on "Pruning," sent free of cost on application to the Ministry of Agriculture.

To learn pruning the beginner needs to work with a good pruner who is willing to explain the reason of his practice. 


\section{CHAPTER XXVIII.}

\section{FRUIT TREES AND THE SOIL.}

By A. R. Horwood, F.L.S.

It is an extraordinary thing that, in spite of the available knowledge existing as to the relation of fruit trees to the soil, little or no advantage is taken of the stores of knowledge on this very essential point awaiting the experimenter. At the same time it must be admitted that field practice has to a very large extent followed intuitively, or as a result of accumulated practical cxperience, the main lines of scientific knowledge in regard to soil and the adaptation of particular fruittree types to a particular soil or group of soils. It is satisfactory to know that this is the case, but at the same time, in order to give the fruit-grower seeking information an idea of what to do in making a choice of a farm, what districts to select from, a brief summary may be helpful.

It is of great advantage to know what class of habitat and soil the wild tyres of our cultivated fruit trees require. It is only within very recent years that this knowledge has become possible by means of systematic vegetation surveys, which have by no means yet been completed for the whole of the British Isles. Consequently a good deal of information on this matter is unpublished, and so unavailable to everybody-only to the few investigating the question, of which the writer is one. Of the score of cultivated fruit-trees generally grown, half of them or closely allied, wild types are found in the British Isles.

It is not possible yet to indicate how far the numerous cultivated forms of each species, some noted for fruit, some for early ripening, and other cultural properties, differ amongst each other as regards soil. It is the main species in the general sense that we can alone deal with at present.

Wild Cherry (Prunus (Yerasus) is found naturally on sandy soils in oak birch heath, and in sandy oak woods, as opposed to those of clay and loamy soils. It also grows well on chalk in chalk scrub. The allied Gean (Prunus tvium), on the contrary, may be found on clay and loam in damp oak woods, as well as in beech woods on chalk, and no finer examples can be seen than those growing on the top of Box Hill, in Surrey, which, though large trees, yield abundant fruit. It also grows on siliceous soils, or close, greasy, sandy or gritty soils, derived from slate rocks in sandy oak woods.

As a general rule cherries require mixed soils, sandy and gravelly loam. Allied to the cherry is the Wild Sloe, and closely connected with this is the Bullace, both of which are allied to the Plum. The Sloe is found on clays and loams in damp oak woods and on sandy soil as well, also in oak'birch heath, and on limestone and chalk. The Bullace grows well on chalk scrub. Generally, clay and marl soils suit the Plum. The so-called Wild Plum to-day is usually the cultivated form run wild.

The Crab is a frequent tree on clay and loam, in damp oak woods. It also grows on sandy soils in oak birch heath, on the close and sandy or siliceous soils. Crab also grows well on the chalk. The general soil for Apples is a loam or a marl.

The Wild Strawberry grows on clay and loam, on siliceous soils, limestone, chalk, and marly soils. In a wild state it requires shade.

All the species of Ribes, Gooseberry, Red and Black Currants, grow on black or amorphous peat, overlaid by silty allurium in fen formations.

The Raspberry grows on sandy soil, in the oak birch heath, and also on limestone. Hazel grows on clay and loams in 
damp or dry oak woods, forming coppices, also on limestone and chalk. Remains of it are found in peat beds. It grows at a higher altitude than any other tree producing domestic fruits or nuts. The Blackberry, and with it one may associate Loganberry, a hybrid, grows on dry and stony soils, sandy soils. A similar soil suits the Vine.

The Hop grows on alluvial soils, overlying peat (amorphous), in the marsh formation.

Wild Pear is very uncommon in this country. It will grow on most soils, and higher up than the Crab. It thrives better on light sandy soils than clay. This is in strong contrast to the Crab, which grows mainly on stiff soils inclined to be clayey, which makes better cider, a good loanay soil, and apples trees grown on light sandy soils produce cider which has a tendency to become acid after a time.

There is some connection between soils and altitude, for at the higher altitudes the rocks are older and harder, and often exposed at the surface, forming hills by their greater hardness, valleys being formed by various agencies in the softer rocks. Valleys and plains, as a whole, yield deeper soils, varying in texture and porosity. The upper limit of the oak and other deciduous trees is not much above the limit of cultivation of wheat, or 1,000 ft. Birch and pine grow at 1,200ft. and over. IIost trees grow at altitudes of 400 $500 \mathrm{ft}$., and at altitudes of 700-800ft. and more it is unprofitable to grow them. The same applies to fruit trees, which do not do well above 500ft.

In general trees, in which we may include fruit-trees, do best on rich loam, which may be to some extent gravelly, or even peaty. The depth of soil most suited to habit and growth is 2-3ft., on a good, not hard or barren, subsoil. The differences between the requirements of each plant are, however, important, not only chemically, but physically. Trees must, in any case, have good drainage, and soils liable to accumulate stagnant water are highly inimical to fruit-trees. The closeness or openness of a soil again determines the root-extension, and as root-systems of different fruit-trees differ largely, they must have a soil exactly suited to their requirements in this respect, some deeprooting trees sending down roots to a depth of 7-8ft., whilst large trees extend theirs as much as 100ft. horizontally. The shallow soil is not $1 \mathrm{ft}$. deep, medium soils, 1-2ft., deep soils, 2-4ft. Deep soils are mainly clays and loams. Slope has some effect in addition in relation to soil characters. A slope of 30 degrees is a suitable one. On such sheltered soils the mulberry will grow on well-drained sandy soil.

It is of importance to know the characters of soils from a chemical as well as a physical standpoint. As regards chemical properties the principal question is the proportion of lime salts, and of organic matter or humus. Roughly, soils may be classed as clay, loam, sand, limestone or chalk, humus or peat, saline. The proportion of lime salts, humus, saline matter, has a chemical effect; and sand, clay and loam are terms relating rather to physical properties determining such factors as texture, porosity, capillarity, water-bearing capacity and circulation. Apart from the organic matter, the elements or substances in all rocks of an inorganic nature are silica, alumina, calcic carbonate, phosphoric acid, sulphuric acid, potash, soda, ferric oxide, magnesia chlorine, combined in various forms, and it is from these that the plant obtains its nutrient salts in soluble form by action of the roothairs on the soil particles.

Some soils contain more of one substance than other. Silica is more abundant in sands and clays; 80 per cent. in the former and $60-70$ per cent. in the latter, whilst limestones contain only 20-30 per cent. In clays the silica, in the form of aluminates, is more available than in sands. In clays the alumina causes the stiffness of the soil, there being 6-10 per cent., and only 1-4 per cent. in sands, which are thus much less adhesive. Lime salts may be present, in the proportion in chalk of 90 per cent.; 60 per cent. in limestones; and in marl of 25 per cent. In clay and loam there is from 1-3 per cent.

The other constituents occur in small quantities, and have often to be supplied, especially phosphates and potash salts, artificially. In clays there may be 1 per cent. phosphoric acid. Potash occurs up 
to 1-2 per cent, and in aluminous soils or clays more abundantly.

These constituents can only be determined, so far as actual proportions go, by chemical analysis, and the terms already employed-sand, clay, loam (a mixture of clay and sand), lime humus-afford the main criteria as to composition, either chemically or physically. There may be sandy loam or clayey loam also. Light soils are sandy, heavy soils clayey, as a rule, and wet soils are clayey or peaty; dry soils sandy or limey or calcareous.

The physical properties depend on texture, porosity, absorptive power to retain water, heat retaining properties or temperature. As regards texture the particles vary in size, from gravel or stones, sand or grit, to clay. A mixture of clay and sand with humus makes a properly porous or ventilated soil. Sandy soils are loose, porous, easy to work and warm; clayey soils heavy, retain water, and are too close and cold.

Light and heavy soils are also distirguished as degrees of tenacity. Sandy soil is lighter than clay, which is heavy, stiff, and difficult to work. Lime soils are close, but do not retain water so much as clays. Peat soils are light and porous.

The retentive power of soils depends on their texture. Clay soils are retentive, and collect the soluble and insoluble matter in rain water, ammonia, etc., and absorb it. Whereas sandy soils do not do this. Sandy soils absorb water more freely than clays, but do not retain it. Lime soils are intermediate.

A dry soil is warmer than a wet soil, hence sand is dryer than clay, and lime soils are also warmer than clays. Welldrained land is $3 \mathrm{deg}$. F. warmer than undrained land. Hence fruit-trees grow better on warm than cold soils, as they require good drainage.

Now all these properties of the different types of soil are important in considering the different requirements of particular fruit-trees. And such types are derived from the various subsoils, which in turn are the weathered surfaces of the natural rocks or geological formations, of which there are some 40 or 50 different kinds in the British Isles.

It is advisable to give examples of some of these in order to indicate the regions where suitable soils may be expected to occur. The outcrops of the rock may be ascertained by referring to a geological map of the British Isles.

Clayey soils, with 95 per cent. clay, are formed from the Kimmeridge Clay, Gault, and London Olay, and a clay which contains a fair amount of gravel and stones occurs in the Boulder Clay, which overlies the solid or older rocks over a great part of England, north of the Thames Valley, formed during the ice age. A less dense clay, or loamy clay, with 25 per cent. clay, is formed also by the London clay. Marly soil (20 per cent. lime salts), occurs on the chalk, chalk marl, Keuper marl. Loamy soils (70 per cent. clay), are derived from the Bracklesham Beds, Middle Lias, and brickearths in valleys. Loam of a gravelly nature is also found where the boulder clay is of this nature, as in central and East England. Sandy loam (40 per cent. clay), is formed from the Bagshot Beds, Upper Greensand, Old Red Sandstone. Silt is a fine earthy or muddy kind of sand, and found where there is alluvium in river valleys, or as warp in estuaries. Silty loam is another product of alluvium; sandy or siliceous soils are derived from blown sand, of the sea coast, etc., Bagshot sand, Lower Greensand. Sandy soil, which is siliceous and calcareous, is provided by blown sand, Middle Lias, midford sand; brashy soil is formed by Cornbrash, and other Oolitic rocks. Earthy ferruginous soils are found on Carboniferous Limestones, as a residue, and sandy and loamy ferruginous soils are also afforded by the Middle Lias ironstone, Corallian, Keuper, and Bunter sandstones. Peaty soils are formed by present day peat on mountains, moorland, bogs and marshes; gravelly, pebbly soils are derived from valley and plateau gravels, Blackheath beds, Bunter pebbles.

To turn, now, to where some of these formations are developed, and where fruit-trees grow best upon them. It is to be noted that such formations differ as regards texture in different districts, and other considerations, such as proximity to sea, altitude, rainfall, temperature, make one district better than another, and in studying suitable conditions, meteorological conditions must be taken into account, as well as the soil. 
Apples are best grown on loamy soils, fairly deep, preferably on slopes to get good drainage, and flourish on old red sandstone, permian and triassic sandstones and marls, lias, calcareous sandy loams of the middle lias; on lower lias in Somerset, and generally in Devon, Somerset, Dorset, Gloucester, Hereford, Worcester, around Edinburgh, and in some parts of Ireland. The Pear grows well on a variety of soils, but rich, deep, soils, similar to those on which the Apple grows, as well as on the chalk.

The Cherry grows on rich, loamy, rather deep soils, lower eocene, brickearths in the valleys in Kent, and on loamy soils overlying chalk also. Light loam, or gravel of the valley drifts and lower eocene in Kent, and loamy, chalky soils in Surrey and Sussex suit the Cherry.
Clayey or gravelly soils, derived from lower lias and valley gravels in the Avon district and Vale of Evesham, in Worcestershire, Gloucestershire, etc., suit the Plum.

The valley gravels and brickearths on Oxford clay in Huntingdonshire, on gault and drift in Cambridge, old red sandstone in Brecon, etc., are suited to the growth of small fruits of the orchard type.

Calcareous loam, deep and rich, in sunny situations on sloping hillsides in Kent, on Thanet and Woolwich beds, on loamy, clayey soils of Sandgate, Hythe, and Atherfield clay in Surrey and Sussex, also loam on weald clay, in Surrey and in Berks. and Hants., are best for growing hops.

Such a brief survey gives the main points to be noted in choosing sites for orchards. 


\title{
('HAPTER XXIX.
}

\section{BIRDS IN THE ORCHARD.*}

\author{
By Frederic Smith, of Loddington, near Maidstone, Kent.
}

The House Sparrow.

Few farmers have a good word for the house sparrow. He pokes his nose into everything but a trap, of which he is very shy. He eats the buds of gooseberries, currints, plums, etc, and as soon as thi blossoms of cherries appear, he gives them a peck to extract the little drop of honey they contain, effectually destrying the embryo fruit. The blossoms of plums, damsons, gooseberries, black and red currants, the flowers in the garden, and sometimes those of apples and pears all share the same fate. I have not room rnough in this paper to describe his bad deeds, but I think one of his wor'st teitures is his fondness for the lady-birds and their larva, the niggers. I have watched the sparrows repeatedly going systematically to work over hop vines and fruit trees. I have seen them begin at the bottom leaves of a pole of hops and follow the winding of the vine to the top, taking off every nigger from under the leaves and then beginning at the bottom of the next pole. I think the sparrows are responsible for the decrease in number of the martins: they allow the martins to nearly complete their nest and then take possession of it. If the nest was quite finished the sparrow could not get in, so he quietly looks on till he sees it will suit him, and then promptly takes possession.

The Blackrird and Thrush.

Blackbirds have increased enormously of late years. Before gun licenses came into force they were kept down very much by people going round the roads and

*This paper was read before the Maidstone Farmers' Club, and, being of special excellence as to observation, is reprinted here with Mrr. Frederic Smith's kind permission. shooting them in winter. Large numbers were killed in this way, but I think no one wishes to see every village lad running about with a gun, to the danger of himself and the public. Of late years we have had very mild winters, and that has allowed them to increase very much; also a much larger acreage of land is strictly preserved for game now, and that allows the birds to breed in safety. The blackbird begins to eat fruit as soon as it colours, and spares no variety, beginning with early strawberries and going on to gooseberries, currants, raspberries, cherries, plums, damsons, apples, pears, and figs. The damage they do is very considerable, as they spoil as much as they eat, or even more. I have for the last seven or eight years trapped over 1,000 blackbirds and thrushes yearly. This year, from the quantity left to breed, I shall have to destroy at least 2,000 to keep them at all within bounds-that is on about 200 acres of fruit. Thrushes, I think, are almost as bad as blackbirds. They do not eat figs, and are not so troublesome with the apples, but all other fruit they are as partial to as the blackbird. The thrush is partially migratory, going south as the weather gets winterly. If the North and Midlands have much snow they come to our county, and seeing plenty of fruit trees they stay on and add to our already over-crowded bird population.

\section{The Bulleinch.}

The bullfinch is the most destructive bird the fruitgrower has to contend against. They rove about in families of five or six through the winter. A family will come into a fruit tree and stay there till they have destroyed all the budsboth bloom and leaf buds. They usually begin with Mayduke cherries in the early 
autumn and keep on with plums, gooseberries, currants and medlars, ending in the late spring with black currants and apples. For six months they live almost entirely on fruit buds, the other six months on seeds of various wild plants. I find some fruit-growers still think they do no mischief. My men have shot 285 bullfinches this winter, in the fruit plantations. Ornithologists living in or near towns often think birds do not take fruit buds. The reason is that near large towns the buds become so saturated with soot that they are distasteful to birds.

\section{The Starling.}

I do not think the starling has altered his food. The great increase in their numbers makes it more noticeable when they attack corn (which they have done at times for many years back). They are so numerous now that the mischief they do is very marked. Cherries and damsons are the fruits they attack most. I believe the mild winters are responsible for the great increase in their numbers. They do a great amount of good as well as mischief, but the number should be kept within bounds. Some years back I watched a pair of starlings feeding their young. It was a warm, damp day, and one of the old birds kept appearing with two or three grubs. The young ones were just getting a few feathers, and were old enough to put their heads out of the opening to be fed. I wondered how the old birds knew which one to feed, so I went to the nest, which was in a box with a lid (placed for the purpose) in an outbuilding. Opening the lid, I was able to observe the process. Each bird, when he had receivsd his food, went to the back of the nest, and came round in rotation to the front. One bird a little larger than the others, and evidently a bully, pushed the others aside and came forward out of turn. The old bird, returning with two fat grubs and a worm, was going to push them down his throat, when she discovered his little game. She threw her head back, swallowed the food herself, and stepping into the nest took the young bird by the wing, gave him a violent shaking so that he fairly screamed, and then pushed him right to the back of the nest.

\section{Blue Tit and Cole Tit.}

I am sorry to see the indictment against the blue tit; he is such a jolly little bird and so audacious. He does some mischief in the autumn by pecking apples and pears, but all the rest of the year he is looking for small insects and their eggs, and at present I shall not sign his death warrant. The cole tit is much more mischievous, he destroys the buds of black currants in the spring when they are opening. He throws off the leaves by a right and left jerk of the head, and eats the embryo bunch of currants. I have always found him worse than the blue tit at the apples and pears. For several years now I have saved my fruit in the garden from their depredations by planting sun-flowers. If there is enough sunflower seed they will not touch fruit. The tits frequently peck the bunches of pear and apple blossom buds just before they open and in all cases I have examined they contained the larvæ of some insect.

\section{Great Tit oR Ox Eye.}

The great tit occasionally takes a few plum buds in early spring, but I think the balance for good is in favour of the tits, and although they have very large families, they do not seem to grow more plentiful. I have known the great tit bring out 15 young.

\section{BLACK CAP.}

A family of black caps in a cherry orchard commit great havoc. They do not eat a quarter of the fruit they pick. They are also very fond of raspberries, and, as for figs, they will consume enormous quantities. The fig acts on them like Glauber salts, and they keep eating all day. It is the worst summer bird we have in the fruit plantations, and I think the only one of our summer visitors that does much mischief.

\section{JAY.}

In the neighbourhood of game preserves the jay sometimes does much damage to the apple crops by taking a bite out of any rosy-faced apple that looks tempting, spoiling very many, without consuming any great quantity. $\mathrm{He}$ is also a great nut-cracker, taking the point of the nut off as you would with a knife, inserting his beak, and opening the nut. $\mathrm{He}$ is 
very fond of green peas, and plums do not come amiss to him. Where fruit is grown he should be kept down.

\section{Chaffinch.}

The chaffinch is not generally considered a bad bird, but he is a great disbudder of fruit, gooseberries, currants, and plums, especially after a frost, when these birds will be found in twos and threes all over the plantation, eating the buds. They are responsible for much of the damage done to plums, cherries, gooseberries, and currants, by squeezing the blossom to extract the honey in it; while they are also very fond of lady-birds and their larvæ, clearing off large quantities of these useful insects. They are partially migratory, coming from the north in large quantities in the end of October or beginning of November. This winter has been so mild that they have not come south.

\section{Green LINNET.}

I do not know that I ought to include the green linnet. He does not eat fruit, although he takes a few buds and pinches some blooms. But he is a terror in the hop-gardens when the hop-seed is ripening, pulling the hops to pieces to get the seed and doing so much damage that he ought to be kept down to some extent in this country.

\section{The BARN OWL.}

I must say a word for our friend the owl. I am sorry to see he will soon be a rare bird unless something can be done to save him. There is a general idea among keepers that the owl is a destroyer of game, but I do not think he deserves that character; he lives chiefly on mice, rats, beetles, and moles. I once gave a tame owl eleven mice; the last one certainly stuck out of his mouth for some time but by jumping vigorously, with his head pointing straight upward, the bird succeeded in getting it down! The owl is very inquisitive, and that sometimes leads to his destruction. I was once waiting on an ash plantation to get a shot at a rabbit in the dark, when an owl came round me several times; finally, it settled a few feet in front of me, and, after bowing in its grotesque way several times, flew straight at my face, settled on the top of my head, remained there a few seconds, and then swooped round a few times and passed on his way. If preservers of game would have the owl protected they would be doing a good service to the country generally. Unfortunately, the owl has a money value to preservers of skins for screens, etc.

\section{The Kestrel and The SparrowhawK.}

The kestrel should be reckoned with the owl as one of our best friends, living on young rats, mice, black beetles, grasshoppers and some small birds. Like the owl, he will soon be exterminated if something is not done to preserve him from the gamekeeper. The sparrowhawk is too fond of game and poultry to be protected.

\section{Damage BY BiRds.}

The amount of fruit consumed and spoilt by birds is enormous. A few years back I left an estimated quantity of 300 tons of damsons. In about three weeks they were all cleared off by the blackbirds, thrushes, missel birds and starlings. I do not say they ate 300 tons, because the fruit shrivelled, and, besides, the stones would represent a large item; but then other growers left very large quantities, and they were eaten in the same way. I think many birds have a keen sense of smell, and come from long distances to where food is to be had. A few years back I sowed a field with tares. There had been no green linnets seen on the farm for weeks, but then they began to arrive in little parties of five to nine, and before dark the field was swarming with them. They must have smelt the seed.

I think much harm is done by the birds destroying ladybirds and their larvæ, the lacewing $\mathrm{fly}$, the ichneumon fly, etc. In bicycling in Normandy, Brittany and Touraine I was much struck by the absence of birds. There were no thrushes, blackbirds, sparrows, etc. In a circle of 500 miles through the country I did not see any crop damaged by insect pests, except the small ermine moth in the apple trees, and birds will not eat this in any case. There were plenty of buzzards, harriers, the smaller hawks, and the little owls. Magpies were the most numerous. It is just the sime in 
Belgium. When I inquired there if they had no birds, the answer was that they had eaten them all. But the crops were certainly not suffering from insect pests, and I cannot but think we very much overrate the good the birds do and do not take into consideration the harm they do in destroying the predatory insects. There are, of course, many birds that do no harm, and these should be protected as much as possible.

For reducing the number of sparrows the best thing I have known was Harding's prepared wheat. It would not kill anything larger than a sparrow or mouse -it would not kill rats or poultry. But the Government of the day brought in a
Bill making it illegal to poison wheat in any way. Still, something might be done by appointing a certain number of men to kill the sparrows through Kent by this means, by permission of the Board of Agriculture.

Sparrow clubs account for great numbers. Our Broughton Club reported one year 5,933 birds brought in, but that makes no perceptible difference in the number. In the good old times the churchwarden paid head money for sparrows, and that kept them more within bounds. Sparrows should be destroyed generally, and blackbirds, thrushes, bullfinches, chaffinches, green linnets locally where they are too plentiful. 


\title{
CHAPTER XXX.
}

\section{WILD BIRDS IN RELATION TO FRUIT GROWING.}

\author{
By Walter E. Collinge, D.Sc., F.L.S., F.E.S., M.B.O.U., \\ Lecturer on Comparative Embryology and Zoology in St. Andrew's University.
}

The relationship existing between wild birds and fruit growing is by no means the simple matter that some people would lead us to suppose; indeed, the longer we study the question the more difficult and intricate does it appear. Nevertheless we now have considerable data, obtained from investigations extending over fifteen years, which enables us to fix with greater precision than previously the economic position of a large number of species, that is to say, we now know the percentages of the different kinds of food that each species consumes and the ratios these bear to one another.

Tbis information has been obtained by examining the stomach and intestinal contents of large numbers of birds from all parts of the country, and during each month of the year, and whilst the results obtained may not hold good for a particular district, they do show us the nature of the food as a whole and the particular quantities of each item that a bird feeds upon.

If such an investigation were made upon the birds obtained in one district only, it is very possible that the results would show variations from those here given, due to the local conditions as regards food supply, and the scarcity or abundance of the species concerned.

It will, we think, be obvious that such a method of estimating the food of any species of wild bird has great advantages over all others, for it is exact and at once shows the average significance of the food, further, it takes cognizance of all the food consumed, and we are thus enabled to state definitely the economic status of a species, which is not possible by any other method.

Observations made in the field or orchard, whilst very useful, are seldom exact enough. Every investigator knows of instances where birds have been shot "devouring fruit" or "eating garden peas," and when the stomach contents have been examined not a particle of vegetable matter has been found. It therefore behoves us to deal very warily with such observations, made, no doubt, in the best of faith, but nevertheless faulty.

In endeavouring to fix the economic position of any species of wild bird, it is of the utmost importance that we should place on one side prejudice, hearsay, and preconceived ideas, and rely only upon scientific facts and sound judgement.

Take the case of the Thrushes, both species are condemned by practically all fruit growers. It is perfectly true that they do destroy a certain amount of fruit, in some cases greater than in others, but if the fruit grower destroys these birds and so thinks that he will have a larger crop of fruit, I am certain that he will be disappointed, for the number of injurious insects that these birds destroy more than compensates for the amount of fruit destroyed. Unless thrushes were very much more numerous than at present it would be a very short-sighted policy to destroy them.

In the case of the Starling we have very different conditions. This species is far too numerous. There must be hundreds of starlings for every thrush in the country, in consequence of which they do an enormous amount of harm.

The Bullfinch stands in rather a different category. It is not over-abundant, but from January to the end of May it is wholly destructive, and as its food for the remainder of the year is of a neutral nature, it commits great harm with practically no compensating advantages.

What we want the fruit grower to reqlise is that a bird must not be condemned as injurious to fruit growing simply because at 
a certain season of the year it injures or destroys fruit buds or fruit. What we must try and find out is the result of the sum total of its activities from year-end to year-end, so far as it is related to the fruit grower. This is the only fair method and the only one that should guide us.

\section{Misplaced Prejudices.}

Let us revert to the case of the Song Thrush. Fruit growers are loud in their condemnation of this species. An examination of its food throughout the year shows that from October to April it feeds upon injurious insects, slugs, snails, earthworms and the seeds of weeds, during May and again later, it is busy rearing its young, and similar food, excepting the vegetable matter, is brought to the nest. We have now June to September, a period of about four months, minus the period of the second brood, when it is possible for this bird to injure fruit, but an examination of the stomach contents shows that less than one-half of its food consists of vegetable matter during these months, and that the major portion of this is composed of wild fruits. Separated and studied with the greatest possible care, not more than 15 per cent. of the total food consumed can be classed as belonging to cultivated fruits, whereas at least 30 per cent. of the food during that period consists of injurious insects and slugs and snails. What millions of caterpillars must be included in this item.

One hundred thousand Song Thrushes would in April, May and June, destroy upwards of $3,000,000,000$ insects and caterpillars, which are capable of destroying in fourteen days $\mathrm{n} \epsilon$ arly 10,000 tons of produce. Supposing this to be fruit, and estimating its value at $2 \mathrm{~d}$. per pound, it represents a loss of nearly $£ 200,000$. No one has ever suggested that the song thrush destroys anything like this amount, but we do very emphatically assert that it saves such a sum, or its due proportion, according to the number of birds. In other words, the sum total of the song thrushes activity is in the fruit growers' favour', and no investigation yet carried out supports any other viow.

In the light of what has been said, let us examine the nature of the food of a few of the commoner species of wild birds and the percentages of the different food items.

The Jackdaw. - Although the Jackdaw locally may be very destructive, it is generally a most useful bird. Of the total amount of food consumed annually, 71.5 per cent. consists of animal food and 28'5 of regetable food. The beneficial items include 39.5 per cent. of injurious insects, 4.5 per cent. of injurious insects, 4.5 per cent. of slugs and snails, and 4.5 per cent. of miscellaneous animal matter; the injurious items consist of 8.5 per cent. of cereals, 2.5 per cent. of clorer, 2.5 per cent. of potatoes and roots, 3.0 per cent. of fruit pulp, 2.5 per cent. of beneficial insects, and 4 per cent. of eggs, game birds and nestlings; the remaining 28.5 per cent. being of a neutral nature.

The Rook-Here we have a case of a bird decidedly beneficial in character, which owing to its rapid increase, and the increase of such birds as the starling, has been forced to supplement its food supply by preying upon cultivated crops.

The Starling.-We regard this species as one of the most injurious the fruit grower has to contend with, and year by year its preference for fruit becomes more manifest. At present it is a plague in the land and strong repressive measures are badly needed.

The House-Sparrow.-Whilst not a fruit eater to any great extent this bird does considerable damage by destroying the buds of the gooseberry and red currant; it is also reported damaging plums and apricots. It is such a plague in other ways and so numerous that its destruction is desirable.

The Chaffinch.-Destroys a few buds and some fruit, but the percentage is much too small to be serious; 16.5 per cent. of its food consists of injurious insects and 56 per cent. of wild fruit and weed seeds.

The Bullfinch. - Exceedingly destructive and should be destroyed.

The Great and Blue Tit.-Both of these birds deserve the scrictest protection, and fruit growers should be the first to see that they obtain it. The former species consumes 66.5 per cent. of injurious insects and the latter species 78 per cent., whilst 4.5 per cent. and 8 per cent. respectively consists of blossom buds and fruit pulp. Birds that consume such an enormous quantity of injurious insects must be of the very greatest value to the fruit grower, and if he can obtain such a valuable agent by the loss of a little fruit, he is getting the work done with the minimum of expense.

The Missel and Song Thrush.-Unless abnormally plentiful, as sometimes occurs in the 
south of England, we should recommend protection for both of these birds.

The Fieldfare.-We regret to learn that fruit growers in certain districts have been destroying this bird. As it only arrives in this country in October and leaves about the end of April or early in May, it does not affect the fruit grower; to the farmer it is a most valuable bird.

In addition to the above mentioned species there are a number of others that occasionally damage fruit, but they are seldom sufficiently numerous to prove serious, and in most cases they are birds that also consume large quantities of injurious insects.

We hive not mentioned the Blackbird as our investigations are as yet incomplete, but at present it is certainly much too numerous in certain fruit growing districts. The eggs should be collected and destroyed.
Conclustons.

In conclusion let us emphasise this one fact: viz., that the fruit grower has much more to fear from injurious insects than wild birds, these latter exercise a natural control of the greatest value, and while we are not at all in favour of all-round protection of all wild birds, we strongly recommend the greatest caution in any action of a repressive nature, and only on the advice and under the supervision of an expert.

While we must endeavour to keep under control all species that show an abnormal increase, it behoves us also to do all in our power to increase and protect the truly insectivorous species, especially the summer and autumn migrants. Any policy of general destruction will, we are sure, prove most dizastrous to the fruit growing industry. 


\title{
CHAPTER XXXI.
}

\section{SOME COMPARISONS OF FNGLISH AND AUSTRALIAN FRUIT GROWING.}

\author{
By Staff Sergeant-Major P. VaL. KerR, F.R.H.S. \\ (Former student at the Hawkesbury Agricultural College, at Richmond, New South Wales, and \\ Assistant in its fruit pollination trials.)
}

The following observations are made by an Australian fruitgrower during a few months' stay in Eogland. It is hoped that they may enlighten English growers as to some of the differences in fruit culture existing in the two countries. At the same time, our experiences may be helpful to our friends on this side of the world.

At the outset, it is necessary to compare the acreage of the orchards in both countries. In Australia, the land on which fruit is grown is all freehold, and the average plantation varies from 15 to 25 acres. These properties are usually cultivated by the owner with the help of employed labour, the former taking an active part in the work. In this country the plantations are considerably larger, and the owner seldom does any work, apart from superintending the various orchard operations. I should say that the foreman or bailiff in English orchards occupies a somewhat similar position to the owner of an Australian property, as far as labour is concerned.

\section{Systems of Planting.}

In Australia all trees planted for commercial purposes are propagated on free stocks, no dwarf trees being used for this object. Nearly all fruit trees are budded, gratting being but little practised. The orchard trees are usually planted in virgin soil on the square system, 20ft. by $20 \mathrm{ft}$, and no orchard fillers are utilised. For the first two, or possibly three years, vegetables or bursery stock are sometimes grown between the rows of trees. After that time, the whole of the ground is made available for the fruit trees. No berry fruits are grown between the orchard trees. By this method, one man can do al the necessary work on 10 acres of bearing orchard, a small amount of labour being employed during the fruit season.

In England the permanent orchard trees are generally interplanted with fillers (usually dwarfs), whilst between the main trees and the fillers, berry or bush fruits are grown. This method of planting entails a great amount of labour. With the present high cost of labour, it is questionable whether this system will be a payable one when the price of fruit becomes normal again.

\section{Cultivatron.}

During the whole of the summer in Australia, the orchard must be cultivated in order to keep down weeds and conserve moisture. The ground is plowed up to the trees in autumn, leaving the water furrows midway between the rows of trees. This allows all surplus moisture to drain away during the winter months. No cultivation is then done until the spring, when the plantation is agdin plowed. This time the land is plowed away from the trees, and the ground is left level for the summer, so that as swall a surface as possible is exposed for the evaporation of moisture. The soil requires frequent harrowing or scarifying during the hot weather, especially after a shower of rain.

Practically all the cultivation is done with horses. Now in this respect our methods are very different to those in vogue in this country. In English orchards where horse cultivation is practised, the ground is only plowed as near to the trees as the horses can work without interfering with the spreading branches. So far so good, but extension implements are apparently unknown in England, and, in many cases, quite a good portion of the ground is dug by hand. These extension implements make it possible for the soil to be cultivated right up to the trunks of the trees, so that practically no hand work is necessary, whilst the horses do not damage the spreading limbs of the trees. I have a case in mind in which all the digging required (1n a 10-acre block was done by one man in less than 8 hours! With the present high 
cost of labour the introduction of extension implements to this country is an absolute necessity.

\section{Proning.}

This subject does not seem to claim as much attention in England as it receives in our country, and I am sure a better knowledge of nur methods would be an advantage to the English growers, particularly to those cultivating apples.

Our trees are planted 15 months after budding, or 12 months after grafting, in the nursery, the trees being headed at from 9 to 15 inches from the ground, the particular height depending on local conditions. During the first three or four years the aim of the pruner is to establish a strong framework for the future tree, so that it may bear heavy crops, and not lose its shape. Consequently, bard pruning is the rule, little or no attention being paid to fruit-bearing. The trees are framed with an open centre to allow sunlight and air equal access to all parts of the tree. From 12 to 16 permanent leaders are allowed in the tree. After the fourth year, the grower prunes for fruit, but the framework is continued from year to year. This method of framing fruit trees is well worthy of attention by English growers.

In this country the pruning of the yearling lateral (that is, a lateral formed during tho past season) of applss and pears is very different to our method. With the exception of a few varieties of apples, we grow the bulk of our fruit on laterals. In England the crop is mostly grown on spurs on the main leaders. With some varieties this method answers well, but in nthers it is far from successful.

The terminal bud on this shoot is of ten a fruit bud, and by not cutting the lateral it may fruit during the ensuing season. At the same time fruic spurs will be formed nearer the base of the growth. Even if the terminal bud is a leaf buı, the fruit spurs will develıp in the same way, provided the shoot is not cut. The lateral may then be reduced in length, cutting to any one of these fruit spurs. This is necessary, as otherwise the extending of this growth wil: weaken the spurs towards the base, and they will eventually die. Our treatment of this yearling growth is to either cut it out entirely, or leave it severely alone. In selecting which laterals shall be left in, and which removed, we cut out the strongest and those growing upright, leaving the weaker and more horizontal ones.
The usual English method of treating this shoot is to cut it back to 2 or 3 buds at the base. With a few varieties, spurs will form during the next season, but with many kinds one, two or three more laterals will emanate from the cut growth. These in turn are cut back near the base with the same result, no fruit being obtained. Even if spurs are formed by this system, it is very doubtful if the grower is as well off as if he had treated the lateral by our method. Where he has, by the English style, two or three fruit spurs at the end of the second year, we have a lateral bearing four, six or more spurs. The English growers would be well advised to, at least, give this system a trial.

\section{Pests and Diseases.}

Whilst in Australia we have most favour able climatic conditions for fruitgrowing, we have also congenial conditions for the rapid multiplication and development of insect pests and fungoid disezses. Consequently a good deal of our time is occupied in coping with these troubles. The apple orchards are usually sprayed five times each year. At the same time, some of your worst pests are, as yet, unknown in our land, and it behoves us to make a very strict examination of all trees imported, as we have no desire to add to our already long list of orchard troubles.

The Apple Blossom Weevil has prevented a tremendous number of flowers from setting fruit this season. In some orchards visited, quite 50 per cent. of the blossoms were so affected. Should this pest ever get to Australia, I am afraid the apple growing industry would be in jeopardy. English orchards appear to suffer from leaf and bud-eating caterpillars far worse than those on our side of the world, and "Silver Leaf" in apples and plums (mainly the latter) is very prevalent in this country.

Our main pests are Codlin Moth, Woolly Aphis or American Blight, Peach Aphis and the various scale insects; while the fungnid diseases include Black Spot, Leaf Curl and Shot-holg. Bitter Pit is causing considerable damage, particularly in certain varieties of apples. No prevention or cure is known, but we are able to lessen its ravages by certain systems of pruning, manuring and cultivation. In the case of a very susceptible variety, the best plan is to cut the trees down and re graft with an apple more or less free from this trouble. 
The Codlin Moth, owing to our genial climate, has as many as six broods during the summer, and continual spraying with arsenate of lead is necessary to control the pest. As a preventative against Wonlly Aphis, which is very bad with us, all apple trees are propagated on blight-proof stocks, "Northern Spy" and "Winter Majetin" being commonly in use. This ensures that the roots will be free from the attacks of these insects.

For protection against the sucking insects (aphides and scales), we spray the trees during the winter months with a prepared oil (known commercially as "Red Oil"). I am surprised that this spray is unknown in England, as, although Woolly Aphis was only conspicuous in isolated cases, Mussel Scale was present in a number of orchards visited. This oil emulsifies readily with water, and is the best spray we have for this class of insect.

For the prevention of fungoid diseases, Bordeaux, Burgundy and Lime-Sulphur are used. Although pear scab is fairly bad in England, it was noticeable that the apple trees were particularly free fron black spot. Canker is considerably more prevalent in England than in Australia.

\section{SPRAYING.}

Owing to the different manner in which English and Australian orchards are planted, the methods of spraying (or washing, as it is termed in this country) vary. In English plantations, which are closely interplanted with nuts, currants, gooseberries, etc, it is obviously impossible to take a horse-drawn waggon between the rows of trees. In consequence, growers in this country have adopted various means to carry out their spraying. In some orchards a small handpropelled pump, with a capacity of about 15 gallons, is used; in others, permanent underground galvanized iron pipes are laid, having upstands throughout the orchard. Flexible howes are attached to these, the mixtule being pumped by an engine. Probably this is the best way to overcome the difficulty, but a great amount of lab ure is re yuired.

In Australia, us there is no interplanting of the ground between the trees, horse-drawn pumps are used. Both hand and power machines are in vogue, the latter becoming more popular each season. The hand machines are usually mounted on a cart or truck (a sledge is sometime's ust during the winter), and have a barrel nr vat of a capacity of 40 to $60^{\circ}$ gallons. The vehicle is drawn down between the rows, one man pumping, while anotber sprays. The power machines consist of a 60 to 200 gallon vat with a $1 \frac{1}{2}$ to $3 \frac{1}{2}$ h.p. motor, the whole mounted on is truck, and two or four rows of trees may be sprayed at once.

\section{LeginLation.}

In Australia the growing, sale and export of fruit are controlled by a number of Acts of Parliament. To the English grower, this, at first sight, might seem to make fruit growing in our country a hazardous vocation. Actually, the reverse is the case, these acts all being in the best interests of the conscientious grower, and protecting him against his would-be indiffarent neighbour. Each state is divided into districts, each under the jurisdiction of an orchard supervisor, whose duty it is to see that proper and sufficient means are taken to control pests and diseases, and also to give advice on any orchard problem. If the grower refuses or neglects to take measures against pests and diseases, the supervisor has the authority to have the trees cut down at the owner's expense. This course is now seldom necessary, although a number of trees wera thus treated shortly after the introduction of the Vegetation Diseases Act.

Not only aro we prevented from all.wwing disease to ravage our orchards, but we are not permitted to offer infected fruit for sale. We have also to sell our produce in cases of a specified $s^{\prime} z_{1}-$ for export the cases must be new. I understand that an act is now in force in one state to make the grading of fruit compulsory. This is a step in the righ, direction, and I hope the other states will follow the good example.

The Eaglish grower, unfortunately, comes under practically no legislation whttever. A Vegetation Diseases Act nas becomo law, but its provisions are not enforced, except in th. rases of Wart Disease in potatoes and Gooseberry Mildew. Thus, the conscientious grower sprays bis trees, and his lazy neighbouc keeps a splendid breeding ground for pests and diseases. Surely this is a terrible state of affairs for a country which was growing fruit bef 're Australia was even discovered! It is high time the Ministry of Agriculture woke up, and realized it responsibilities-enforce legislation, and protece the man who is trying to help himself and help Eagland, and mike the 
backward fruitgrower control the pests, or dig up his trees. Until this is done, English fruitgrowing will be seriously retarded.

Another advantage the Australian fruitgrower enjoys is that the salaries of orchard supervisors, and the cost of the many research experiments, are all paid by the Government, while in this country it is mainly left to private enterprise, and to a small extent to the county councils, Ministry of Agriculture, and contributions by the more zealous and public-spirited fruit growers. 


\section{CHAPTER XXXII.}

\section{A HISTORY OF FRUIT GROWING IN CANADA.*}

Fruit growing in Canada started with the first settlers. Champlain landed in Quebec Province on May 28, 1608, and we find reports of his having planted two gardens, one in the woods and the other in the meadows, early in that year.

He must have introduced fruit trees very soon after founding his infant colony, as Pierre Boucher, who wrote in 1663, says:-"In the woods there are wild plums, which are good, but not equal to those of France, and there are two kinds of wild gooseberries, prickly and smooth, besides black and red currants, also small red cherries, not bad, and another kind that is not so good. The quantity of raspberries and strawberries is incredible; they are larger and better flavoured than those in the gardens of France. There are also blackberries and blue berries, besides many others whose names I do not know. There is abundance of wild grapes, very sour, but they would doubtless improve under cultivation. Some people have introduced grapes from France into their gardens, which bear large and beautiful fruit. Not many trees have yet been introduced, except some apple trees, which bear very fine fruit in large quantities."

Besides this we have the historical sketch of the "Fameuse" apple, showing that apple-growing had a very early origin in Quebec. The Fameuse originated in the French settlement on the St. Lawrence from seed brought from France between 1608-1650. It is generally believed that this was done by the Sulpician Fathers, the earliest missionaries to establish themselves on Mount Royal, bringing with them from France seeds of the best French apples to plant in the virgin soil of the Island of Montreal. The Fameuse of today is the result of the early selection of

*Abstracted by Cecil H. Hooper from an article by Geo. Dickson in Macdonald College Magazine, 1916-17. seedlings by these monks. Montreal was founded in 1642, and by 1700 this variety had been distributed quite freely through Quebec and Vermont.

Outside the Island of Montreal the chief fruit-growing sections in Quebec have been in the Abbotsford district. In 1812 the fruit-bearing orchard (seedlings) began fruiting. Some grafted trees had been brought to Abbotsford in 1810, but no grafting was done in that district until 1823, when it was introduced by Samuel Jackson. The first budding was done in 1846. In 1827 several plantings of Fameuse, Pomme Grise and Bourassa were made in that district. The first commercial nursery was established in 1857 by N. C. Fisk. Others followed, and in this way thousands of trees were distributed through the Province.

In December, 1874, the Fruit Growers' Association of Abbotsford was organised, the pioneer society of the Province. It issued letters of inquiry and gathered information from the experience of over one hundred growers in the Province outside Abbotsford, and in 1875 published a "Fruit List for the Province of Quebec." In 1876 it held its first exhibition of fruits, vegetables and flowers. In 1879 the society received its first Government grant. Spraying was introduced in 1890, when Bordeaux mixture with Paris green was applied by hand pumps. In 1894 the Pomological and Fruit Growers' Association of the Province of Quebec was organised at Abbotsford; the province was divided into nine districts, each one having a director as exists to-day. People grew hay in their orchards, leaving the aftermath to lie as a mulch: others grazed sheep in their orchards. To-day the general practice is clean cultivation, for the first ten years crops, such as, beans, pumpkins, cabbage, root crops and potatoes are grown in the orchard. When the trees come into bearing these crops 
are discontinued, Juring the growing season the orchard is culfivated once every 10 days until July 1, when a cover crop of clover or rape is sown to ripen off the wood of the tree before the fall and to colour up the fruit.

The export of apples from Quebec started in 1896. Boxes were used for Duchess, Fameuse, Wealthy and McIntosh, and barrels were used for Golden Russets and Canadian Reds. The packing in boxes has now proved itself a good practice. There are now in Quebec Province $1 \frac{1}{4}$ mil- lion trees in bearing, and nearly another million non-bcaring trees. There are 36 fruit stations in the Province, established by the Provincial Government, from which advice may be obtained and where different tests are being carried out. There are seven demonstration orchards, in which spraying, pruning, cultivating, \&c., are shown. These have been a success everywhere. Shipping experiments are tried and new markets sought; 1,235 demonstrations were given in differnt orchards in one year. 


\title{
CHAPTER XXXIII.
}

\section{SOME FUNGOUS DISEASES OF FRUIT TREES.}

\author{
By H. Wormald, D.Sc. (Lond.), A.R.C.Sc., Mycological Department, South Eastern \\ Agricultural College, Wye, Kent.
}

I.-INTRODUCTION.

Fungi are forms of plant life which obtain their nutriment from substances produced by other organisms. Some fungi live on dead organic products only, while others are either wholly parasitic and unable to exist except on living tissues, or they may adopt a parasitic life when conditions are favourable to their mode of attack. Many of the parasitic forms cause great damage to fruit trees, and the grower should be able to recognize those which occur most frequently so that he may take steps to prevent epidemic outbreaks of fungous diseases, some of which are now so prevalent that preventive measures against serious loss are adopted by the progressive fruit grower as part of the general routine work on fruit farms.

The fungi are reproduced by spores which are so minute that they are easily blown in the wind, or carried about by insects. This fact explains the appearance of diseases in places that were previously free, and also shows how a neglected orchard is not only uneconomic to the owner, but may also be a source of danger to other orchards in the neighbourhood. The microscopic size of the spores also renders possible their distribution from place to place on farm implements or on workmen's tools or clothes.

The methods to be adopted in combating the parasitic fungi must necessarily vary with the mode of parasitism of the organisms. A treatment that would kill or effectively keep in check such forms as the powdery mildews (Erysiphacerce) which penetrate no further than the epidermal cells, would be useless against the apple canker fungus which extends into the woody central cylinder of stems and branches. The characteristic features (as seen by the naked eye) of the more important diseases of fruit trees caused by fungi are briefly described in the following article, to enable the grower to identify them in the orchard or plantation, and methods by means of which he can keep them under control are given in each case.

\section{II.-Con'rrol Measures.}

Apart from the principles involved in breeding varieties resistant to disease (which are outside the scope of this article), the first general rule in disease control in the plantation or orchard is to render the conditions under which the trees are growing favourable for strong sturdy growth. They must be grown in suitable soil, with adequate drainage, and must not be over-crowded, for free access of air and sunlight to all parts of the tree is necessary for healthy growth. Weak, "sappy" shoots often fall a prey to disease when a stronger growth would be resistant. In spite of such hygienic precautions, however, some diseases will probably sooner or later appear, and steps must be taken to stamp them out, or at any rate to prevent their assuming epidemic proportions. Neglect in dealing with a disease on its first appearance has often led to disastrous results.

The measures which must be adopted to keep fungous diseases under control come under two main categories, viz., (1) destroying the actively growing fungus and its reproductive oigans; (2) covering those parts of the tree liable to infection, by some protective covering which will prevent the penetration of the germ tubes of the spores. The first of these should be adopted wherever practicable and in certain cases it is the only effective means 
of control. On the other hand, to prevent infection by the application of some substances which forms a protective covering is common practice against some diseases and often sound, clean fruit cannot be obtained unless such preventive measures are taken. A fluid used in this way must be applied by some form of apparatus producing a fine mist-like spray which penetrates to all parts of the tree, and is

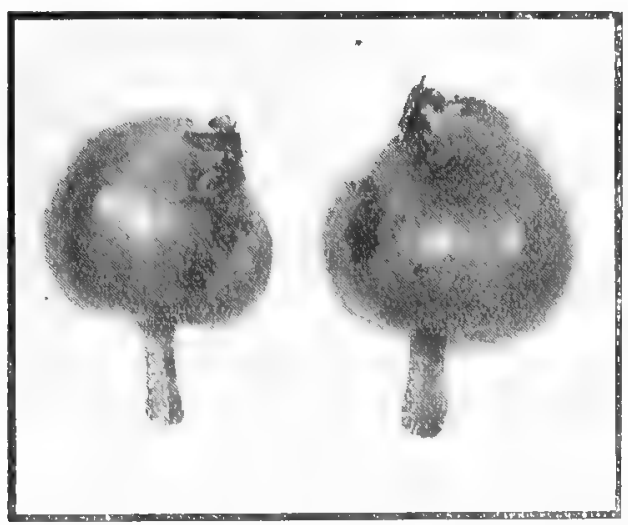

FIG. 1.- Toung Ipples affected by Scab.

deposited in minute drops, which on drying leave a more or less continuous covering of a fungicidal substance.

\section{III.-FUNGICIDES.}

There are two fungicidal spray fluids with which all fruit growers should be familiar, viz., Bordeuux Mirture and lime-sulphur. The former is a good protective wash against black spot or scab of apples and pears; the formula recommended for its use on fruit trees is $8: 8: 100$, i.e., 8lbs. copper sulphate and 8lbs, quicklime to 100 gallons of water. The best way of preparing the mixture is as follows :-

(1) Dissolve 8lbs. of copper sulphate in 8 gals. of water.

(2) Place $8 \mathrm{lbs}$, of freshly burnt quicklime in a wooden vessel, and slowly slake by adding a little water from time to time until the lime breaks up to form a thick paste, then add more water to make up to 8 gals. of "milk of lime."
(3) Run off 84 gals. of water into a barrel or galvanized iron tank, add the 8 gals. of milk of lime, passing it through a strainer to remove the coarser particles, then add slowly, stirring meanwhile, the 8 gals. of copper sulphate solution.

The mixture should be used within 24 hours of its preparation. The " milk of lime" and the copper sulphate solution remain unchanged however until they are mixed together, and so may be prepared in larger quantities as "Stock Solutions "; the Bordeaux. Mixture may then be made as required.

Lime Sulphur is sold as a concentrated solution which only requires to be diluted with water. The most reliable brands are prepared of a specific gravity of 1.3; one gallon of the concentrate when diluted with 14 gallons of water (giving a S.G. of 1.02) forms a useful winter wash for cleansing fruit trees from moss and lichen. For spraying the foliage in summer $1 \mathrm{gal}-$ Ion to 29 gallons of water (S.G.1.01) may be used on some trees, but often further dilution is necessary or scorching of the leaves and fruit will result.

$$
\begin{gathered}
\text { IV.-Diseases. } \\
\text { "Black Spot" or "Scab" of Apples } \\
\text { and Pears. }
\end{gathered}
$$

One of the most troublesome pests of the fruit grower is the fungus renturia Pomi (= Fusicladium dendriticum) which causes the diseases known as "Apple Scab." Black or brownish spots appear on the fruit, often while it is still quite small; these spots develop into circular scab-like areas up to about $\frac{1}{4}$-inch in diameter, or large irregular scabs are formed when two or more spots coalesce. Not only is the fruit seriously disfigured, but when it is attacked when very young and rapidly increasing in size, growth is retarded on the affected side thus producing a malformed fruit (Fig. 1). If the apples become infected at a later stage in their growth they may develop normally except for the appearance of the black spots which diminish their market value. If scabbed apples are stored a rot of the fruit may occur, caused not by the scab fungus itself, but by other forms which are able to enter at those places where the skin has been ruptured at the scabs. 
The fungus infects not only the fruit but also the leaves and the young shoots. On the dark brown spots which appear on the leaves numerous spores are produced which, falling on the fruit, cause infection of the crop. When the young shoots are attacked the fungus lives within the tissues through the autumn and winter, and in the following spring bursts through the bark as small cushionlike pustules. This rupturing of the bark causes the twigs to have a roughened cankered appearance, which is a characteristic feature of this disease. Spores are formed on the surface of the pustules and these under favourable conditions reproduce the disease on the new season's leaves and fruit. It is evident therefore that the fungus is able to persist from year to year on the infected twigs, and when practicable these should be pruned off and burnt.

A closely related fungus, Venturic Pyrina is the cause of a similar disease of pear trees, the fruit, leaves and shoots becoming affected; the fruit is, as a result of this disease, very frequently malformed and cracked.

As a preventive against infection by the scab fungi, a protective spray should be applied to the trees. Bordeaux Mix ture and Lime-sulphur are both effective washes for use in the control of this disease. Bordeaux Mixture of the formula $8: 8: 100$ is safe for use on pear trees and some varieties of apples, but on others a scorching of the leaves and fruit occurs, and Lime-sulphur is preferable. In the case of certain varieties which are very susceptible to spray injury, e.g., Cox's Orange Pippin, Lime-sulphur at half the usual summer strength, i.e., S.G. 1.005 (one gallon of the concentrate at S.G. 1.3 to 59 gallons of water) must be used to avoid scorching.

The first spraying should be carried out on the young foliage just before the flowers open, and a second as soon as the fruit has formed; where the disease has been severe in previous years a third spraying may be necessary.

\section{Apple Mildew.}

When the young apple shoots are elongating in spring it is frequently found that the leaves on some of the shoots are checked in growth, and coated with a white powder which consists of the spores of the Apple Mildew (Podosphaera leucotricha). The flowering shoots may also be attacked, the flowers in consequence becoming deformed, and fail to set into fruit. The disease may also extend to the very young fruit, and occasionally it occurs on older apples. On some varieties the leaves may be so severely affected that many are killed and fall off, leaving a number of bare twigs.

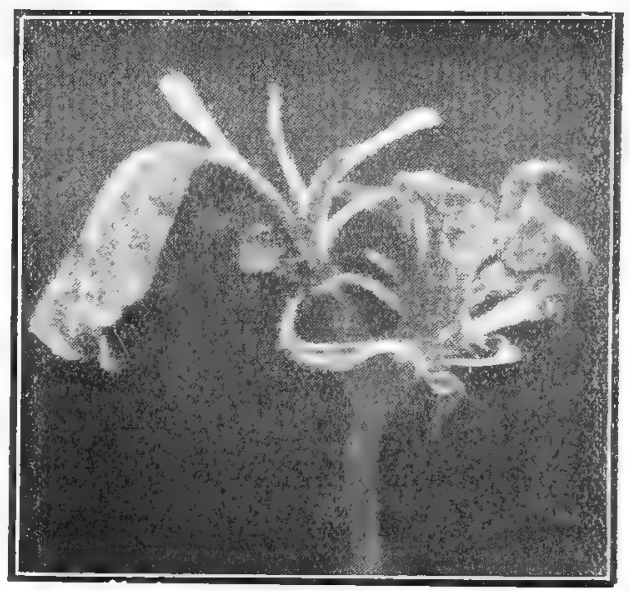

Fig. 2.-Apple Mildew.

In addition to the powdery summer stage this fungus (in common with other powdery mildews) produces fructifications which persist through the winter and disperse their spores in spring; these winter fructifications in the apple mildew are, however, of infrequent occurrence, and its usual mode of surviving the winter is by the development of hibernating mycelium (non-fruiting fungal threads) in the buds of the young twigs. The leaves which grow from such infected buds again give rise to the powdery summer stage, and the spores, on being blown about, start new infections.

All infected shoots should be pruned off and burnt; these may be distinguished in spring and summer by their white, mealy leaves (Fig. 2), and in winter by the grey or whitish appearance of the 
bark. To protect the leaves from infection from without they should be sprayed with lime-sulphur just before the flowers open, and again, if necessary, immediately the fruit is formed, as recommended for Apple Scab.

\section{Apple Canker.}

A fungus, Vertrin ditissimu, is the cause of cankers often found on apple and peir trees (Fig. 3). It gains entrance through wounds and large cankers on the

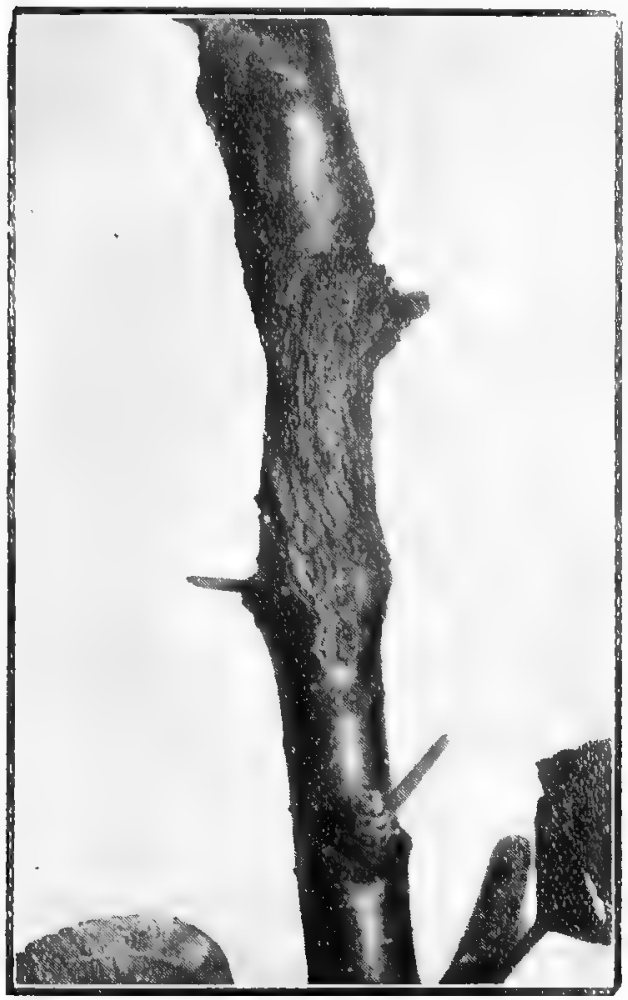

Frg. 3.-1 Canker which has nearly girdled an Apple Branch.

main branches may arise in this way. On neglected trees such branches are eventually girdled by the cankers and killed. Young twigs may become infected through the buds and, on some varieties of apples and pears, the dying back of the young branches by cankers originating through infection at the nodes is of frequent occurrence. During the summer the fungus is to be seen on the surface of the young cankers as whitish pustules bursting through the bark. Each pustule produces numerous spores, which, on becoming detached and dispersed to other parts of the tree or to other trees in the neighbourhood, give rise to new infections.

To keep the disease in check it is necessary therclore to cut out and burn the cankercel portions as soon as they are observed, for not only are they injurious to the branches on which they occur, but they are a source of further infection. In those cases where the cankers have girdled or nearly girdled the branches! this operation involves cutting back to below the diseased part. Where the cankers have extended but a little way round the branches the cankered portions should be cut out, care being taken that all discoloured wood and bark is removed; the wound should then receive a coating of Stockholm tar, in order to protect the exposed cut surface from further infection, until it becomes naturally covered over by callus.

If the cankers are allowed to remain on the trees throughout the winter the fungus produces fructifications of another form which are seen as minute red globules in the cracks of the cankered bark. The spores which develop within these fructifications are set free and dispersed in the spring, thus providing for fresh outbreaks of the disease.

\section{Brown Rot Diseases.}

Of the rarious forms of disease caused by the Brown Rot fungi, Monitia (Selerotinia) fructigena and Ionilia cinerea, the most familiar is a rotting of the fruit. The Brown Rot of ripening apples is caused by Monilia fructigend which, on gaining entrance through a wound in the skin, spreads rapidly through the flesh, and soon appears at the surface as yellowish tufts (Fig. 4), often produced in irregular concentric circles round the point of infection. The tufts become powdery with innumerable minute spores which are borne in the wind from the diseased fruit to others on the same tree or on surrounding trees. Apples in contact with diseased ones become infected by contagion, and thus 
the whole of a cluster may be destroyed from infection arising in one of them. Some of the diseased apples fall to the ground and rot away, but others remain on the tree and gradually become shrunken and wrinkled; in this " mummified" condition they remain until the following summer, when the fungus redevelops and infects the new crop.

On certain varieties, e.g., James Grieve and Lord Derby, the disease extends from the affected apples to the fruiting spur, and may even cause cankers on the branches.

The rot may continue after the fruit is picked; hence the necessity of careful sorting at the time of storing and packing, for all apples showing a trace of rot should be

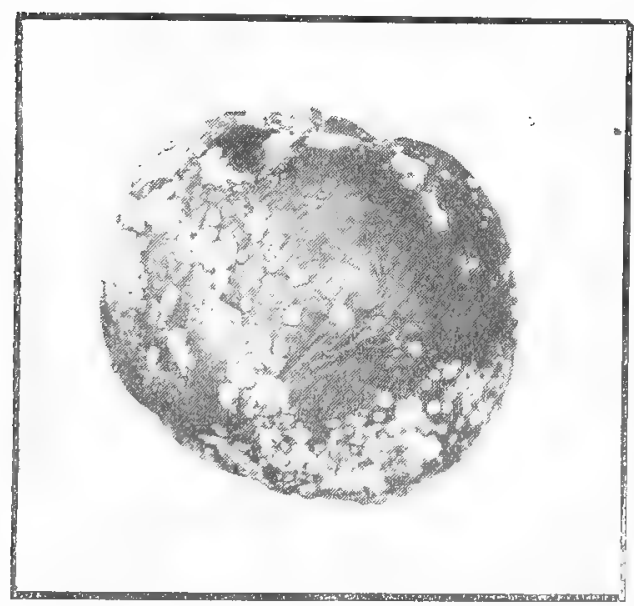

Fig. 4.-An Apple with Brown Rot-" Monilia Fructigena."

rejected. In the case of apples affected when stored, the discolouration, at first brown, becomes darker until often it is quite black.

The same fungus also occurrs on pears, plums, cherries, damsons and peaches. causing, as in the apple, a brown rot of the fruit.

Monitia cinerea is more dangerous than Monitia fructigena, for it not only produces a brown rot of fruit, but in plums and cherries causes, in certain seasons, a serious Blossom Wilt, the flowers becoming withered and blackened as though killed by frost; it also kills the twigs and may invade the branches, thus causing gumming and cankers. On plum trees a condition which has been called the "Wither Tip" disease is of frequent occurrence. In this case the fungus attacks the young shoots of the current year through the newly unfolded leaves, with the result that the terminal portion of the shoot wilts and becomes dry and withered. These withered shoots may be recognised in winter by the fact that they usually retain some of their withered leaves, and if such shoots are examined in spring, the fungus will be seen as grey pustules bursting through the bark; the spores which develop on these pustules serve to infect the flowers and young shoots as they unfold.

A form of Monitia cinerea is responsible for a serious "Blossom Wilt and Canker Disease " of apple trees. Infection takes place through the flowers which are killed in the course of a few days, then as the fungus invades the spurs, the leaves round the base of the flowers begin to wilt; this withering of the leaves on the flowering spurs is the first obvious symptom of the disease, and is seen about a fortnight after the trees come into blossom. When the spurs are short the disease soon extends into the branches, and cankers are produced, often resulting in the girdling and subsequent death of large branches.

The fungus lives through the winter in the dead spurs, and in the cankers, and by the following spring develops a number of small grey, cushion-like tufts (see Fig. 5), on which are produced the spores which infect the flowers as they open. The disease occurs on many varieties of apples, but some are more susceptible to it than others, e.g., Lord Derby, James Grieve, Ecklinville and Cox's Orange Pippin. The most effective way of controlling this disease is to cut out all dead spurs during the summer when they are readily recognised by reason of their dead leaves, but care must be taken to remove all dead and discoloured wood and bark, and if cankers have been produced, these, too, must be cut out; if the operation is delayed until winter, the dead spurs are not so easily distinguished.

Spraying is not to be relied upon to keep 
down the Brown Rot diseases; it is essential to remove and burn all sources of in-

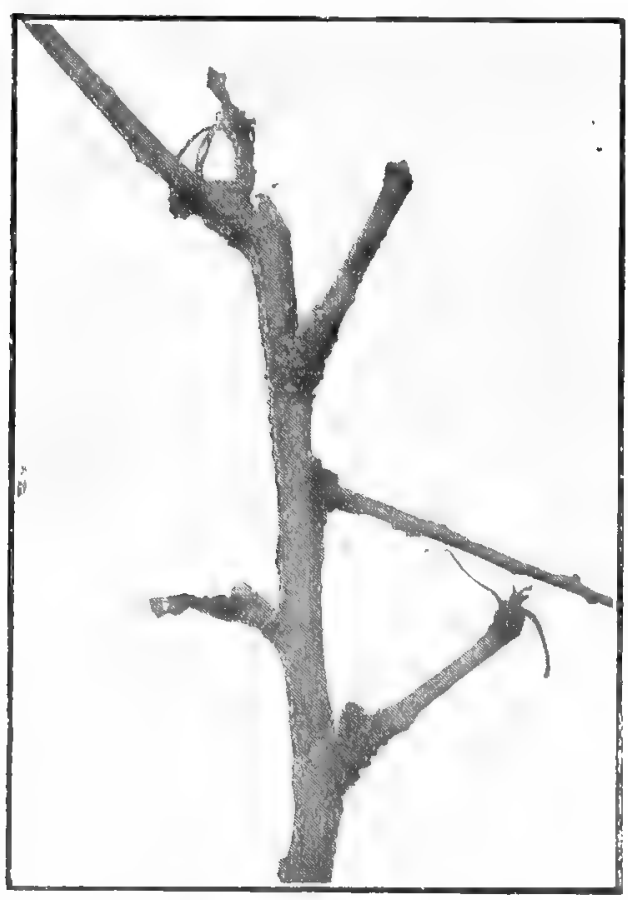

FIG. 5.-Two Mummified Plums with Pustules of Monilia Cinerea.

fection, e.g., mummified fruit (see Fig. 6), dead spurs, twigs and canker.

\section{Silver Leaf Diselse.}

A disease, which must now be familiar to all who cultivate plum trees and against which the grower should exercise drastic measures, is that known as "Silver Leaf Disease," from the fact that the leaves of the affected trees have a silvery sheen, showing a striking contrast with the normal dark green leaves of healthy trees. Victoria Plum trees are very susceptible to attack, and in this variety great numbers of affected trees have been killed outright by the disease in recent years. It is important that growers should realise the infectious nature of the disease and make every effort to stamp it out when it first appears in a plantation. The fungus, Stereum purpureum, which is the cause of the disease, is not found in the leaves, but in the tissues of the branches and stem. Sooner or later the affected branches die, and then the fungus appears at the surface of the bark as bracket-like outgrowths, usually about one inch in length (Fig. 7); these are the fructifications of the fungus, and trees which bear them are

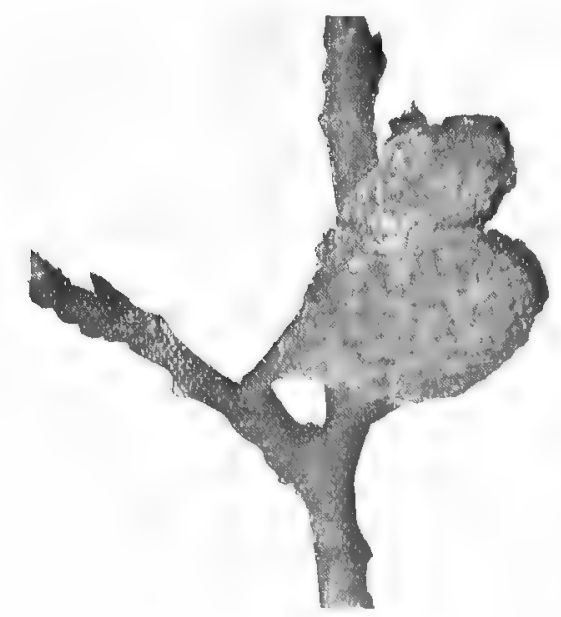

IIr. 6.-The Blossom Wilt and Canker, Disease of the Apple Tree, pustules of the fungus on a dead branch in winter.

a source of danger to those around, for the fructifications produce innumerable spores which are borne on the wind to other trees. Branches or trees with silvered leaves should be promptly removed and burnt before the fungus produces its fructification. The dead stumps of such trees should not be left, as these often become covered with these fruiting bodies; nor should the dead stems and branches be allowed to remain on the ground after they are cut down, or the fungus will continue to develop and produce its spores.

Stereum purpureum is a wound parasite, thus care should be exercised to avoid injuring the trees as far as possible. Where practicable, branches bearing heavy crops should be supported to obviate the rupture that might otherwise arise at the junction with the stem. 
Although the disease is most destructive to plum trees, it is not confined to them,

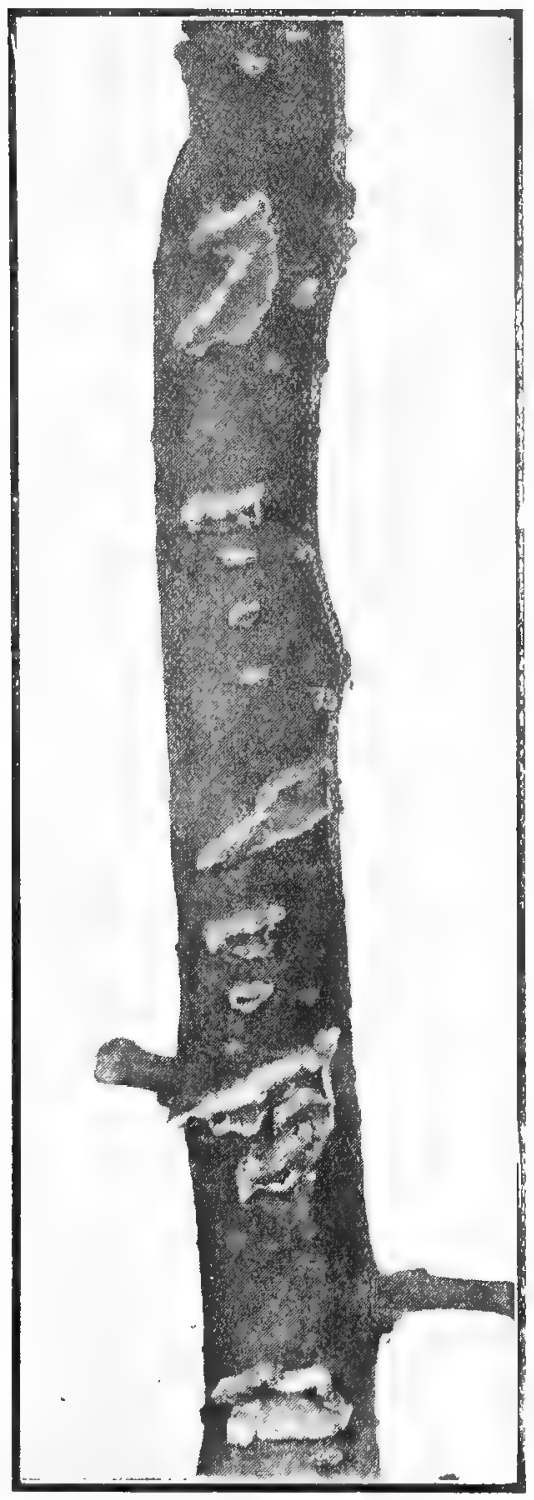

FIg. 7.-The Silver Leaf Fungus, Stereum purpureum, on a dead branch of a Victoria Plum Tree. and the apple, cherry, damson, apricot, currant and gooseberry are liable to infection. It also occurs on such trees as laburnum and Portugal laurel.

Sometimes the scions of recently grafted apple trees show silvered leaves one year and later become normal. It is advisable therefore, in such cases, not to destroy the scions immediately; if, however, they succumb, they should be removed and burnt without delay.

\section{Gooseberry Mrldew.}

Gooseberry bushes are liable to infection by two powdery mildews. One of these, known as the American Goosebe:ry Mildew (Sphaerothec'a mors-uvae), is the most troublesome fungus pest that the gooseberry grower has to contend with. It makes its appearance in spring, often

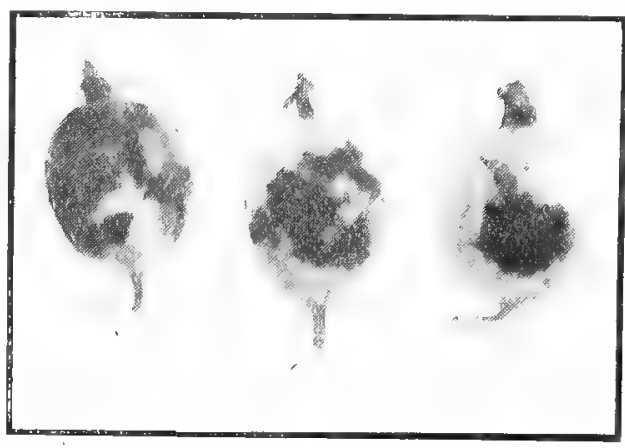

FIG. 8.-Gooseberries, showing the brown winter stage of the American Mildew.

in May, and even sometimes in April, as a whitish powder on the young leaves. As the shoots elongate the mildew grows over the tips and may extend downwards along the surface of the shoots for several inches. The fungus later becomes darker in colour, and eventually forms a dense, dark-brown, felted film, covering the affected parts.

When the berries are formed they too become attacked; here again the fungus is first seen as white powdery patches, which later become brown and felted (Fig. 8). If the berries become infected when quite small they may become completely covered with the fungus, and in consequence are preverted 
from growing out to their full size. At the white powdery stage the disease is very infectious, for the powder consists of chains of spores which are blown away in the wind and carried considerable distances, thus giving rise to outbreaks in plantations and gardens where it has not previously occurred. A diseased plantation thus serves as a sourse of infection for others in the neighbourhood.

As the fungus assumes the brown colour it develops fructification of another form which may just be scen with the naked eye as minute black specks embedded in the brown felted layer. In the following spring these fructifications burst and, from them, spores are forcibly ejected into the air; if these spores reach the voung gooseberry shoots or fruit, infection again breaks out.

Control measures consist of (1) removing and burning infected shoots bearing the over-wintering fructifications; (2) spraying the bushes with a fungicide which will protect the berries and young shoots. The most useful spray fluid, at present known, for the latter purpose is the lime sulphur solution; where there has been a severe attack during the previous season the first application should be made soon after the leaves unfold, and later spraying should be carried out at intervals of about ten days or a fortnight. On some varieties the lime-sulphur can be used at full summer strength (sp. gr. 1.01), e.g., Cousin's reedling and May Duke; on other e.g., Berry's Early, Crown Bob, and Lancashire Lad, the solution should be used at half that strength (sp. gr. 1.005), while Yellow Rough and Valentine's Seedling are varieties so susceptible to spray injury that sulphur washes should not be used on them.

One disadvantage to the use of limesulphur spray is the whitish deposit which is left on the berries causing them to be disfigured. This is obviated by replacing the lime sulphur by the ammonium polysulphide and soft soap wash as the fruit approaches maturity; the latter is an effective fungicide against the mildew when in the white powdery stage and leaves no visible deposit on the leaves or fruit. The concentrated solution of ammonium polysulphide as supplied by the manufacturers should be so diluted that the wash contains 0.11 per cent. polysulphide sulphur and instructions for obtaining such a dilution should be supplied with the concentrate.

The European Gooseberry Mildew, Hicrosphaer" "roswlarise, also infects the foliage of the gooseberry, but as it does not extend to the fruit it is far less harmful than the American Gooseberry Mildew.

\section{"Die-Back" of Gooseberry Bushes.}

Another disease of gooseberry bushes is one which frequently kills the branches, or even whole bushes, outright. Infection often occurs on the main stem near the ground level, and as the fungus extends round the stem the bush is killed. The young shoots, leaves, flowers and fruit are also points of attack. When the leaves are infected they become grey or whitish round their margins, and in a severe attack fall off prematurely.

The fungus, Botryl is cinerre (Sclerotinia Fuckelianu), which causes the disease is to be seen, particularly during damp weather, on the surface of the affected parts as grey powdery tufts, which on the fruit and flowers often coalesce to form an almost continuous layer. These fructifications produce numerous spores which are scattered by the wind and blown to other bushes.

Affected bushes should be uprooted and burnt; if singıe branches are killed they should be pruned off and similarly destroyed. As the fungus can continue to grow on the branches and stems killed by it, the prompt destruction by burning of these is essential to the complete control of the disease. Where the disease has been prevalent during the preceding season, the bushes should be sprayed with Bordeaux mixture, as soon as the fruit has set, in order to prevent leaf infection.

\section{Cherry Leaf Scorch.}

The presence of this disease on cherry trees is denoted by the characteristic feature that on affected trees the leaves which become infected do not fall in autumn, but remain in a withered condition on the trees throughout the winter until the leaves and flowers appear in the following spring. The cherry leaf scorch fungus, Gnomonia erytlarostoma, infects 
and lives within the tiss $x \in S$ of the leaves and continues to develop during the winter, producing its fruiting bodies which shed spores on the flowers and young leaves as they unfold.

The most certain method of dealing with this disease is to collect and burn the dead leaves before the young foliage unfolds; this has been found to be both practicable and effective. Spraying the young leaves with Bordeaux mixture will check the disease, and this method should be employed where scarcity of labour prevents the carrying out of the first method of control.

\section{Peach Leaf Curl.}

This disease, familiar to most growers of peaches, is characterized by the abnormal character of the affected leaves, which are thick, fleshy, curled, and wrinkled (See Fig. 9); they are paler than the healthy leaves, often yellowish or reddish, and become covered with a grey or

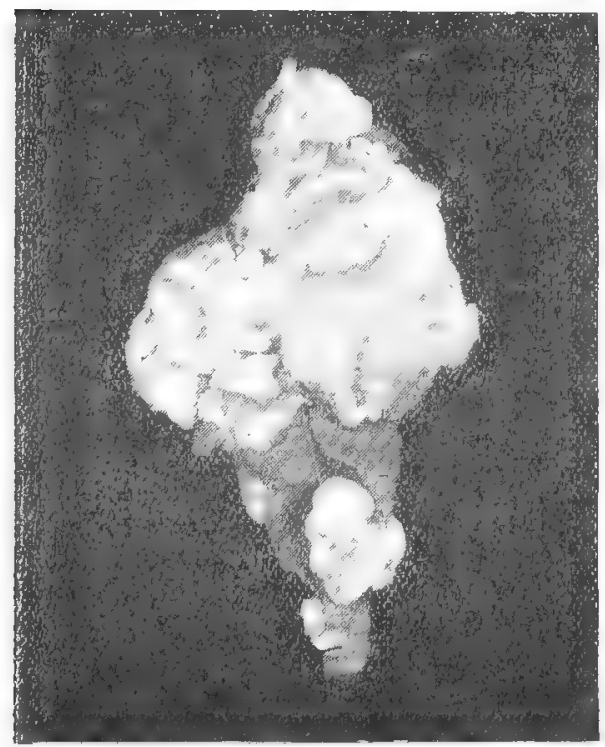

FIG. 9.-A peach leaf attacked by the leat curl fungus, Exoascus deformuns.

whitish bloom. The fungus Exoascus deformans, growing within the tissues of the leaves, eventually develops its fructifications in a thin layer covering the epidermis, and the spores liberated from these fructifications serve to reproduce the disease on other leaves. Finally, the affected leaves are killed and fall off before the normal time, and, when serious defoliation occurs, the vigour of the trees is impaired; the crop in consequence suffers in quality and amount. The fungus also extends into the young shoots, which, as a result of the infection, become. somewhat swollen and stunted.

To control this disease infected shoots should be pruned off and burnt, and the trees should be thoroughly sprayed with a fungicide in winter before the buds open; for the latter purpose Bordeaux mixture $(6: 6: 50)$, Burgundy mixture or lime-sulphur (concentrated solution sp. gr. 1.3 diluted 1 in 15) may be used.

\section{Crown-Gall.}

A disease which has hitherto received little attention in this country is one which is of interest to the practical fruit grower from the fact that young fruit trees are liable to infection, nursery stock in particular often becoming affected. The disease is similar to one which is common in America, and has been under investigation in the United States for a number of years; it was found to be caused by an organism which has been named Bacterium tumefaciens. Crowngall is known to occur in this country on the apple, pear, plum, rose, raspberry, and loganberry.

The galls are usually produced at the base of the stem just below the ground level, but they also occur on the roots at some distance below the level of the soil; they are therefore not visible until the tree is uprooted. They are irregular outgrowths, frequently of some considerable size, and when occurring on the stem itself may be several inches in diameter. Eventually they slowly disintegrate and the organisms are set free into the soil which thus becomes contaminated.

When the grower is planting up fruit trees he should examine them carefully and reject all those which are affected with these abnormal growths. Where nurseries are infested with the disease the owner should endeavour to raise young trees free from the disease by starting with clean stocks in ground where crowngall has not previously occurred. 


\title{
CHAPTER XXXIV.
}

\section{THE COMMONER FRUIT PESTS.}

\author{
By C. A. W. Duffield, F.E.S.
}

(Lecturer in Agricultural Zoology, South Eastern Agricultural College, Wye, Kent).

It is essential for the fruit grower to have some knowledge of entomology before he sets out to wage war on the many different insects he is likely to find damaging his fruit.

Firstiy, he should be acquainted with the method of feeding of the particular pest he is out to destroy; secondly, he should know something of the life history and different changes through which insects pass before arriving at the mature stage. Broadly speaking, insect pests are divided into two groups, viz., (1) those provided with mandibles or biting mouths and (2) others whose mouths consist of a longish tube which pierces the plant tissues and enables the creature to suck the juice of the plant.

Those provided with mandibulate mouth parts devour their food wholesale and may thus be poisoned, but the group with sucking or haustellate mouth parts escape any poisonous substances applied to the outside of the leaves.

As insects breathe through pores in their bodies we are able to deal with creatures in this second group by suffocation, that is, by applying a wash which will adhere to the body and stop up the breathing pores of the creature. In cases where it is impossible to reach the insect with a wash we must resort to trapping or soil treatment.

In dealing with injurious insects in this article we will divide them up under headings according to the particular fruit tree they attack.

\section{APPLE.}

Apple Psylla or Sucker is often a serious pest. As soon as the buds begin to expand, the minute yellowish eggs which pass the winter on the twigs and at the base of the buds, begin to hatch. They find their way to the opening bud, the young, wingless sucker at once commences to suck the sap, thus werkening the growth. In time they mature and become winged, but resort to jumping rather than flying. A heavy dressing of lime and salt wash in February, or lime alone may be used right up to the time the buds are bursting. The eggs are covered up with a coating of lime and so the young are unable to hatch out. Should this not have been done, a nicotine wash used directly the trusses are open will kill the young sucker.

THE Woolty ApHis.-Too well known, especially in old neglected orchards, to need any description. In dealing with it, the fact that it lives also on the roots is apt to be forgotten. When seen on the tree above ground apply with force a spray of Paraffin Jelly, especially on the patches of white wool. At the same time inject carbon disulphide, four injections of $1 \mathrm{oz}$. each at a distance of one foot from the trunk. Tits do an immense amount of good by destroying this insect in winter. The soft-barked varieties of apple, such as ('ox, Ribston and Blenheim, seem to be the most susceptible to woolly aphis.

Aphides.--We find three other species doing damage to apple, the Rosy Aphis, Permanent Apple Aphis, and the Migratory Apple Aphis. The first and second hatch out early and feed on the buds as they are developing. We find a second brood about the time the bloom is out. The insects cause the foliage to curl and they live within the curled up leaves. The Rosy Apple Aphis causes reddish blotches to appear on the leaves. The Migratory Aphis lives for a time upon the apple and then flies off to corn and grasses, flying back to the apple in the autumn for the females to lay their eggs. 
As these insects are difficult to deal with when once they have curled the leaves we must look to their life history to find out some other stage at which they can be attacked. The winter is passed in the egg stage, these are minute shiny, black bodies and may be found at the base of the buds and on twigs. The same method should be adopted as for the apple sucker. Lime and salt for the eggs and nicotine for the aphis. By this means we kill two birds with one stone. Soft soap and quassia may be used, and is perhaps considerably cheaper, but by using nicotine we also destroy the young larvae of the

Wrater Moth.-This is another of the cormmon apple pests. The male is a greyish winged moth, while the female has only rudimentary wings. The moths commence to emerge from the ground in October, and the wingless females at once climb the tree to deposit their eggs. If a band of specially prepared grease be placed round the tree trunk by or before the beginning of October these females will be caught on their way up the tree. Fallen leaves, and even the bodies of the moths are capable of being used as bridges over the grease, so the bands should not be neglected when once on All leaves, etc., should be moved. If this method has not been resorted to and the eggs have hatched into little green "looper" caterpillars, a nicotine wash will kill then if applied when the buds are opening, and before the caterpillars are large. "Winter Moth" is a term now apparently used for all moths with wingless or semi-wingless females hatching out between October and February. Besides the true winter moth we often find another looper caterpillar which is the larva of the

Mottled L.Mrer Mot'r, which also does a large amount of damage. The caterpillar is rich brown in colour on the back, yellow on the sides and underneath. As the female moth is quite wingless it also has to climb up the tree before depositing its eggs, so they can be caught on the same grease band.

The Lackey Morit. - The larvæ of this moth live in colonies for two-thirds of their existence under cover of "Tents" made up of masses of web. As they devour the foliage they move along the branch, and when particularly abundant clear off all foliage and young fruit. When full grown they are about two inches in length, slightly hairy, and striped with blue, black and orange. At this period they leave their "tents" and spread over the trees. When full grown they spin up amongst any remaining leaves and in due course hatch out into foxy red moths often with a darker band of the same colour across their wings. The females lay their eggs in compact rings round the twigs of the food plant. These egg "rings" are often found during pruning operations and should then be destroyed. If any remain, they will hatch out, the caterpillars forming their conspicuous tents. These nests of caterpillars should be cut out and destroyed as soon as they appear. If left the inmates will scatter over the tree and washing with an arsenical wash must be resorted to.

Codling Moth.-In some localities the larva of this moth does considerable damage to the apple crop. The egg is laid in early summer on the small fruitlet, on hatching out the larva makes its first meal off the eye of the apple, and then burrows in, tunnelling round the core. When full fed it leaves the apple and either crawls down the trunk in search of $a$ piece of rough bark or lets itself down by a thread from the apple to reascend the tree in search of a suitable place to spin up. This takes place in May. In order to help them in their search tie a piece of sacking round the trunk of the tree. They will spin up under this, and may be destroyed in the winter. Should this not have been done an arsenical wash should be used. Drops of spray will collect on the eye of the apple, and thus the first meal of the caterpillar will be poisoned. Poultry and pigs do much good in orchards by checking this pest.

The Appie Brossom Weevil.-There has been a considerable increase and consequently a considerable amount of damage done by this beetle of late. As soon as the flower bud begins to show colour the female comes out from her winter quarters and bores through the petals of the bud and deposits a single egg. The egg soon hatches into a yellowish footless grub, which at once com- 
inences to feed on the inside of the bud with the result that the future petals wither up and form a brown cap over the larva. The larvafeeds, grows andeventually pupates within this "capped" blossom. The weevil eats its way out, and early in September, crawls down the trunk of the tree seeking out any rongh bark under which to pass the winter. Failing this the weevil passes on and enters into the ground. As yet no very satisfactory method has been found for fighting this pest. As far as possible all capped blossoms should be destroyed. The trees should be jarred over a rick cloth, and the beetles which fall can then be destroyed. Grease bands placed on the tree in spring and again in early September will account for a great many. Poultry will devour many hundreds of these beetles if allowed to roam through the orchards. Weather governs the severity of the attack to a large extent. If the buds are checked by cold winds and nights the female is able to lay the full complement of eggs (about 50). If, on the other hand, the weather is warm the buds develop quickly, and the blossom opens before she has time to get rid of the full complement. She does not deposit her eggs in the opened flowers. Freshly planted stock and grafts are often seriously damaged by the

RED LEGGrD WLEVIL. -This beetle, half an inch in length, black in colour, with dark red legs, is nocturnal in habit. By day it hides under clods of earth at the foot of the tree, but directly it gets dusk it makes its way up to the tips of the branches and gnaws away the bark often rloing considerable damage.

Sacking placed round the base of the tree will trap the beetles, and they may then be destroyed by day. Napthaline sprinkled on the ground within a couple of feet radius will keep them away. This weevil is most numerous in chalhy districts.

Apple Sanfly Maggot is often a very serious pest to apples, it is advisable to hand pick damaged fruit, but otherwise no remedy has yet been found for it.

CAPSID BUGs damage apples and spoil their appearance, but for these also a complete remedy has not been found.

\section{PEARS.}

The pear is visited by many of the auple pests. There are, however, a few peculiar to the pear, the worst of which probably is the

Pear Mrdge.-This minute black creature, which measures about one-tenth inch in length, hatches out as soon as the buds begin to show white petals. The female punctures the buds with her long ovipositer, and deposits usually ten to a dozen eggs on the anthers. If the blossom is open the eggs are placed in the ovary. These eggs hatch in about ten days, the young maggots living in the small developing fruitlet. These attacked fruitlets grow away quickly becoming deformed. About the first week in June the maggots leave the pear, skip to the ground and there remais till the following spring. Although a most difficult creature to deal with, a great amount of good can be done by destroying all deformed and decaving pears in the spring. A dressing of Kainit under the trees about the time the larvae leave the fruitlets will lessen the attack next year. Undoubtedly the best method of keeping this creature in check is to stock the ground under the trees with poultry about the time the larvae are falling, and again when the fly is due to come out. Another pear pest that is greatly on the increase is the

Pear Leaf Blister Mrte.-This creature is nearly related to the Big Bud Mite of the currant, but works in a somewhat different way. Having passed the winter in the buds they make their way out directly the young leaves appear. They soon burrow into the leaf, causing a small red spot to appear. Each of these galls contains one female which lays about half-a-dozen eggs in each gall. As they hatch the young wander out over the leaves and then commence to make shelters for themselves. In the case of a bad attack the leaves become rolled up longitudinally. At times the galls are formed on the young fruitlets which usually die. Directly the leaves begin to die the mites make their way back into the buds, and there pass the winter. All varieties of pears seem to be attacked, and wall fruit is apparently the most susceptible. If the attack is not bad the leaves should be 
APPLE BLOSSOM WEEVIL.
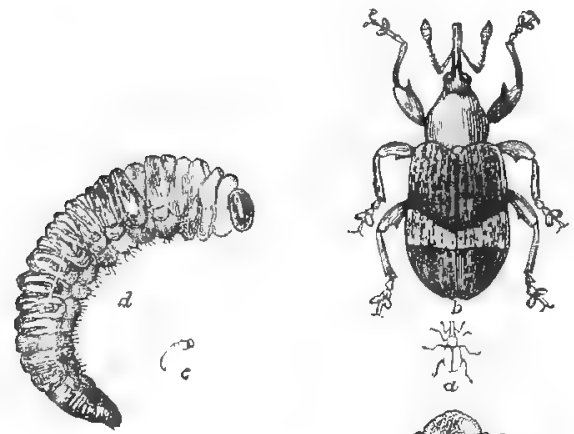

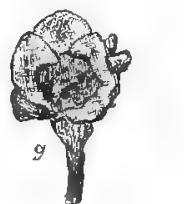

a. Weevil, natural size; $b$. Weevil, much magnified; c. Larva, natural size; $d$. Larva, much magnified; e. Pupa, natural size; f. Prapa, much magnifier; $g$ shows a Larva in a blossom bud.

\section{GOOSTBERRY LEAF SHOWING SAWFLY EGGS.}

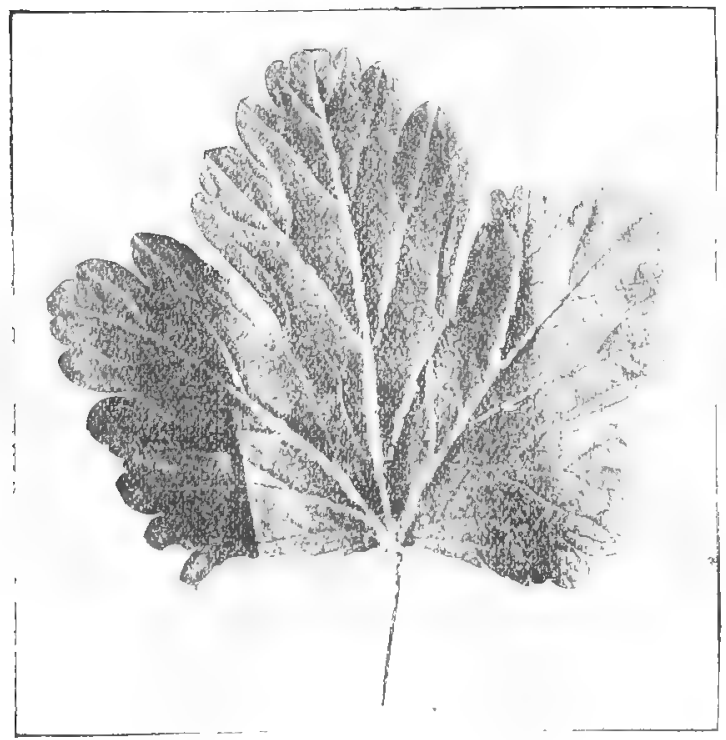

Some 60 eggs of Gooseberry Sawfly on underside of Gooseberry Leaf.
BIG BUD OR BLACR CURRANT GALL MITE.

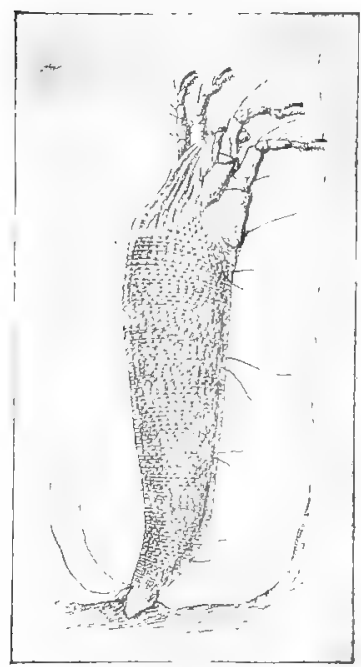

Mite ready to catch hold of a passing object, or to jump.
GOOSEBERRY SAWFLY.

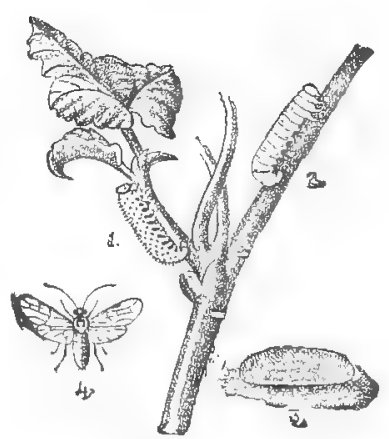

1. and 2. Larva in last stages of growth. 3 . Cocoon. 4. The saw. fly (or perfect insect). 
APPLE PSYLLA OT SUOKER.

PEAR LEAF BLISTER MITE.

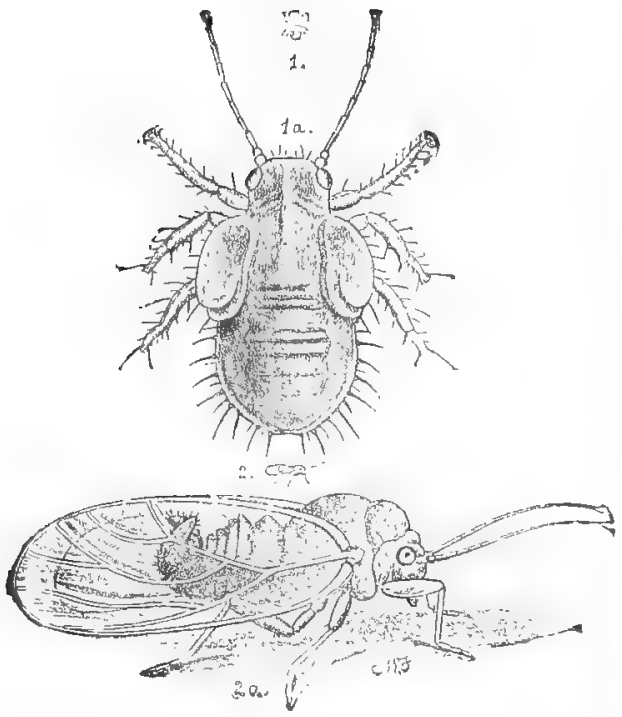

1 Larva, natural size. 1A. Larva after third moult, much magnified. 2. Perfect insect, natural size. 2A. Perfect insect much magnified.

\section{PEAR AND CHERRY SAWFLY.}

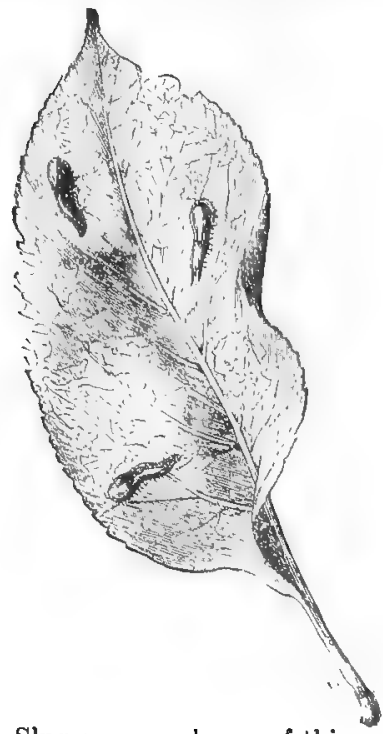

Slugworms or !arvæ of this sawfly on pear leaf.

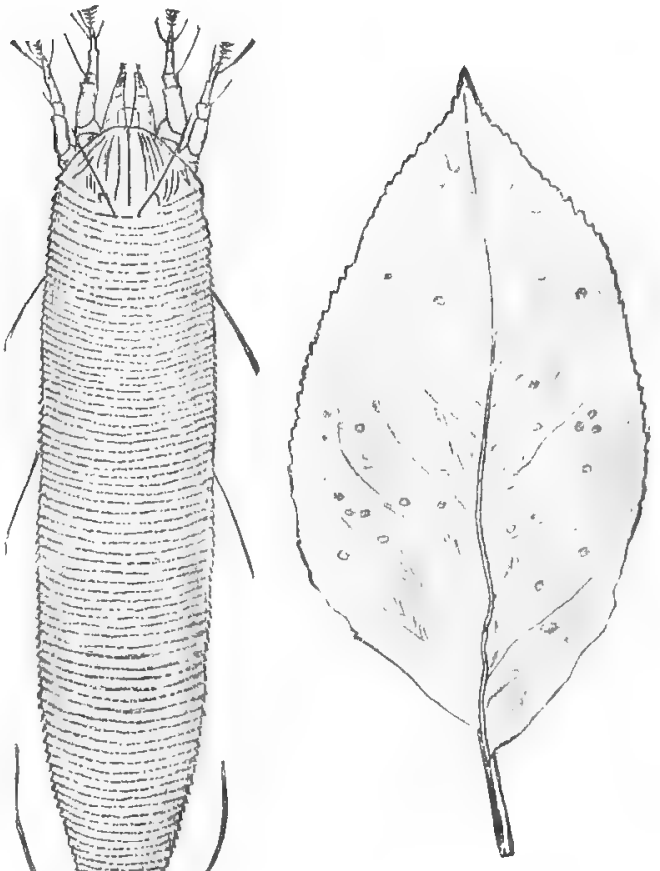

1. Mite greatly magnified. 2. Pear leaf, showing blisters caused by the Mites.

\section{PEAR MIDGE.}
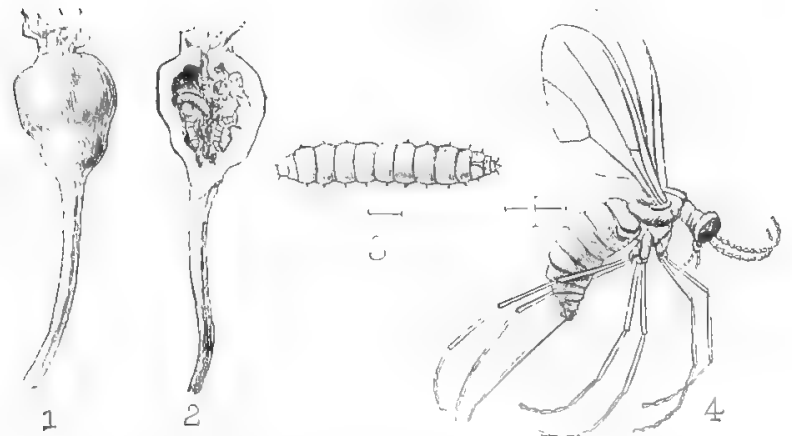

L. Stunted malformed pear causgd by l'ear Midge Iarvæ 2. Secticn of pear with larve inside. 3. Lan va magnified 4 Female fly, magnified. Lines show natural size. 


\section{WOOLLY APHIS.}

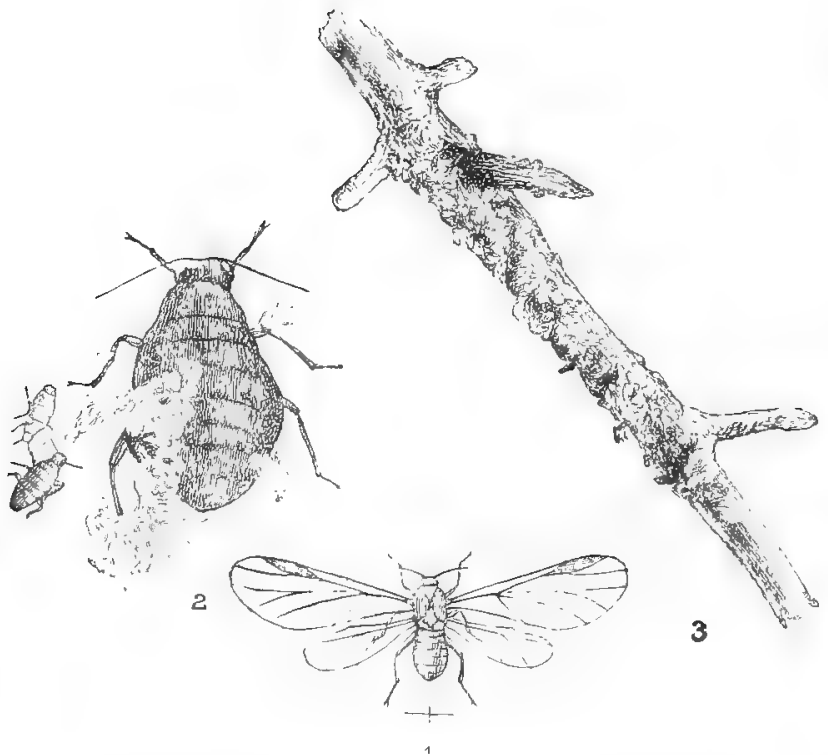

1. Winged female, magnified; and line showing natural size. 2. Wingless viviparous female, magnified. 3. Apple twig, covered by Woolly Aphides.
MOTTLED UMBER MOTH.

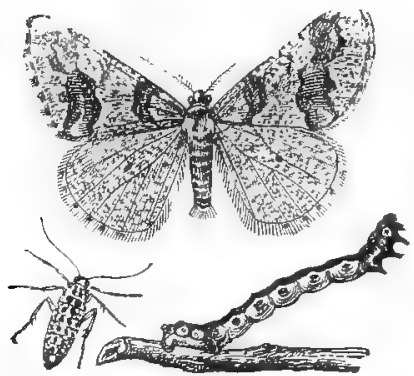

Male, winged; female wingless.

"Looper" or "Measurer" Caterpillar.

WINTER MOTH.

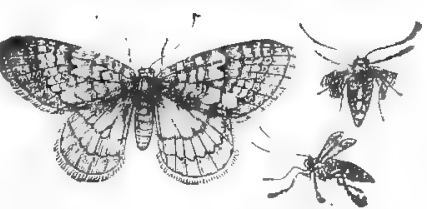

Winged male. Females with diminutive wings

\section{CODLIN MOTH.}

(1)
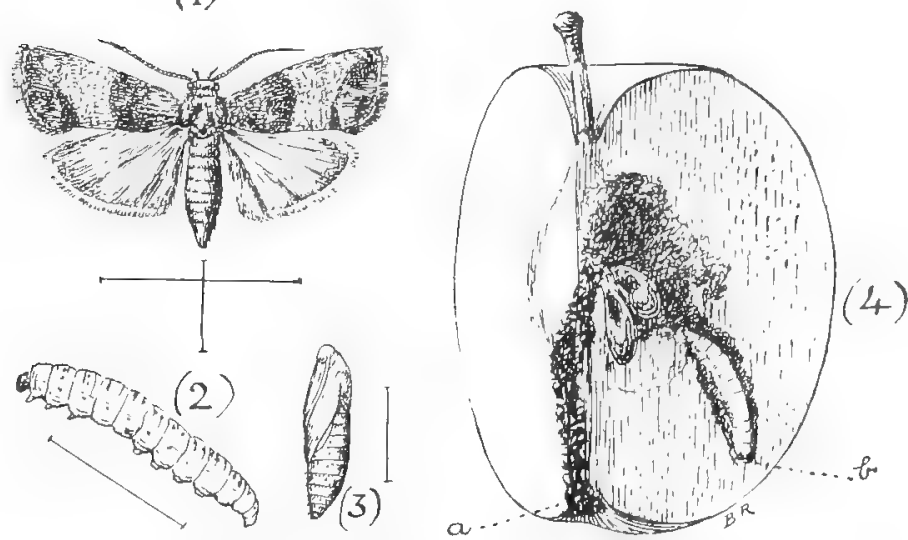

1. Codlin Moth, enlarged. Linc: show natural size.

2. Larva of codlin moth. 3. Pura c, codlin moth.

4. Section of an apple, larva baviug en tered at eye
(a) burrowed to core;
(b) leaving at side. 


\section{WOOLLY APHIS INJURY.}

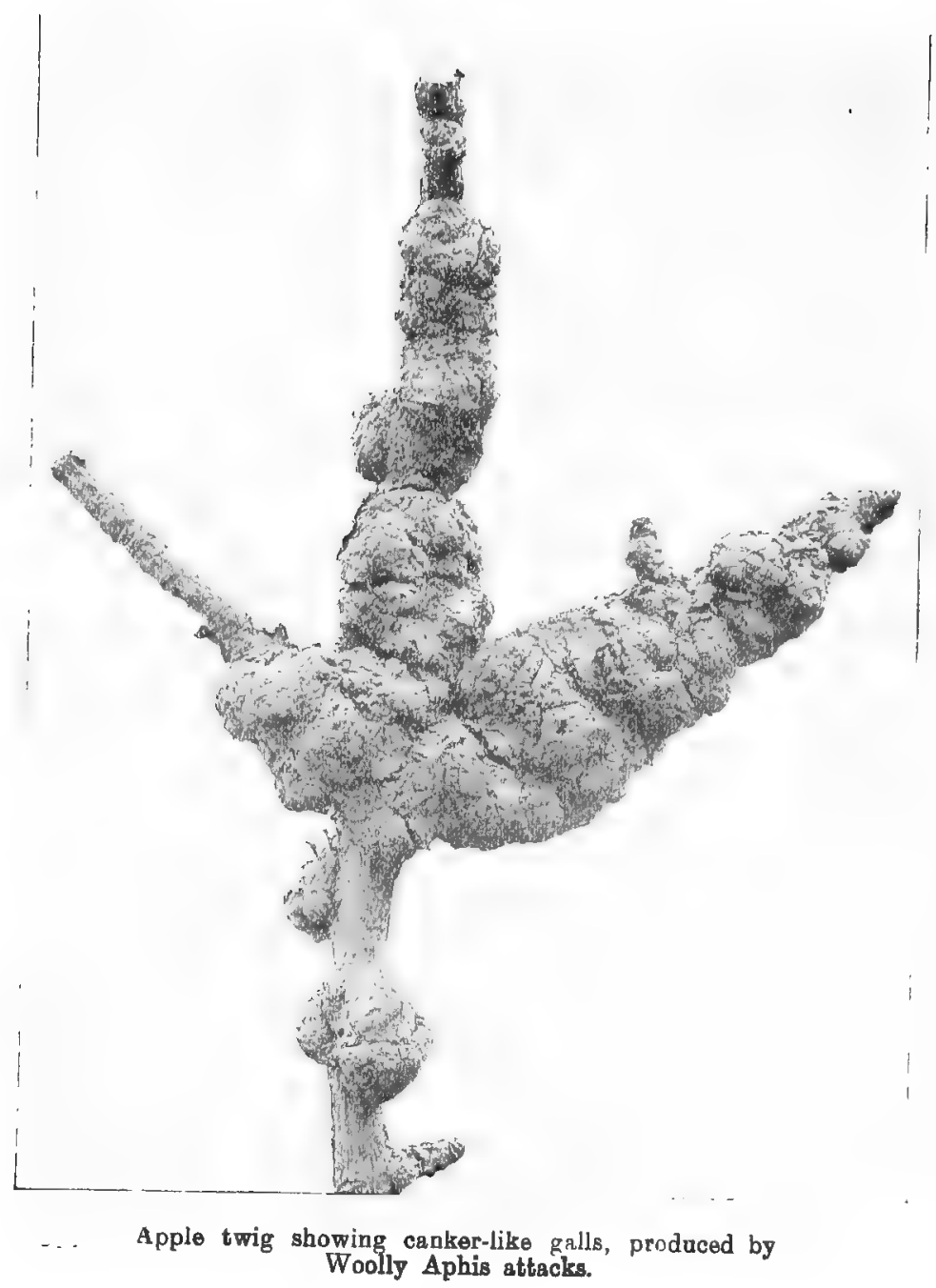


picked and burnt as soon as the small red blisters appear; otherwise a lime-sulphur caustic wash should be applied in the late autumn, and again in the spring. Very often in the late summer the leaves turn brown, and on examining one, it will be found that the upper green tissue has been eaten away. This has been caused by the caterpillar of the

Pear and Cherry Sawfly.-These sluglike grubs are dark olive green in colour and slimy, hence their popular name "slug-worm." When full grown they fall to the ground, pupate, and hatch.in about a fortnight. This second brood, which is usually by far the worst, lays its eggs on the leaves, and the larvae on hatching rapidly grow up and after becoming fullgrown drop to the ground and pass the winter in the soil. Arsenate of lead should be used in the autumn after the fruit is gathered.

\section{Plums.}

By far the commonest and worst enemies of the plums are the APHIDESAphis pruni, the Plum Aphis, and the Mealy Plum Aphis, Hyalopterus pruni. A soft soap and quassia wash is usually quite sufficient for aphides, but if the species is one which secretes a mealy substance a wash made up of 1 lb. Liver of Sulphur to 100 gallons paraffin emulsion will be found most reliable. Perhaps the most certain aphicide is nicotine, and this should be used before the creature has time to protect itself under a curled leaf.

\section{Gooseberries,}

We will now turn to the soft fruits. The worst enemy of the gooseberry in most parts is the

Gooseberry Sawhly.-The larvæ often do considerable damage by completely defoliating the bushes. The damage is typical sawfly damage, only the ribs of the leaves being left. The eggs are laid in the early summer in little groups always along the ribs. The larvae, on hatching, remain for a time on the same leaf, eating small holes along the ribs. As they grow they spread over the twigs. When fully grown they pupate in the soil; a second generation appearing in late summer. The larvae of this brood pass the winter in a cocoon in the soil. Any leaves containing eggs should be picked off and destroyed. The small holes should be looked for along the ribs. The colony may then be destroyed. The most reliable wash is arsenate of lead, but as this is more poisonous than Hellebore the latter is usually used instead. Hellebore powder loz. in 2 gallons of soft water in which a small quantity of soft soap has been dissolved. Do not pick the fruit for a month atter spraying for fear of the poison.

RED SPIDER often does considerable damage to gooseberries. By constantly sucking the sap they cause the leaves to become mottled and at times quite bleached. In specially bad attacks the leaves are deformed presenting a bunched appearance. The flowers are also attacked. As the spider hibernates under the bark a washing in late February with a strong paraffin emulsion may be resorted to with success.

\section{Black Currant.}

By far the commonest pest of the black currant is the creature known as the

BIG BUD MITE.-This mite works its way into the bud, gives rise to fresh generations and, they, by their constant sapping of the juices, start up an irritation which causes the bud to swell abnormally. The mite is to be found under cover all the winter. As spring approaches it leaves its shelter and either skips, crawls, or is carried by bees and birds or the clothing of the pickers to other branches. Here it seeks out a new bud and eats its way in. Nothing has been found up to the present to completely keep this pest in check, but whatever is used, it must be borne in mind that the creature is quite protected during the winter. Sulphur sprirkled on the trees during April, May and June has had good results, also a mixture of lime and sulphur. In both cases the dustings should be done when the bushes are wet.

\section{RASPBERRY.}

The Raspberry Beetle, a small brown beetle, is the greatest enemy the raspberry has. The beetle itself often does considerable damage to the buds and flowers; but the most harm is done in the larval stage. The eggs are laid in the blossom, and the young larvae attack the developing fruitlet. When full grown they fall. 
to the ground to pupate. The beetle is sluggish on dull days, and may then be jarred off the canes on to tarred boards. Arsenate of lead might be tried when the beetle is seen on the buds and blossoms.

\section{INSECTICIDES.}

Spraying for insects may be divided up into three classes:-

1. Winter Washes-for the destruction of scale, and cleaning trees of moss, lichen and rough bark, all three of which provide shelter for insects, pupae, and hibernating larvae.

2. Poison Washes-for destroying biting mouthed insects such as caterpillars and beetles.

3. Contact Washes-for the destruction of all Haustellate insects, i.e., insects with sucking mouths such is Aphides.

\section{Winter Washing.}

Certainly not necessary every year so far as insects are concerned. In the case of a large plantation it is best to divide it up into four areas and spray one portion each year, taking them in rotation. Winter washing is best applied in February or March, but it must not be left 200 late.

Two excellent washes are as follows:-

(1) Caustic soda (98 per cent. purity) .................. 2 lbs.

Water ...................... 10 gallons.

(2) Perhaps an even better wash made up with the following:-
Quicklime
Salt
$1 \mathrm{cwt}$.
Waterglass
$30 \mathrm{lbs}$.
Water
5 lbs. 100 gallons.

Slake the lime in half the water, dissolve the salt and waterglass in the other half. Strain off the lime wash and mix the two.

Poison or Summer Wash.

Arsenate of soda-pure crystallised

Acetate of lead ........... $7 \mathrm{oz}$.

Water

If dry commercial arsenate of soda is purchased, use only $2 \mathrm{oz}$. to $7 \mathrm{oz}$. acetate of lead.

Great care must be taken in mixing this wash lest scorching takes place. It must always be used as a fine spray; and it must be remembered that wash is poisonous to both man and animals and reasonable care must be taken. Stop spraying fruit four weeks before it is to be picked. Growers generally purchase this mixture as ready-made arsenate of lead paste, which saves the work of mixing.

\section{Contact Wasties.}

1. As nicotine paralyses rather than poisons it is placed under this heading. It is the most effective for aphides, psylla, and young caterpillar, but does not harm a large caterpillar. It is quite harmless to the trees, even when in full bloom; moreover, it does not interfere with the working of bees.

Nicotine (98 per cent.) 1 oz.

Soft Soap …............. 2 oz.

Water .................... 10 gallons.

2. Paraffin Jelly :-
Paraffin
5 gaslons.
Soft Soap
$8 \mathrm{lbs}$.
Water

1 pint.

Boil in a closed copper and add one pint of cold water. Pour off into a barrel and let cool. Use 10lbs. of jelly so formed in 40 gallons water.
3. Soft soap $1 \mathrm{lb}$.
Quassi $1 \mathrm{lb}$. Water ................... 10 gallons.

Soak the Quassia in water for a day, dissolve the soap in the rernainder, and mix the two. This wash is particularly useful where "honeydew," the secretion from aphides is bad.

Forty gallon disused paraffin casks are found very suitable for making-up spraying mixtures.

\section{Spraying Calendar.}

By C. A. W. Duffield, F.E.S.

Jan.-March.-Apply winter wash, once in three or four years. Caustic wash on gooseberries for scale. Paraffin or Sulphur for red spider.

Jan.-Feb.-Lime and salt to prevent hatching of plum aphis, and to keep birds from buds.

Feb.-April.-Lime and salt for sucker on apple.

April.-Just before apple buds burst spray with arsenate of lead. Also spray rasp- 
berries with arsenate of lead for beetle. End of month spray apples and plums with nicotine or paraffin jelly for aphides.

May.-Spray apples with arsenate of lead just after blossom has fallen for codling and winter moths. Plum and damsons with paraffin jelly using potass-sulphide if mealy plum aphis is present. Gooseberries and currants with hellebore for sawflies and magpie moth.

June.-Possibly cherries and currants for aphides. Straw band for codling moth larvae. May have to spray cherries, pear and plum for slug worm. Trap strawberry beetles by placing meal in sweetened water in a bowl at ground level. Spray nuts with arsenate of lead. Sept.-Spray for gooseberry sawfly and currant moth.

Oct.-Grease band first week for winter moth. Destroy leaves, shrivelled fruit, prunings, etc. Inject carbon bisulphide round roots of apple for woolly aphis.

The illustrations in this article are published by permission of the Ministry of Agriculture and HI.M. Stationery Office. The illustration, figure 2 , of Woolly Aphis, is from Mr. G. B. Buckton's "British Aphides," printed with permission of the Ray Society. 


\section{CHAPTER YXYV.}

\section{LIFE HISTORIES OF SOME WELL-KNOWN APPLES.}

With other information, gleaned from Hogg's Fruit Manual, Herefordshire Pomona, Apples of New York (1905), Messrs. Bunyard's Fruit Catalogue (1919), Order of Blossoming of Apples, by Mr. F. Chittenden, Journal of Royal Horticultural Society, Vol. 37 (1911-12), pps. 350361, Pollination Trials on Apples, R.H.S. Journal, Vol. 39 (1914), pps. 615-628; Report of John Innes, Horticultural Institute, in Journal of Pomology, Vol. I, No. 1 (1920), and Pollination of Fruits, by C. H. Hooper, in Journal of Ministry of Agriculture, May, 1921.

Apples recommended as the best for market growers, by Messrs. C. S. Smith and Mr. W. Miskin, from experience in Kent. For dessert:-Worcester Pearmain, Allington Pippin, Beauty of Bath, Gladstone, James Grieve. For Cooking: -Bramley's Seedling, Newton Wonder, Lord Derby, Grenadier, Stirling Castle; next to these: Baumann's Red Winter Reinette. Duchess Favourite (or Duchess of Gloucester), King of the Pippins, Lane's Prince Albert, Early Victoria, Norfolk Beauty and Rival.

Varieties suitable to grow as cordons for market growth, Mr. W. P. Seabrook, from his experience in Essex, recommends as most reliable:-Stirling Castle, Lord Derby, Lane's Prince Albert, James Grieve, Allington Pippin, and Cox's Orange Pippin, which is the best of all if environment suits it, but this must be ascertained.

List of Apples in Approximate Order of FLOWERING.

\section{Early Flowering.}

Duchess of Oldenburgh,-A Russian apple introduced into England in 1824. Fruit, cooking and dessert. Aug.-Sept. Occasionally self-fruitful.

IRISH PEACH.- Introduced from Ireland early in last century. Fruit, dessert, Aug. Self-fertile.

Tower of Glamis.-Peculiar to the orchards of Clydesdale and the Carse of Gowrie. Fruit, cooking. Nov. to Feb. Slightly self-fertile.

GOLDEN SPIRE.-Probably from Lancashire, where much grown about 1820. Fruit, cooking, Sept.-Oct. Self-fertile.
White Transparent.-Introduced from Russia early in 19th century. Is the Yellow Transparent of America. Fruit, dessert or cooking, July-Aug. Self-fertile.

BRADDICK's NoNPAREIL.-Raised by Mr. John Braddick, of Thames Ditton. Fruit, dessert. Nov. to April. Self-sterile.

KeswiCK Codlin.-Found at Gleaston Castle, near Ulverstone. Introduced by Mr. John Sander, a nurseryman, at Keswick, before 1813. Fruit, cooking. End June, Aug.-Sept. Somewhat self-fertile.

EgReMroNt Russer. - Fruit, dessert, Oct.-Nov. Self-fertile.

Brow nlees' Russet.--Introduced by Mr. William Brownlees, a nurseryman, at Hemel Hempsted, Herts., about 1848. Fruit, cooking, or dessert. Jan. to May. Self-sterile.

Stirling Castle.--Raised at Stirling, by Mr. John Christie, about 1830 . Fruit, cooking, Sept.-Oct. Sometimes selffruitful.

Devonshire Quarrenden.-Very old English variety. Fruit, dessert. August. Somewhat self-fruitful.

LORD SUFFIELD.-Raised by a hand-loom weaver, Thomas Thorp, at Middleton, near Manchester. Introduced to commerce about 1836. Lord Suffield being Lord of the Manor of Middleton. Fruit, cooking. Aug.-Sept. Self-sterile.

Christmas Pearmain.-Raised by $\mathrm{Mr}$. Manser, introduced by Messrs. Bunyard, in 1895. Fruit, dessert. Dec. to Jan. Self-fertile.

WASHINGTON.-Raised in Washington County, U.S.A., introduced by Messrs. Rivers, about 1812 . Fruit, Oct. to Dec. Somewhat self-fruitful. 
Bismarck.-Originated in the Province of Canterbury, New Zealand, about 1879. Fruit, cooking. Nov.-to Feb. Occasionally self-fertile.

Ribston Pippin.--Raised from pips from Rouen, by Mr. Lowe, gardener at Ribston Hall, Knaresborough, Yorkshire, about 1688, introduced about 1785 . Fruit, dessert. Nov. to Jan. Slightly self-fertile.

WARNER's KING.-Considered to have been grown since 1800, found at Weavering, in Kent, named Warner's King by Mr. Rivers, of Sawbridgeworth, who some years before received it from Mr. Warner, a small nurseryman, of Gosforth, near Leeds. Grows more healthily in Gloucestershire than in Kent. Fruit, cooking. Nov. Somewhat self-fertile.

Ben's ReD.-Raised near Penzance, about 1830 , by Mr. Benjamin Roberts, introduced in 1890, by Messrs. Bunyard. Fruit, dessert. Sept. Self-fertile.

MrlleR's Segdling.--Raised by Mr. W. Miller, a nurseryman at Speen, near Newbury, in 1848. Fruit, dessert. Aug. Very self-fertile. (The most self-fertile apple C.H.H. has found),

Baumann's Red Winter Reinette.Raised and introduced by MM. Baumann, of Bolwyller, in Alsace, about 1810. Fruit, cooking or dessert. Somewhat self-fertile.

Norfolk BeaUt'y.-Raised by Mr. Allan, at Gunton Park, from Waltham Abbey, pollenated with Warner's King, introduced in 1902. Fruit, cooking. Oct. to Dec. Self-sterile.

STRIPED BEAUfin.-Found growing in the garden of Mr. William Crowe, at Lakenham, near Norwich, in 1794, introduced by Mr. George Lindley. Fruit, cooking, unrivalled for baking. Oct. to May. Apparently self-sterile.

Sturmer Pippin.-Raised by Mr. Dillistone, a nurseryman of Sturmer, Suffolk, from Ribston Pippin x pollen of Nonpareil, introduced about 1840. Extensively grown in Australia for export. Fruit, dessert. March to June. Sometimes self-fruitful.

DUCHESS'S FAVOURITE.-Raised about 1820, by Mr. Cree, nurseryman, at Addestone, named on account of the favour it received from the Duchess of York. Fruit, dessert. Nov. to Christmas. Selfsterile.

Yellow Ingestre.-Raised by Thomas Andrew Knight, of Wormsley Grange.
Herefordshire, about 1800, from seed of Orange Pippin $\mathbf{x}$ pollen of Old Golden Pippin. Fruit, dessert. Sep. and Oct. Perhaps occasionally self-fertile. This, and the Red Ingestrie, were the produce of two pips taken from the same cell of an apple.

Claygate Pearmain. - Found in a hedge at Claygate, Surrey, introduced by Mr. William Braddick, about 1822 . Fruit, dessert. Dec. to Feb. Self-sterile.

\section{Mid Flowering}

Lord Grosvenor. - Fruit, cooking. Aug.-Sept. Somewhat self-fertile.

Cox's Orange Piprin.-Said to have originated in 1830, from seed of Ribston, was raised by $\mathrm{Mr}$. Cox, a retired brewer, at Colnbrook Lawn, near Slough, Bucks, introduced by Mr. Charles Turner, about 1850. Fruit, dessert. Nov. to Jan. Practically self-sterile. Mr. Cox also raised Cox's Pomona.

Charles Ross.-Raised by Charles Ross. Introduced 1899. Fruit, Oct.-Nov. Somewhat self-fertile.

EARLY VICTORIA, or Emneth Early.Introduced by Messrs. Cross, of Wisbech, in 1899. Fruit, cooking. July-Aug. Sometimes self-fertile.

Farly Julian.-An old variety, perhaps of Scotch origin. Fruit, dessert or cooking. 2nd week August.

BeaUty of Bath.-Raised at Bailbrook, introduced by Messrs. Cooling, of Bath, about 1865. Fruit, dessert, early Aug. Self-sterile.

Allington Pippin. - Introduced by Messrs. Bunyard, of Maidstone, in 1896. Fruit, dessert. Oct. to Dec. Slightly self-fertile.

CeLLINI.-Originated by $\mathrm{Mr}$. Leonard Phillips, of Vauxhall. Fruit, cooking. Oct.-Nov. Self-fertile.

Worcester Pearmain.-A seedling of Devonshire Quarrenden, raised near Worcester, introduced by Messrs. Richard Smith and Co., of Worcester, about 1873. Fruit, dessert. Sept. Sometimes selffruitful.

MaY Queen.--Raised by Mr. W. Crump, V.M.H., Madresield, Malvern, introduced by Mr. Penwill. Fruit, dessert. Jan. to May. Apparently self-sterile.

Ecklinville Seedling, raised at Ecklinville, near Belfast, Ireland, by Mr. 
Logan. about 1820. Grown largely in North Ireland, and Southern Scotland. Fruit, cooking. Aug.-Sept. Occasionally self-fertile.

LORD DERBY, raised by Mr. Witham, a nurseryman, near Stockport, about 1850. Fruit, cooking. Nov.-Dec. Self-fertile.

JAMES GRIEve, raised by $\mathrm{Mr}$. James Grieve, introduced by Messrs. Dickson, of Edinburgh, about 1890. Fruit, dessert. Sept.-Oct. Self-sterile.

Langley Pippin, raised by Messrs. Veitch, from Gladstone x Cox's Orange, introduced in 1893 . Fruit, dessert. Aug. Apparently self-sterile.

BRamley's SeEdling, raised by Mr. Bramley, of Southwell, introduced by Messrs. Merryweather, of Southwell, Nottinghamshire, in 1876. Fruit, cooking. Nov, to March. Occasionally, but rarely, self-fertile; more tender to frost than most apples in 1921.

The QueEN, raised by a cottager, near Chelmsford, in 1858, introduced by $\mathrm{Mr}$. Saltmarsh, in 1880 . Fruit, cooking. Oct. to Dec. Apparently self-steriu.

Rival, raised by Mr. Charles Rose introduced by Messrs. Clibrans. Fruit, cooking or dessert. Oct. to Dec. Somewhat self-fertile.

King of the Pippins, Reines des Reinettes of France, known before 1800 in Bel. gium as Kronen Reinette, Wintergold Parmane, of Germany. Fruit, dessert. Oct. to Dec. Occasionally self-fertile.

Lady Sudeley, raised by $\mathrm{Mr}$. Jacob, of Petworth, introduced by Messrs. Bunyard, of Maidstone, in 1885 . Fruit, dessert. Aug.-Sept. Occasionally self-fruitful.

PEASGOOD's Nonsuch, raised by $\mathrm{Mr}$. Peasgood, of Stamford, introduced in 1872. Fruit, cooking. Oct.-Nov. Occasionally self-fertile.

CRIMSON BRAMLer, a recent sport from Bramley's Seedling, similar. Somewhat self-fertile.

\section{Late Flowering.}

Blenherm Orange Pippin, raised about 1750 , by George Kempster, a tailor of Woodstock, near Blenheim. Fruit, cooking or dessert. Nov. to Feb. Self-sterile.

Lane's Prince Albert.-Found in a garden, at Berkhampstead, introduced by Messrs. H. Lane and Sons, in 1857. Fruit, cooking. Nov. to March. Long in flower.
Self-sterile, appears never to attempt to form fruit with its own pollen.

Grenadien.-Origin undiscovered, recorded in 1860. Fruit, cooking. Sept,Oct. Self-sterile.

Foster's Sfedling. - A seedling of Cellini. Fruit, cooking. Nov.-Dec. Apparently self-sterile.

Potr's Seedling.-Raised by Mr. Potts, in 1849, at Ashton-under-Lyne. Fruit, cooking. Sept.-Oct. Rarely self-fertile.

WELLINGTON, raised probably about 1750, by Mr. Dumeller (pronounced Dumelow), a farmer, at Shakerstone, Leicestershire, introduced by Mr. Richard Williams, of Turnham Green Nursery, about 1800. Fruit, cooking, till March. Apparently self-sterile.

Rambour-Papelin.-Raised by Messrs. Hartwiss, of Nikita, Crimea, before 1860, and named after M. Papelin, of Ghent. Fruit, cooking or dessert. March. Slightly self-fertile.

Gladstone.-Found in a field, by Mr. Jackson, a nurseryman, of Kidderminster, Worcestershire, and put into commerce in 1868. Fruit, dessert. July-Aug. Occasionally, but rarely self-fertile.

Golden Noble.-Introduced about 1820. Fruit, cooking. Oct.- to Dec. Sometimes self-fertile.

Annie Elizabeth. - Raised by $\mathrm{Mr}$. Greatorex, about 1857, introduced by Messrs. Harrison, of Leicester, in 1868. Fruit, cooking, till April. Occasionally, but rarely, self-fruitful.

Thomas Rivers.-Slightly self-fertile.

LORD BURGHLEX.-Raised in garden of the Marquis of Exeter, at Burghley, near Stamford, introduced by Messrs. House, nurserymen, at Peterborough, in 1865. Fruit, dessert. Feb.-March. Self-fertile.

Mrs. Phillimore. - Raised by Mr. Chas. Ross (Lord Burghley x Gladstone), introduced by Messrs. Bunyard, in 1900. Fruit, dessert. Nov. to March. Apparently self-sterile.

Newton WoNDer.-Raised in Nottinghamshire, introduced by Messrs. Pearson about 1887. Fruit, cooking. Dec. to May. Occasionally self-fruitful.

Williams' RED Fayourite.-Originated in Roxbury, Mass, U.S.A., more than 165 years ago. Fruit, late Aug. and Sept. Self-sterile. 
Red Joaneting.-One of our oldest apples, mentioned by Rea, in 1665 . Fruit, dessert. Ripe by Aug. 29, John the Baptist's Day. Self-sterile.

American Mother.-Known in America before 1848, introduced by Messrs. Rivers. Fruit, dessert. Nov. Apparently selfsterile.

KING EDWARD VII.-Raised by Messis. Rowe, of Worcester, and sent out about 1908. Fruit, cooking. Jan. to April. Probably self-fertile, as it sets many fruits with own pollen, but all fell before mature in trials at Wye, in 1920.

Royal Jubilek.-Raised by Mr. John Graham, near Hounslow, introduced by Messrs. Bunyard, in 1893. Fruit, cooking. Oct.-Dec. Apparently self-sterile.

RoMe Beauty.-Originated by $H$. N. Gillett, Lawrence County, Ohio, U.S.A., previous to 1848 . A great favourite in Australia. Fruit, Nov. to May. Apparently self-sterile.

Crawley Beauty.-Raised in a cottage garden, at Tilgate, near Crawley, Sussex, introduced by Messrs. Cheal. Fruit, March-April. Believed to be self-fertile. Flowers very late.

Court Pendu Plat.-Of great antiquity, dating certainly from 16th century, possibly from Roman days. Named from its short fruit stems. The latest to flower. Fruit, dessert. Dec. to March. Selfsterile.

\section{Order of Flowering not RECORded.}

BenonI.-Originated at Dedham, in Massachusetts, U.S.A., introduced by $\mathrm{Mr}$. Rivers, of Sawbridgeworth. Fruit, dessert. September. Apparently self-fertile.

Coronation. - Self-fruitful.

DUKE OF YORK.-Apparently self-sterile. Encone.-Raised by Mr. Charles Ross. (Warner's King $x$ Northern Greening), introduced 1908. Fruit, cooking, till March. Possibly self fertile.

Ellison's Orange.-Raised by the Rev. C. Ellison, introduced by Messrs. Pennell, of Lincoln. Possibly self-fertile.

Feltham Beauty.-Raised by Messrs. Vritch, in 1908 (Cox's Orange x Glad- stone). Fruit, dessert. Aug. Apparently self-sterile.

Hunt's Early.-Dessert. First week August. Possibly self-fertile.

JOHN DownIE CRAB.-Raised and sent out by Mr. Holmes, of Lichfield. Strongly self fertile, a good polleniser for other varieties of apple, including Cox's Orange.

KING's ACRE PIPPIN,-A cross between Ribston and Sturmer Pippin, introduced from Hereford in 1899. Fruit, dessert, Jan. to March. Possibly self-fertile.

RED VICTORIA.-Seedling recently found. at Wisbech, introduced by Mr. Miller, of Wisbech. Fruit, cooking. Aug. and Sept. Somewhat self-fertile.

Sir John ThORNYCROFt.--Raised by Mr. Callister, gardener to Sir John Thornycroft, Bembridge, Isle of Wight, introduced by Messrs. Bunyard, about 1911. Apparently self-sterile.

From the point of view of best crosspollination, avoid planting very early. flowering varieties with very late flowering sorts, plant, an early flowering sort with another early flowering, or midseason flowering sort, and late flowering with a late flowering, or mid-season flowering sort.

The "Journal of the Ministry of Agriculture," June, 1920, pp. 290 to 295, "Profitable Apples for Market" and Leaflet No. 134, give good descriptions of the fruit, habit of tree, whether of upright or spreading growth, quick or slow growth, liability to insect pest or disease, best soil and soils to avoid, whether the variety succeeds best as a bush or standard tree, stock best suited, mentioning varieties that fruit at tips of boughs, with nther useful information

NoтE.-Since writing the above, I have seen an orchard of considerable size of Bramley's Seedling in Kent, also of Lane's Prince Albert at Ledbury, Herefordshire, each planted with practically no other variety, yet each carrying a good crop. It seems possible that if a variety is in ideal surroundings and well cared for, it is more likely to be self-fruitful than where things are adverse. 


\section{CHAPTER XXXVI.}

\section{THE HISTORIES OF SOME OF OUR WELL-KNOWN PFARS.}

Compiled from various sources.

$[b$, blossom early, mid-season or late, taken from "Order of Flowering of Pears" at Wisley by F. Chittenden, Journal of the Royal Horticultural Society, Vol. 39 (1913), pp. 366-372. f, the month when the pear is ripe.]

Conference, raised by Messrs. Thomas Rivers and Sons, of Sawbridgeworth, Herts., introduced about 1894, somewhat self-fertile, said not to be attacked by pear midge. $b$, early; $f$, Oct.-Nov.

DOCTOR JULES GUYOT, raised by $\mathrm{Mr}$. Ernest Ballet, of Froyes, France, in 1870, occasionally self-fertile. $b$, late; $f$, early Sept.

Fertility, raised by Mr. Rivers from Beuryé Goubault, in 1875, said to be one of the most profitable market pears that can be grown. $b$, late: $f$, Oct.

DURONDEAU, raised in 1811, the original tree still existed in 1884, in the garden of the late M. Durondeau, at the village of Tongre-Notre-Dame, near Ath, in Belgium. Self-fertile. $b$, mid.; $f$, Oct.-Nov.

Clapp's Favourite, raised by Mr. Thaddeus Clapp, of Dorchester, Massachusetts. UT.S.A. Self-sterile. $b$, mid.; $f$, Aug.Sept.

Marguerite Marillat, raised by $M$. Marillat, at Villeurbaume, near Lyons, France, about 1874 . $b$, mid.; $f$, Sept.

Grosse Calebasse, a Belgium variety raised by $\operatorname{Van}$ Mons in 1820 . $b$, mid.; $f$, Oct.

Hessue, found at Hessle, in Yorkshire. Hardy. Self-fertile. $b$, late; $f$, Oct.

The above are recommended as some of the most reliable for market.

Autumn Bergamot is thought by one author to have been in England ever since the time that Julius Cæsar conquered it, and possibly was the Assyrian Pear of Virgil. Dr. Hogg, however, doubts this, as it is not mentioned as being cultivated in the London nurseries in 1688. It is, however, a good old dessert pear. $f$, Oct.
Beurre Bosc, considered to have been found in a wood near Apremont, France, as a wildling by Van Mons, who dedicated it to M. Bosc, the eminent Director of the Jardin des Plantes, at Paris, about 1835. Self-fertile in America. $b$, late; $f$, Oct.Nov.

BeURre Capiaumont, raised from seed by M. Capiaumont, a druggist, of Mons, in Belgium, in 1787. b, late; $f$, Oct.

BeUrre Clairgeau, raised by a gardener named Clairgeau, of Nantes, previous to 1848, distributed by $\mathbf{M}$. de Jonghe, of Brussels. $b$, mid.; $f$, Nov.

Beurre d'Amanlis, raised at Amanlis, near Rennes, in Brittany, about 1805. $b$, early.

Beurre Diel, discovered by M. Meuris, gardener to Dr. Van Mons, on a farm near Vilvorde, Belgium, about 1810. Van Mons dedicated it to his friend, Dr. Diel, the famous pomologist, of Dietz, in the Duchy of Nassau. Self-fertile in America. $b$, early ; $f$, Oct.-Nor.

BEURRE HARDY, raised by M. Bonnet, of Boulogne, the friend of Van Mons, first distributed by M. Jamin, of Bourg-laReine, near Paris, who dedicated it to the late M. Hardy, director of gardens of the Luxembourg, Paris. $b$, early; $f$, Oct.

BettrRe SUPERfin, raised at Angers by M. Goubault, in 1837. It first bore fruit in 1844. $b$, early; $f$, Oct.-Nov.

Black Pear of Worcester or Verulam, a very old variety, figuring in the arms of the City of Worcester, it is said that the Worcestershire bowmen wore this badge at the Battle of Agincourt, in 1445. $b$, early; $f$, Jan.-March.

CatillaC, a variety of great antiquity, known before 1665 , probably named after 
Cadillac, a small town near Bordeaux. in France. Cooker. b, late; $f$, Dec-April.

Charles Ernest, raised by Mr. Ernest Baltet, of Troyes, France, sent out in 1879. $b$, mid.; $f$, Nov.-Dec.

Colmar D'ETE, a seedling raised by Van Mons in 1820. b, mid. : $f$, early Sept.

Conseilleur a la Cour, raised by Van Mons, named in honour of his son, Councillor at the Court of Appeal, Brussels, it fruited in 1840 . is said to do well on chalk. $b$, early; $f$, Nov.

CRAWFORD, an early Scotch pear, grown over the whole extent of the country. $f$, mid. Aug.

Doyenne D'ETe (Gift of Summer), an early seedling of Van Mons, raised about 1800. Somewhat self-fertile. $b$, early; $f$, July.

DoYenNe DU COMICE, raised in the garden of the Comice Horticole at Angers, the original tree first fruited in 1849. Selfsterile. $b$, late; $f$, Nov.

Duchesse D'Angouleme, found by M. Anne-Pierre Andusson, nurseryman, in the garden of a farm near Campigne, in Anjou, France. Trees were first sold in 1812. In 1820 he sent a basket of the fruit to the Duchesse d'Angouleme, with a request to name the pear in honour of her, a request which was granted, and since that time it has borne its present appellation. Is somewhat self-fruitful. $b$, early; $f$, Oct.-Nov,

Easter Bergamot, a very old variety. Switzer mentions that trees of this variety were planted against a wall in Hampton Court Gardens in Queen Elizabeth's reign. $f$, March-April.

EASTER BEURRE, originated in the garden of the Monastry of the Capucins, at Louvain, Belgium, soon after 1800, and was first distributed by Dr. Van Mons. $b$, early; $f$, Jan,-March.

Emile D'Hexst, raised by Major Esperen, of Malines, Belgium. It first fruited in 1847, was named after Emile Berckmans, of Heyst-op-den-Berg, who afterwards emigrated to America and became a prominent pomologist in that country, $b$, mid.; $f$, Oct.-Nov.

Flemish Beauty, discovered by Dr. Van Mons in the Village of Deftinge, in Flanders in 1810 . He brought the variety into notice by distributing grafts among his friends. Self-fertile in America. $b$, mid.; $f$, Sept.

Fondante De Thirriot, raised by MM. Thirriot Frères, nurserymen, at Charleville, Ardennes, France. Found to be a good market pear at Pershore. $b$, mid.; $f$, Nov.-Dec.

Forelle or Trout Peir, an old German variety, some 200 years old, supposed by Dr. Diel to have originated in Northern Saxony. $b$, early; $f$, Nov.-Feb.

Gansel's Bergamot, said to have been raised from seed of Autumn Bergamot by Lieut.-General Gansel at his seat, Donneland Park, near Colchester. Self-sterile. $b$, late; $f$, Oct.-Nov.

General Todleben, raised by M. Fontaine de Gheling, of Mons, Belgium, in 1839, named after the gallant Russian defender of Sebastopol. Occasionally selffertile. $b$, late; $f$, Nov.-Dec.

Glou Morceau, raised by Abbé Nicolas Hardenport, at Mons, between 1730-60. He also raised Passe Colmar and Beurré Rance, probably by artificial cross fecundation. $b$, late; $f$, Dec.-Feb.

JARGoNelle, an old favourite, but it is not known when it was first introduced into this country. Brought from France. Believed to be one of the oldest pears; was in cultivation before 1600 . $b$, early; $f$, Aug.

Josephine De MaLines, raised by Major Esperen, of Malines, in 1830, and named in compliment to his wife. $b$, late; $f$, Jan.May.

LE LeCTIER, raised by M. Leseur at Orleans, France, named after the famous pomologist, who in 1628 was cultivating some 260 varieties of pears. $b$, late; $f$, Dec.-Jan.

Lourse Bonne, an old French Pear, originated in Poitou, on the property of a lady whose Christian name was Louise. $f$, Nov.-Dec.

LOUISE Bonne OF JERSEY, raised at Avranches about 1788 by M. Longueval. $b$, mid.; $f$, Oct.

Marie Louise, raised in 1809 , by Abbé Duquesne, of Mons, and named in honour of Marie Louise, the consort of Napoleon. Self-fertile. $b$, late; $f$, Oct.-Nov.

Olivier de Serres, raised by M. Boisbumel, of Rouen, about 1847, and named 
after "The Father of French Agriculture," M. Olivier de Serres. b, mid, $f$, Feb.-March.

Pitmaston Duchess, seedling, raised by Mr. Williams, of Pitmaston, near Worcester, obtained from Duchesse d'Angouleme with Glou Morceau pollen, about 1840 . Occasionally but rarely selffertile. $b$, one of latest; $f$, Oct.-Nov.

Princess, raised and introduced by Messrs. River's about 1886. b, early; $f$, Oct.-Nov,

Roosevert, introduced by Messrs. Baltet, of Troyes, in France, about 1906. b. early; $f$, Oct.

SECKLe, an American pear, first exhibited in London in 1819. $b$, mid.; $f$, Oct.Nov.

Souvenir DU Congres, said to be in good pear for market. $b$, mid, ; $f$, Sept.

THompson's, raised by Van Mons before 1820 , dedicated to the famous Fruit Superintendent of the Royal Horticultural Society, England. b, early; $f$, Oct.-Nov.

TRIOMPHE DE VIENRE, raised by M. J. Collaud, gardener at Montagnon, and introduced by M. Blanchet of Vienne, near Lyons, France. $b$, late; $f$, Sept.

URBANISTE was raised previous to 1786 , in the garden of a nunnery at Malines belonging to the Urbanistes. $f$, Oct.

Uvedale's St. Germain, raised by Dr. Uvedale, a schoolmaster at Eltham, in Kent, in 1690. b, mid.; $f$, Jan.-April.

VICAR OF WINRFIELD, found growing wild in a wood in 1760 , by M. Leroy, Curé of Villiers-en-Brenne, in the department of the Indre, France. Introduced into England by Rev. W. L. Rham, the Vicar of Winkfield, in Berkshire, hence the name. $f$, Dec.-Jan.

White Doyenne, a very old variety, a very favourite Pear in France and Germany. Self-fruitful in England and U.S.A. b, mid.; $f$, Sept.-Oct.

Williams' BoN CHRETIEN, raised a short time previous to 1770 by a schoolmaster at Aldermaston, in Berkshire, distributed by Mr. Williams, of the Turnham Green Nurseries, Middlesex, introduced into America in 1799 by M.r. Enoch Bartlett, of Dorchester, near Boston, hence called "Bartlett" in America. Occasionally selffertile, $b$, late; $f$, Sept.

WinTer Nelis, raised early in the last century by Mr. Jean Charles Nelis, of Malines, in Belgium, and introduced into this country by the Horticultural Society of London in 1818. Self-sterile. b, early; $f$, Nov.-Jan.

WINTER WINDSOR, a very old English variety, is recommended for regrafting pear trees found to be unprofitable.

The majority of Pears are absolutely self-sterile. Self-fertilized fruits have been obtained by $\mathrm{Mr}$. Fred Chittenden, Director of the Royal Horticultural Society's Gardens at Wisley, in the following varieties:-Passe Colmar, Jargonelle, Dr. Jules Guyot, Hacon's Incomparable, Marie Louise, White Doyenné, Verulam or Black Pear of Worcester, Hessle, Easter Beurré, Pitmaston Duchess (rarely), Williams Bon Chretien (rarely), Doyenné Boussoch, Beurré Bachelier.

The above information as to the histories of the different varieties of Pear, is gleaned chiefly from "The Herefordshire Pomona," by Dr. Bull (1880-1884); "The Fruit Manual," by Dr. Hogg (1884); and "Fruit Catalogue of Messrs. G. Bunyard and Co.," of Maidstone, Kent (1919). Edited by Mr. Edward A. Bunyard, F.L.S., a most interesting work as to the origin of fruits, price $6 \mathrm{~d}$ 


\section{CHAPTER XXXVII.}

\section{THE HISTORIES OF THE PLUMS WE GROW.}

Collected from various sources, chiefly from "The Fruit Manual," by Robert Hogg (1884); “The Plums of New York," by U. P. Hendrick; and Bunyard's "Fruit Catalogue " for 1919. Notes as to self-fertility ana self-sterility are based on trials at the John Innes Horticultural Institution at the Royal Horticultural Society's gardens and my own experiments.

An account of English plums should begin with the mention of $\mathrm{Mr}$. Thomas Rivers and his sons, at Sawbridgeworth, Herts, who have raised and introduced more valuable new plums than anyone else, even more than Mr. Luther Burbank, they include Rivers' Early Prolific or Early Rivers (about 1866); Early Transparent Gage (1866); Automne Compote, Blue Rock, Sultan (1871); Grand Duke (1876); Czar (1878); Archduke (1883); Monarch (1885); Stint (1885); Curlew, Bittern, Mallard, Heron (1888); Late Orange (1892); Late Transparent (about 1892); Golden Transparent Gage (1894); Primate (1897); Admiral, President (1901); Rivers' Late Green Gage; Rivers' Early Damson.

\section{Gage, Greengage or Raine Claude Plums.}

This group of plums being the most delicious of dessert plums, is mentioned first; many are, however, difficult to get to fruit unless in favourable environment. The greengage is supposed to be a native of Greece, and to have been introduced at an early period into Italy, where it is called Verdochia; from Italy it passed into France, during the reign of Francis I., about 1500 , and the fruit was named Reine Claude in honour of his queen. Francis I. met Henry VIII. at the "Field of the Cloth of Gold." This plum seems to have been introduced into England soon after, and is mentioned by Parkinson, in 1629, as Verdoch, at which time it does not seem to be rare or new. How did the name "gage" get applied to this class of plum? The story given is somewhat as follows:- Soon after $1700 \mathrm{Sir}$ Thomas Gage, of Hengrave Hall, near
Bury St. Edmunds, received a number of plum trees from his brother, Rev. John Gage, a Roman Catholic priest, then resident in Paris; one of these having lost its label, the gardener after the tree came into bearing called "Greengage," in honour of his master, as the fruit was green.

Greengage, or Old Greengage.-Known in France as Grosse Reine Claude, is said to be greatly improved by being grafted on the apricot (Hogg). Bullfinches attack buds of greengages specially. Selfsterile. Flowers early. D. early Sept.

Reine Claude de Bavay.-A seedling ot Reine Claude, raised by Major Esperen, of Malines, Belgium, about 1832, and dedicated to $M$. de Bavay, Director of the Royal Nurseries, at Vilvordes, near Brussels. Slightly self-fertile. D. end sept.

Early or July Greengage.-The Reine Claude de Bavay Hative of the French. Introduced from Normandy, by M. Davion half a century ago. Self-sterile.

Old Transparent Gage-Raised by $M$. Lafay, a nurseryman, near Paris, called by the French, Reine Claude Diaphanée, is slightly self-fertile. Ripe early Sept.

Oullins Golden Gage-the Reine Claude d'Oullins, or Reine Claude Précoce of the French, originated at Coligny, and was introduced to commerce by M. Massot, of Oullins, near Lyons, about 1860. Slightly self-fertile. Flowers late; ripe early Aug.

Bryanston Gage.-Raised at Bryanston Park (the seat of Lord Portman), near Blandford, Dorset, exhibited in 1831, said to be a cross between Old Greengage and Coe's Golden Drop. Self-sterile. D. midSept.

Comte d'Althan's Gage.-Raised at Swoyschitz, in Bohemia, by Prochastre, 
the gardener to Comte Michael Joseph d' Althan, introduced into England about 1869. Self-sterile. D. mid-Sept.

Purple Gage.-The Reine Claude V1olette of the French, probably raised by M. Galopin of Liège, Belgium. D. early Sept.

Coe's Golden Drop.-Raised about 1809 by Jervaise Coe, a market gardener, at Bury St. Edmunds, Suffolk, it grew from a greengage stone, probably fertilised by a White Magnum Bonum, which grew aside it. T. A. Knight sent a tree of this variety to America in 1823. Flowers late. D. end Sept. Self-sterile.

Denniston's Superb Gage.-Grown by Isaac Denniston, Albany, New York, about 1835 or $1840 . \quad$ Very self-fertile. Flowers mid-season. D. early Aug.

Jefferson Gage-Raised by Judge Buel, Albany, New York, U.S.A., about 1825, named in honour of President Jeffersou. Self-sterile. Flowers early. D. early Sept.

Washington Gage-Appears to have been raised about 1790 from a greengage stone in the nursery of William Prince, at Flushing, Long Island, U.S.A., and named after the famous president. Is selfsterile. D. early Sept.

\section{Prune Piums.}

Prune d'Agen Plum.-The great prunemaking plum of France and America, tradition says that on the return of the Benedictine. monks from the Crusades, this plum was brought from Turkey or Persia, where it was known as the Date Plum, it was planted in the Abbey garden, near Bordeaux. It is extensively grown in the Agen region of France, where it is dried. self-sterile. D. end Sept.

The Giant Prune.-Raised by Luther Burbank, Santa Rosa, California, from seed of Agen, fertilised by Pond, the Hungarian prune of the Pacific Coast. Slightly self-fertile. C. early Sept.

Italian Prune.-Originated in Italy, at least a century ago, has long been common in Northern Italy, especially around Milan. Beginning Sept.

Ickworth Imperatrice. - Raised by Thomas Andrew Knight, from Imperatrice fertilised by Golden Drop, named after Ickworth Park, near Bury St. Albans. Knight aimed in raising this and other plums to produce a fruit containing suffi- cient sugar to keep well and not shrivel. In Ickworth he succeeded to a high degree. Self-sterile. Ripe in Oct.

German Prune or Guetsche.-One of the oldest plums in cultivation; superseded by better varieties. C. end of Sept.

\section{Damsons (Oval).}

The common damson, the damson of the ancients, is adapted to various climates and soils. It takes its name from Damascus, in Syria, it was brought to Italy at least a century before the Christian era.

Farleigh, Crittenden, or Cluster Damson.-Raised by James Crittenden, of East Farleigh, in Kent, about 1800. Can be raised from suckers. Flowers late mid-season. Silightly self-fertils. Ripe mid-Sept.

Merryweather Damson.-Originated by H. Merryweather and Sons, Southwell, Notts., England. Exhibited in 1907. C'. ripe very late.

River's' Early Damson.-From seed of St. Etienne Plum. Ripens beginning of August.

The Shropshire or Prune Damson, known since 17 th century, the farourite of the West of England and Pershore district, blossoms late. Ripe mid-Sept.

\section{Bullace (Round).}

Black Bullace-the wild bullace found occasionally in woods. Ripened by the early frosts.

White Bullace-an old variety, mentioned by Parkinson, in 1629. An immense bearer. Self-fertile. Ripe end Oct. and beginning of Nor.

Langley's Black Bullace-raised by Messrs. Veitch, from Farleigh Damson $x$ Early Orleans, introduced in 1902. lipe Nor.

\section{Other Plums.}

Victoria.-Discovered in a garden at Alderton, in Sussex, and later sold as Denyer's Victoria, by Denyer, a nurseryman, at Brixton, near London, in 1844. Very self-fertile. Delicate to frost. Flowers mid-season. Ripe early Sept.

Pershore Egg Plum.-The Worcestershire plum, long grown at Pershore. Excellent green for cooking and preserving, yellow when ripe, then woolly. Comes from sucker. Is a good stock for 
other plums; is less liable to silver leaf than other plums. Is very self-fertile. Flowers mid-season. Ripe mid to end Aug

Pershore Purple or Martin's Purple (sometimes, but incorrectly, called Purple Egg) was raised in 1877 by Walte' Martin, a smallholder at Pershore, Worcestershire, from the Purple Gage pollinated with Rivers' Early Prolific pollen. The tree from which the fruit and stone was raised is still in Pershore. Is very self-fertile. Propagates by suckers or by grafting. Blossoms mid-season; ripe Aug.

Czar.-Raised by Mr. Thomas Rivers, of Sawbridgeworth, from Prince Englebert, fertilised by Early Prolific pollen, fruited first in 1874, the year the Emperor of Russia visited England. Very self-fertile. Blossoms mid-season. C. early Aug. Monarch-Raised by Thomas Rivers, from a seedling of Autumn Compôte: introduced to commerce in 1885 . Popular in England and America. Self-fertile. Flowers early. D. or C. end Sept. and Oct.

Rivers' Early Prolific or Early RiversRaised by Mr. Thomas, from Précoce de Tours, about 1834 . Only occasionally selffertile-say one flower in 100 . Flowers early. C'. end July.

Grand Duke.-Raised by Mr. Thomas Rivers from Autumn Compôte; sent out in 1876. Flowers very early; is late to ripen. The favourite late-shipping plum of New York. Self-sterile.

Bush.-A great favourite in Kent; found in a hedge at Bobin, near Sittingbourne, in 1836, and propagated by Mr. Fair. Self-fertile. Ripe mid-Oct.

Black Diamond,-Found in a hedge by a farm labourer, named Diamond, about 1830; propagated in the nursery of $\mathrm{Mr}$. Hooker, of Brenchley, Kent. Self-sterile. Blossoms early. Ripe early Sept.

Kirke's Blue.-Originated on Mr. Poupart's market garden, at Brompton, pro- pagated by Joseph Kirke, nurseryman, about 1830 . Repays root pruning. Selfsterile. Blossoms mid-season. D. midSept.

Pond's Seedling.-Obtained from seed by Mr. Pond, an amateur fruit-grower in England, before 1830. Called also Fonthill. Self-sterile. Blossoms late: ripe mid-Sept.

President.-Raised by Messrs. Rivers in 1901. Blossoms late. C. Oct. Partly self-fertile.

Early Orleans.-Of old, but unknown, origin; the Prune du roi of the French. Partly self-fertile. Blossoms mid-season; ript beginning and middle Aug.

Belle de Louvain.-Found in the nursery of Van Mons, at Louvain, in Belgium, about 1840. Slightly self-fertile. Blossoms late; blossom tender to frost. C. end Aug.

Stint.-Partly self-fertile.

Sultan.-Raised by Mr. Rivers in 1871, from Belle de Septembre. Self-sterile. Blossoms late; ripe mid-Aug.

Prince Englebert.-Obtained from seed of Date Prune, by Scheidweiler, Professor of Botany at Ghent, Belgium. Self-fertile. Blossom rather late; ripe iept.

Wyedale.-A plum much grown in parts of Yorkshire. Self-sterile.

Golden Transparent.-Raised by ant introduced by Messrs. Rivers in 1894. Self-fertile. D. early Oct.

Order of Flowering at the Royal Horticultural Society's Gardens.Early-Monarch, Jefferson, Denniston's Superb, Coe's Golden Drop, President. Mid-Early Rivers, Decaisne, Late Orange, Comte d'Althan's Gage. LateCzar, Pond's Seedling, Transparent Gage, Washington, Prince Englebert, Late Transparent Gage. Stint.

Note.-D. stands for dessert; C. for cooking. 


\section{CHAPTER XXYVIII.}

\section{NOTES ON THE ORIGIN OF SOME OF OUR CHERRIES.}

Gleaned by C. H. H., chiefly from "Cherries of New York," by U. P. Hendrick and four assistants (1915); Dr. Hogg's "Fruit Manual"; also from Messrs. G. Bunyard and Co.'s Fruit Catalogue, edited by Edward Bunyard; together with published results of the pollination trials on cherries at the John Innes Horticultural Research Station, Merton, Surrey; G. P. Berry's "Investigations in Cherry Orchards in Kent," in Journal of Board of Agriculture, June, 1917, pages 288 to 298; "Experiments in the Pollination of Fruit Trees," by W. J. Middlebrooke, in Journal of Board of Agriculture, August, 1915, pages 418 to 433 ; and my own experiments.

The following cherries were recommended by the late $\mathrm{Mr}$. George Bunyard for market orchards, placed in approximate order of ripening:-

\section{Early-Black Cherries.}

Earty Rivers.-Raised by T. Rivers, of Sawbridgeworth, from Early Purple Guigne. It first fruited in 1869; was introduced in 1872. Self-sterile, therefore it needs to be planted with one or more early flowering varieties, such as Baumann's May, Turk, Caroon, Frogmore Early Bigarreau. Blossoms early.

OLd BLACK HEART.-One of the oldest cherries in cultivation, still largely grown the world over, fruit soft, tree liable to Brown Rot. Blossoms early. Self-sterile.

KNIGHT'S EARLY BLACK.-Raised by $T$. A. Knight, about 1810, from seed of Bigarreau impregnated with the pollen of May Duke. Blossoms mid-scason. Selfsterile.

$$
\text { Early-White Cherries. }
$$

Frogmore Early Bigarreau.-Raised by Thomas Ingram, at the Frogmore Royal Gardens, Windsor, Berkshire, about 1850. Blossoms late. Self-sterile.

LUDWIG BIGARREAU.-Said to be a seedling obtained by Thomas Rivers, of Sawbridgeworth, about 1860.

ELton HEART.-Raised by T. A. Knight, from seed of Bigarreau or Graffion, (Yellow Spanish), with pollen of White Heart, largely grown in America, as well as in England. Somewhat self-fertile. Governor Wood suggested as a polleniser. Blossoms early.
Early-Red Cherries.

May Duke.-Mentioned by Ray, in 1688, may have originated at Médoc, in the department of Gironde, France; this variety is widely distributed in America. Slightly self-fertile. Frogmore Early Bigarreau appears to be a good polleniser for this variety. Blossoms early.

Mid-Season-White (or Yellow).

Kentish Bigarreau or Amber Heart.Very old, but one of the best market varieties. Self-sterile. Frogmore is found to be a good polleniser for this variety, also Governor Wood and Waterloo. Blossoms late.

\section{Mid-Season-Black.}

Black EAGLE. - A valuable market variety, was raised about 1806 by Miss Elizabeth Knight, daughter of Thomas Andrew Knight, at Downton Castle, Wiltshire, by fertilising Bigarreau (the Yellow Spanish, of America) with pollen of May Duke. Self-sterile. Flowers midscason.

\section{Mid-Season-Red.}

RoYal DUKE.-As for other Duke cherries, the Mazzard stock is recommended rather than Mahaleb.

\section{Late-White.}

Napoleon Bigarreat.-The leading firmfleshed, sweet cherry. Name given by Baumann, of Bolwyller, known in 1791, upright sturdy growth, good for canning; also known as Royal Ann, in U.S.A.; as Seth Lewelling, taking it across the Continent en route for America lost its label. One of the latest to flower. Somewhat self-fertile. 
Cleveland Bigarreau.-Raised by Professor J. P. Kirkland, a seedling from Yellow Spanish. Raised in the U.S.A.

Bigarreau de Mezel, or Great Bigarreau.-Found at Mezel, Puy-de-Dôme, France, by M. Ligier, previous to 1846. 110 fruits of this variety are said to have weighed over 2lbs.

Emperor Francis Bigarreau.-Of Continental origin, said to do well in Scotland.

FloRENCE.-Similar, but smaller, than Yellow Spanish, brought from Florence by a member of the Archer-Houblon family, about 1800 . Planted at Hallingbury Place, in Essex. Flower's late. Selfsterile.

WINDSOR. - A good late Bigarreau, hardy, thrives in many soils. Originated on the farm of James Dougall, Windsor, Ontario, Canada, introduced in 1881.

\section{Late-Black.}

WaterLO0. - Raised by Thomas Andrew Knight from Bigarreau (Yellow Spanish, of U.S.A.), pollinated with May Duke; fruited in 1815, a few weeks after the Battle of Waterloo. Flowers mid-season. Self-sterile. (Amber Bigarreau pollinates Waterloo satisfactorily, also Knight's Early Black.)

Black Tartarian.-Origin Russia and Western Asia, introduced into England from Russia, by Hugh Ronalds, of Brentford, in 1794, is said to have gone to Russia from Spain. Self-sterile. This variety is a favourite in America, where it grows to a large tree, lives long, and is the parent of many cross-bred cherries. Called also Circassian.

THe NoBLe. -Introduced by Messrs. Ray and Son, of Teynham, Kent, in 1900.

Turkey Heart.-An old, but good, orchard variety. Long grown in East Kent for market, flowers early, fruits well with Early Rivers.

\section{Iate-Red.}

Late Dure.-Called in France Anglaise Tardive, introduced into England by $M$. Vilmorin in 1823. Somewhat self-fertile. Morello appears to be a good polleniser for this variety.

Flemish.-Cooking, fruit when ripe when seen with sun behind tree is very beautiful. Flowers late. Self-fertile.
Kentish, or Pie Cherry.-Larger than Flemish, the stones can be pulled out with the strig. This variety was probably brought to England by Richard Harrys, fruiterer to King Henry VIII, Flowers late. Self-sterile.

Morello.-A very old variety apparently mentioned by Parkinson, in 1629, "bearing plentifully although planted against a North wall." Perfectly selffertile. Latest cherry to flower.

The above varieties placed in approximate order of ripening were recommended by the late Mr. George Bunyard for orchard planting, given in that most excellent book, "The Fruit Garden," by George Bunyard, V.M.H., and Owen Thomas, V.M.H.

\section{Notes and Other Varieties.}

The Duke cherries are considered by L. P. Hendrick to be hybrids between the sweet cherry (Prunus cerasus) and the sour cherry (Prunus avium). The Duke cherries are not much grown for market purposes in England. The Kentish and Flemish Red cherries are of the Montmorency type of cherry, and are very old cooking sorts.

The term Guigne, Gean and Geen, are derived from Guienne, a province in the South-east of France, whence these cherries were first obtained.

The term Gasteins, Gascoignes applied to cherry trees, obtained from Gascony, a province south of Guienne, they are said to have been first brought to England from France by Joan of Kent, when her husband, the Black Prince, was commanding in Guienne and Gascony.

CouronNe, or Corone.-A variety grown in Hertfordshire and Norfolk, reproduces itself from seed, the trees attain a large size; it was grown previous to 1725 , known as Kerroon, it is a small cherry, prolific, and travels well. The variety flowers very early, and appears to be a good polleniser for Early Rivers.

\section{Approximate Order of Blossoming of Cherries.}

Early.-Adam's Crown; Old Black Heart; Caroon; Early Rivers; Elton; Turk; Knight's Early Black; Victoria Black. 
Mid. - Frogmore; Amber Bigarreau; Black Eagle; Napoleon; Waterloo Black; Cleveland; Governor Wood.

Late. - Florence; Cluster; Emperor Francis; May Duke; Kentish Red; Morello; Noir de Guben; Noble.

\section{Pollination Trials.}

Out of 22 rarieties of cherries used in pollination trials at the John Innes Horticultural Institution, three were found self-fertile, Flemish Red, Late Duke and Morello: two partly self-fertile, May Duke and Archduke; and 17 were found selfsterile.

\section{American Varieties.}

Governor Wood.-A red Gean, one of the best of Professor. J. P. Kirkland's seedlings, raised in 1842, at Cleveland, Ohio; one of 30 varieties raised by Kirkland. Named after Reuben Wood, then Governor of Ohio. Self-sterile.

BiNG.-From seed of Republican, raised by Seth Lewelling, in Oregon, in 1875, named after a Chinese workman. Selfsterile.
Black Republican, -- Considered in U.S A. one of the best of the Bigarreaus. Originated in orchard of Seth Lewelling, who in 1849 brought seeds of Bigarreau, Morello and Mahaleb, to America. It is thought to be from seed of one of the Bigarreaus. Self-sterile.

LAMBERT.-Seedling tound under a Napoleon tree, by Henderson Lewelling, who about 1848, planted it in the orchard of J. H. Lambert, Milwaukee, Oregon. The Lewellings were men of indomitable courage, who in spite of every adversity, bred and grew fruits, and did a noble work to the gain of the pomology of the U.S.A.

Bing, Lambert and Napoleon, the three leading varieties in Oregon, are found to be inter-sterile. The most efficient pollenisers found were Black Tartarian, and Waterhouse, also Elton, Wood and Early Purple. Some of the Duke cherries are capable of pollinating some of the Bigarreaus, and some of the sour cherries ( $P$. cerasus) are capable of pollinating some of the Bigarreaus. 


\section{CHAPTER XXXIX.}

\section{EXPERIMENTAL WORK ON THE SELF-STERILITY OF THE APPLE.}

By W. H. Alderman, University of West Virginia.

(Abstracted by C.H.H. from the Proceedings of the American Society of Horticultural Science, 1917).

The fact has been noticed that in spite of apples and pears being generally selfsterile, there are reasonably productive orchards where the plantings are made up of a single variety, notably is this the case in "Rome Beauty" and "Baldwin" apples. In order to check whether there were any possible error in the usual methods of trial, experiments were made to consider and ascertain the following facts:-(1) Whether the conditions within paper sacks are abnormal from the standpoint of temperature and humidity; (2) individual flowers or clusters of flowers have been studied without regard to the rest of the tree, whereas in orchard conditions the tree is a unit; (3) the emasculation of bloom produces decidedly abnormal conditions-do these affect the results in any unknown way?; and (4) whether pollen from other trees of the same variety is more effective than from flowers on the same tree, even though a single flower or single tree is shown to be self-sterile within itself.

I. In a comparative test on some 20,000 blossoms of the setting of fruit on trees enclosed in muslin frames, and blossoms enclosed in paper bags, to the surprise of the experimenters the paper sacks gave the better results, as far as per cent. of set was concerned, and at least the fact is established that the bags do not hinder the setting of fruit.

In these various trials about 150,000 flowers have been pollinated and records kept.

II. The summary of 3 year's' work with Rome Beauty, York Imperial, and Wagener is that there is no advantage gained by pollinating a tree with pollen from another tree of the same variety over using pollen of the same tree. It is in- teresting to observe that Rome Beauty does not normally set as large a per cent. of its blossom as do Wagener or York Imperial. Under orchard conditions, and open to free pollination by several varieties, Rome Beauty set 4.46 per cent. of its blossoms, whereas York Imperial set 7.87 per cent., and Wagener 8.5 per cent. From this it is clear that one may not judge the relative sterility of two varieties by direct comparison of percentage of fruit set upon each, but rather by comparison of such set of fruit to the normal set of the variety. In the same way the efficiency of a mutual pollenizer may not be judged by a direct comparison of its effects upon two varieties, but rather by a comparison to the normal set of each. A study of the results of pollenation trials show clearly that while none of the varieties are entirely self-sterile, they are greatly benefited by cross fertilisation; thus in the case of Rome Beauty the percentage of set was increased threeand-a-half times, York Imperial fourteen times, and Wagener seven times. This advantage is further greatly augmented when we note that the size of the individual fruits was increased by crossing. The increase in the case of Rome Beauty was 27.8 per cent., and in York Imperial 42.7 per cent over the size of the self-pollinated fruits.

III. For 2 years experiments were made to ascertain the effect of emasculation upon the setting of the fruit; it was found that the set of fruit under emasculation conditions was more than double that where no emasculation was practised. It seems to make no difference in the results if the entire calyx and corolla are removed, merely the corolla, or if both are left practically intact, and only the anthers 
removed. The author, Mr. W. H. Alderman, thinks the explanation may be that the advantage is due to the fact that the blossoms are protected from superabundant pollination from their own pollen. Probably self-pollination frequently occurs naturally in such cases before the artificial cross-pollination is brought about; foreign pollen tubes must then actively compete with many tubes from its own pollen, with the result that the chances of cross-fertilisation are lessened; something of this sort has been proved as the result of further trials. Two methods of emasculation are employed: in (A) the petals of the unopened flower are quickly removed by one jerk with the thumb and forefinger, and then with one or two movements of a fine toothed comb the anthers are raked out without injury to the pistil; or (B) the flower is grasped firmly and a quick snap with the finger-nail just under the edge of the calyx removes calyx, corolla, and stamens, leaving pistil and receptacle clean and bare. For some varieties one method is the better adapted, for other varieties the other method.

Cross-pollination as a rule brings about an increase in number of seeds and in the weight of the fruit; by experiment with Rome Beauty, York Imperial and Wagener there are found to be two to six times as many seeds in crossed fruits as in the selfed ones. This is found to be a larger proportion than works out in practice in the orchard, which may be due to the fact that trees which set fruit with their own pollen almost invariably set fruit sparsely and consequently are able to grow these to a larger size than they otherwise would be able to do.

200 tests were made to ascertain whether there was anything toxic which prevented pollen germinating in stigmatic extract from their own pistil stigmas, but germination of all the varieties seemed equally good whether the medium was extracted from their own stigmas, or from other varieties. Good germination of apple pollen was found to take place even on the stigmatic extract from cucumber, tomato and geranium blossoms.

In 1915 an orchard of Rome Beauty that had been bearing only moderate crops, was used for A PRACTICAL TEST OF THE VALUE OF CROSS-POLLINATION. Six hives of bees were placed in a section of the orchard and sixteen trees in a block surrounding them were placed under observation. Large blooming branches of other varieties were brought in and placed upright in pails of water suspended from trees. The bees worked this block of trees thoroughly, and presumably made a great number of cross-pollinations. Another block of 16 trees at some distance was used as a check. The amount of blossom upon each block was about equal, being 81 per cent. in the bee plot and 83 per cent. in the check. Sample counts of about 9,000 blossoms showed a set of 12.6 per cent. in the bee plot, and 7.8 per cent. in the check. In another part of the orchard, where a Ben Davis tree had been planted by a mistake the set of fruit was 20 per cent. on adjacent trees. The sixteen trees fertilised by the bees produced 174 bushels. and the check block 83 bushels. These tests and those of 1916 indicate clearly the VALUE OF BEES IN AN ORCHARD. The trees in the bee plot were unquestionably more thoroughly self-fertilized than in the rest of the orchard, and this fact itself would have probably produced some gain, but it seems clear that this could not adequately explain a percentage of set double that of the normal, hence we believe the greatest gain was secured by reason of the cross pollination that must have taken place. 
CHAPTER XL.

\section{RESULTS OF THE STUDY OF THE POLLINATION OF THE APPLE.}

The following is a resumé of an article, by Professor C. C. Vincent, of Idaho University, U.S.A., published in " Better Fruit," for February, 1920. Apple trees may be unfruitful for several causes:-(1) Too vigorous wood growth; (2) defective stamens; (3) location; (4) frost injury; (5) rain during blossoming period; but the principal cause is (5) the inability of the pollen of a variety to fertilise its pistils, or self-sterility. In trials in Oregon, out of 87 varieties of apple, 59 were found to be self-sterile; 15 selffertile; and 13 partially self-fertile; but it is found, from reports in the U.S.A., that occasionally a variety may be selffertile in one locality, but self-sterile in another. Darwin wrote of a plant that was self-sterile in Brazil, but when grown in England for one or two generations became self-fertile. Thus Yellow Newtown apple is listed as self-sterile in one Government farmers' bulletin, self-fertile in Oregon, and partially self-fertile in Idaho. It is thought, therefore, in America to be almost necessary to test commercial varieties in different districts. The following is the result of tests for selffertility in 1911-12 and 1914, at the Idaho University (choosing as examples some of the better known varieties):-

\begin{tabular}{|c|c|c|}
\hline \multirow{6}{*}{$\begin{array}{l}\text { SELF-Fentile :- } \\
\text { Arkansas Beauty } \\
\text { Yellow Transparent ........... } \\
\text { Duchess of Oldenburg ..... } \\
\text { Wagener ..................... }\end{array}$} & $\begin{array}{l}\text { Percentage of } \\
\text { flowers that }\end{array}$ & $\begin{array}{c}\text { Number of } \\
\text { blossoms }\end{array}$ \\
\hline & $\begin{array}{l}\text { Howers fots. } \\
\text { set fruits. }\end{array}$ & bagged \\
\hline & .. 38.8 & 216 \\
\hline & 33.6 & 107 \\
\hline & 19.9 & 381 \\
\hline & 13.2 & \\
\hline \multicolumn{3}{|l|}{ Partially Self-Fertile :- } \\
\hline Rome Beauty & 4.6 & 10,086 \\
\hline Gravenstein & 3.5 & 826 \\
\hline Cox's Orange Pippin & 3.2 & 1,277 \\
\hline Wealthy ...................... & 3.7 & 351 \\
\hline Jonathan & 2.9 & 19,081 \\
\hline Yellow Newtown ... & 1.5 & 133 \\
\hline Ben Davis $\ldots . . . . . . . . . . .$. & 1.2 & 708 \\
\hline Bismarck .... & 1.1 & 740 \\
\hline King David ... & 0.5 & 605 \\
\hline
\end{tabular}

Spitzenburg

American Mother

Twenty Ounce Pippin ......

0.4

0.4

0.2

250

487

552

SETLF-STHRIIE :-

McIntosh Red, Northern Spy, Transcendent Crab, Winter Banana and Bellflower set no fruit at all.

Out of 50 varieties tested at Idaho University, 18 varieties showed themselves to be self-sterile, 7 self-fertile, and 25 partially self-fertile.

The results indicate that the majority of the varieties were practically selfsterile, as in many instances only one or two fruits set out of 300 or 400 blossoms enclosed, and although classed as partially self-fertile, from a practical standpoint they would be considered as selfsterile. Another surprising feature of the work is that varieties when confined to their own pollen may set a few fruits one year, and none the next, this was found with Bismarck, Cox's Orange, King David, American Mother, Rome Beauty, and Twenty-ounce Pippin.

Under favourable conditions in the open where two or more varieties are planted together, a normal set of apples is about 32 per cent. of the number of blossoms, thus very few of the varieties tried would produce a crop if planted alone in large blocks.

To ascertain whether there was any disadvantage in testing varieties in paper bags compared with enclosing a tree in a muslin cage, 1,000 to 15,000 blossoms of four varieties of apple were experimented on in both ways, with the result that about 6 per cent. of the blossoms set in the paper bags, and about 7 per cent, in the cheese-cloth tents.

As to seeds produced, generally the more seeds in a fruit the larger the fruit. Seven self-fertilised varieties produced from 0 seeds per fruit in the case of Yellow Newtown, to 3.5 seeds in Maiden's Blush, 
Rome Beauty producing with own pollen 3 seeds per fruit. Five cross-pollinated varieties produced 5.4 to 6.7 seeds per fruit. A large number of our commercial varieties of apple are self-sterile; furthermore, those that are appaj'ntly self-fertile or partially so are usually inferior in size to the fruits that set under natural conditions.

Cross-pollination trials are necessary in order to arrive at definite conclusions as to which are the best pollenisers for any commercial variety, there must be mutual affinity between varieties planted together.

Experiments were made at the Idaho Station in 1915, in order to study this important question.

Cross-Pollination Results. Percentage of fruits set to 100 blossoms

Rome Beauty X Newtown Yellaw pollen 10.0

Rome Beauty X Gravenstein pollen ...... 0.8

Newtown Yellow X Rome Beauty pollen 15.0

Newtown Yellow X Jonathan pollen ... 34.5

Jonathan X Newtown pollen ............ 27.3

Jonathan X Rome Beauty pollen ......... 25.7

Grimes Golden X Wagener pollen ...... 1.3
Grimes Golden X McIntosh pollen ....... on a

Wagener X Grimes pollen ................ qre as

Wagener X McIntosh pollen .............. 1..um

Wagener X Gravenstein pollen ............ $0.0^{\text {Ush }}$

McIntosh X Grimes Golden pollen ...... 8.0

McIntosh X Wagener pollen ........... 5.0

Spitzenburg X Grimes Golden pollen ... 35.0

Gravenstein $\mathrm{X}$ Wagener pollen ......... 22.5

These results show that certain crosses give better results than others. Some varieties would appear to be specially well suited to plant together, whilst other varieties should be avoided. To select a good polleniser (1) there should be mutual affinity (2) the two varieties must bloom at approximately the same time; (3) the varieties should be good pollen producers.

Those who have orchards just coming into bearing, or old orchards for that matter, planted with one or two varieties which are shy pollen producers, should graft one tree at least out of every ten with some variety that is an abundant pollen producer, and blooms at the same time. The final recommendation is to introduce one hive of bees to each acre of apple trees, to carry the pollen from tree to tree. 


\section{CHAPTER XLI.}

\section{PEARS AND APPLES GROWN AS CORDONS.}

A book on fruit-growing would be incomplete without mention of this most interesting method of culture, well

adapted to smallholdings and those who practise intensive culture. This method of training was advocated by Mr. Thomas

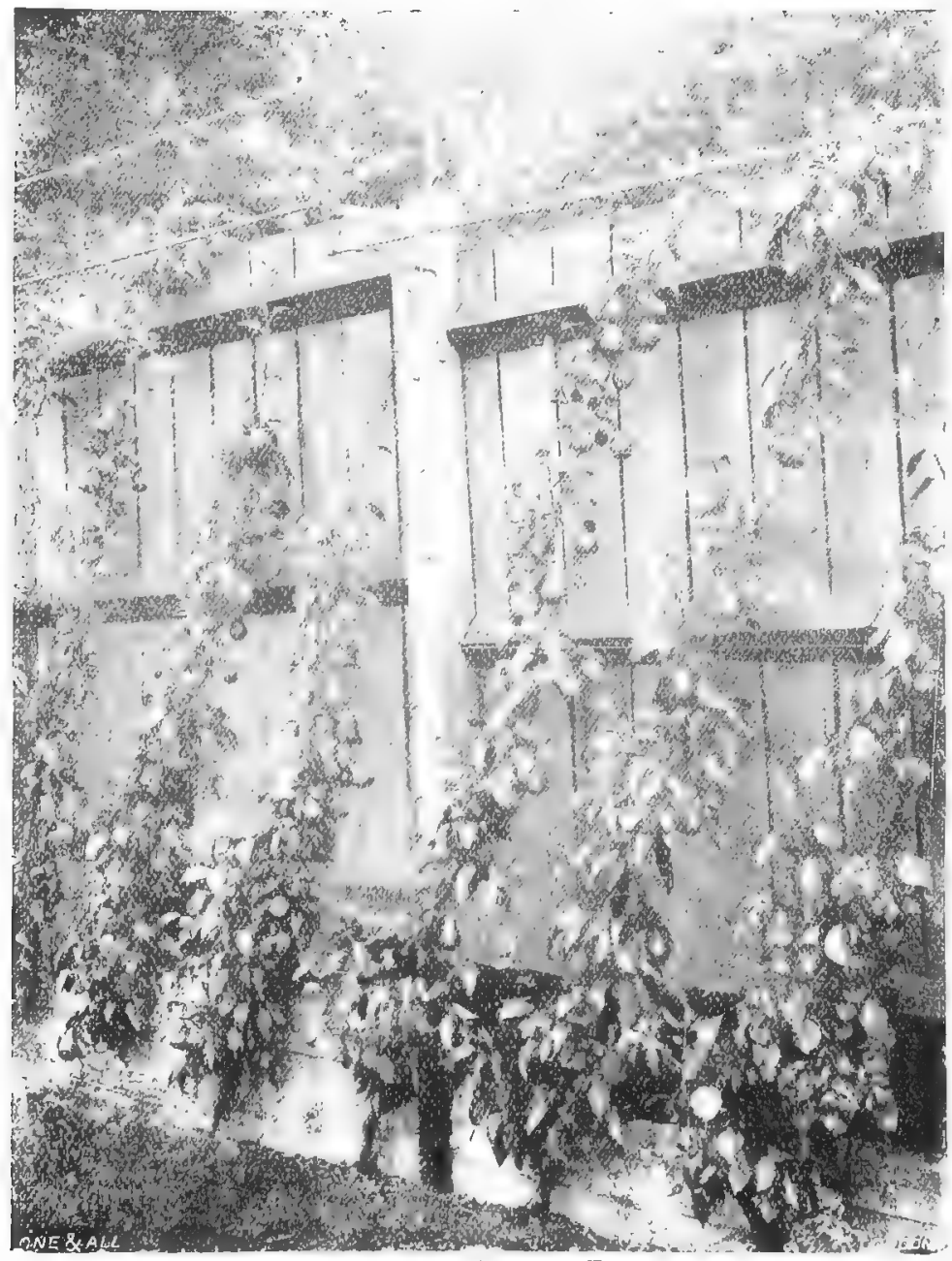

Cordon Pears against Fence.

(Block kindly lent by the Agricultural and Horticultural Association.) 
Rivers and the Rev. T. Collings Bréhaut about 1860 , and has been largely followed in the best gardens in Great Britain, excellent and plentiful fruit being obtained thereby. The method is at its best against a wail, planting the trees, which are on dwarfing stock, about 18 to 20 inches apart. Usually maidens or two-year-old trees are planted, the pears being on the quince stock and the apples on the broadleaved English Paradise or Rivers" "Nonsuch." Most cordon trees are planted with their stems set at an angle of $45 \mathrm{deg}$. against a wall, a trellis or a fence. This arrangement saves space and is considered to encourage lateral rather than terminal growth. But if the wall is high (say 12ft.) they may be planted with their stems *ertical. After the trees have set their fruit they are surface mulched with long dung or lawn grass. If they grow too grossly the trees are root pruned, which can easily be done during the winter. The object of the summer and winter pruning is to keep the fruit spurs near to the main stem. Vegetables or flowers should not be grown over their roots; the land should be kept clean and well hoed. Plum and cherry trees are not well suited to this method of growing. Pears are grown commercially as cordons in Jersey on wire trellises, but the climate in that beautifu? island is very favourable to their growth. If hops have been grubbed or loganberries discontinued, spare trellises may be available and thus utilised. Growing apples and pears as cordons is a very delightful and interesting method, by which a large number of varieties can be grown on a small area; but I do not think they are as suitable for farms or smallholdings as bush trees, because the cost is heavy for the trellis and the large number of trees required; also-at any rate in the case of apples-they do not produce larger fruit than on bush trees. To plant against walls, dwelling-houses or farm buildings, cordons are an excellent form of tree.

Most varieties of pears are suited to cordon training. With apples one would plant by preference the choicest dessert apples as cordons, such as Cox's Orange and James Grieve if found suitable; by this method the very best use is made of the land for intensive culture, but, considering the price apples and pears realise wholesale here, I do not think the method is economic for commercial fruit growing, unless, when tried on a small scale first, it is found successful. The general distance when planted against trellis is $6 \mathrm{ft}$. from row to row and $2 \mathrm{ft}$. from tree to tree; this costs about $£ 600$ per acre by the time the trees are remunerative. I recently saw a plantation of $5 \frac{1}{4}$ acres that in 1919 had yielded $£ 200$ per acre of fruit; this was, however, a very exceptional yield and at a good price.

\section{ORCHARD Houses.}

Another most delightful and interesting method of growing hardy fruits is in unheated glasshouses, but this method is a charming luxury and not suited for growing for market. 


\title{
CHAPTER XLII.
}

\section{THE RAISING OF NEW VARIETIES OF FRUIT TREES, AND EXPERIMENTS IN DOUBLE GRAFTING.}

\author{
By William CRUMp, V.M.H.
}

For many years head gardener to Earl Beauchamp at Madresfield Court, Malvern, Worcester: hire.

This is a most fascinating pursuit to an enthusiast with the necessary leisure at command, but often times, life, and ouber circumstances prevent the realisation of all the possibilities that seem within reach. It was during my early appre:lticeship, upwards of 60 years ago, that my first experiments began, and many a hedgerow plant was operated upon in my spare time, by budding, graftiog, and inarching, but it was not until aliuut 36 years ago that the real opportunity presented to carry out experiments on rroper lines, when it became part of my duty to raise some two thousand apple, pear, plum, and cherry trees for annual distribution to the farm and cottage tenantry on the Madresfield Court Estate. The details of fertilisation are so well know: as to need no comment, for every cre who attempts it has his own particular fancies as to cross fertilisation, and the sowing and treatment of the seedlings.

Having got the seedlings, it is always it matter of urgency to fruit them as early as possible, and we have proved to our own satisfaction that the small-leaved French Paradise stock gives precocity, and early fruiting wood, either budded or grafted, whichever is most convenient. This stock, however, does not give a longlived tree afterwards.

The stocks we prefer for general purposes are those known as free crab seedlings, raised from well-ripened pippins of high-coloured fruit, such as the best cider is made from, sown thinly as soon as obtainable in rows outdoors and kept safe from mice, birds, and other vermin. The first and natural inclination of these seedlings is to strike downwards with a tap root. The seedlings should be carefully lifted at the fall of the leaf, during the fir st or second season, according to growth made. The tap root is preserved intac? and replanted full length, but in a horizontal position near to the surface in a prepared trench. The tap root at this stage is young and pliable. Thus bedded early in the season, future growth will scarcely be interfered with, and an abundance of healthy fibrous roots will form throughout the entire length of the original tap root, thus securing the most desirable foundation for a future tree, The stock is the fundamental part of a good tree as upon this depends its longevity, fruitfulness and future prosperity. It is equally certain that a stock without fibrous roots cannot produce a fruitful tree, hence the careful preparation of the stock before working, in order to obtain fibrous roots, which is of the greatest importance and necessity. This is best obtained by a second transplanting into permanent position, ready for budding in the following August. We have had these prepared stocks send up a shoot 5 to 7 feet in length the first year from dormant bud; moreover, there is no root pruning ever necessary. We have repeatedly tried other methods of raising stocks, but none fqual to the above method. We have found the operations of nature and the influence of stocks and scions very subtle and uncertain. Experiments have been tried to improve the flavour, size, colour, habit, good-bearing, or long-keeping qualities, all of them, or some of them combined. Prepared stocks have been budded at the ground with Blenhein Pippin as the medium, then 
regrafted at a height of 6 or 8 feet with Cox's Orange, Cornish Gilly-flower, Ellison's Orange, Barnack Beauty and others. We appeared to have secured one or more of the improvements aimed at for a considerable time, and it was most encouraging to observe that the Blenheim blood thus infused, had in. creased the vigour and improved the appearance of some of the varieties experimented with, but before laying claim to results, or submitting the produce for the necessary hall-mark of constituted authority, we first preferred to put them through the most severe ordeal of test of time with real improvements and our own standard, which was insufficiently borne out, or not permanently fixed. The latter being the chief difficulty. We were successful in grafting an apple on to a pear stock, but this again was short lived, although I hear on good authority of a tree in this locality which did bear crops of both fruits regularly up to a recent date, but is now defunct. I also know of an apple tree that has an oak shoot growing out of the stem at $1 \frac{1}{2}$ feet from the ground, and which is said to be worked on the oak, but of this I am personally sceptical. 


\section{C'HAPTER YLIII.}

\section{THE POLLINATION, FERTILISATION AND SETTING OF FRUIT.}

The study of plants teaches us that, in order to produce seeds and fruits, pollen needs to be carried from the anthers of the stamens to the stigma of the pistil; wind and insects are the transporters of the pollen. Wind carries the pollen from the catkins to the nut flower in the case of the cob and filbert nut and the wainut; it also appears to do so largely in the case of strawberry flowers-at any rate in sunny weather. Our other hardy fruits seem to need the visit of insects to carry the pollen from the anthers to the stigmas in order to mature perfect fruits (raspberry and logan- insects for the fertilisation and maturing of their fruits.

In the cherry, plum, apple and pear a large proportion of the varieties are selfsterile, or nearly so; that is, only a small proportion of the blossoms will mature fruit with pollen of the same variety; some of the cherries are even inter-sterile-i.e., show preference as to pollen and will not set fruit with every pollen of a different variety; perhaps this is more the case, for some reason, in America than here. Even in more or less self-fertile varieties in nearly all cases a larger proportion, and

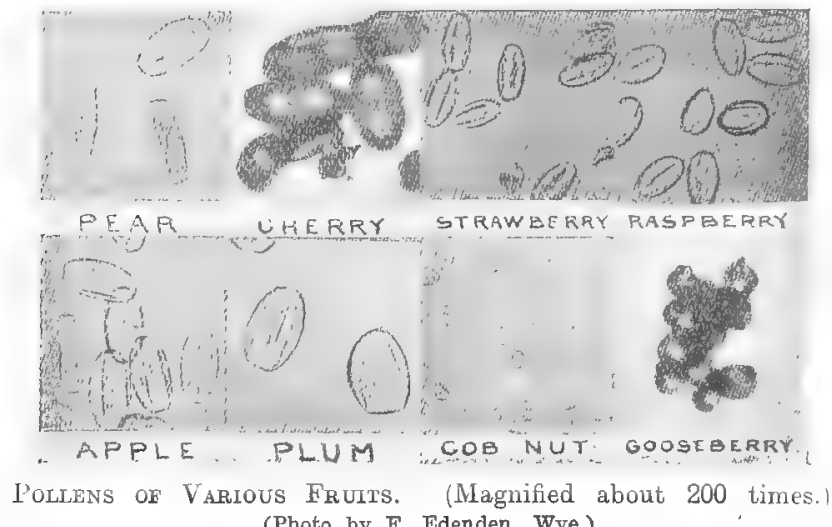

(Photo by F. Edenden, Wye.)

berry); in the gooseberry and red and black currant the pollen is glutinous (like miniature balls of boiled sago) and needs mechanical transference from the anthers to the stigma. In the plum, cherry, apple and pear one might expect the pollen to be carried from flower to flower by the wind, but observation and experiment in England, America and Australia prove that this is not the case, only exceptionally or to a very, very small extent, and that the blossoms of these trees are dependent on in many cases larger fruit, is produced with pollen of another variety. It is therefore advisable, in order to get the largest quantity and best quality of fruit in the case of the apple, pear, plum and cherry, to plant two or more varieties of the same kind of fruit in an orchard or plantation, choosing varieties that are in flower at the same time (avoiding planting very early flowering with very late flowering sorts), alternating the rows with a different variety every two or three rows, or at any rate 
planting one tree to, say, eight of a different variety. Thus, for example, Blenheim Orange and Newton Wonder apples crop well together planted in the same orchard in Worcestershire; Cox's Orange and Worcester Pearmain in the same plantation in Hertfordshire. For shy-bearing plums, as Pond's Seedling, Coe's Golden Drop, and some of the greengages, it seems advantageous to have several different varieties in the plantation for crosspollination; but commercial growers would say do not plant these varieties at all for' fear they do not bear or bear irregularly.

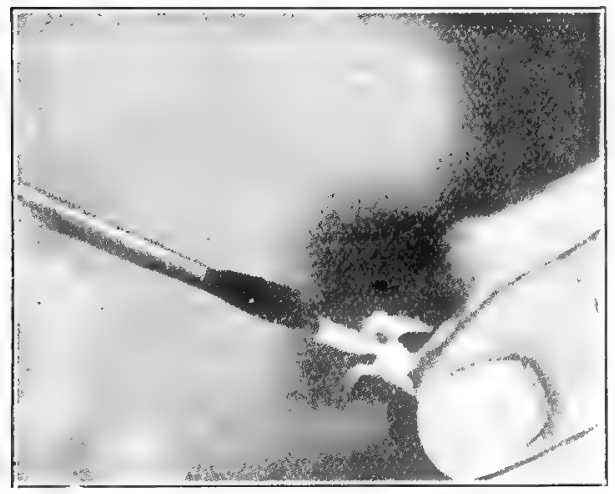

Brush Pollinating an Emasculated Apple BLossom.

From experiments at the John Innes Horticultural Institute at Merton, Surrey, and my own trials the most self-fertile plums seem to be the Pershore Yellow Egg plum, Victoria, Denniston's Superb, Pershore Purple Egg, Czar, Golden Transparent, Monarch, and Yellow Magnum Bonum; but each of these-except, perhaps, the Pershore Yellow Egg and the Pershore Purple-mature better crops if interplanted with other varieties.

In cherries, the Morello is the only very self-fertile variety and the only one that needs to have no other variety planted with it. Flemish Red is somewhat selffertile. In planting Early Rivers cherryone of the best market varieties - it is specially important to interplant one or more early-flowering varieties. Mr. G. P. Berry, Chief Inspector of Horticulture to the Ministry of Agriculture, found that an orchard where Amber Bigarreau had been planted alone was almost fruitless year by year, whereas in another orchard, in which the variety was planted with Frogmore Prolific, both varieties fruited well.

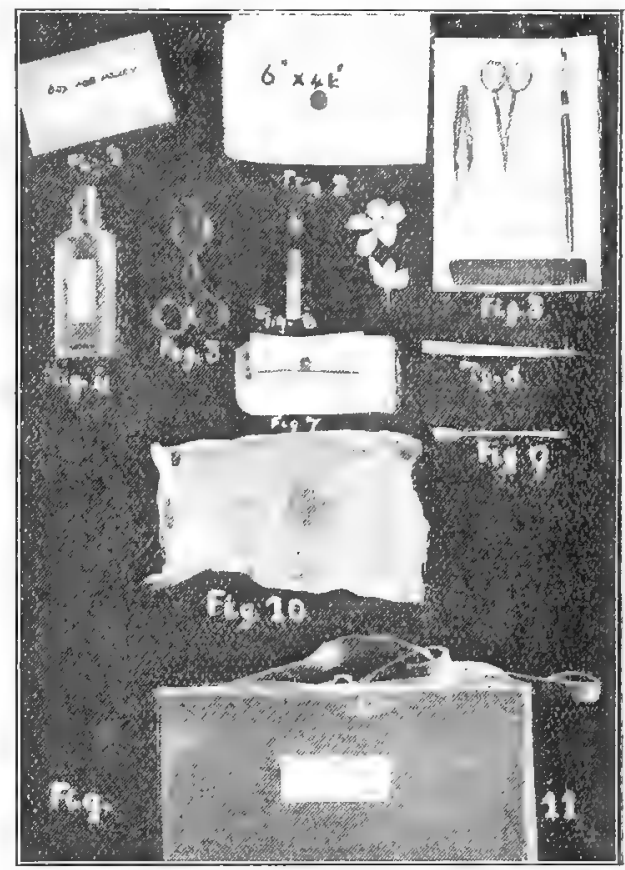

Apparatus Used tn Pollinating Experdments.

1. Box to carry flowers with pollen. 2. Paper bag. 3. Forceps, scissors, camel's-hair brush, comb. 4. Methylated spirits. 5. Magnifying glass. 6. Bottle with pollen. 7. Labels. 8. Needle in handle. 9. Spoon. 10. Muslin bag. 11. Box to carry all apparatus.

In cherries, particularly it would seem wise to have several varieties in the same orchard and to keep bees.

The order of flowering, and also experiments on self-fertility on apples and pears, have been recorded at the Royal Horticultural Society's gardens at Wisley by Mr. Fred Chittenden, F.L.S.

In pears it would be unwise to plant any single variety in block, especially certain varieties. Conference is apparently the most self-fertile pear; Hessle is apparently considerably self-fertile in Here- 
fordshire; Durondeau is slightly self-fertile; most pears seem to be self-sterile.

In apples it is advisable to interplant different varieties. It is possible that where everything is favourable a variety may be more self-fertile in one place than another. However, it seems probablo that no variety will produce the same quantity and quality planted in block as

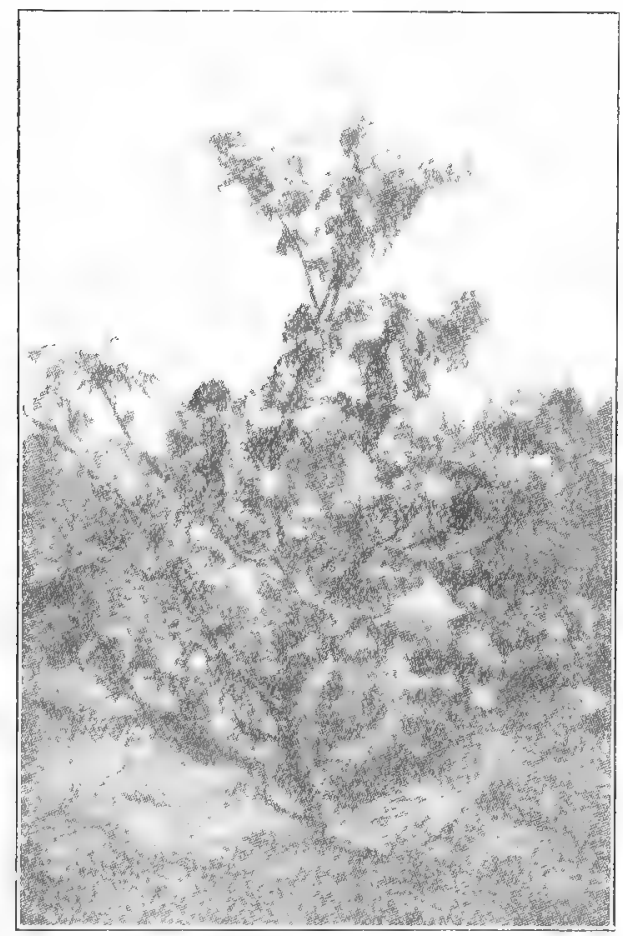

Bish of Cox's Orange Pippin,

with Bags for Trials to find the Best Polliniser.

where interplanted with one or more other varieties. Of apples that have shown themselves the most self-fertile in trial at Wisley, Merton and at Wye, may be mentioned Stirling Castle, Christmas Pearmain, Miller's Seedling, Irish Peach, Lord Derby, Lord Grosvenor, Duchess of Oldenburg, Golden Spire, King of the Pippins, Baldwin and Washington. A few of these fruits were seedless. Out of 157 varieties of apple experimented on at the
Royal Horticultural Society for three years only 57 matured any fruit with own pollen.

A consideration of importance is whether any and all varieties of the same fruit answer equally well for crosspollinating, or whether there is preference and better results with some crosses than with others. To answer this question requires long and patient experiment and, of equal importance, careful observation in orchards and plantations in different parts of the country.

Now as to insect visitors. Personally, I have a great admiration (in spite of many stings) for the hive bees. To the bumble bees I almost take off my hat when I see them, and value the work of the other smaller wild bees, but I think flies chiefly play and beetles eat the different parts of the blossoms.

Insect Visttors to Fruit Blosisoms.

The following is a summary of notes on insects seen by me visiting the flowers of the following fruits. In 1912 they were chiefly taken at Sidmouth, in Devon; in 1919 at Wye, Kent; and in 1921 at Pershore, in Worcestershire:- -

PEACH.-1912, March 14 to April 1; and 1921, March 15 to April 5-9 hive bees, 5 bumble bees, 2 bluebottle flies, one beetle, 2 other insects.

Pear.-1912, April 12 to 25; 1921, March 21 to April 12-164 hive bees, 2 bumble bees, 5 smaller wild bees, 2 wasps, if bluebottle flies, 2 other flies, 2 midge: . one white butterfly.

Puum.-1912, March 29 to April 30; 1921, March 25 to April 11-10 hive bees, 14 bumble bees, 2 smaller wild bees, 1 fly.

Gooseberry.-1912, April 3 to May 2; 1921. March 24 to April 19-55 hive bees, 9 bumble bees, 1 smaller wild bee, 1 wasp, 1 bluebottle fly.

Red Currant.-1912, April 19 and 20-10 hive bees, 1 small wild bee.

Cherfix.-1912, March 30 to April 25; 1921, March 30 to April 25-94 hive bees, 72 bumble bees, 1 other wild bee, 1 spider.

Blact Currant.-1912, April 19 to 27; 1921, March 30 to April 30-36 hive 
bees, 12 bumble bees, 5 smaller wild bees, 1 other insect.

Apple.-1912, April 19 to May 11: 1919, May 7 to 26 ; 1921. April 5 to May $14-$ 263 hive bees, 36 bumble bees, 21

by Mr. H. C. Chapelow) -797 hive bees, 32 bumble and other wild bees, 24 flies and other insects.

LoganberRy.-1912. May 19 to 30 (observed by Mr. H. C. Chapelow)-1,292
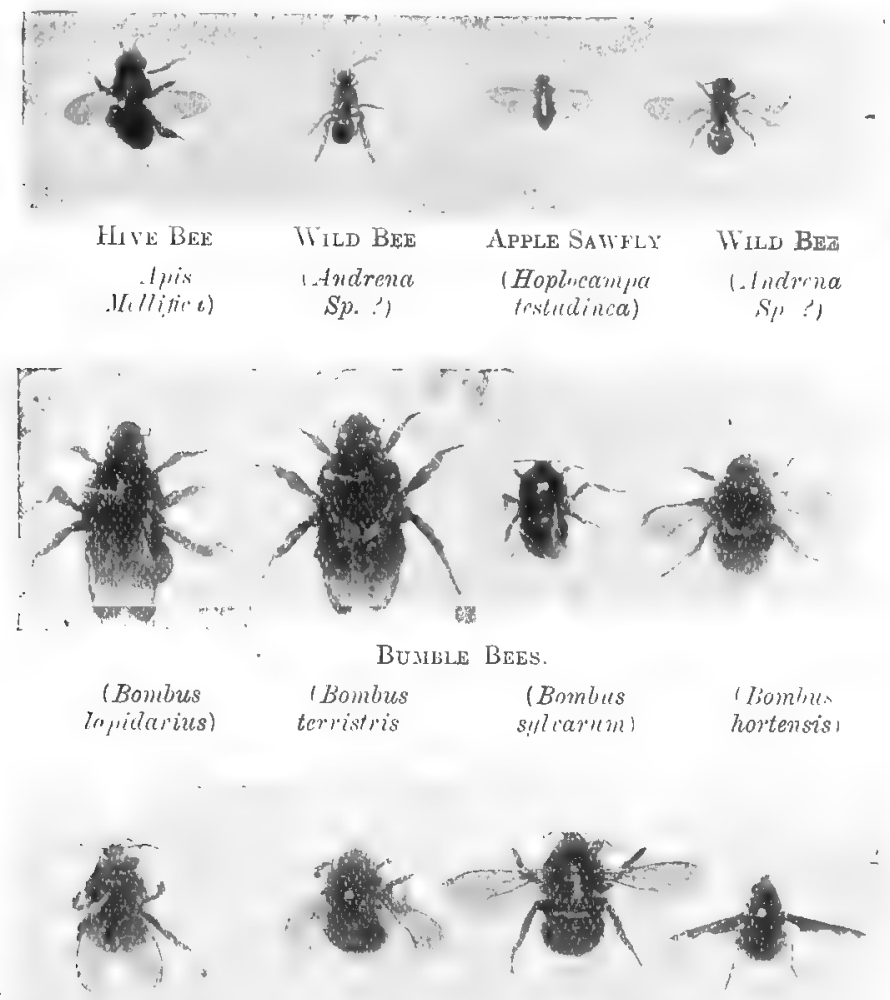

Brale E BeEs.

$\begin{array}{cccc}\text { (Bumbus } & \text { (Lumlus } & \text { (Psillimus } & \text { (Bumlinlius } \\ \text { derhamellus) } & \text { muscorum) } & \text { barbutillus) } & \text { major) }\end{array}$

Insect Visitors of the Apple. (Caught by C. F. Vetch and C. H. Hooper.) Kindly named by $F$. V. Theobald.

smaller wild bees, 51 ants, 23 flies, 3 earwigs, 2 thrips, 104 beetles (including 24 weevils, small brown, steel-blue and tiny black beetles, also 1 click beetle).

STRAWBerRY.-1912-Visited by few insects, though hives of bees near.

Raspberri, - 1912, May 21 to 30 (obscrved hive bees, 61 bumble and other wild bees, 79 files and other insects.

Quince.-1912, May 1 to 10-Four hive bees, many ants.

These notes are rough, only, a few minutes a day being devoted to the observation. It needs an eye like a haw's 
to recognise some of the insects, and to catch small wild bees, flies, etc., requires a nimble entomologist. In $1908 \mathrm{Mr}$. C. F, $\nabla$ etch and I tried catching insects we saw visiting apple blossoms. Professor F. V Theobald kindly named them for me. They included: (1) Apis mellifica (hive bee); (2) Bombus lapidarius (the stone bumble bee); (3) Bombus terristris (the large earth bumble bee); (4) Bombus hortorum (the small garden bumble bee). (5) Bombus sylvarum (the shrill carder bee): (6) Borabus derhamellus (the redshanked carder bee); (7) Bombus muscorum (the large carder bee); (8) Psithyrus barbutellus (a parasite to bumble bees); (9) Bombylius major (a fly): (10 and 11) Andrena Sp. (shorttongued bees); (12) Hoplocampa tertredinea (apple sawfly). 


\section{( IIALTER YLIV}

\section{PLACK CURRANT CUTTINGE.}

In a lruit-growing tour I made in the is cist of England this spring (1921), the finest young black currant plants I saw were at Hilltop, Ledbury, Herefordshir'?. Mr. H. S. W. Bickham has kindly, at my p'quest, given me an account of his method of raising his young plants, which is as follows:- The cuttings are taken towards the end of October (whenever possible), while the foliage is still on them. The euttings are cut to as near 8 inches as: possible. The land is well manured and cultivated previously; a trench is cut out either entirely by spade or with a plough (generally) and the rough side and bottom "touched up" with the spade.

The cuttings are then placed in, 6 inches being covered with soil and very firmly trodden in; this leaves about 2 inches (roughly two eyes) above ground.

Or if we are in a hurry the shoots are placcd in the trench and then cut off later on at our leisure, leaving two eyes showing above ground.

Any shoot which is long and strong cnough to make two or more cuttings is cut down on planting and the balance is planted.

The cuttings are placed about 4ins. apart in the trench. We always leave $2 \mathrm{ft}$. 9ins, or $3 \mathrm{ft}$, from row to row to enable us to cultivate as much as possible with'a horse and Planet Junior cultivator.

In November or December the moulding plough is run up the rows and the earth is thereby pressed up to the struck cuttings or established plants.

If the land is clean before planting the cuttings, four hand hoeings each year ought to be enough to keep weeds down in a normal season.

We do not generally transplant, but cut back the shoots hard every year, and the moulding plough tends to raise the earth round the plants and thereby produce a low "stool" (i.e., a plant without a leg).
When planting out into a "permanent plant" we always sink each plant about two or three inches below the nursery line. This causes a good " stool" with cyess breaking out just below the groundlevel.

I only grow the true Baldwin now. I have grown a good many other varieties, but would rather have a Baldwin plant for six years and then grub it for gall mite or reversion than any other for 12 years.

My stock is practically, if not entirely, free from big bud, and it is "rogued" evcry year by the simple and easy method of leaving one shoot intact on every plant (all the others being cut down hard). By this method one can tell by the blossoms at a glance, in addition to the foliage, whether the plant is reverting or not; whereas, if all the shoots are cut clown, the foliage on the young shoots which are thrown up is so vigorous, even on reverted plants, that it is almost impossible to tell a rogue-unless, of course, the plant is badly "verted."

In addition to gall mite, Baldwins are very subject to attacks of "green bug," but this is easily wiped out by spraying at the proper time (i.e., before the insect has grown large enough to be lively) with such fluids as nicotine, Nicotex, McDougall's No. 2 wash with Polvo or their Katakilla.

In addition to pit or old yard manure, we largely use soot (up to 3 tons per acre) and meat meals. Lime is also added at not less than 2 tons per acre at an application.

Many growers cut their cuttings 12ins. in length (some even up to 15ins.), sinking them into the ground 9 or 10 or 12 ins. We have found on this soil that at these lengths the roots are liable to be concentrated towards the bottom of the plants 
when they are lifted, leaving a big blank space of several inches with no root fibres. Whereas, by only allowing 6ins. underground, we get a mass of fibrous roots over the entire length of the 6ins.

Moreover, if we purchase or grow plants with a long bare stem, when we come to plant them out in their permanent quar- ters we find that we either have to get the holes out very deep to take them, plus the 2ins. or 3ins. which we always sink them below the original nursery level, or we have to cut off the greater portion of the roots to get the plant into a normally deep hole, plus the 2ins. or 3ins. mentioned above.

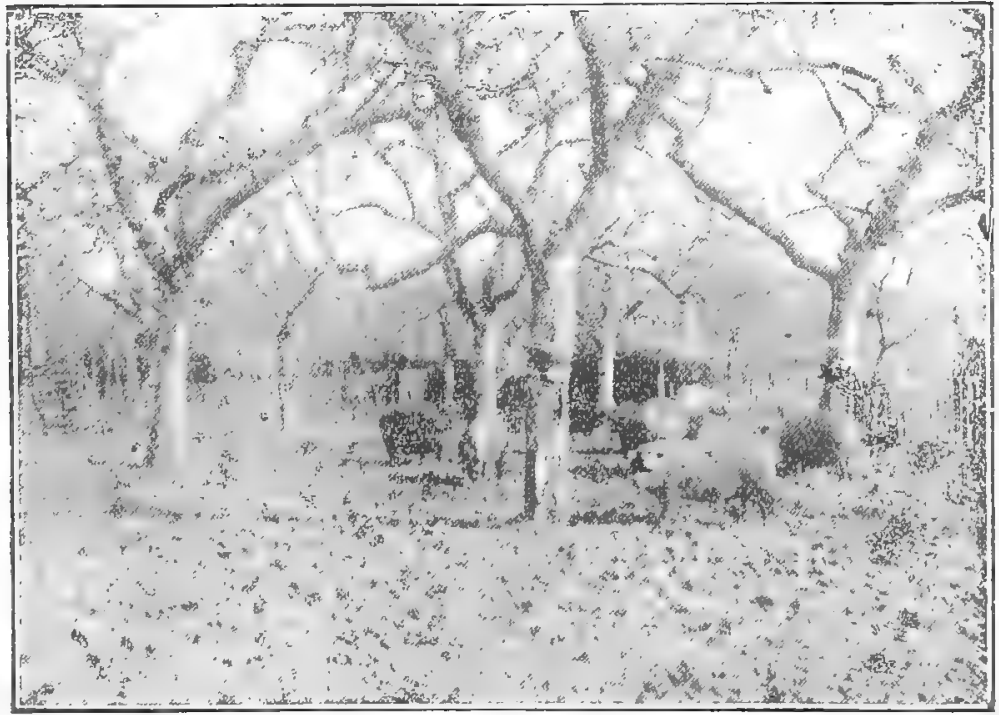

Pigs in Cherry Orchard. 


\section{C'HAPTER XLV}

\section{REGRAFTING OF FRUIT TREES.}

After patiently waiting several years it is often found that the variety of apple or pear or other fruit for some reason is unsatisfactory; perhaps the soil does not suit it, the tree somehow does not crop properly, or the fruit is found to be unsuitable for market purposes, and it is thought better to regraft it.

The stocks to be regrafted should be healthy, or time and space will be wasted.

The scions for grafting should be in a more backward condition than the stock, so that twigs to be used for grafting are

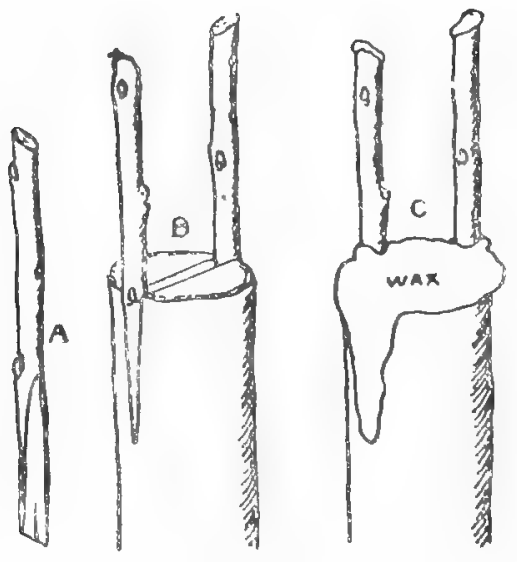

CLET T - GRAFT.

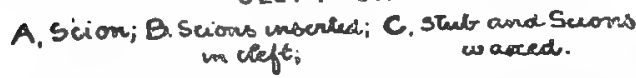

cut in early winter and placed with their lower ends deep in the ground to retain their moisture, behind a north wall so as to retard their growth in spring.

Cleft GraFt.

The necessaries for the work are: (1) a sharp, fine-toothed pruning saw, with which to make a clean cut of the limbs to be grafted; (2) a grafting chisel, with which to split and hold open the limb for the insertion of the scion; (3) a small mallet; (4) grafting wax or grafting clay; and (5) scions.

A good recipe for grafting wax, as used in Canada, is the following:-Resin, four parts by weight; beeswax, two parts; tallow, one part. Melt together and pour into a pail of cold water, then grease the hands and pull and work it until it is nearly white.

In dealing with an old tree the regrafting should not all be done in one year, but in two or more years, so as not to upset the constitution of the tree. For cleft grafting the limbs should be about two inches in diameter, as the wounds then soon heal over.

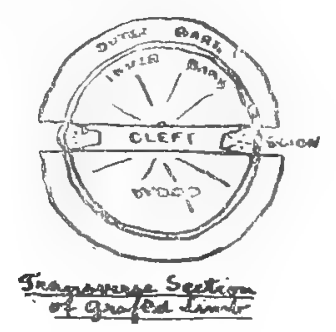

Top grafting trees require skill in making the small wedge-shaped portion of the scion. It is done by the use of a sharp knife, making a single drawing cut for each side, so as to make a perfect wedge, usually leaving the one side a little thicker than the other to ensure close contact. Then, while the split wood is held apart with the chisel, the two scions are put in place. Care is required, in placing the scion in the cut, that the inner bark (or cambium layer) of both stock and scion may be in contact with each other in order to make a perfect union.

The contact of these two actively living portions is vital for successful grafting. 
When the scions are put in place cover every portion of the cut surface of scion and limb with grafting wax, so as to exclude rain and the drying effect of the air.

Two scions are usually inserted as giving two chances of success, and also to help heal the wound, though usually only one graft is eventually wanted.

\section{Rind Giaft.}

Cleft grafting is the method of regrafting chiefly adopted in Canada. In Kent what is known as "crown grafting" is more usual; the branch is headed off and the stock is slit through the bark in one or more places and one or more scions inserted, carefully fitted, then the stock is tied round firmly with bast to hold the grafts in position, and the whole is covered with grafting clay or wax as described in cleft grafting.

In Worcestershire men skilled at grafting come round to the farmers and do any grafting required. The arrangement used to be that they should be paid 1d. for each successful graft, after waiting to see results.

\section{Saddle Graft.}

Probably the most perfect form of grafting is the saddle graft, applicable to small wood and also to stocks of large diameter. In this case a tongue is made to cross over the stock to link it with the cambium on the farther side, as well as the portion inserted between the bark and the wood.
This method takes a little longer than ordinary whip grafting. As to the time taken for grafting, the foreman on $\mathrm{Mr}$. Hugh Mumford's "Three Springs Farm" at Pershore can graft 100 apple stocks in one hour, with a man tying after him and a boy following putting on clay. Plums take a little longer than apples -60 per hour, 99 per cent. taking.

In recent years many trees of Cox's Orange Pippin and other varieties found unsuitable have been successfully regrafted with Bramley or Newton Wonder, and unsuitable pears with Conference or Hessle. I know of one excellent cherry orchard where many of the trees were regrafted. Some plums will regraft, but in stone fruit there is liability of starting "gumming."

Damsons and a few varieties of plums are benefited by severe heading back of the branches, say every ten years, which renders them far more fruitful.

Young nursery fruit stock is propagated by whip grafting or by budding, the methods of which are described in almost every book on gardening, so I will not give further space to it here, but will add that, from what I have seen, very few fruit growers raise as good young trees as nurserymen do; also, that the knowledge of the most suitable stock for a variety needs to be known, or a mistake may be made which wastes time and money in the formation of the plantation. 


\title{
CHAPTER XLVI. \\ GRADING AND PACKING OF FRUIT FOR MARKET.
}

\author{
By T. J. Poupart.
}

It is almost with fear and trembling that anyone dare approach this subject at any time, but it was never so essential that English growers should grade and pack well as it is to-day, with growers in all distant parts of the world competing for the world's markets with produce graded and packed as the consumer requires it. So much has been said and written about the packing and grading of fruit that growers are apt to resent further pronouncements on the topic.

What is here offered for the perusal and consideration of growers is not so much in the nature of advice; rather it is a collection of opinions resultant upon observations made in the course of handling large quantities of fruit during many variable seasons.

If experience, admittedly the best of all tutors, be highly valued, then the opinion of a salesman who has closely watched the preferences of a large community of buyers must at least be worth consideration. Should just a few growers benefit by the lessons learnt at Covent Garden, the writer of these notes will not have laboured in vain. The underlying principle which has actuated these notes might thus be epitomised "What Sells Best," or, in other words, "What the Consumer demands."

GOOSEBERRIES.-Most growers do the right thing in regard to gooseberries. Very early fruit sells best, for a few only, in 6lbs. chips, to be followed almost directly with pecks containing 12lbs., these again to be followed as soon as prices reach a reasonable level by halfbushels containing 28lbs. Some growers may ask, why 28lbs. ? the answer being $241 \mathrm{bs}$. of gooseberries does not as a rule fill a half-bushel, and a basket that has the appearance of being badly filled is not in favour with buyers. Ripe berries, either yellow or red, in the customary half-bushel baskets, but special dessert varieties, such as "White Lion," realise better in punnets of $11 \mathrm{~b}$. or chip handles of 6 lbs.

Strawberries. - The first recommendation in regard to strawberries is to forget that the peck has ever existed. It is old-fashioned and is obsolete. Several lots of fruit of exactly the same

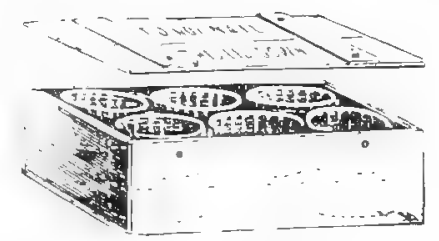

quality have always shown a worse net result when packed in pecks than in the packages about to be recommended. Please bear in mind these remarks concern strawberries only, and subsequent recommendations of the peck must not be considered contradictory.

(1) Finest fruit grown within a distance which admits of conveyance to market by road is best suited to punnets. It should be packed in punnets of $11 b$. eract weight, the punnets to be placed in cases or boxes holding 12 or 24 .

(2) Good medium fruit is sold to advantage in 4lbs, to 6lbs chips. These should take the place of pecks. Growers may cavil at the expenditure of a few pence on a package, but it will repay them handsomely, as a better price is obtained for the fruit, and the salesman will be able to show better results.

Each grower should take special care so as to mark his consignments that they are easily distinguishable. To achieve 
this object a label should be slipped through the wicker rim of the basket in a manner showing clearly who is the sender of the fruit. Whether this is done by means of name, number or initial is a matter of arrangement between sender and salesman, but it is most important that the labelling be done in the clearest possible manner.

Of chips, the square variety with the wooden handle, as illustrated herewith,

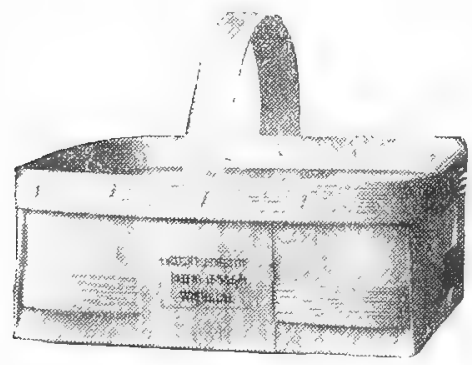

is the most suitable. The handle can be marked with pencil or rubber stamp with the distinguishing sign of the grower.

I would here like to impress upon growers the advisability of adhering to a $41 \mathrm{bs}$. chip and to see that the weight is contained. A 4lbs. actual, not nominal, weight is the package which finds favour with buyers.

(3) Growers may rest assured that chips will show much better net results than pecks, especially when there are large quantities of fruit to be marketed. Small strawberries and fruit intended for jam should be packed in tubs.

RASPBERRIES.-Only best dessert fruit should be marketed with the stalks adhering. It is as well not to send too great a proportion of raspberries with stalks, as in the event of the demand for such fruit being somewhat slack much difficulty is experienced in selling it for culinary purposes. The package to be recommended for dessert raspberries is the $11 \mathrm{~b}$. punnet packed in boxes of 6 or 12 .

Cooking raspberries are best liked by buyers in $41 \mathrm{lbs}$. or 6lbs. chips. It is highly advisable to always send this fruit in nonreturnables, except, of course, in the case of that required for jam, in which case the tub is quite the most suitable vehicle.

Cherries.-Adherence to old customs is perhaps as well in the packing of cherries. The time-honoured half-bushel of about $241 \mathrm{bs}$. for ordinary varieties and the $12 \mathrm{lbs}$. peck for kinds such as Napoleon, Elton and large soft black cherries have both fulfilled their purpose effectively. In the ordinary way it is safe to say that in a normal season the half-bushel is the only package now recognised by buyers as entirely satisfactory. Pecks ought only to be used if and when cherries happen to be in exceptionally short supply and the quality being marketed is very high-class. The chip basket for cherries other than, perhaps, Morellos is a thing of the past. There is another package coming into use to some small extent which, to my mind, is not as satisfactory as the half-bushel, and that is the bonnet. This, however, deserves mention. Chips, however, are a useful package for Morello cherries.

Plums.-Again the punnet has its use, but only for wall fruit of the highest class. Specially fine handsome plums are displayed in punnets containing only one layer of fruit. Time after time such fruit packed as described has sold to great advantage.

For the bulk of plums there is no more suitable package than the half-bushel containing 24-28lbs. Incidentally, it may be remarked that growers with a reputation for giving good weight are well repaid for their generosity, which automatically becomes its own reward. Some Middlesex growers have used boxes of a capacity equivalent to half-bushels. These may be suitable on occasions for fruit of a very hard nature, but as a rule it is better to pack plums in baskets, which are much more pliable than boxes. It has been found that boxes are lacking in the slight elasticity characteristic of baskets, and therefore the fruit suffers from sudden contact against a hard and nonresilient package.

Ripe Victorias, large greengages, Prince of Wales and other plums of a showy nature may be packed in pecks of about 12lbs., but great care is necessary in selecting fruit for such treatment.

Pears. - Specially fine fruits, such 
the Doyenné du Comice and other choicn varietil's, are shown and sold to best ar' vantage in trays contrining from 6 to 1 : pears, carefully wrapped in pink pape' ' sufficient to cover half of each specimen. All the fruit should rest on fine quality aspen wood wool. In every box there must be placed a ticket clearly indicating the name of the grower and the number of pears contained.

Other choice dessert kinds may br. wacked either in half-bushels or the more modern " ? bushel" box, measuring $20 \mathrm{in}$. $x$ 11in. $x$ 5in., capable of holding from 48 to 100 pears in two layers. This is a copy of an American illustration showing the fruit wrapped in papers. For the English trade these wrappers are not necessary.

Common and cheapest varieties have proved sufficiently remunerative in bushels. At the moment there is nothing better in vogue. If a prophecy may be ventured, it is that in the course of a few years the bushel box will supersede the basket, though at the moment baskets are more in favour with growers. Growers who contemplate using boxes will be well advised to cover one end of the box with an artistic design (registered), which will act as a label and at the same time indicals the quantity of fruit in the package.

\section{Special Notes on the Use of Leaves, Grass, etc.}

Gooseberries. - Pack with rhubarb leaves or cabbage leaves, or long grass, cross sticks on top, chips to be strung crosswise.

RASPBERRIES.-Wherever possible put no packing on top, but when sending by rail use paper covers only if absolutely necessary. If practical to avoid use of paper covers, profit by such avoidance because of the juice which is almost certain to stain many of the papers, thus making the sale of the fruit more difficult. Invariably raspberries without paper covers sell best.

StrawberRIES. - Same remarks as to raspberries.

Plums.-Cover with blue paper, fasten down with two or three sticks, flat ones for preference. If the fruit is in very hard condition a little green grass or nettles may be used. When two or three varieties are sent in one consignment it may be well to use varied coloured wrappings, so that the salesman may quickly discern the different qualities of fruit.

Cherries. - Treat in the same manner as plums.

\section{Apples in Boxes.}

To deal adequately with this topic would require volumes, but owing to limitations of space indulgence is craved for a somewhat brief expression of opinion on this all-important question, the solution of which is of rital importance to the future of apple culture in the British Isles.

Ill-timed and oft-repeated censure is apt to nauseate, so just for once it may be well to pass over the shortcomings of the English apple-grower. After all, such are mostly sins of the past, for the majority of orchardists of to-day grow good, saleable varieties of apples, the quality of which is altogether satisfactory. Then why lose much of the trade to which they are justly entitled in their own markets merely by reason of unattractive packing?

In the race for supremacy the applrgrower must increase his pace to equal, if not excel, that of his foreign and colonial rivals who have realised that packing has a most important bearing upon the sale of fruit, and have studied its points in detail with satisfactory results. Then let the British grower do likewise.

It was in the apple season of 1911 that the first serious efforts were made to combat the increasing tendency on the part of the buyers to purchase colonial and American apples. In other words, not until that year did several leading growers decide to give the box packing a fair trial. Hitherto just a few sporadic efforts have been made, such as the marketing of choice Cox's Orange Pippins in peach trays, a mode which is perhaps the best for really fine fruit. First-grade Cox's or King Pippins, or any other specially good large dessert fruit, show up well in trays of the following dimensions:-

\section{Dimensions of Box and Number of Fruits.}

These trays should be used for that class and grade of fruit and no other. For 
the benefit of those who may not have had experience in this class of work, it is permissible to explain that fruit may be packed tightly up to 24 in number, each apple being half wrapped in pink paper, there being a little wisp of fine aspen wood wool between each specimen.

Every kind of apple is not suitable for box packing. For example, the Bramley's Seed!ing, one of the best, if not thi varieties, provided the appearance is good. No definite law on the subject can be laid down. It is nothing more or less than a question of showing fruit to best advantage, and surely by this time the principle that the eye must be pleased in matters fruitarian is accepted on all sides. Further to dilate on that topic is but to labour the obvious, except, perhaps, to point out that no fruit smaller

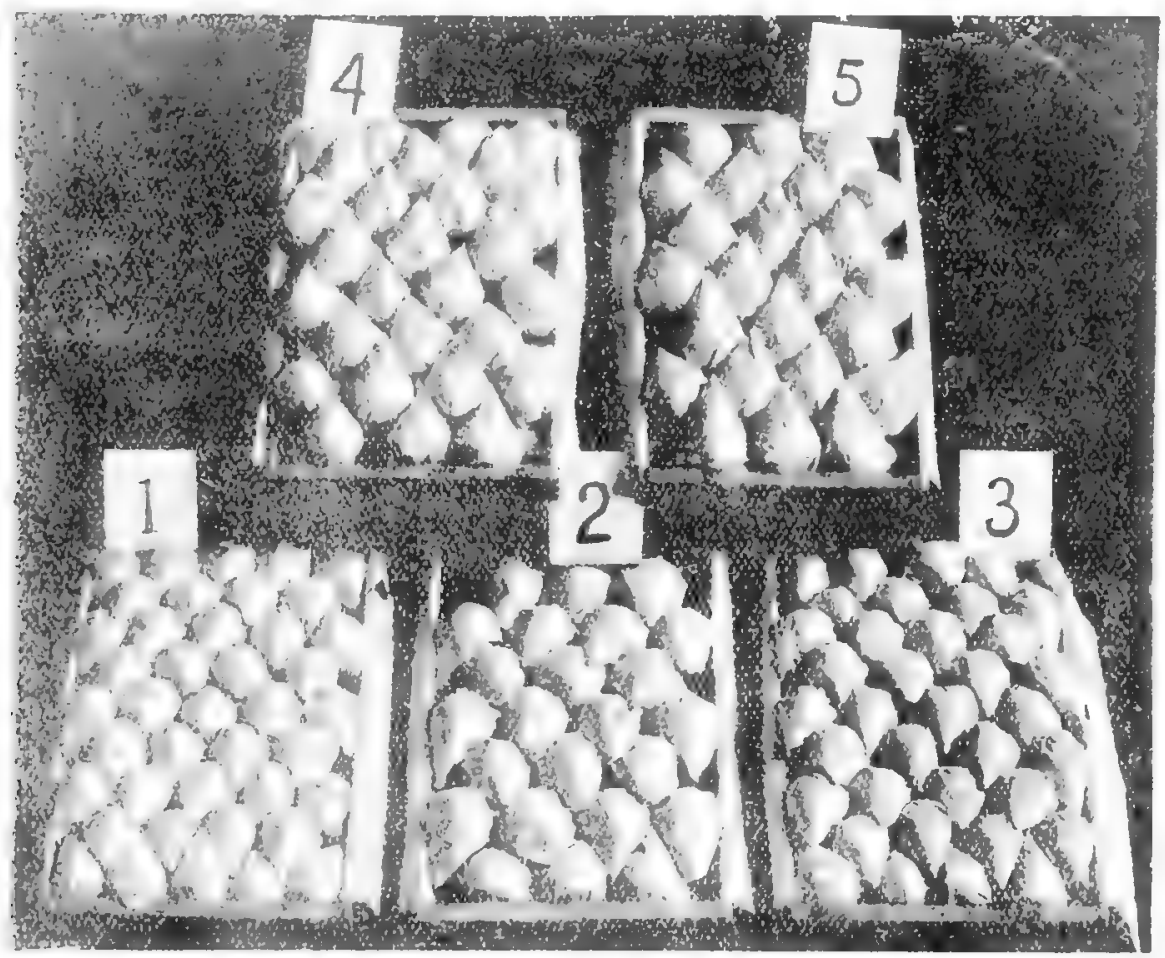

Box 1, 100 Pears. Box 2, 60 Pears. Bux 3. 90 Pears. Box 4, 70 Pears Box 5, 48 Pears.

finest modern cooking apple, is not well adapted to the purpose. It is rather awkwardly shaped, and does not present a nice even appearance; but there are exceptions even in the case of the Bramley, which, when specially shapely firuit, can with advantage be put into boxes. Irregularity must always be avoided.

Growers may ask the kinds of apples suitable for box packing. Practically all than that which works out at $4 \frac{1}{2}$ tiers, or from 150 to 170 apples, is to be included in that category of box-fruit. In preparing the box, remember to line with white or blue paper, the former for preference. The paper must just reach to the top of the sides and end of box. Before nailing on the lid place a sheet of paper over the top of fruit. The box in general use is the "standard apple box" recom- 
mended by the Federation of British (xrowers. The measurements of this are 18ins. by $11 \frac{1}{2}$ ins. by $10 \frac{1}{2}$ ins. inside. Speci-

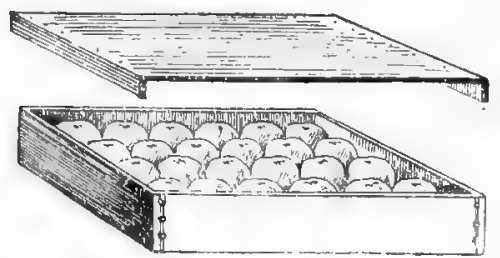

fication: Two ends, $11 \frac{1}{2}$ ins. by $10 \frac{1}{2}$ ins. by $\frac{3}{4}$ in. : two sides, $19 \frac{1}{2}$ ins. by $10 \frac{1}{2}$ ins. by $5 / 16$ in.; two tops and bottoms, 1913ins. by 11ins. by $3 / 16$ in.; four cleats, 11ins. by $\frac{3}{x}$ in. bv $\frac{1}{1}$ in.

\section{Lessons from Abroad.}

Imericans and Colonials have made a great success of apple culture. They have studied it from beginning to end, and not a little of their prosperity is due to the careful attention paid to grading and ansure uniformity of appearance, neatness and protection from bruising. The purpose of careful packing is to make the box of fruit as attractive as possible to the purchaser, and obtain thereby for it the highest possible place." A definition somewhat lengthy and verbose, yet easily understood. Then let it be adopted by English apple-growers.

Great care should be taken in the gathering to avoid bruising or in any way damaging the fruit. Many precautions can be taken to avoid injury, and pickers should be taught that although the apple is a hardy fruit it is not of the nature of pig-iron. Competent labour is always worth securing.

The two principal methods of packing apples in boxes are (1) the diagonal pack, (2) the square pack, of which the illustra. tions convey a comprehensive explanation. In an able article which appeared in "Better Fruit" some years ago, Mr. C. C. Vincent, of Idaho University,

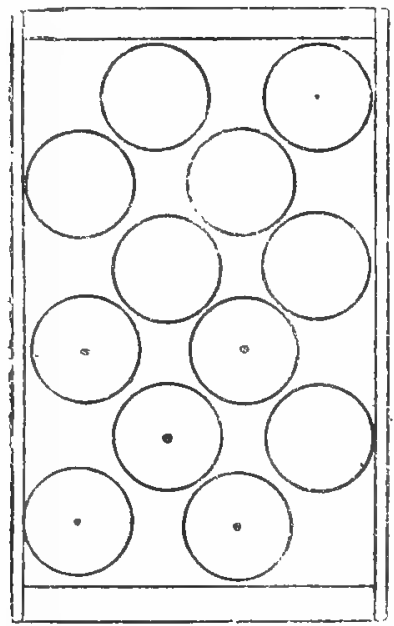

Box Containing 48 Apples. Box Containing

packing. That being so, it behoves us in this country to learn the habits and methods of those who have succeeded in our markets. A well-known American apple expert once described packing as "the classification of fruit in the proper sizes by placing fruit of the same size solidly into boxes in such a manner as to

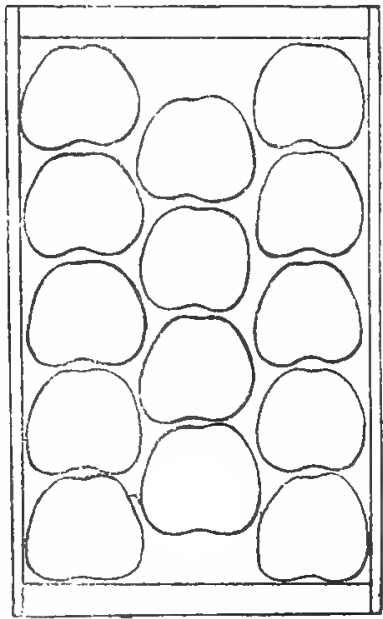

45 Apples. Box Containing 41 Apples.
U.S.A., wrote the following commentary on the subject of these two kinds of packing, which is as applicable to-day as when written. He said :-

"At the present time there are two styles of packs, known to the trade as the straight and diagonal. The straight pack is so called because the rows run straight 
across the box. This pack includes the three, four and five-tier apples. It is very neat in appearance, but rather severe, as each apple tends to be pressed against surrounding apples. The diagonal pack is so termed because the apples run diagonally with the edge of the box. Two advantages of this pack are: First, it accommodates sizes that do not adapt themselves to the straight pack; secondly, there is less danger of the apples bruising in transit, as they adjust themselves more readily to the space in the box when pressure is brought to bear. All two and onehalf, three and one-half and four and onehalf tier apples can be placed in the diagonal pack. Growers in almost all the prominent fruit sections are discouraging
$72,80,88$; 31-tier apples in the special, $96,104,112,120 ; 4$-tier apples in the standard, 96, 104, 112, 120; 4-tier apples in

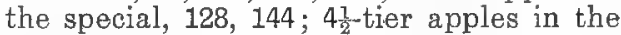

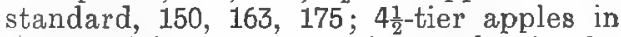
the special, 185, 200; 5-tier apples in the special, 200, 225. Unless the apples have been properly graded beforehand, no such system of classification can be obtained.

"Very little trouble will be experienced in starting the straight packs if the apples have been graded properIy. With the 3-tier pack three apples are required to fill up the space across the bottom of the box. There are also three layers in depth. See the box designated as 3 -tier in the illustration. This photograph shows the top layers of six boxes

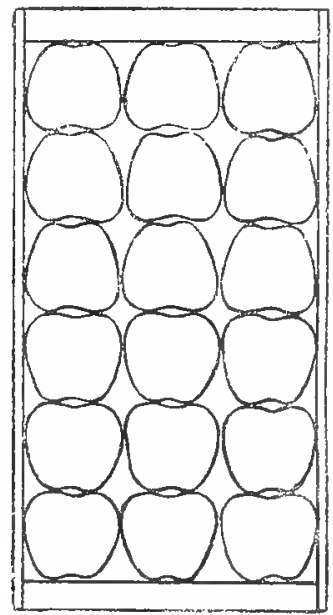

Box Containing 54 Apples.

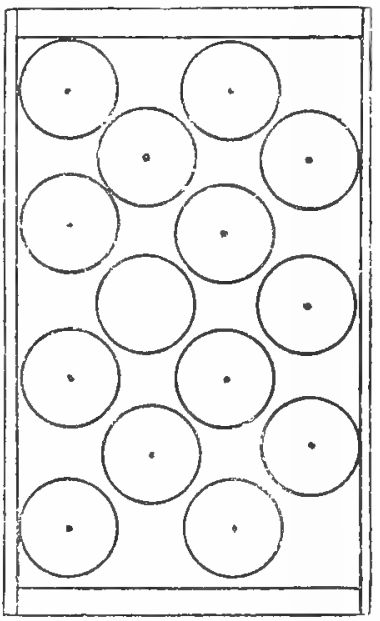

Box Containing 56 Apples. the use of the straight pack on account of the bruising of the apples. When the two sizes of boxes are used all apples may be packed diagonally. For instance, the apples that would pack straight in the special would pack diagonally in the standard. The inside measurement of the "Special" is $10 \times 11 \times 20$ inches, and of the "Standard" $10_{2}^{1} \times 11_{2}^{1} \times 18$ inches. The number of apples that can be packed in each box, according to the tier labelling, is as follows:-3-tier apples in the standard, 45 to the box; 3 -tier apples in the special, 54-63; 31-tier apples in the standard, 64, packed by the various methods herein outlined. The 4-tier straight pack requires four rows in width and four layers in depth, while the 5-tier requires five rows in width and five layers in depth. The diagonal $2 \frac{1}{2}$-tier pack is started differently. The first apple is placed in the middle of the lower end of the box, and two apples are pressed firmly in the places which are left, as shown in the illustration. In this style of pack there are two and a half rows in width and three layers in depth. This is not classed as a commercial pack, for it is only used to accommodate very 
large apples on special occasions. The

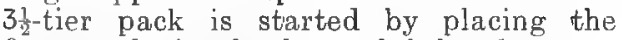
first apple in the lower left-hand corner of the box and another in the centre. Two the apples are of the same size and are being packed on the cheek, in order to obtain the proper bulge the end apples are turned with the stem ends up. Every

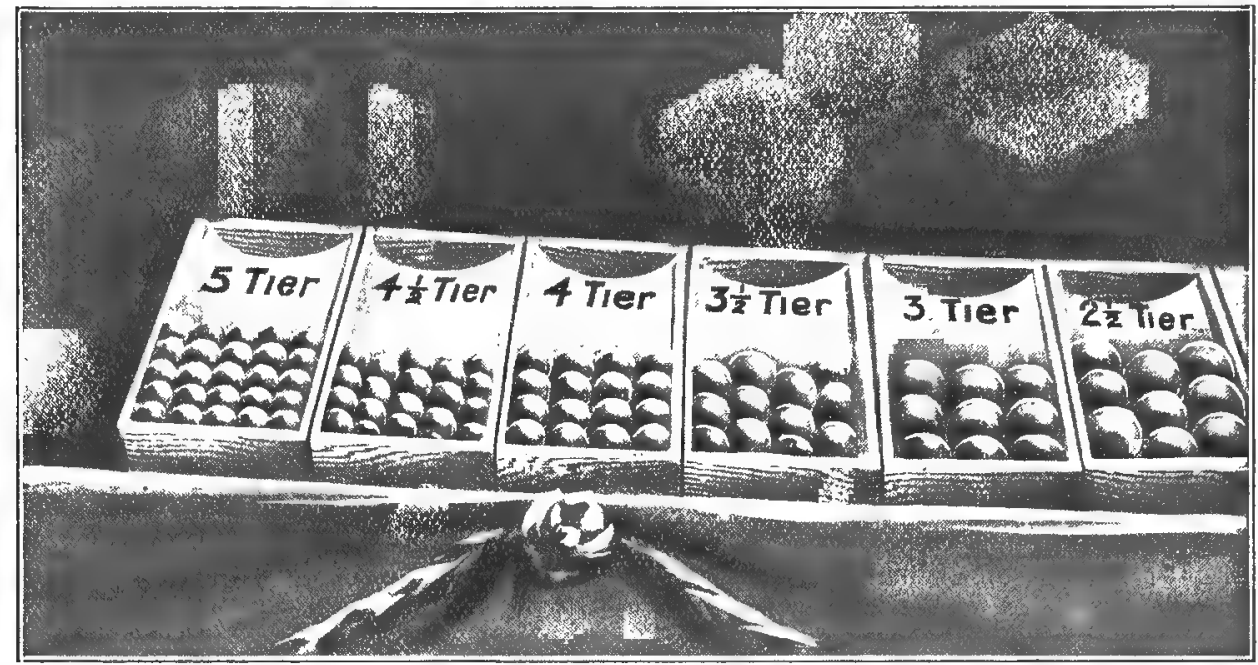

apples are then packed in the spaces which are left. The illustration shows the point very nicely. We have in this pack three and a half rows in width and four layers in depth. To start the $4 \frac{1}{2}$-tier pack the first apple is placed in the lower lefthand corner of the box, another in the lower right-hand corner, and another in the centre. Two apples are then placed firmly in the spaces that are left vacant. This pack has four and a half rows in width and five layens in depth.

"Inexperienced packers will have som" little difficulty in getting the proper bulge to the box. The illustration opposite shows a box with the bulge in the way it should appear after being nailed down. Practice, however, will obviate this. When the fruit is packed the apples at both ends should come up flush with the top. In the centre they should extend a little higher. There is more or less of a graduation between one-sized apple and another, as, for instance, between the 3 and 3s-tier apples. To obtain the proper bulge the packer selects apples that are a trifle smaller for the ends, working those that are a trifle larger to the centre. In case box should have from an inch to an inch and a half swell.

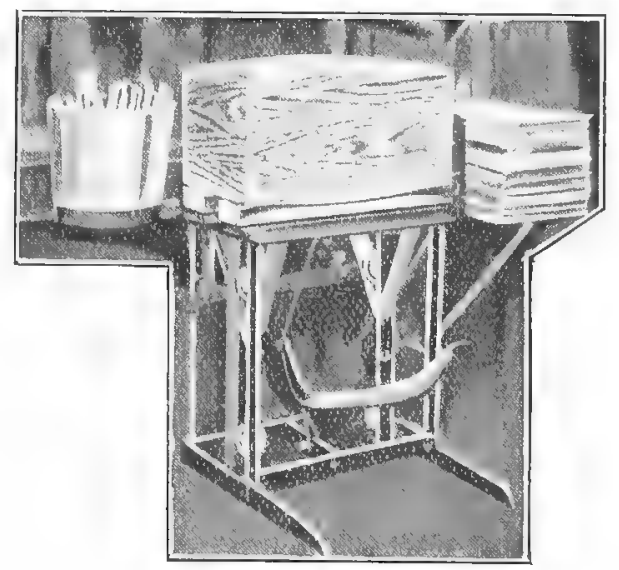

Box Press, Adjuszable to ANy Box; Rollter BEARING.

"On the end of every box a neat and attractive lithograph should be placed. This adds very much to the appearance of the box, and aids materially in selling the 
fruit. A cheap, gaudy label detracts from, rather than adds to, the appearance. A lithograph should contain the grower's name, mark or initials. On the other end of the box should be stamped the number of apples, or preferably the tier, as 4, 4흐, etc., the packer's number and the variety. This facilitates matters considerably, for the consumers know the exact number of apples."

Before the packing actually begins it is necessary to grade the fruit with accuracy and precision. A grading board or rings for the purpose is very useful. A number of excellent grading machines are now on the market, which are in every way desirable adjuncts to every well-conducted orchard. In America it is looked upon as a necessity. Again quoting Mr. C. C. Vincent, the following sizes should be taken as standards of grading:-

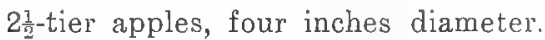

3 -tier apples $3 \frac{2}{3}$ inches diameter.

3l-tier apples, 3 1-10 inches diameter.

4-tier apples, $2 \frac{3}{4}$ inches diameter.

$4 \frac{1}{2}$-tier apples, $2 \frac{1}{2}$ inches diameter.

5-tier apples, 2 1-5 inches diameter.

Trading board for standard box:-

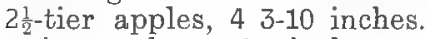

3 -tier apples, 3 4-5 inches.

3-tier apples, 3 3-10 inches.

4-tier apples, $2 \frac{7}{8}$ inches.

4.--tier apples, 2 1-5 inches.

5-tier apples, 2 inches diameter.

The work of grading being finished with, the work of placing the fruit in tiers is begun, as per illustration. That pic- ture is clear and eloquent of itself, and needs no further elucidation.

A press for packing apples in boxes is an absolute necessity. Without it the work cannot be properly done. As to which kind gives the best results, growers

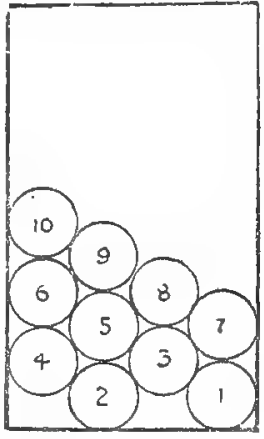

StaRting a 2.2

Diagonal Pack.

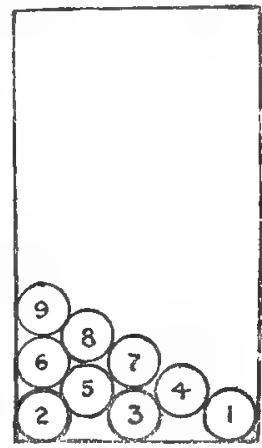

Starting a $3-2$

must learn and decide for themselves. The illustration shown is an example of one of the smaller presses used in U.S.A.

\section{Conclusion.}

Although this article has assumed greater length than was at first intended, the vast subject of, grading and packing has by no means been exhausted. Suffcient, it is hoped, has been written 10 arouse some latent interest in the work of packing, and from that beginning much gooul must inevitably result. 


\section{CHAPTER XLVII.}

\section{COST OF PREPARATION OF LAND BEHORE PLANTING AND COST OF FRUIT PLANTING.}

\section{CONSIDERATIONS.}

COST OE LABOUR.-As compared with prewar cost (say 1913), labour costs to-day nearly three times as much for the work actually accomplished because of increased wage, decreased hours and often lessened energy.

Cost of Trees, Bushes, Plan'rs,-Owing to short supply and considerable demand, these cost from three to as much as six times pre-war prices. To give one single example in the neighbourhood of Pershore, Pershore Purple Plums on Yellow Egg Plum stock sold wholesale at 7d. each before the war; the present wholesale price is $2 \mathrm{~s} .6 \mathrm{~d}$.

Dralnage.-Fruit trees need land suffiently well drained, as in waterlogged soil they do not thrive and are a certain failure; so land chosen for fruit-planting should have good, natural drainage or be efficiently artificially drained before planting. If the land is waterlogged and cannot be drained it is useless planting fruit tree's. Some established orchards would be benefited by draining if slope and outlet allowed; in this case the drains would probably be cut about $2 \mathrm{ft}$. 6ins. to $3 \mathrm{ft}$. deep down the centres of the rows between the trees 20ft. to $30 \mathrm{ft}$. apart, using 2in. drains at a cost of, say, £10 per acre. Liming, say 2 tons per acre, would be beneficial after draining, or on grassland $\frac{1}{2}$ ton of basic slag per acre improves the grass greatly.

Some of the best fruit plantations in Worcestershire (at Pershore) and in Here fordshire are drained; thus on Mr. H. S. W. Bickham's farm at Ledbury the drain pipes are laid $3 \mathrm{ft}$. deep, 24ft. apart, $2 \mathrm{in}$. drains for the herringbones and 3in. pipes for the mains. If the land is rather flat or waterlogged by springs it is better to have the main drains 4ins. diameter and the minors 3 ins. In the old days draining used to cost $£ 10$ per acre; it now costs $£ 20$ in labour alone, and a recent estimate for draining was $£ 40$ per acre. $\mathrm{Mr}$. Bickham has small brick inspection tanks to the drains, so as to be able to see whether they are working efficiently.

Cultivation.-The main cultivation will probably be done before wire fencing is erected; it is very necessary to have the land clean. In the early autumn it may be worked by steam plough with sub-soil stirring attachment, working the land 18ins, deep, then worked by cultivator. If after potatoes, the plough may be followed by a heavy horse hoe to stir the lower soil.

MaNuRing.-Fruit trees may not need manure till they commence to bear; however, if black currants and strawberres are planted with trees, these will be greatly benefited by 10 to 40 tons of farmyard manure or else shoddy or fish meal.

Headlands.-For the turning of horsedrawn implements and for carting it is necessary to leave about 10ft. round the field unplanted for a headland. If the plantation be a square block of 10 acres, with a roadway down the centre (220 yards by $10 \mathrm{ft}$. by 5), 120 perches or $\frac{3}{4}$ acre will be unplanted, or at the rate of about 12 perches or one-thirteenth of an acre per acre. It is not actually as much lost land as this, because the tree roots occupy a considerable portion of the headland.

Mr. F. Paget Norbury at Sherridge, near Malvern, has his rows of trees run diagonally to the headland, not at rightangles. He says a narrower headland is required by this arrangement, the horses moving out of the rows at a slant instead of at right-angles.

Wire Fencing.-In some districts hares and rabbits need not be protected against, being close to a village; there, however, protective fencing may be needed against boys. In most districts hares and rabbits, 
especially near woods and most particularly in time of frost and snow, are merciless on stems and boughs of young apple trees and in lesser degree to pear, plum and cherry trees. Goats, sheep, cattle and horses may damage trees. There are two methods of wire netting protection against rabbits: (a) netting each tree with a cylindrical piece of netting about $3 \mathrm{ft}$. high and 18ins, in circumference. For this purpose the trees need to have trunks clear of branches up to about $3 \mathrm{ft}$. high. One and a half 50ft. rolls of $19 \mathrm{~B} . \mathrm{W} . \mathrm{G}$. netting, $1 \frac{1}{3} \mathrm{in}$. mesh, is required, costing about $£ 3$; with labour costing about $\mathfrak{E} 1$, equals $£ 4$ per acrc for 135 trees, or $7 \mathrm{~d}$. per tree guard. (b) Other growers prefer surrounding the whole plantation with wire netting. Mr. J. W. Todman, of Borough Green, Kent, in addition to wire netting round his fruit nursery, grows each year a patch of carrots to attract hares and rabbits away from his trees in case they should get through. It is necessary to make the gateways also rabbit-proof by wire netting the gate and bringing the lowest rail close to the ground, placing a railway sleeper between the posts, sunk level with the ground.

For standard and half-standard trees in grass the wire netting guards need to be maintained for 10 or more years to protect the trees from sheep.

Eighteen gauge is often used; 17 gauge is even better, but its present cost might be prohibitive; 19 gauge is too light to be sufficiently durable for fencing purposes.

Estimated Cost of Wiring 10 Acres.The wire fencing will probably be erected shortly loefore the trees are planted. Let us suppose a square block of 10 acres is to be enclosed and that there is a roadway down the middle, necessitating a gate at each end; the following gives some idea of the requirements:-900 yards of $42 \mathrm{in}$. netting, $1 \frac{1}{2}$ in. mesh, 18 gauge (better 17), equals 18 rolls at $£ 215$ s. 5 d., $£ 49$ 17s. 6d.; thick-set barbed wire, coil wire, $281 \mathrm{bs}$. staples, $£ 310$ s.; 350 fence posts of chestnut, 4ft. 6ins. long, points dipped in creosote to $15 \mathrm{ins}$, and 33 larger posts, $8 \mathrm{ft}$. long, 4ins. dia., $£ 6$; two 9ft. gates, four gate-posts, $£ 710$ s. ; carriage and cartage of material, say $£ 32$ s. 6 d. October-Labour : erecting fence, placing 6ins, of wire netting underground, sloping outwards to check rabbits burrowing under the netting (two men about 21 days), $£ 18$. Total for 10 acres $£ 88$, or per acre $£ 816$ s.

I understand in practice the cost is about $\mathfrak{E} 10$ per acre for wire netting fence to exclude rabbit and man.

Estimated Cost of Manuring.-As strawberries and black currants are to be grown between the fruit trees, probably 10 to 40 tons farmyard manure per acr: will be used (or else shoddy or fish manure). September.-Twenty loads wellrotted yard manure at 9s. per ton, $\mathscr{E} 9$; filling and carting at 1s. 6d. per load and spreading at $6 \mathrm{~d}$. per load, \&2. Total, $£ 11$. A heavier dressing would be better if obtainable and the cost could be afforded.

Cultivations Before Planting. October.-Steam ploughing with subsoiler attachment $£ 310$ s., coal and water 10 s., \&4; - or, if after potatoes, ploughing (one man and two horses), $£ 1$ 12s. 6d.; each turrow followed by a heavy horse hive (rne man and two horses), £1 12s. 6d.-two heavy harrowings at $3 \mathrm{~s} 6 \mathrm{~d}$, $7 \mathrm{~s}$. ; two light harrowings at $2 \mathrm{~s} .9 \mathrm{~d} ., 5 \mathrm{~s}$. $6 \mathrm{~d}$.; rolling, if for strawberries, 3s. 6d.; collecting and clearing weeds, $£ 1$. Total, $£ 516$ s.

Cost of Fruix Trees and Bushes.- 135 bush apple (Bramley, Lane, Lord Derby, Worcester, Allington, Beauty of Bath), two-year old trees at $£ 20$ per 100 , $£ 27$; (one-year olds at $£ 12$ 10s. per 100, £16 18s.). Note.-Half-standard or standard trees might be planted at $24 \mathrm{ft}$. or $30 \mathrm{ft}$. respectively as permanent plants.-1,075 black currant bushes (say Baldwin), twoyear old bushes at $£ 20$ per $1,000, £ 2110$ s. (one-year plants at $£ 10$ per $1,000, £ 10$ 15s.). Total, £48 10s. per acre.

If one-year-old trees and bushes are purchased (costing, say, $£ 27$ 13s.) instead of two year olds (costing, say, £48 10s.) the initial cost is less, but the two year olds are nevertheless recommended as being actually more economical, as saving one year's cultivation, rent, etc.

Planting Trees and Bushes.-November.-Setting out for planting, 10s. ; digging holes for bush apples 18ft. apart, for black currants $6 \mathrm{ft}$. apart, and planting, £4. Total, £4 10s. pel acre.

Plant different varieties of apples row by row to equalise growth and for better cross-pollination.

An experienced grower wrote me that 
he would rather have black currants alone without strawberries. However, for the sake of quicker return, the approximate cost of strawberry planting is here given.

Cultivations after Planting and Cost of Planting Strawberries.-FebruarySix harrowings (two men and one horse) at $7 \mathrm{~s}$. each harrowing, £2 2s. March.12,000 strawberry runners (Royal Sovereign) at £1 per 1,000, £12; planting strawberries $3 \mathrm{ft}$. by 16 ins. at 4s. per 1,000, £2 8s. April to September.-Six cultivations with Planet Junior (two men and one horse) at 9s. 8d. each time, £2 18s.; hand hoeing during season, $£ 6$; cutting runners during season, 21 10s. Total, £26 18s. per acre.

Spraying Young Apple Trees.-March. -Lime spray (once). May and July.Caterpillar sprays (twice). Labour 3s.6d., material 1s. $6 \mathrm{~d}$, each time, $15 \mathrm{~s}$. per acre.

It is a good plan to put a little dung as a mulch round young apple trees in the spring in case of a drought the first year.

Rent, Rates and TaXes for One Year.Say net rent $£ 2$, tithe $2 \mathrm{~s}$. $6 \mathrm{~d}$., land tax 2s. 6 d., rates $15 \mathrm{~s}$., income tax 10s. per acre. Total, £3 10s.

Strawberries should pay expenses their second year. If these are not grown, gooseberries and currants should pay expenses their third or fourth year, whilst the trees would become profitable in their eighth to tenth year. Mr. E. M. Bear, of Hailsham, Sussex, from his experience considers it now requires at least $£ 30$ per acre capital to work ready planted fruit land, but that the fruit farmer should have more capital than this for fear of his first season proving unfavourable. Mr. H. S. Bickham, of Hilltop, Ledbury, Herefordshire, finds it now costs him $£ 70$ per acre annual expenditure on his established fruit plantations. His plantations are extremely well cultivated, manured and sprayed, but they yield wonderful crops.

Summary of Approximate Capital EXPENDITURE.

If land is purchased the price per acre for unplanted land may vary from £25 up to $£ 100$ per acre, the latter for best land in a successful fruit-growing district. The purchase price of land is about 25 times its agricultural rent.

Drainage, if necessary, may cost $£ 40$ per acre if well done.
Fencing against rabbits and man, if necessary, may cost $£ 10$ per acre for, say, 10 acres; less for more, greater cost if for less.

Manuring may cost from £5 (for bone meal placed in holes) up to £25 per acresay £11. Under some circumstances manuring may not be needed; even then a mulch over the tree roots will be advantageous.

Cultivation before planting, £5 16s.; cost of trees and bushes, £48 10s.; planting trees and bushes, $£ 410 \mathrm{~s}$. ; cultivation after planting, planting strawberries, cultivation to Michaelmas, $£ 26$ 18s. (if no strawberries, say $£ 11$ ); spraying young apple trees, 15s.; share in making roads, packing-shed, \&c., £3; replacing dead trees, bushes or strawberry plants, 22 ; expenses of cultivation, \&c., till strawberries crop in second year, 225 ; superintendence from commencement, $£ 5$; interest on capital for two years at 6 per cent., £12; rent, \&c., for two years at $£ 3$ 10s., £7. Total, £140 9s.

So with cost of fencing it looks like $£ 150$, with any manuring to add. If the owner himself does much of the labour of course the expenditure in labour is greatly lessened.

The following gives an idea of wholesale prices of fruit trees and bushes of good quality of ordinary good varieties for planting in season 1920-21:-Bush apple trees, one-year old on Paradise or Crab, selected $£ 12$ 10s., good $£ 10$, two-year old $£ 20$ per 100; pear and plum trees, same prices as apple trees; crab-apple stocks, budding size, $£ 310$ s. per 100 ; black currant bushes, one-year old $£ 8$ to $£ 12$, two-year old $£ 20$, cuttings $£ 3$ to $£ 310$ s. per 1,000 ; red currant bushes, one-year old $£ 710$ s., two-year old $£ 15$, cuttings $15 \mathrm{~s}$. to $£ 1$ per 1,000 ; gooseberry bushes, one-year old $£ 20$, two-year old £30 per 1,000 ; raspberries, $£ 1$ to $£ 15$ s. per 1,000 up to $£ 310$ s. for new-quality sorts; strawberry plants, ordinary varieties, good runners from one and two year old plants, 15s. to 20s. per 1,000; rhubarb plants, 10s. per 100.

Approximate Present Cost of Farm OpERATIONS.

(From "The Agriculturist's Diary" for 1921.)

Plovghing by motor tractor, 3ins. deep, 22s. per acre; 6ins. deep, 25s.; by one mun 
and two horses ( $\frac{3}{4}$ to 1 acre per day), 20s. to $25 \mathrm{~s}$; ; by one man, one boy and three horses, 30s. to 40s.; by steam with two engines, 6ins. to 8ins. deep (8 acres per day), 14s. to 20s., plus cost of coal and water and cartage of same.

Cultivating by steam (30 to 50 acres per day), once over, 14s. to 20 s.; twice over, $24 \mathrm{~s}$. to 30 s., plus coal, water and cartage.

Drag Harrowing by steam (30 to 50 acres per day), once over, 8s. ; twice over, 14s, plus cost of coal and water' by two horses ( 7 to 9 acres per day), $2 \mathrm{~s}$. $6 \mathrm{~d}$. to $3 \mathrm{~s}$; ; by three horses (8 to 10 acres per day), $4 \mathrm{~s}$, to $6 \mathrm{~s}$.

ZIG-ZAG Harrowing, two horses (10 to 12 acres per day), 1s. 6d. to 2s. ; seed has rows, one horse (12 to 14 acres per day), 1s. to $1 \mathrm{~s}$. $4 \mathrm{~d}$.

Rolling, Cambridge, with three horses (7 to 10 acres per day), 2s. 8d.; two-horse roll, $6 \mathrm{ft}$. wide (8 to 12 acres per day), 1s. $6 \mathrm{~d}$. to $2 \mathrm{~s}$.; one-horse roll, $5 \mathrm{ft}$. wide (8 acres per day), 1s. 4 d.

ManuRING.--Dung carting, 2s. per ton per mile; dung spreading, 4d. per load; is. to $4 \mathrm{~s}$. per score loads.

Sowing Artificial Manure Broadcast, at rate of $5 \mathrm{cwts}$. per acre, $5 \mathrm{~s}$. per ton; sowing soot broadcast, $1 \frac{1}{2} d$. per bushel, 10s. per 100 bushels.

.'PREADING LiMe, 9d. per ton, eight tons spread per day.

Horse Hoeing, one man, one boy and one horse ( 3 to 5 acres per day), $3 \mathrm{~s}$, to $4 \mathrm{~s}$.

HaND Hoeing. - Flat hoeing cabbage set out, 10s. to $12 \mathrm{~s}$.; singling turnips, 10s. to $12 \mathrm{~s}$.

Planting C4beage, 1 s. 4 l. per 1,000, or. according to distance, per acre 16s. to $24 \mathrm{~s}$.

Hedge Laying, 1s. to 1s. 4d. per pole, 5s. per chain.

Field Gate Hanging, 10s. each.

FAGGOTING, 8s. per 120; making faggots, 1s. per score.

Double Digaing or bastard trenching, 1s. to 1s. 3 d. per rod, $£ 8$ to $£ 10$ per acre. Cost of Horse Labour.-From careful account-keeping at Wye Agricultural C'nIlege the present cost of horse labour is found to be about $5 \mathrm{~s}$. 6d. per day.

Prices Paid for Piece-work on Fruit Farms around Maidstone (1920-21).

In setting piece-work prices it is generally reckoned that a man should ear'n a quarter more money than for day-work.

DigGING light land, 50s.; medium, 55s.; heavy, 60s. per acre.

HAND HoEING all ground, 12s. to $15 \mathrm{~s}$. per acre. Hand hoeing a crop after horse hoeing, if weedy, 10s. to 15s. per acre.

DIGGING HOLES for trees, 3ft. by $3 \mathrm{ft}$, 18ins. deep, 2d. to $4 \mathrm{~d}$. per hole; $5 \mathrm{ft}$. by $5 \mathrm{ft}$., 18ins. deep, $4 d$. to $6 \mathrm{~d}$. per hole. Digging holes for gooseberries and the like, 1s. 6d. to $2 \mathrm{~s}$. per 100.

Mowing Grass by hand, 15s. to 25s. per acre.

HEDGe BRUSHING, 4d. per rod if 5ft. high. Pruning Gooseberry Bushes, 7s. 6d. per 100.

Cutting Strawberry Runners, 12s. per acre.

LitTering Strawberries, 12s. per acre. Grafting young stocks, 7s. per 100. Crown grafting old trees, $8 \mathrm{~s}$. to $10 \mathrm{~s}$. per 100.

BUdDing, 2s. 6d. per 100.

PIĆING apples, not generally done piece-work, but, if heavy, sometimes at $3 \mathrm{~d}$. to $5 \mathrm{~d}$. per bushel; plums, $2 \mathrm{~d}$. to $4 \mathrm{~d}$. per half-bushel; damsons, 9d. to 1s. 6d.: cherries, 1s. $6 \mathrm{~d}$. to $2 \mathrm{~s}$.; gooseberries, 9d to 1s.; red currants, 1s. to 1s. 6d.; black currants 2s. 6d. to 4s.; strawberries, 1s. to 1s. 6d. per peck (12lbs.); raspberries, 1 d. to $3 d$. per lb.; nuts, 3d, per 100lbs.

\section{Legal Expenses.}

Preparing and Completing a Lease, $7 \frac{1}{2}$ per cent. up to $£ 100$ rent, 50 s. on each complete $£ 100$ over $£ 500$; over $£ 500$, £1 per $£ 100$; minimum charge, £5. Arrangement for smaller fees can be made previous to commencing the work. The tenant usually has to nay for the lease. 


\section{CHAPTER YIVIII.}

\section{LAND MEASUREMENT AND SURVEYING IN RELATION TO FRUIT GROWING.}

By A. H. HaINes, P.A.S.I., Estate Management Department, The Agricultural College, Wye, Kent.

It is indisputable that every one in any way connected with land should be able to ascertain the area of any portion thereof if required, and consequently a few notes on the subject may be of help.

First of all we must enquire into what equipment is necessary for the work. In doing so we must not lose sight of the fact chain of 100 links (66 feet), and 10 arrows or pins for marking distances. Such a chain will cost from $7 / 6$ to $20 /$-, according to whether it is made of best cut steel wire or of iron. A lightish chain of not more than, say, 5lbs., will be found best.

If it be preferred to use a foot chain (this unit of measurement being perhaps.

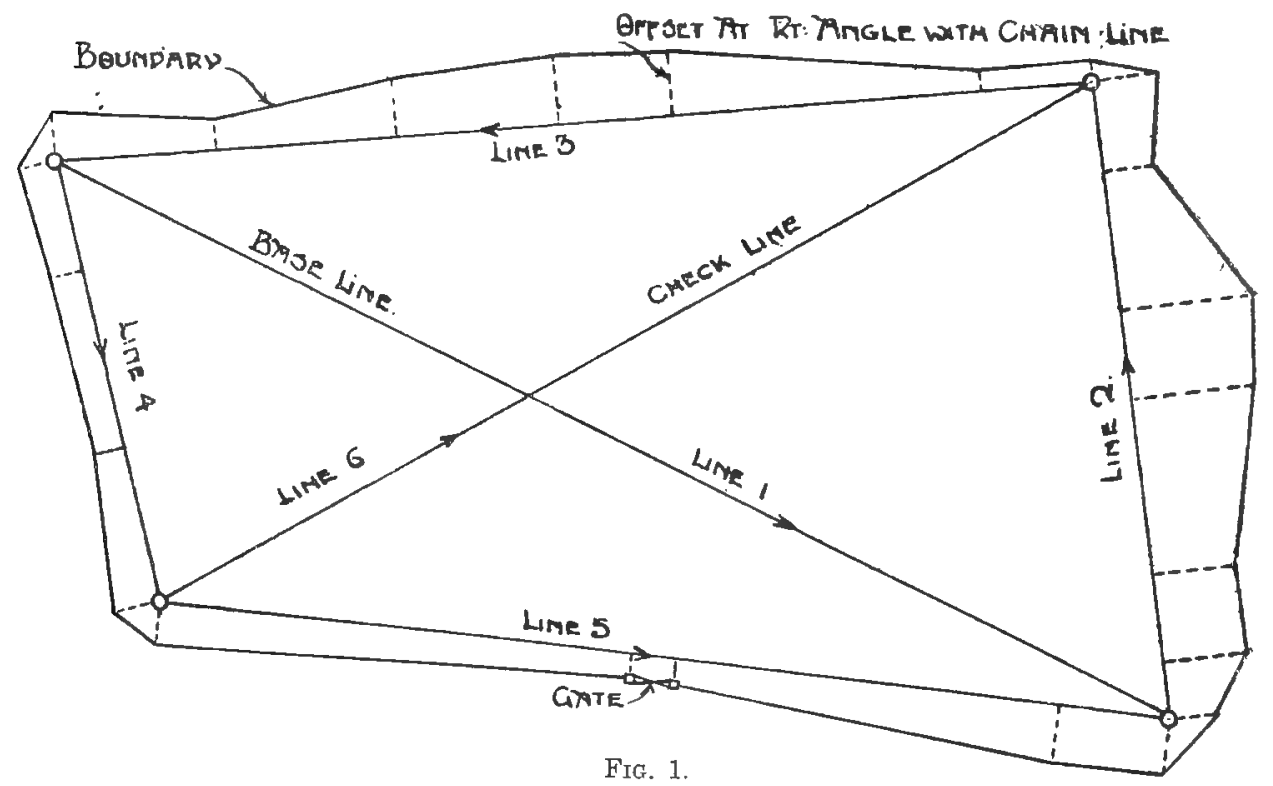

that this branch of the work is only a side issue in the profession of fruit-growing, and therefore any considerable outlay of money in apparatus, such as would be used by a surveyor, is not warranted. It will suffice if the fruit grower buys only a $\frac{1}{500}$ boxwood scale, a Gunter's land better understood than the link), it would cost a little more on account of its greater length. But the writer recommends that the first-mentioned land chain should be used for various reasons, not the least of which is the greater facility afforded in the calculation of the area after measurement. 
When the area has been measured the reduction to acres, roods and perches is very simple by this means.

Suppose a rectangular plot of land, whose length is 27 chains 63 links, and breadth 21 chains 10 links. Then

$$
\begin{aligned}
& \left.\begin{array}{l}
27 \cdot 63 \\
21 \cdot 10
\end{array}\right\} \text { multiply } \\
& \begin{array}{c}
27630 \\
2763
\end{array} \\
& \frac{5526}{5829930}
\end{aligned}
$$

It is only necessary to move the decimal point five places to the left to bring it to acres, there being 100,000 square links in obtain one from Messrs. Edward Stanford, 12, 13, and 14, Long Acre, W.C.

The rest of the outdoor equipment may be made at home and should consist of :-

1. Some straight ash poles 6 to 8 feet long, with a piece of white calico nailed to the top to render them more visible, and pointed at the bottom for insertion in the ground.

2. Some small pegs about one foot in length, pointed at one end and, say, two inches square at the other.

3. One ash pole of ten links in length, each link being marked off thereon, for taking offsets and called an offset pole. An ordinary tape might be used instead.

4. A note book into which to enter measurements.

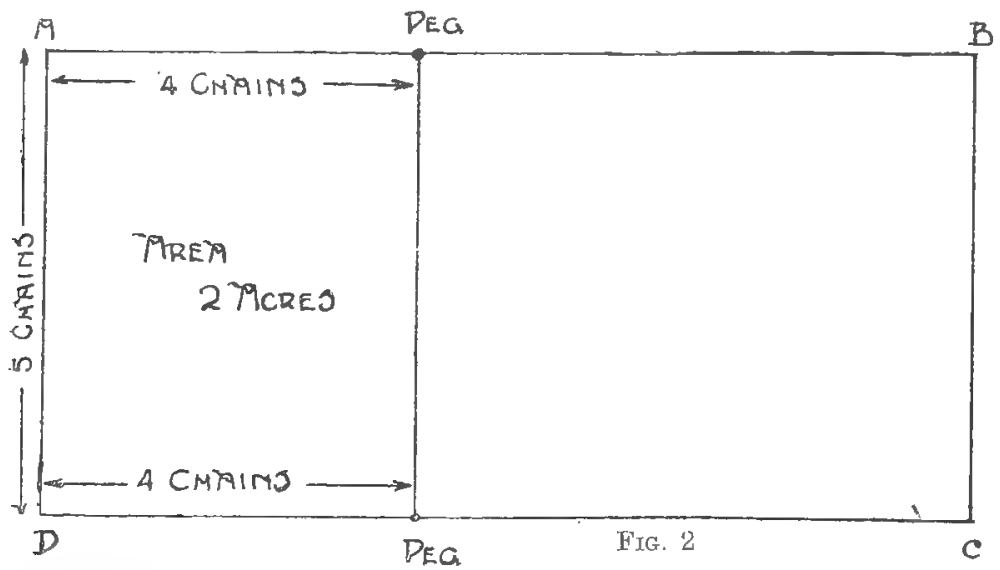

one acre. 58.29930 acres. Multiply the decimals by 4 and 40 respectively, and we get roods and perches, thus

$$
\begin{aligned}
& 29930 \\
& 4 \\
& \overline{1 \cdot 19720}=1 \mathrm{rood} \\
& 40 \\
& \cdot 7 \cdot 88800=7 \text { perches }
\end{aligned}
$$

The answer is therefore 58ac. 1rd. 7p.

Compare this with the working required if the foot chain is used and the advantage is apparent.

The writer has not included in the outlay an ordnance map to the scale of $25^{1} \overline{0}$, presuming that every fruit-grower would have such a plan. If he has not he should
5. A cross staff. This instrument is for setting out rıght angles, and may be manufactured by cutting a straight pole 5 feet in length and sharpening the bottom of it for insertion in the ground. On the top of this pole attach firmly, so as to form a small table, a piece of wood which has been cut square and has two saw cuts $\frac{1}{8}$ in. deep at right angles to one another, thus-

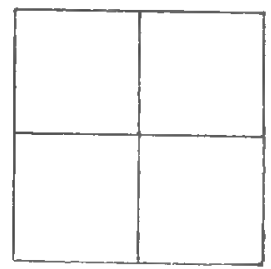


It is obvious, then, that if such an instrument be sighted along one saw cut exactly in line with two poles, by looking along the other saw cut a perpendicular may be set off or obtained.

6. An ordinary compass for obtaining the aspect.

7. A bundle of laths for lining out.

With this equipment we are in a position to consider the three propositions which are most likely to present them. selves. They are as follows:-

(i) To make a plan of a small area to scale.

(ii) To find the area of a given plot or field.

(iii) To subdivide areas into any required size.

(i) To Mare a Plan of a Small Area to Scale.

Before starting be sure to see that the chain in use is correct. If the measurements be made with a stretched chain the
Fig, 1 gives an idea of the method of procedure:-

$O$ indicates the position of the ash poles and the chain lines are measured successively $1,2,3$, etc., as indicated in the sketch. Offset,s are measured from the chain lines to the boundary where shown. An extra line, called the check line, is measured, which, when the plan has been drawn on paper, should exactly fit in, and thus prove the accuracy of the work.

A specimen of entry into the Field or Note-book is as follows:-

Chain line.

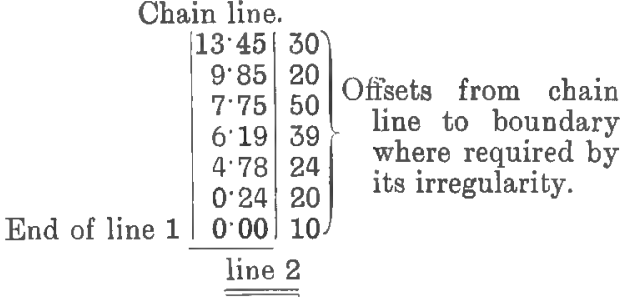

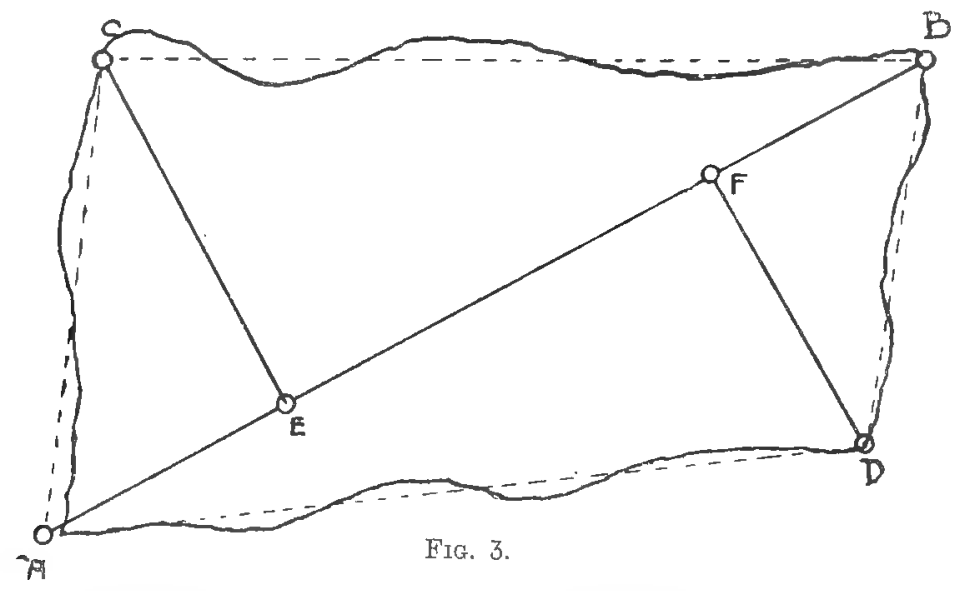

result is worthless unless the area be mathematically adjusted afterwards-a contingency better avoided.

Next bear in mind that the basis of all measurement of area is the triangle, because it is the only geometrical figure which cannot change its shape without at the same time altering the length of its sides. Consequently, if we ascertain the length of the sides by measurement, its shape and size are determinate.
The figures in blacker type represent the position of the poles or stations as they are called.

An exact plan can be drawn to scale from such field work. The correct area may be obtained with the scale, by first calculating the areas of the two main triangles and then adding the offsetted areas which are made into trapezoids and triangles and calculated accordingly. 
(ii) To Find the Area of a Given Plot OR FIELD.

This is simple. Fig. 3 gives the idea:Run a line A B diagonally across the field and on this line measure two perpendiculars, found by means of the cross-staff, to the other corners of the field C and D. Sufficient data has then been obtained. $\mathrm{A} B$ multiplied by $\mathrm{C} \mathrm{E}$ divided by 2 gives us the area of that side of the field, and $\mathrm{A} B \times \mathrm{F} D$ divided by 2 gives us the area of the other side. Note that when the field is bounded by irregular fences the lines must be laid down on a give and take principle. The result, of course, in this case is not so accurate as in example No. 1 but it is sufficiently accurate when only an to A D. Suppose the fence A D to be 5 chains long.

Divide the required area by $\mathrm{A} D$ and we get the length of the sides to be measured along $\mathrm{A} \mathrm{B}$ and $\mathrm{D} \mathrm{C}$.

5 chains $=500$ links.

2 acres $=200,000$ square links.

Then $200,000 \div 500=400$ links, i.e., 4 chains. Measure off along A B and D C 4 chains and put in pegs. A fence erected between these pegs will cut off an area equal to 2 acres as required.

\section{Example II. (Fig. 4).}

When the plot of land has irregular boundaries the procedure is somewhat similar, but first of all the irregular boun-

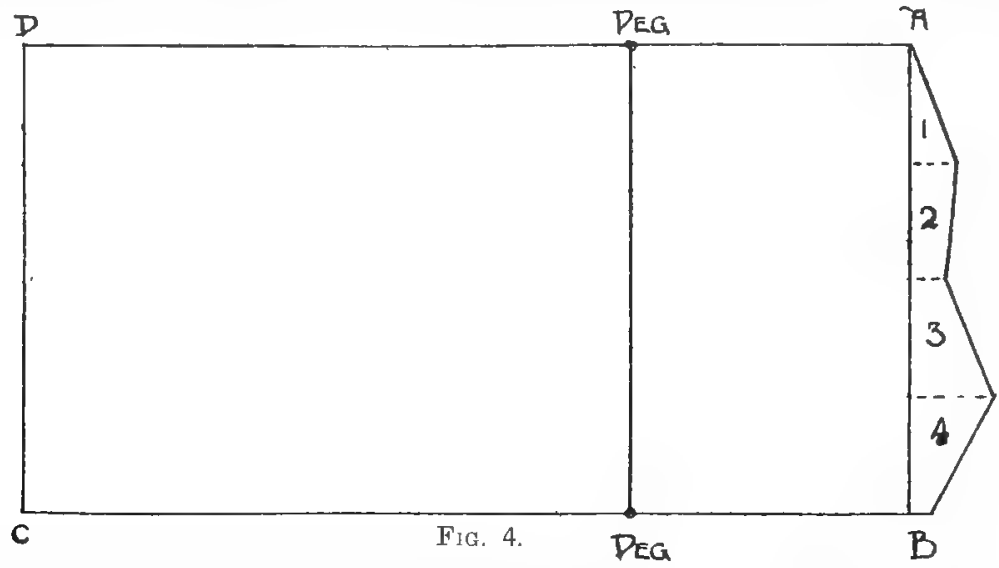

approximate idea. of the acreage is required.

\section{(iii) To Sub-Divide Areas into any Required Size.}

Before actually setting out the work in the field and measuring the distances for the purpose of sub-dividing areas, laying out plots, etc., a tracing of the area to be divided should be taken from the ordnance map. On this tracing the subdivision should be worked out, and the actual measurements in the field made from it.

The easiest case of sub-division is that of a rectangular plot.

\section{Example I. (Fig. 2).}

A B C D is the given plot: it is required to cut off 2 acres by a line running parallel daries must be straightened. If we take an example where one of the sides of the field is crooked and the other two are straight and parallel, it will serve to show the method to be adopted.

A B C D is the given field : it is required to cut off a plot equal to 2 acres by a line running from the side $A \mathrm{D}$ to the side $\mathrm{B} C$. On the tracing draw a line joining $\mathrm{A} B$, and work out the area of the piece of land thus cut off between it and the curved boundary The piece marked No. 1 is worked out according to the rule for triangles and the pieces 2,3 , and 4 according to the rule for trapezoids. Suppose this area already cut off equals 10,000 square links, then the area which remains still to be cut off to complete the 2 acres is 200,000 less 10,000 - that is, 190,000 square links. 
Proceed as before. Divide 190,000 by the length of A B which we will suppose is 5 chains (500 links). $190,000 \div 500=3.80$ chains ( 3 chains 80 links). Measure off along A D and B C a distance of 3.80 chains and put in pegs as before in the field.

The point to be borne in mind in this kind of work is that the area must be worked out on the plan before any pegging out of measurements in the field.

Before closing this short article it may be worth while considering the measurement of an area which it is impossible to see across on account of fruit trees or other obstruction to sight. Take as an example the orchard, Fig. 6

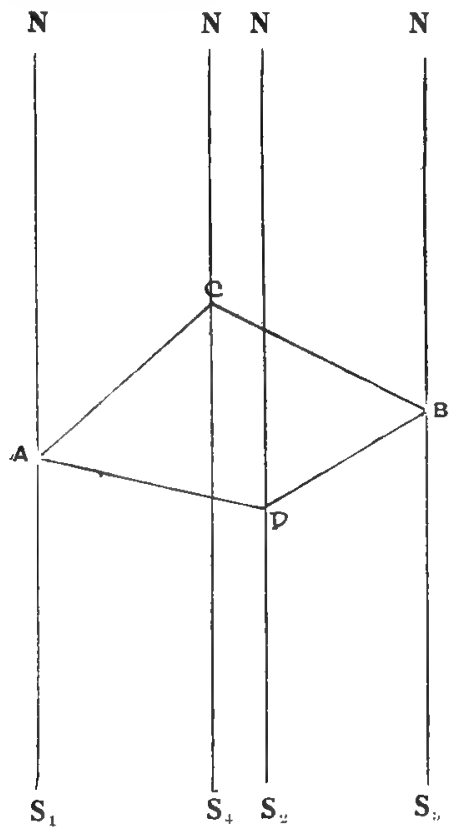

Frg. 5.
It is impossible to see from pole $A$ to pole $B$ on account of the trees. Try first, if it is possible to see both poles from an intermediate point between them in the middle of the orchard. It is often the case, when one cannot see from one point to the other, that both poles are visible from a middle point. If this is so then find the exact point in line by aid of the cross staff and put in a pole at this point. Now proceed to chain from $A$ to this intermediate point and then on to B and lay out the figure in triangles as before explained.

Should this method fail nothing is left but to measure round the area as follows. Measure from $A$ to $D$, and take the bearing of the line with a compass, then from $\mathrm{D}$ to $\mathrm{B}, \mathrm{B}$ to $\mathrm{C}, \mathrm{C}$ to $\mathrm{A}$, taking the bearing in each case. (See Fig. 5.)

Now draw on paper a line N S to indicate the direction of North. Draw A D to scale from a point midway in this line bearing the number of degrees ascertained for it by the compass (say $120 \mathrm{deg}$.). Draw parallel to $\mathrm{N} \mathrm{S}_{1}$ another line $\mathrm{NS}_{2}$ and from the point $\mathrm{D}$ draw $\mathrm{DB}$ to scale bearing the number of degrees ascertained for it by the compass (say $80 \mathrm{deg}$.).

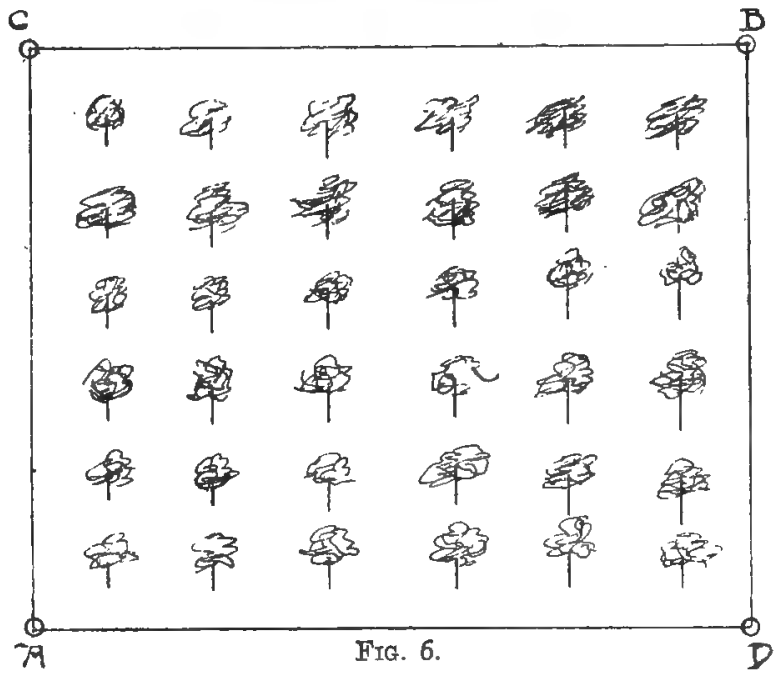

Proceed with the remaining lines as described, and the proof of correct reading of the angles lies in the fact that $\mathrm{C} \mathrm{A}$ will close on the point $A$. This rarely occurs exactly, an adjustment is then made.

Full explanations and various cases are given in the writer's book on "Land Surveying and Building Construction," by A. H. Harnes and A. F. Hood DANiel, published by Messrs. Longmans. 


\section{CHAPTER XLIX.}

\section{BOOK-KEEPING FOR FRUIT FARMERS, MARIET GARDENERS AND SMALL-HOLDERS.}

By H. W. Kersay, Lecturer at the South-Eastern Agriculturai College, Wye, and at the Horticultural College, Swanley.

The importance of a knowledge of bookkeeping by business men was never more urgent than at the present time. Fruitgrowers, market-gardeners and others engaged in similar occupations should be able to keep a strict account of their receipts and expenditure.

The cost of production has increased to such an extent that it is only by the closest attention to details and the cutting down of unnecessary expenses that an adequate profit can be made on the capital invested in the business. It is essential that all expenditure should be carefully checked and that the receipts for the various crops should be commensurate with the wages, manures and rent, rates and taxes, which are the main items of expenditure, that have been incurred in their production.

It is also important in these days of high taxation to be able to put before the Income Tax authorities a clear statement of accounts in the event of the profits being less than the amount for which growers have been assessed, in order to be in a position to make a claim for repayment.

No business can be run satisfactorily unless careful accounts are kept, and the simpler the method the better. The

RECEIPTS. writer claims that the system of bookkeeping as set out in this article not only insures accuracy and simplicity, but is also sufficient for the requirements of the Income Tax Authorities, should a claim for repayment have to be made.

\section{The Cash Analysis System.}

(A simple method of Double Entry).

The book required for the purpose is a cash book provided with analysis columns, ruled for $£$. $s$. d., in addition to the ordinary cash columns on both receipt and payments sides.

For a fruit grower the headings of these analysis columns on the Receipt side might be as follows:-Apples, Pears, Plums, Currants, Gooseberries, Strawberries, and on the Payment side:-Wages, Manures. Rent, Rates and Taxes, Tradesmen's Bills, etc. When a sale is made and cash is received the entry is made in the cash column in the usual way, and also in one of the analysis columns.

For example, 20 sieves of Bramleys are consigned to F. Jenkins, Covent Garden, who sends in return a cheque for $£ 10$ $15 \mathrm{~s}$. 9d, after deducting the usual commission and charges. A cheque is received for $£ 510 \mathrm{~s}$. Od., from F. Jones, for vegetables. The entries would be as follows:-

AnaLysis of Receipts.

\begin{tabular}{|c|c|c|c|c|c|c|c|}
\hline & & & 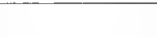 & & & & \\
\hline Date. & Name. & Casb. & Apples. & Plums. & G. berries. & Str-berries & Vegetables. \\
\hline $\begin{array}{r}1920 . \\
\text { Dec. } 1 \\
" \quad 2\end{array}$ & $\begin{array}{l}\text { To F. Jenkins } \\
\text { "F. Jones }\end{array}$ & $\begin{array}{rrr}\boldsymbol{s} & \mathrm{s} . & \mathrm{d} \\
10 & 15 & 9 \\
5 & 10 & 0\end{array}$ & $\begin{array}{rrr}\text { f } & \text { s. } & \text { d. } \\
10 & 15 & 9\end{array}$ & $f$ s. d. & $£$ s. $d$. & $\begin{array}{lll}\text { s } & \text { s. } & \text { d. }\end{array}$ & $\begin{array}{ccc}\qquad & \text { s. } & \text { d. } \\
5 & 10 & 0\end{array}$ \\
\hline
\end{tabular}


Similarly a payment for wages would be entered on the Payment side in the cash column and in the "Wages" analysis column.

At the bottom of each page all the columns are added up. As for every entry in the cash column there is a corresponding entry in the analysis column, it is clear that if the accounts have been kept accurately the total of the CAsH columns must equal the total of the ANALYsIs columns and the totals should not be carried forward to the top of the next page until these figures agree. In this way a check is kept on the accuracy of the entries throughout the year.

At the end of the year the receipts for all sales of Apples, Plums, Currants, etc, will be shown, and on the payment side the total expenditure for Wages, Manures, Rent, Rates and Taxes, etc.

We will say, for example, that the receipts and payments have been as follows :-

\section{RECFIPTS.}

Apples and pears $£$ s. d.

Plums $250 \quad 0 \quad 0$

Gooseberries $100 \quad 0 \quad 0$

Vegetables

$\begin{array}{lll}50 & 0 & 0\end{array}$

Sundry receipts

80000

1000

\section{Paymexts.}

Wages $£$ s. d.

Manures $\begin{array}{lll}180 & 0 & 0\end{array}$

Rent, rates and taxes

$90 \quad 0 \quad 0$

80000

Tradesmen's bills

Sundry payments

$\begin{array}{lll}50 & 0 & 0\end{array}$

$\begin{array}{lll}15 & 0 & 0\end{array}$

This leaves a balance of receipts in excess of payments of $£ 75$. In order, however, to obtain the actual results of the year's transactions and to arrive at the profit or loss the following items must be included :-

(a) The valuations at the beginning and at the end of the year.

(b) The debts owing to and by the business.

(c) The produce from the farm consumed in the house during the year.

(a) The valuation at the beginning of the year must be entered on the Payment side, and that at the end of the year on the Receipt side. (b) The debts owing to the business may be taken either from the Invoice Book, an example of which is shown below, or from the Ledger, if such a book is kept. The amount must be entered on the receipt side.

The unpaid bills will provide the amount owing by the business, which amount must be entered on the Payment side.

(c) The produce consumed in the house should be entered daily throughout the year in a book provided for the purpose, and valued at market price, less the expenses of marketing, and the amount must be entered on the Receipt side. (Note.This information is required by the Income Tax authorities).

The statement of accounts for the year will then be as follows :-

\section{INCOME.}

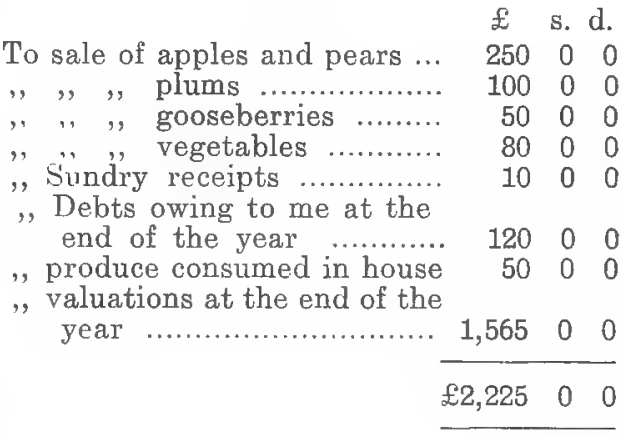

\section{EIPENDITURE.}

By wages .......................... $180 \quad 0 \quad 0$

,, manures ....................... $90 \quad 0 \quad 0$

", rent, rates and taxes ......... $\quad 80 \quad 000$

,, tradesmen's bills .............. $50 \quad 0 \quad 0$

,, sundry payments ............. $15 \quad 0 \quad 0$

,, unpaid bills at the end of

the year

,, valuations at the begining

of the year

$40 \quad 0 \quad 0$

Balance, profit

$1,490 \quad 0 \quad 0$

$280 \quad 0 \quad 0$

$£ 2,225 \quad 0 \quad 0$

As will be seen by the above statement a profit of $£ 280$ is the result of the year's trading. Such a statement is all that is required for claiming repayment of Income Tax. 
Further information with regard to the Cash Analysis system can be obtained in "A Simple method of Book-keeping for Farmers, Smallholders, etc.," by H. W. Kersey, published by Headley Bros., Printers, Ashford, Kent, Price 3s, 6d.

In addition to the Cash Analysis book there should be: (a) A Sales-book; (b) a Manifold Invoice-book; and (c) an Analysed-Wages book. A Ledger for personal accounts is also advisable, but is not absolutely necessary.

(a) Sales-book. In this book each day's sales, with full particulars, should be entered, namely date, produce, purchaser, price.

(b) Manifold Invoice-book. An invoice should be sent with each consignment, and when written in duplicate or triplicate by means of a carbon sheet, full details of the consignment are always at hand when reference is required. One invoice is sent with the goods, the second by post to the purchaser, and the third remains in the book.

Form of Invoice.

Date......19

From .................... To.....................

........................... Market
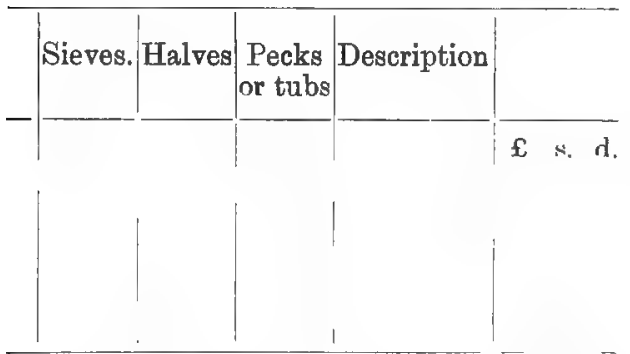

If no Ledger is kept then, as each account is settled, the word "paid " and the date of payment should be written in the Sale-book or Invoice-book.

(c) Analysed Wages-book. This form of wages-book will give much more useful information than the form of wages-book which is generally in use. Most businesses can be divided into different departments. For example, in the case of a Fruit Farm, as follows:-Plantation No. 1, Plantation No. 2, Market-garden, Glasshouses. The wages-book is ruled in a similar way to the Cash Analysis book, and the above headings would be used; as the wages are paid each week they would be charged to their respective departments as shown above.

Each week the totals are carried to a page at the end of the Wages-book and are entered in similar analysis columns, so that at the end of the year the total expenditure in wages in each department can be ascertained.

The system of "Costs Accounting" has been advocated lately in many quarters, and there is no doubt that, provided a sufficient amount of time can be given to these acounts, the information to be obtained in keeping them by this method is invaluable. If any fruit-grower intends adopting this system it appears to the writer that the best plan would be to divide the farm into 3-acre, 4-acre or 5-acre plots, according to the size of the holding or into sections according to the various croppings, and to have the following headings in the Analysis Cash-book on both Receipt and Payment sides:-Plantation No. 1, Plantation No. 2, Marketgarden, Glasshouses, etc.

All the sales of fruit, both hard and soft, from Plantation No. 1 would be entered in that column, and similarly all the expenses incurred in the cultivations, etc., of Plantation No. 1 would be entered in a similar column on the payment side, such as wages, manures, rent, rates and taxes, tradesmen's bills, etc. The cost of manures applied to each section would be a comparatively easy matter to arrive at, and the wages would create no difficulty, as the wages-book would have columns similar to the Cash-book, and the amounts would be entered weekly under each section.

The rent and tradesmen's bills would, however, have to be carefully apportioned and such items as horse-labour, upkeep of roads, trimming of fences, depreciation of implements and tools, and repairs to buildings would require a considerable amount of time and care.

There would also be the valuation of each separate section to be dealt with at the beginning and end of the year.

A thorough knowledge of book-keeping would be necessary, but the difficulties are not insuperable, and the accounts 
would clearly show at the end of the year chased. 3. Manures. 4. Hay, Straw, which section and which system of Feeding Stuffs. 5. Bushes, Trees, Plants, cropping was the most profitable.

Mr. Geoffrey F. Hooper, from his experience on his fruit farm, finds the following useful as headings in his Cashbook:-

ReCEIPTs.-1. Total. 2. Fruit Sales. 3. Live Stock Sold. 4. Hay and Straw Sold. 5. Vegetable Sales. 6. Sundries. Seeds. 6. Wages. 7. Stationery, Advertising, Printing. 8. Boxes and Packing Materials, 9. Repairs, Shoeing, Veterinary and Legal. 10. Interest and Bank Charges. 11. Carriage, Cartage. 12. Postages, Trade Subscriptions, Miscellaneous. 13. Capital Expended. 14. Drawings, Personal Expenses. 15. Pulping. 16. New Implements. 17. Spraying, Payments.-1. Total. 2. Fruit Pur- Tree Grease.

Analysed Wages Book.

Labour for the week ending. .19

\begin{tabular}{|c|c|c|c|c|c|c|c|}
\hline Name. & Remarks. & $\begin{array}{l}\text { Plantn. } \\
\text { No. } 1 .\end{array}$ & $\begin{array}{l}\text { Plantn. } \\
\text { No. } 2 .\end{array}$ & $\begin{array}{l}\text { Market } \\
\text { garden. }\end{array}$ & $\begin{array}{c}\text { Glass } \\
\text { houses. }\end{array}$ & Sundries & Total. \\
\hline \multirow[t]{2}{*}{$\begin{array}{l}\text { King, J......... } \\
\text { Smith, H. ..... } \\
\text { Thompson, H... } \\
\text { Wood, T. ...... }\end{array}$} & & $\begin{array}{rrr}f & \text { s. } & \text { d. } \\
1 & 0 & 0 \\
0 & 15 & 0\end{array}$ & $\begin{array}{rrr}\text { f } & \text { s. } & \text { d. } \\
0 & 16 & 0 \\
0 & 12 & 0\end{array}$ & $\begin{array}{lll}£ & \text { s. } & \text { d. } \\
2 & 0 & 0\end{array}$ & $\begin{array}{lll}£ & \text { s. } & \text { d. } \\
2 & 10 & 0\end{array}$ & $\begin{array}{lll}2 & \text { s. } & \text { d. } \\
0 & 9 & 0\end{array}$ & $\begin{array}{rrr}\text { f } & \text { s. } & \text { d. } \\
1 & 16 & 0 \\
1 & 16 & 0 \\
2 & 0 & 0 \\
2 & 10 & 0\end{array}$ \\
\hline & & 1150 & $\begin{array}{lll}1 & 8 & 0\end{array}$ & 20 & $\begin{array}{lll}2 & 10 & 0\end{array}$ & $\begin{array}{lll}0 & 9 & 0\end{array}$ & 820 \\
\hline
\end{tabular}




\section{CHAPTER L}

\section{A HISTORICAL RECORD OF FNGLISH FRUIT GROWING.}

\section{By Cecil H. Hooper, M.R.A.C., Librarian, Agricultural College, Wye, Kent.}

Historians tell us that certainly cherries and possibly plums and apples were grown in England by the Romans, but as to whether cherry trees were imported, or whether they were grown from cherry stones is not stated. Perhaps the seeds were imported, as in later days the Spanish and English pioneers in North America frst introduced European fruits by bringing over the seeds. We learn that the Romans taught the Britons to plant the vine about A.D. 280. In the description of the garden of a manor in the eleventh century, at the time of the Domesday Book, it is said to have contained the following vegetables:-Onions, leeks, mustard, peas, and perhaps cabbage; and the following fruits:-Apples, pears, cherries, and probably damsons, plums, strawberries, peaches, quinces and mulberries, also frequently, near the manor garden, a vineyard was planted. The Domesday Book (1085) records 38 vineyards situate in the southern central counties. Needham, who wrote his "De Natura Rerum " in the twelfth century, says the vineyard was an important adjunct to the mediaeval mansion; William, of Malmesbury, says of Gloucestershire, about 1125, that the vine was either allowed to trail on the ground or else each plant was trained to a stake. A book, written in the thirteenth century to assist landowners to manage their estates, called the "Domesday of St. Paul," includes the duties of the reeve (the present day foreman or farm bailiff):- he was to rise early and have the ploughs yoked, then walk in the fields to see that all was right, and note if the men be idle, or if they knock off work before the day's task was fully done.

The monks in their day were leaders in good cultivation both of field and garden, and had orchards adjoining the monastery as at Glastonbury. The monks were good judges of land, and chose rich land with beautiful surroundings. When the fig was introduced into England is not known, but there is a fig orchard at Tarring, near Worthing, said to have been planted originally by Thomas à Beckett, say about 1170.

The severe winter of 1257 is said to have destroyed many cherry, plum and fig trees.

Edward I. (1272-1307) was a great lover of gardens; the cultivation of raspberries and currants in gardens appears to date from his time.

Edward II., when at Bockinfold, in Kent, received presents of grapes and wine, sent him from the vineyards at Rochester. In 1322 (Edward III.) two bushels of green grapes were sold for 7s. 6d. Stowe tells us that "Richard II. planted vines in great plenty, within the Upper Park of Windsor," and sold part of the produce to his people. The wine made in England was sweetened with honey, and probably flavoured and coloured with blackberries. Four or five centuries ago fine vineyards existed at Tunbridge Castle, Barming, and Hunton-atBuston, at this latter place the vines were grown on terraces on the hill side.

In the parish of Teynham, on land owned by Colonel Honeyball, is the site of the oldest known cherry orchard in Kent.

In this parish, Richard Harrys, fruiterer to King Henry VIII., obtained 105 acres of good land, divided it into 10 portions, and in 1533 bought sweet cherry and apple trees from the continent and planted the land.

This part of Kent, from Chatham to Canterbury, is still the most famous district for cherries in England; these 
orchards are on loam, over brick earth, with chalk underneath.

About 1540 good varieties of cherries were imported from Flanders and planted in Kent. It was from Holland and Flanders that our forefathers also learnt to raise better varieties of vegetables.

Flemish refugees about this time commenced the cultivation of vegetables around Sandwich, in Kent, and Norwich, in Norfolk.

In 1552 the following vegetables and fruits are mentioned as being grown:-Melons, pumpkins, cucumbers, radishes, parsnips, carrots, cabbages, turnips, salad herbs, apples, plums, pears, walnuts, filberts, apricots, almonds, peaches, figs and cornels.

Grafts of cherries were fetched from France and the Low Countries, hence the names of Bigarreau, Gean or Guienne, Gaskins or Gascoigne.

Leonard Mascall, in 1572 (Queen Elizabeth's reign), published his book on planting and grafting trees, recording the practice of France and Holland.

Lambarde, a Kentish historian, tells us that by 1586 cherry gardens and orchards had spread to some 30 neighbouring parishes between Boughton-under-Blean and Canterbury.

John Gerarde (15 $\overline{45}-1607)$ published his famous "Herbal or General History of Plants" in 1597, in which he mentions there being vineyards and hop-gardens in most places in England.

In the "Fruiterers' Secrets," published in London, in 1604, a copy of which is in the Bodleian Library, at Oxford, the following statement is made: "There are 4 sorts of cherries in England, namely, the Flemish, the English, the Gascoyne, and the Black, the fruit is protected from the birds by gun or sling, the worst enemies being jays and bullfinches, who eat stones and all. Stone fruit should be gathered in dry weather, and after the dew is off, for if gathered in wet weather it loses colour and becomes mildewed."

James I. (1603-25) had many mulberry trees planted, for silk worms, to encourage silk production, but this lacked success.

Orchards are frequently mentioned in charters and deeds granting land in the reigns of James I., and Charles I., in vari- ous parishes in Kent, where fruit is still grown.

Returning to the "Fruiterers' Secrets," published in James I. reign, we can read that " if newly gathered nettles are laid at the bottom of the basket and on the top of the fruit, they will hasten the ripening of fruit picked unripe, and make it keep its colour." (This point interested me, as I have seen my foreman place nettles in this way over plums (probably Rivers' Early Prolific) to improve the bloom and colour the fruit). Careful directions are given for gathering apples, the placing of the ladder against the trees so as not to damage the tree; the use of the gathering hook, so that branches may be brought within easy reach of the picker on his ladder; the wearing of a gathering apron, and the emptying of the fruit gently into the baskets. Green fern is said to have the same effect on pears as nettles for stone fruit; apples should be packed in wheat straw, or better still, in rye straw. For travelling long distances barrels are recommended, lined at both ends with straw, but not at the sides, to avoid heating, holes should be bored at either end to prevent heat, the fruit was to be carefully put in by hand. Pippins, John apples, Pearmains, and other "keepers," we are told, need not be turned until the week before Christmas, and again at the end of March, when they must be turned oftener, but never touch the fruit during a frost or a thaw, or in rainy weather or it will turn black."

In the "Surveyor's Dialogue," published in 1608 (in James I. reign), is this statement:- "Above all other, I think, the Kentish men be most apt and industrious in planting orchards with pippins and cherries, especially near the Thames about Faversham and Sittingbourne."

Westcote, who lived in the reign of Charles I., wrote, about 1630, "that the Devonshire men had of late much enlarged their orchards, and are very painstaking in planting and grafting all kinds of fruit." Whilst John Beale wrote, in 1656, in the time of the Commonwealth, that "Hereford is reputed the orchard of England."

Gervaise Markham, who was born in 1568 (Elizabeth's reign), and died in 1659, the last year of the Commonwealth, men- 
tions in his "Whole Art of Husbandry," published in 1635 (Charles I. reign), "that the olive was being grown in England." His advice as to an orchard was that it should be square, divided into four portions by alleys: apples of all sorts to be planted in the first portion; pears and wardens of all sorts in the second; medlars and services in the fourth. A wall, he considered the best fence; on the north wall, against which the sun reflects, you shall plant the apricot, verdochio (greengage), peach and damask plum; against the east wall the white Muskadine grape, the grafted cherries and the olive tree; and against the south side the almond and fig tree; round the outsides of the alleys plums, damsons, cherries, filberts, and nuts of all sorts, the horse cloy, and bullace (inferior wild plums). Plums were to be planted 5ft. apart, apples and other large fruit 12ft. apart. Moss must be carefully scraped off the trees with the back of an old knife, and to prevent it the trees were to be manured with swine's dung. Minute description is given as to pruning, also the washing of trees with strong brine made of water and salt, to be applied either with a garden pump placed in a tub or with squirts which have many holes (the forerunner of modern spraying).

In 1632 the first Botanical Garden in England was founded at Oxford.

Simon Hartlib, a Dutchman by birth, and friend of John Milton, in his "Legacy," published in 1651 (at the time of the Civil War), tells us "that Worcestershire and Gloucestershire have many orchards."

Hartlib recommended the growing of sainfoin and lucerne, and states that in Kent the value of land has risen from $5 \mathrm{~s}$. per acre rent to $£ 5$ by planting orchards, he adds that 30 acres of cherries near Sittingbourne sold for $£ 1000$ in one year.

Hartlib, a few years later, reckoned that there were 500 different sorts of apple in England, though, doubtless, many of these were identical, since the same apple often had two or three names in one parish.

The best apples for the table at this time were the Jennetings, Harvey apple, Golden Pippin, Summer and Winter Pear- mains, John apple, whilst for cider the Red Streak was the great favourite. A tenant in Herefordshire is said to have bought the farm he rented with the fruit crop of one year, $£ 10$ to $£ 15$ per acre having been given for cherries, and more for apples and pears. Pears then grown for dessert were the Windsor, Burgamot, Boon Christmas, and for perry, Greenfield. There were many kinds of plums, including Mistle plum, Damazene, Violet and Premorden. In 1656 Dr. John Beal wrote a book, "Herefordshire Orchards a Pattern for All England."

John Worlidge, in his "Systema Agriculturae" (1681), tells us "there were four kinds of grafting practised; in the cleft and in the bark, shoulder or whip grafting, and grafting by approach, the last named where the stock you intend to graft on and the tree from which you take your graft stand so near together that they may be joined, you take the sprig you intend to graft and pare away about three inches in length of the rind and wood near unto the same, after the same manner that they may evenly join each other, and so bind them and cover them with clay or wax."

Inoculation (i.e., budding) was also practised, "when the sap is at the fullest in the summer, the buds you intend to inoculate being not too young, but sufficiently grown." For transplanting, the middle of October is recommended, with the advice added "plant not too deep," and in clay, plant as near the surface as possible, for the roots will seek their way downward but rarely upward; in transplanting you may prune the branches as well as the roots of apples and pears, but not so with plums. The best distance apart to plant apples and pears in an orchard was considered to be from 20 to 30 feet, the further apart the more they were thought to benefit from the sun and air. For cherries and plums 15 to 20 feet apart was thought right.

Worlidge, who lived about 1640 to 1700 , also wrote on pruning, cider-making, and "A Discourse on Bees"; he advocated the culture of the vine.

The "Rural Economy of Gloucestershire," published in 1788, mentions that 
in 1707, apples sold in Liverpool at 2s. 6d. per bushel.

Daniel Defoe (author of "Robinson (rusoe"), writing in 1724 (George I. reign), states that 6,000 acres of hops had been planted around Canterbury within living memory. He writes of Maidstone as the "mother of hop grounds," and of the country round about Faversham as being famous for apples and cherries.

Richard Bradley, in 1729 (George II. reign), records that ground never esteemed worth a shilling an acre had been rendered worth $£ 40, £ 50$, and sometimes more pounds a year by planting hops judi. ciously, and that $£ 30$, and even $£ 50$ clear profit per acre had been made from hops. Bradley, in 1726, gives a long list of pears, all with French names, hardly any of which are now known in England.

Mr. Chevallier, of Aspall Hall, Suffolk, sold cider in 1742 at 10d. a gallon; in 1745 at 1s. per gallon; whereas in 1746 apples sold at 4d. per bushel, and cider only fetched $6 d$. per gallon.

In the "Compleat Cyderman," written in 1754 (George II.), appears the statement referring to apple orchards in Devon, Cornwall, and Hereford, that under tillage apple trees grow as fast again as under grass, and that in Kent crops of corn were grown between the trees; it adds, that orchards should be sheltered from east wind, which brings swarms of imperceptible eggs and insects in the air. Perry pear trees are mentioned as making a good screen. In the hard frosts of 1709 , 1716 , and 1740 , it records that great numbers of fruit and other trees were destroyed by frost.

In Devonshire, top dressing over the roots of old apple trees with soil from roads and ditches was practised, chalk and lime were also used. Care was taken of the heads of the trees to prevent the branches interfering with one another, and the heads were made to spread as much as possible; at this date the apple, orchards in Devon excelled.

In Herefordshire, we are told, the roots of the apple trees were laid bare and exposed for 12 days of the Christmas holldays that the wind might loosen them, the roots were afterwards covered with a compost of dung, mould and a little lime.
The method of planting apple trees recommended was to take off the turf, lay it back by itself, then the next earth, called virgin mould, to be laid also by itself, next, put horse litter over the bottom of the hole with some of the virgin mould over the 'roots, then spread old horse dung over this and upon that the turf leaving it in a basin shape. The ground in a young orchard in Devon was first planted with cabbage, next with potatoes, next with beans, and so on, until the heads of the trees became large enough, when the land was allowed to return to pasture.

In 1763 the rent of good land in Devon was about $£ 1$ per acre, that of good orchard land $£ 2$.

The following is an estimate of the cost per acre of making a cider orchard in Devonshire in 1763:-

132 apple trees, at $2 /-(18 \mathrm{ft}$. apart) $£$ s. d. £ s. d.

(The custom had been to plant 160 trees to the acre, but this distance (16 $\frac{1}{2} \mathrm{ft}$. apart) was considered too close.)

Carriage per tree at $2 \mathrm{~d}$., manure per tree at $3 \mathrm{~d}$., planting per tree at $3 \mathrm{~d}$.

$\begin{array}{lll}13 & 4 & 0\end{array}$

Interest on $£ 17$ 12s. for 15 years before the orchard became profitable, at 5 per cent.

Loss of half the rent of the land for the same period at $10 /$ - per acre ...

Building cellarage for product per acre

$£ 43 \quad 4 \quad 6$

Whilst the following is given as the yearly expense :-

Rent of one acre of cider orchard ...... £2 00

Tithe on 10 hogsheads, at $6 \mathrm{~d}$.

Gathering, making and carriage to and

from the pound, at $3 / 6$ a hogshead...

Racking twice, at $6 \mathrm{~d}$.

1150

Casks and cooperage

$£ 413 \quad U$

The following was the estimated yearly receipt :-

10 hogsheads of cider, diminished by

racking and waste to 8 , selling at $12 / 6$

per hogshead ......................... £5

leaving $7 \mathrm{~s}$. for risk of spoiling. 
The above was used as an argument against a proposed increase in excise of $4 \mathrm{~s}$. a hogshead, which was opposed, and taken ofit.

Notes on the history of English fruit growing would be incomplete without the mention of Thomas Andrew Knight (17581838), who lived at Downton, in Herefordshire, he was probably the best practical gardener of his day. After graduating at Oxford he made research into various points of vegetable and animal physiology; in 1785 he read before the Royal Society a paper upon the inheritance of disease among fruit trees. Noticing that excellent old varieties of fruit deteriorated and became more subject to clisease, he raised new varieties by taking pollen from the blossoms of celebrated apples and placing it on the blossoms of hardy apples and crabs; this system he carried out on cherries, pears, plums, nectaries, strawberries and potatoes. Yellow Ingestrie is one of the apples he raised; Monarch, a pear; but perhaps he was really most successful with cherries, of which Waterloo, Elton Heart, Knight's Early Black and Black Eagle are some of the best known. In 1797 he published a treatise on the culture of apple and pear, and on the manufacture of cider and perry. He was president of the Royal Horticultural Society, and during his time many European varieties of fruit were sent to the United States of America to be tricd there.

In Worcestershire, from about 1845, fruit planting seems to have increased quickly in the Evesham valley; here, beside a soil eminently suited to market gardening and plum growing (especially the native Pershore Yellow Egg plum), tenants and landlords have learnt mutual confidence as to fruit planting, which proves an advantage and security.

Since the development of the railway system the acreage of fruit has steadily increased. The first Kentish railway, "The South Eastern," was completed about 1846; the Chatham and Dover railway was built some years later to take people and produce even more rapidly to and from the Continent; there has been the temptation to favour foreign produce as to rates and quick delivery. It is to be hoped that both British and foreign produce will be treated fairly in the future.

William Topley, in his "Geology of the Weald" (1875), writes: "The most fertile district of the Hythe beds is that near Maidstone. Enormous quantities of hops are grown here, also filberts and fruit."

The abolition of the duty upon sugar in 1874 gave a great impetus to jammaking, and consequently to fruit production.

About 1880 Lord Sudeley erected the first preserving factory on a fruit farm on his large fruit estate at Toddington, in Gloucestershire. Here fruit was boiled into pulp in steam heated pans, then placed in barrels, to be reboiled with sugar for jam when the fruit season was over. About 1880, as apple drying in America was making great strides, and an evaporating factory at St. Catherines, Ontario, Canada, was drying 150 bushels of apples a day at a temperature of 160 to 170 deg. F., evaporation of apples and plums, also crystalizing fruits, was tried successfully in England.

In about 1880 fruit-farmers began to plant apple, pear and Morello cherries as "bush trees" on dwarfing stock, the trees commencing to branch at one or two feet from the ground, as these trees come into bearing earlier than standard and halfstandard trees.

In 1884 the Extra-Ordinary Tithe Act was passed, whereby no further tithe rent charge could be levied on newly planted fruit or hops.

Since 1880, Agricultural Holdings Acts and a Market Gardeners' Compensation Act have been passed, these have helped farmers, but not fruit growers, as solicitors always find a way of avoiding it in the case of fruit planting; and a tenant proposing to plant fruit needs to search for firstly, suitable land, and secondly, the goodwill of a landlord.

Between the years 1876 and 1885 the "Herefordshire Pomona" was published by the Woolhope Naturalists' Field Club, edited by Robert Hogg and Dr. Henry Graves Bull; this work, in two volumes, illustrating apples and pears grown at that date, is, we believe, the best illus- 
trated work on apples and pears in the world.

Among the introductions of the last thirty-five years are steam and other mechanical transport of fruit on road; spraying machinery suitably designed for orchards and fruit plantations; co-operative auction markets; fruit canning factories; improved and lighter cultivating implements to save hand labour; box and barrel packing of apples, and smaller packages for soft fruits; investigations as to insect and fungus pests of fruit; the study of pollination and insect visitors of fruit blossoms to thereby increase production; motor cultivating and spraying implement's for fruit plantations to save horse labour; observations and experiments in fruit growing problems, sprays, manuring, pruning, \&c., by the late Mr. Spencer Pickering at Woburn, by the
Royal Horticultural Society at Wisley, the John Innes Horticultural Society at Merton, Dr. Dyer and Mr. Shrivell at Hadlow, near Tonbridge; the classification and trial of different stocks used for apple, plum, \&c., at the Malling and Bristol fruit experiment stations; the use of pigs to cultivate and manure fruit plantations; the use of the tramway on the fruit farm; preparation of woodland previous to planting by blowing up the tree stumps by high explosive as by the Brothers Fourdrinier at Pershore; and powder spraying as practised by Mr. Paget Norbury at Malvern.

As to the sources of some of the above information I am chiefly indebted to W. H. R. Curtler's "A Short History of English Agriculture"; Donald McDonald's "Agricultural Writers, 1200 to 1800 "; and the various essays on "Fruit Farming" by the late Sir Charles Whitehead. 


\section{APPENDIX.}

\section{Varieties of Fruit Now Grown for Profit in North-West Kent.}

Kindly supplied by SIDNEx LeE, of Crockenhill, Kent.

Strawberrims.-Paxton (if it will grow), Laxton (liable to mildew), Laxtonian (not very robust), Sovereign (getting weaker).

RusPbeRRIES.-Hornet, Superlative, Devon. GooseberRY.-Lancashire Lad.

Red Curirant.-Fay's Prolific (early but susceptible to frost), Raby Castle, Wilson's Long Bunch (late).

Black Currant.-Baldwin, Seabrook's, Edina. Plums.-Victoria, Czar, Pershore Yellow Egg.

Prars.-Conference, Marillat, Louise Bon, Jules Guyot (on quince), Fertility, Hessle con pear' stock).

Apples.-Bramley, Newton Wonder, Albert, Grenadier, either Early Victoria or Rivers' Early, Worcester, Allington and King Pippin.

Apples and Pears for Cordons.-Messrs. W. Seabrook and Sons, of Chelmsford, who have great experience with cordon trees, have given me their opinion as to the best varieties for commercial purposes. Generally speaking, Stirling Castle, Lord Derby, Lane's Prince Albert, James Grieve, Allington Pippin and Cox's Orange Pippin are the best six apples; and Conference, Dr. Jules Guyot and Marguerite Narillat the best three pears for cordons.

Cherries (recommended by Mr. Fred Smith for Kent).-Early Rivers, Waterloo, Kentish Bigarreau, Napoleon and Kentish Preserving.

ApRICOT TREES are trained on the walls of nearly every house in Aynhoe, in Northamptonshire; it is therefore called "the Apricot Village," the variety chiefly grown being "Moorpark." In many cases the produce of the trees pays the rent of the cottage.

Distances recommended for Planting Frult Trees in Kent on good fruit land; on poor land the distances may be reduced.

Cherries (spreading), 35 to 40 feet apart, 35 to 27 per acre:

Cherries (smaller growing), 25 to 35 feet apart, 70 to 35 per acre.

Apples, standard (strong growers), 30 feet apart, 48 per acre.

Apples, standard (smaller growers), also halfstandard (strong growers), 20 to 25 feet apart, 109 to 70 per acre.

Pear and Plum standards (Bush and Black Diamond plums), 20 feet apart, 94 per acre.
Apples, bush (strong growers), and Plum, halfstandard (spreading, as Rivers'), 15 feet apart, 194 per acre.

Apples, bush on Paradise, and Plums (upright growers), 12 feet apart, 302 per acre.

Pears on quince, 10 feet apart, 435 per acre.

Gooseberries and Currants, 5 to 6 feet apart, 1,742 to 1,210 per acre.

Habit of Growth of Fruit Trees in Kent.

Apples of strong growth : Bramley, Newton, Annie Elizabeth, Beauty of Bath. Apples of intermediate growth: James Grieve, Rival, Allington, Worcester, Lord Derby, Cox's Orange. Apples of weak growth : Lane's, Grenadier, Early Viotoria, Stirling Castle, Gladstone.

Pudms of strong growth: Czar, Belle de Louvain, Bush, Pond's Seedling. Monarch. Plums of weak growth : Victoria, Rivers' Early Prolific, Pershore Egg, Pershore Purple, Damson.

Pears (for bush at 12 feet apart) : Conference, Dr. Jules Guyot, Fertility, Durondeau, Clapp's Favourite, Hessle. (W.M.)

Number of Varieties of Apple on a Farm.

For 50 acres of apple plantation ten varieties of culinary and six varieties of dessert apples will afford an ample range of variety. Under present market conditions it is advisable to confine one's selection to varieties that can be sent to market straight off the trees, the returns of which can be snugly harvested in the grower's bank by the first week in October. (W. G. Lobjoit.)

\section{Best Varieties for Regrafting.}

Apples.-Bramley, Newton, Derby, Victoria and Early Rivers (if plenty of space); Grenadier and Prince Albert (if space limited). (S. L.)

Pears.-(1) Conference, (2) Hampton's Bergamot. The variety for regrafting pears must be a strong grower and healthy, and will vary with the district. (S. L.) Windsor is recommended for regrafting old pear trees by $\mathrm{Mr}$. Cuthbert Smith.

Plums.-Regrafting not usually satisfactory ; neither are they often headed back, as damsons used to be, for fear of "silver leaf."

Cherries. - Napoleon has been successfully used for regrafting cherry trees in order to improve the varieties, but regrafting cherries is not always successful, as they are apt to gum.

\section{Length of Life of Fruit Trees.}

That apple trees will live to 200 years or longer is shown by a tree at Horton, in Buckingham. 
shire, where a tree exists-or till recently existed-which is said to have been a large tree in the time of Milton (1608 to 1674), who, in his younger days, used to sit under its shade. I have seen a Nonpareil apple tree of great size at Cornwallis Rectory, Nova Scotia, Canada, said to have been planted by the French previous to their expatriation in 1755.

old pear trees, healthy and still bearing, can be seen at Detroit, Michigan, U.S.A., planted there by French missionaries more than 250 years ago. Some of the giant pear trees of Herefordshire, Worcestershire and Gloucestershire must be nearly or quite as old.

The Economic Duration of Fruit was put by one of the largest East Kent growers as 14 or 15 years for Raspberries, 20 to 25 years for Plums, 60 to 70 for Cherries and up to 100 years for Apples.

\section{Labour Required for Fruit Growing and Marker Gardening.}

On a fell sheep farm on the Cheviots one man is required to about 1,000 acres; on a fruit farm $£ 6$ to $£ 8$ is spent on hand-labour per acre in cultivation, exclusive of picking expense. In Australia one man can work 10 acres of fruit land, with the help of one man for three months; two men can work 18 acres. The trees are 20 feet apart on the square, with nothing between, the whole being cultivated by horse. Mr. Hugh Mumford, of Pershore, told me that, on his fruit and vegetable farm of 40 acres, he employed about 16 persons in winter (ten men and six wornen), and in summer 40 to 50 persons, of whom 25 were engaged in picking fruit; in 1920, he spent $£ 1,465$ in wages (including bonuses to men, women and pupils). Nearly all fruit farms grow vegetables or flowers between the fruit or as rotation; these chiefly include runner beans, broad beans, peas, cauliflowers, spring broccoli, sprouting broccoli, spring cabbage, onions, spring onions, potatoes and wallffowers. For information on regetable growing for market I know of no better book than "The Profitable Culture of Vegetables for Market Gardeners, Smallholders and Others," by Thomas Smith. (Longmans.)

\section{Number of Pickers Required for a Certain Acreage.}

For strawberries, five or six pickers per acre; for raspberries for jam, four persons per acre; for plums, about the same number; damsons are picked after the plums.

\section{Tractor Cultivation of Fruit Plantations.}

Perhaps the best at present in use is the Cletrac caterpillar tractor, which will hoe 6 to 10 acres of apple plantation a day. I was told that a 25-horse-power Cletrac costs about $£ 375$. I saw two at work on a farm near Maidstone, where, in addition to the driver's standard wage, he was paid an acreage bonus of $6 \mathrm{~d}$. per acre for ploughing and $3 d$. per acre for harrowing.
These tractors also haul the fruit to the road to the road-tractor lorries. At Brenchley a caterpillar tractor is used to draw a hop sprayer (seven acres a day being possible), which was also used to spray tall apple and cherry trees.

\section{Quantity of Spray used per Acre.}

'Tu spray an acre of five to seven-year-old trees took 240 gallons; to spray large, old plum trees, 6CO gallons per acre, on Mr. E. P. Whiteley's farm at Pershore. Washing with caustic alkali, copper sulphate or lime occupies considerable labour in late winter. Winter washing takes more liquid than summer spraying. To spray with limewash large, old apple trees and tall cherries took 900 gallons per acre.

\section{Approximate Cost of Different Spraying Washes per 100 gallons. \\ (Materials bought at wholesale prices, May, 1921.)}

Winter Cueansing Washes.-Caustic soda, 20lbs. per 100 galls. of water, 18s. Lime spray, 1cwt. quicklime per 100 galls., 20s.

Insecticides.-Arsenate of lead, 6lbs. per 100 galls., 8s. Nicotine, 6ozs. per 100 galls, 9s. 6d. Combined arsenate of lead and nicotine, per 100 galls., 17s. Nicotine 6ozs, soft soap 5lbs. per 100 galls., 12s. Quassia 10lbs., soft soap $10 \mathrm{lbs}$. per 100 galls., 10s. Paraffin 2 galls., soft soap $3 \frac{1}{3}$ lbs. per 100 galls., $6 \mathrm{~s}$.

Fungicides (Winter Washes). - Copper sulphate, 4lbs. per 100 galls., 6s. Caustic soda $10 \mathrm{lbs}$, soft soap 10lbs. per 100 galls., 12s. Limesulphur, $6 \frac{1}{2}$ galls. per 100 galls., 20s.

Fungicides (Summer Washes).-Bordeaux mixiture, 8lbs. copper sulphate, 8lbs. quicklime per 100 galls., 13s. Lime-sulphur, $12 / 3$ galls. per 100 galls., 5s.

Combined Fungicide and Insecticide (Summer Washes).--Lime-sulphur $12 / 3$ galls., nicotine 6ozs, per 100 galls, 14s. Lime-sulphur $12 / 3$ galls., arsenate of lead 6lbs. per 100 galls., 12s. 6d.

Powder for Gooseberry Sawfly CaterprLtar.-Hellebore, $4 \mathrm{~s}$. per $\mathrm{lb}$.

For details as to mixing and making the above sprays, see Food Production Leaflet No. 39.

\section{Dry Spraying.}

In England for this work "Belumnite" is employed for aphides, etc. In America the dust is composed of 10 to 15 per cent. arsenate of lead powder and 85 to 90 per cent. hydrated (slaked) lime or gypsum. If for fungous diseases, as well as for caterpillar, sulphur is used in place of the lime or gypsum.

\section{Spraying Maxims.}

E. G. Lodeman, late Instructor in Horticulture at Cornell University, in "The Spraying of Plants," says :- "Be prompt, thorough and persistent. Ínowledge and good judgment are more necessary to success than definite rules." 


\section{Grease Banding.}

In Kent, for banding fair-sized apple trees, the cost is estimated at about $£ 1$ per acre. In Worcestershire, where the trees are chiefly plums, rather closely planted, my brother told me locally-made grease cost him £60 for 30 acres.

Ringing Fruit Trees to bring them into Bearing.

Near Malvern, Mr. F. Paget Norbury showed me espalier apple trees which had not been bearing. On the trunks of some of these, at about 6 inches from the ground, he had cut out a ring of bark $\frac{1}{4}$ inch wide, leaving $\frac{1}{2}$ to $\frac{3}{4}$ inch uncut. The trees thus treated had far more blossom this spring than the trees not so treated.

Blowing Up Tree Stumps with High Explosive.

Mr. N. D. Fourdrinier, of Pershore, from his experience in blowing up forest trees, considered three men could get out stumps of fruit trees, 18 feet apart, at the rate of an acre co day.

Old Hose Pipe makes excellent collars for tying fruit trees to stakes to protect the trees from the cutting of cord or wire.

Apple Jelly Recipe of the Horticultural College, Swanley, Kent.

Apples too small for market are quite good for making into apple jelly. They should be mature; hard, sharp apples are best, such as Bismarck and Keswick. The apples are wiped, cut up. with peel and core, placed in stone jars, just covered with cold water, and baked for 12 hours. If placed in copper or pans they should only just simmer for the same length of time.

The apple pulp is then strained through a jelly bag of tammy (or through soup cloth tied over a chair), either of which has been previously wrung out in boiling water. The straining continues for 24 hours.

The pulp should not be pressed or squeezed, or the juice will be cloudy.

Good cane preserving sugar is used, 1lb. to every pint of juice; the sugar should be slightly baked in a cool oven for 15 minutes to warm the sugar, but not sufficiently to colour it, before adding to the juice.

Cloves and lemon are added at the rate of two cloves and the rind of half a lemon to each pint of juice. The cloves and lemons are tied up in a muslin bag.

The juice is boiled for 30 minutes before adding the sugar, and after the sugar is added it is boiled very quickly and skimmed well for 10 or 15 minutes, or till the jelly thickens, when a little is put in a saucer to cool.

Strain again through a muslin (previously wrung out in hot water) into a hot jug, with a good pouring spout, and pour from this into hot glass jars, very clean. The colour of the jelly depends a good deal on the apples used.

Large Yields of Fruit.

Plum.-112 Pershore Egg plum trees on 0.65 of an acre (two roods 24 perches), in 1920, yielded
258 pots of fruit of $721 \mathrm{bs}$., equal to nearly 400 pots per acre-i.e., over $12 \frac{1}{2}$ tons to the acre; beside this, about 10 pots were lost owing to their dropping through being over-ripe, so the yield is rather underrated, on farm of G. F. Hooper, Pershore, Worcestershire. In the same year Mr. Harold Martin gathered 10 pots of fruit from four Monarch plum trees (equal to 180Ibs. per tree); and for the fruit from a quarter-acre allotment at Broughton, chiefly planted with Purple Pershore plum, he received $\$ 90$ gross. Mr. Fred Smith; of Loddington, near Maidstone, once had 20 bushels of plums from a Black Diamond tree, which variety is an irregular cropper and does not usually crop heavily.

Mr. Thomas Francis Rivers, of Sawbridgeworth, Herts., said in 1875, at the Surveyors' Institution, that two acres of Early Prolific plums, planted as pyramids 6 to 12 feet apart, had produced 800 bushels of fruit (10 tons per acre). Rivers' Early Prolific crops well in grass orchards, as among cherries.

Apple.-In 1919, 80 acres of apple and plum plantation, when 17 years old, trees 15ft. apart, yielded 200 tons of apples and 100 tons of plums, on farm of H. S. Bickham, Hilltop, Leabury, Herefordshire.

In 1919, 200 trees of Bramley's Seedling, when 15 years old, yielded 2,500 bushels of apples on Colonel Clive Murdoch's farm, Westerhill, Linton, near Maidstone.

In 1919, an orchard of Blenheim Orange, planted by Mr. F. Paget Norbury, near Malvern, when 21 years old, yielded an average of six pots per tree, but it was only their second year of cropping.

In 1919, a four-acre grass orchard of Blenheim Orange and Newton Wonder, trees $30 \mathrm{ft}$. apart, yielded an average of $12 \mathrm{cwts}$. per tree, on farm of George Jones, Pinvin, Worcestershire.

Bramley's Seedling apple trees, when 15 years planted, produced $3 \frac{1}{2}$ bushels each on an average, and at 40 years old for three years in succession yielded an average of 15 bushels per tree. At this age the trees had a circumference of $100 \mathrm{ft}$. and trunks 18ins. in diameter. Plantation of Messrs. Merriweather (the introduicers of this apple) at Southwell, Nottingham.

Perhaps the record yield was 900 bushels per acre of Bramleys, which was reached on $\mathrm{Mr}$. Wimshurst's farm at Wadhurst, Kent.

Pear.-In 1920, six old pear trees yielded fruit to the value of $£ 45$, there being an exceptional crop selling at an exceptional price, on Mr. Shackle's farm, Comberton, Worcestershire.

Some old Perry pear trees in the West of England sometimes yield a ton of fruit yearly. which, containing $4 \frac{1}{2}$ lbs. potash, withdraws from the soil $1 \mathrm{cwt}$. of potash in 30 years. (Clement Cadle.)

Cherry.-In 1919, a Cluster cherry tree produced 90 half-bushels (28lbs.) of fruit, or $22 \frac{1}{2}$ 
cwts. ; and an acre of cherries yielded $2 \frac{1}{3}$ tons of cherries, on Mr. W. J. Jennings' farm, Kennington Hall, near Wye, Kent.

In 1917, Sir Walter Berry, of Gushmere Court, Selling, Kent, found his largest cherry trees bore $12 \mathrm{cwts}$. of fruit, the smaller trees (Early Rivers, Black Circassian and Governor Wood) 4 to 5 cwts. each; he finds Napoleon and Kentish Bigarreau flourish better on arable land than most varieties of cherry do.

Taking an average of 10 years' recent sales by auction of some 179 acres of orchard fruit, chiefly cherries, in seven parishes around and including Sittingboume, in Kent, the average price per acre was $£ 24$; in 1921 the highest sold at $£ 50$ per acre for the fruit. It is considered that a really good, well-established cherry orchard should yield, on an average, a return of $£ 30$ per acre. Between Canterbury and Chatham good cherry orchards let at $£ 8$ to $£ 10$ per acre and sell at $£ 200$ per acre, and even as much as $£ 300$ per acre for the best in full bearing.

AVERAGE FrUTt Yield OF ENGLAND PER Acre.-Under a Census of Production Act made in 1908 the following were the estimated yields per acre :-Apple, 26 owts.; pears, 19 cwts.; cherries, 15 cwts.; plums, 46 cwts.; strawberries, 29 cwts.; raspberries, 22 cwts.; black currants, $9 \mathrm{cwts}$; red and white currants, $18 \mathrm{cwts}$. ; gooseberries, 21 cwts.

Sir Charles Whitehead estimated the average apple crop of Great Britain to be 130 bushels per acre (say 48 cwts.), but that up to 500 bushels рег acre had been obtained (say 9 tons $8 \mathrm{cwts}$.).

Mr. Cuthbert Smith, a very experienced and practical Kentish grower, estimated the yield of a well-cultivated standard apple orchard to be 280 bushels, the trees being on free stock, planted $40 \mathrm{ft}$. apart with one in the middle, 56 trees per acre, averaging 5 bushels per tree; and for bush apples on Paradise, well done, 335 bushels per acre, the trees 18ft. apart, 134 trees per acre, at $2 \frac{1}{2}$ bushels per tree.

RETURN EXPECTED,- It is stated that an ordinary well-managed farm should realise 15 to 20 per cent. per annum on the capital invested.
Price of Land and Orchards.-Much good land suitable for fruit is sold at $£ 30$ to $£ 50$ per acre; but in fruit-growing districts $£ 100$ is often required. At Wisbech, Cambridgeshire, for excellent land the lowest price is said to be $£ 80$, ranging up to $£ 150$ and even $£ 200$ per acre; whilst for good orchards $£ 350$ per acre has been paid. In the well-known cherry district of Sittingbourne, in Kent, $£ 200$ for orchards is a common price; and at Pershore, for plum orchards, £200 or more. Tenant right for fruit trees in the Evesham Valley amounts to from $£ 60$ to $£ 120$ per acre.

Cost of benng PUPIL on a Weld-Managed and Successful Fruit Farm.-For pupilage only, $£ 50$ to $£ 80$ per year; if with board and lodging, $£ 200$ per annum for one year or better for two years. For this payment the fruitgrower should give time to teach his pupil, including manual dexterity, management of labour, buying and selling, also showing him his accounts and results.

Necessaries for a Frutt Farmer.-Capital, energy and diligence.

The Advantages of Co-operative Marketing of Fruit are: (1) Reduction of the cost of marketing; (2) improvement in the distribution of the produce; (3) increased demand for the produce; (4) standardisation; and (5) protection of the individual grower.

\section{Local and Central Fruit Growers' Associations, Demonstrations, Fruit Experiment Stations and Colleges.}

Fruit growers should support and work with the local fruit growers' associations and, if funds allow, subscribe to the Central Federation, also to the local Bee-keepers' Association, to encourage the little helpmate of the fruit grower. They should also take interest in any Fruit Experiment Station or College dealing with fruit growing in their district and visit and associate with other fruit growers in their neighbourhood, as it is-

"By mutual confidence and mutual aid, Great deeds are done and great discoveries made." 


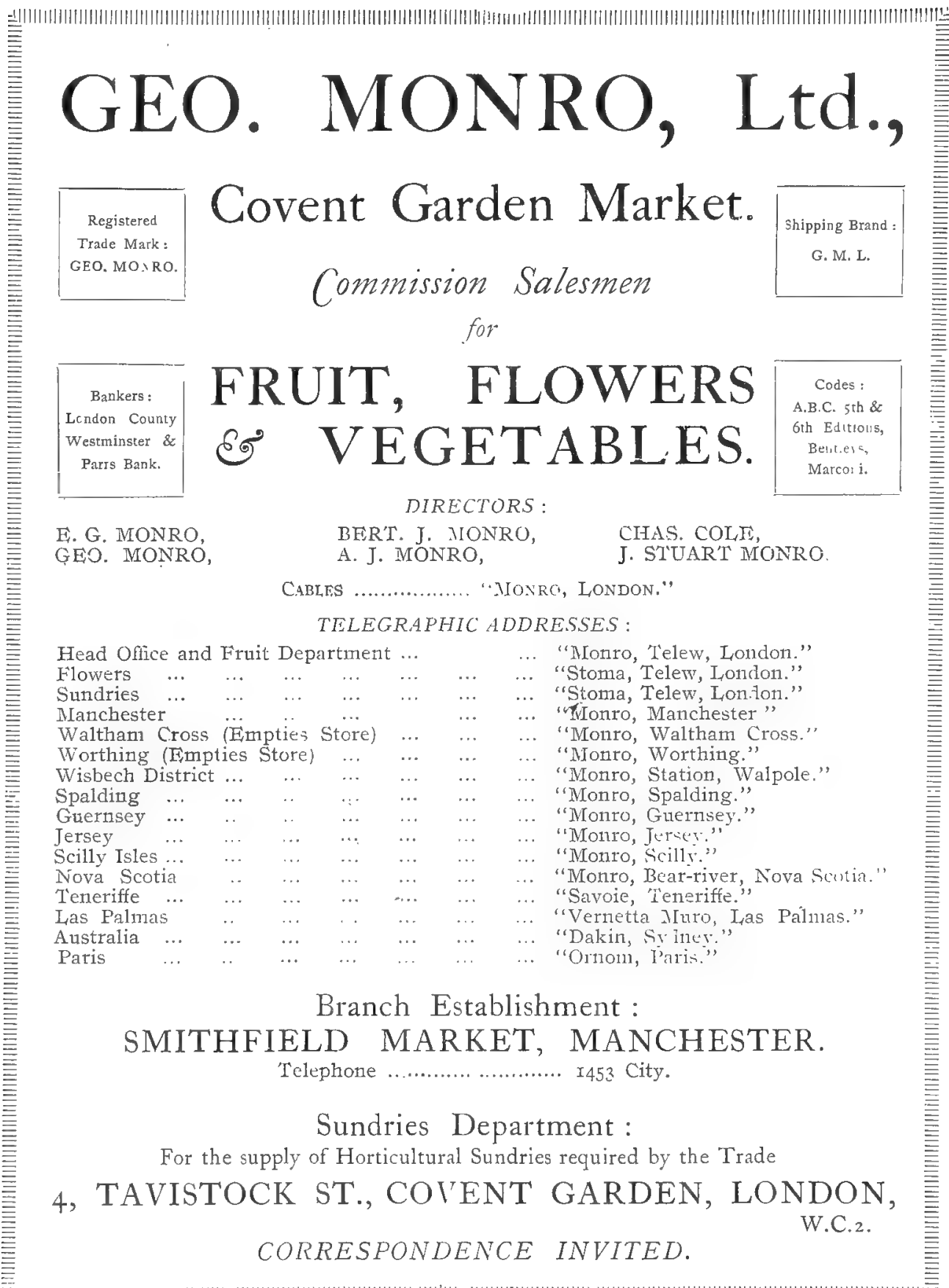




\section{INDEX.}

Acts of Parliament Bearing on Fruit PAGE Farming :-

Agricultural Holdings Acts of 1883, 1895, $1900,1906,1908,1914$ and $1920 . .3,8,15,17$

Agricultural Rates Act of 1896 .............. 17

Destructive Insects and Pests Act, 1907... 191

Extraordinary Tithe Redemption Act, 1896

Ground Game Act, 1880.

191

Gun Licence Act, 1870

18

Market Gardeners' Compensation Act, 1895

Public Health Act, 1875

Agreement, Difficulty " that the Holding should be Let or Treated as a Market Garden "

8,16

American Gooseberry Mildew .................. 122

Analysis Cash Book of Receipts and Payments on a Farm $182-5$

Animals in Grass Orchards .................... 61 Aphides (See Insect Pests) ... 42, 50, 58, 63, 75,

Apple 132,125 $46-50,61$

Double Grafting .............................. 154-5

Manuring .................................. 94

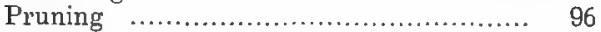

Apple, Gathering ...................48, 51, 52, 69 Apple, History of Well-known Varieties...135-138 Apple, Insects Injurious to (See Insect Pests), Insect Visitors to Blossoms ...... 159

Apple Jelly Recipe ............................ 195

Apple, Order of Blossoming ............... 156-160

Apple, Packing in Baskets and Boxes 52, 167-172

Apples, Self-fruitful or Self-sterile 135-138, 148-9

Cross Pollination Experiments .............. 150-1

Apple, Tree Canker (See Fungoid Diseases).

Apple, Raising New Varieties of ...........155-157

Apple, Storage ................................ 52-3

Apple Trees, Length of Life .................. 52

Apple, Varieties of ........................ 46-47

Apricot Village, Aynhoe, Northamptonshire 192

Arrangements between Land]ord and Tenant

10 to 13

Arsenate of Lead ................................. 50-58

Aspect ........................................... 20

Australian Fruit Growing .................. 110-112

Basis for Fruit Planting Compensation ..... 14

Bees 158,159
Birds in Relation to Fruit and Injurious Insects ..................................... 103-9

Big Bud Mite (Phytoptus ribis) .............. 39

Black Currant ............................. 39-41, 59

Reversion ...................................... 41-161

Packing ....................................... 69

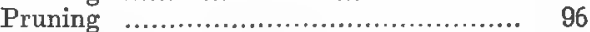

Black Currant Cuttings ...................... 161-162

Blowing up Tree Stumps ....................... 194

Book-keeping on a Fruit Farm or Market Garden ................................... 182-5

Bordeaux Mixture ..................... 50-51, 117

Box Packing of Apples and Pears ......... 167-172

Buildings-Compensation for ............... 17

Buildings for a Small Fruit Farm.............. 4

Canada, a History of Fruit Growing in ...... 114

Capital Required for Fruit Farming .........4, 5, 6

Care of Spraying Machinery, Tools, Implements, Baskets ..................... 83, 84, 87

Caustic Soda Wash .............................. 50

Cherry ..............................................61 to 63

Packing $\quad \ldots \ldots \ldots \ldots \ldots \ldots \ldots \ldots \ldots \ldots \ldots . \ldots . \ldots . \ldots, 166$

Pruning ..................................... 96

Cherry, Cost of Planting Standard Trees ... 61

Cherry, Diseases of ............................ 62

Cherry, Insects Injurious to ................... 63

Cherry, Morello ................................ 61-63

Cherry Orchards, Price and Rent ........... 62

Cherry, History of Varieties, Description, Order of Flowering, Self-fertile, Selfsterile ...................................... 145-7

Cherries, Yield of ................. 49, 62, 194, 195

Chestnut, Eating or Spanish .................... 67

Chestnut Fencing ............................... 67

Clean Land Before Planting, Importance of 48

Cob and Filbert Nuts ......................... 64-65

Cob Nuts, Cost of Planting and Cultivation and Yield ................................ 64-65

Compensation for Fruit Planting-Strawberries, Raspberries, Currants, Apple, Plum, Pear and Nut Trees, Manures, $\& \mathrm{c}$.

Cordons, Apples and Pears as ...... 152, 153, 192

Cost of Cultivation Operations on Fruit, Market Garden, and Farm Crops ... 6, 32, 34, 35,37 to $41,62,175-6$

Cost of Fruit Picking ......................... 70 Cost of Planting Fruit, \&c. ... 5, 6, 11, 48, 50, $61,62,173-5$ 


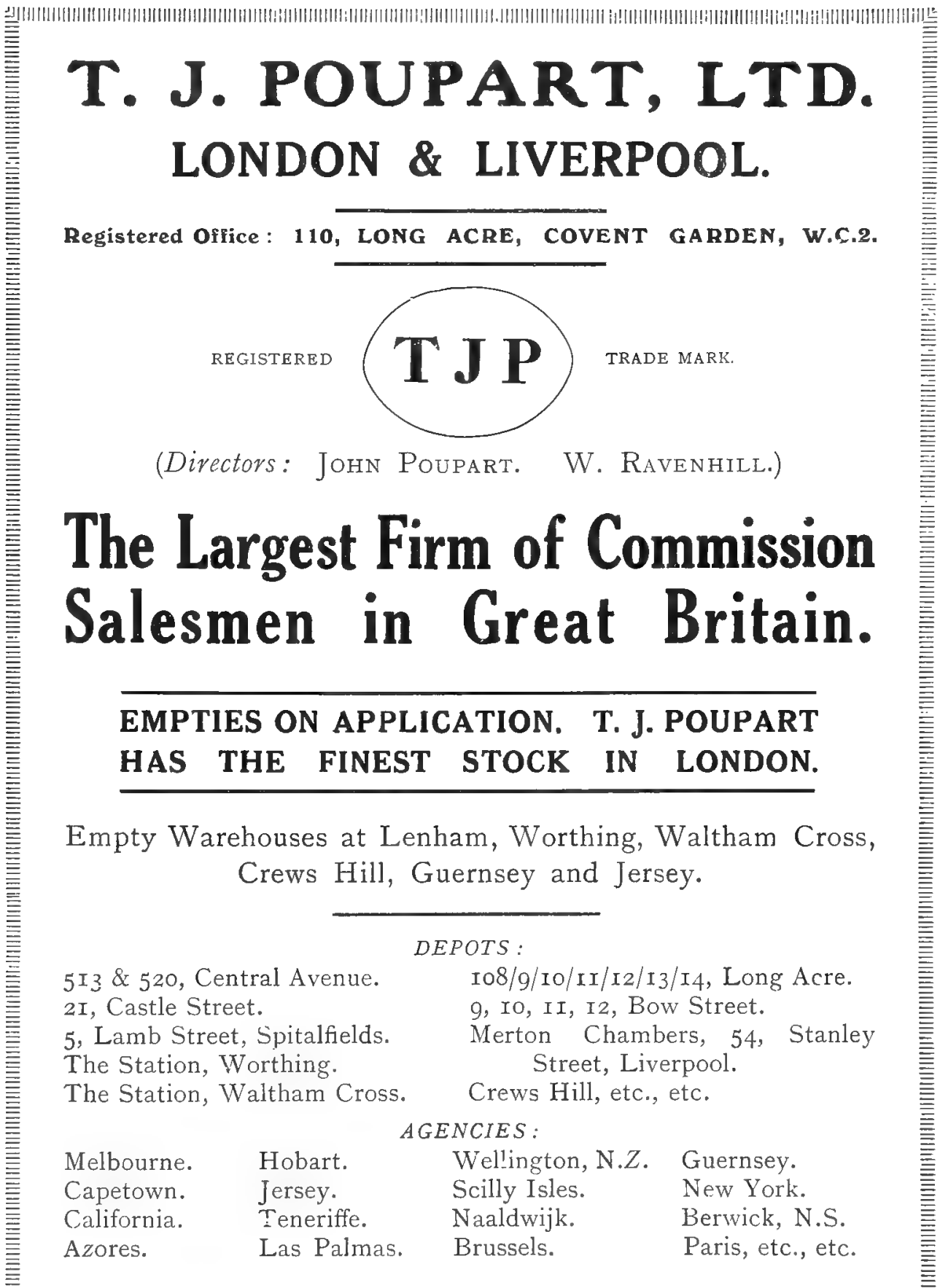

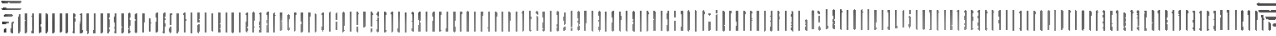


Cost of Maintaining a Plantation ... 4, 11, 35, 37 $41,50,62,64$

Cust of Spraying with Lime and Sulphur,

Lead Arsenate, Nicotine ................ 82-86

Counties, Conditions as to Fruit in different $10-14$

Cover Crops for Orchards ........ 24, 36, 114, 115

Cross-pollination, Advantages of ... 30, 54, 57, 58

Cultivation Book for Fruit Crops .............. 182-5

Cultivation of the Soil ............. 22, 23, 24, 110

Cuttings of Gooseberries and Currants ... 40, 161-2

Currant, Picking ................................ 69 Manuring (.................................. 94

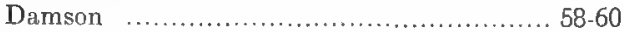

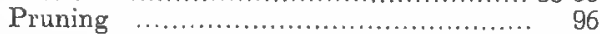

Demonstration Orchards for Spraying, Pruning, \&e. ............................... 115

Diary of : Fruit Farmer ..................... $72-75$

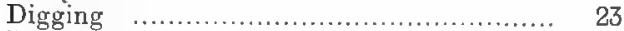

Diseases of Fruit Crops (See Fungous Diseases).

Double-grafting ........................... 154-155

Drainage of Land for Fruit ................... 173

Dry Spraying ................................ 193

Education of a Fruit Farmer ................ 1, 2

Enfranchisement of Copyhold .............. 3

"Evesham Custom" ........................ 9, 12

Extension Rods for Spraying .................. 79

Farm Operations, Cost of ................ 175-6

Farm, Choice of .......................... 7

Federation of British Grower's Standard Bushel Box .............................. 169

Fencing

Fish Salt for Raspberries, Assists Moisture of Soil

Fruit Experiment Station, Cost paid by Government in Australia and Canada 113. 115

Fruit Plantation Marker (made by Messrs. Gibson, of Eynsford, Kent)

Fungicides ......................... 81-82, 117

Fungoid Diseases of Fruits, The Most Common ................................. 116 to 124

American Gooseberry Mildew (Sphaerotheca Mors-uvae ....................... 38, 122

Apple Mildew (Podosphaera leucotricha) 118

Apple Scab or Black Spot (Fusicladium dendriticum) …............51, 81, 82, 117

A pple Tree Canker (Nectria ditissima) 112, 119

Brown Rot of Plums, Cherry, Apple (Sclerotinia or Monilia fructigena) ... 51, 82,

Dia-back of Gooseberry Bushes (Sclero-

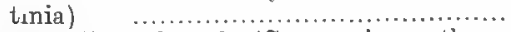

Cherry Leaf Scorch (Gnomonia erythrostoma)

Crown-gall of Apple and other fruits (Bacterium tumefaciens) .........................

Gooseberry Mildew (European) (Microsphaera grossulariæ) .......................

Loganberry Stem Blotch (Hendersonia rubi)
Nummified Plums (Sclerotinia fructigena)

PAGE

Peach Leaf Curl (Exoascus deformans) ... 124

Peir Scab (Fusicladium pirinum) ...... 54, 117

Raspberry Stem Fungus (Coniothyrium Fuckelii ....................................

Shot-hole Fungus (Cercospora circum-

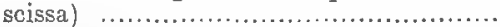

Silver Leaf in Plum and Apple (Stereum

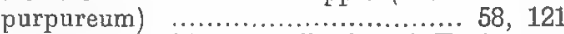

Strawberry Mildew on Leaf and Fruit (Sphaerotheca fragariæ)

Game Laws.

Gathering Baskets Lined with Sacking to prevent Bruising

General District Rates

18

Glasshouse Rating ......................... 18

Gooseberry .............................. 37, 38

Manuring .................................. 93, 94

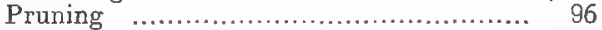

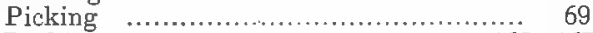

Packing $\quad$............................... 165, 167

Gooseberry, Diseases of ..... 38, 82, 96, 122, 123

Gooseberry, Insects Injurious to the ........ 132

Grading of Fruit ............ 68, 69, 70, 165-172

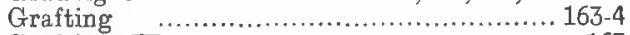

Grafting Wax ............................. 163

Grass Orchards, Cost of Planting with Fruit 25

Grass under Fruit Trees .............. 25-26, 60-61

Grease Banding Tree Trunks.......... 53, 58, 194

Gumming of Stone Fruit Trees ................ 62

Habit of Growth of Fruit Trees ..............

192

Hares and Rabbits harm Fruit Trees, Protection against, Shooting and Snaring of ....................................... 18, 61

Headlands .................................... 173

Hellebore for Gooseberry Sawfly Larva ..... 132

Hive-bee, Its Great Value as a Pollenizer 158-159

Implements $22-26$

Insecticides 125,133

Insect Pests of Fruit, The More Common 125-128 Aphides ........................ 42, 58, 63, 125 Apple Aphides (Aphis mali, \&c.) ........ 50 Apple Blossom Weevil (Anthonomus pomorum) ..........................111, 126, 128 Apple Sanfly (Hoplocampa Tenthredo testudinea) (........................... 51, 127 Apple Sucker (Psylla mali) .............50, 125, 129 Black Currant Big Bud or Gall Mite (Eriophyes ribis) ....................128, 132

Capsid Bugs on Apple, \&c.

Cherry Black Aphis (Miyzus cerasi) ......
Clearwing Moth (Sesia tipuliformis), Larvæ in Stems of Currants ............ Codling Moth (Carpocapsa pomonella)

Damson-Hop Aphis (Phorodon humuli) 132

Elephant Bug on Strawberries ............... 42 
Telephone Nos.: 3083 GERRARD.

676 ,
Telegrams : "BOTANIZING, RAND, LONDON."

Codes: A.B.C., 4 th \& 5 th Editions \& Modera Economy

\section{RID:}
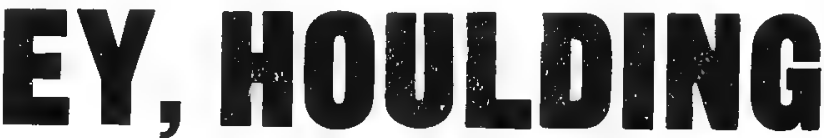

\& COMPANY

*

We handle all kinds of English Orchard Produce, and have exceptional facilities for handling bulk quantities.

Best market prices always obtained for well graded and carefully packed fruit.

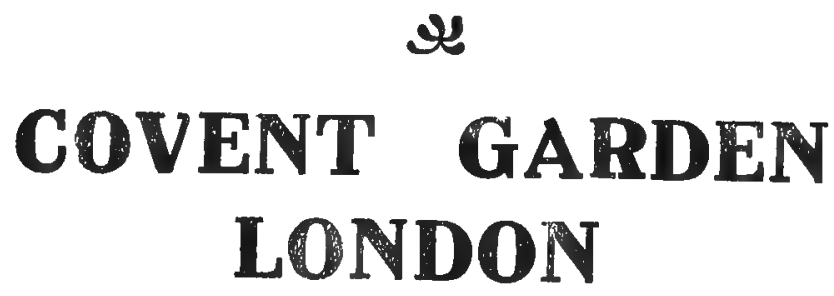


Gooseberry and Currant Sawfly (Nematus ribesii) ............................. 128

Green Fly, See Aphides ..... 42, 58, 63,

Lackey Moth (Clissiocampa neustria) ...

Leaf-curling Plum Aphis (Aphis pruni)

Magpie Moth (Abraxas grossulariata), Caterpillars on Gooseberry and Red

Currant $\quad$.......................... 128, 132

March Moth (Anisopteryx aescularia) ... 50

Mealy Plum Aphis (Hyalopterus pruni) 132

Mottled Umber Moth (Hybernia defoliaria)

Pear Leaf Blister Mite (Phytoptus (Erio-

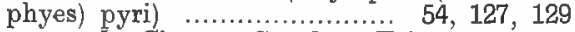

Pear and Cherry Sawfly (Eriocampa umacina)

Pear Midge (Diplosis pyrivora) 54, 127, 129

Plum Aphis (Aphis pruni) ................ 132

Raspberry Beetle (Byturus tomentosus) $36,45,132$

Red-legged Weevil (Oriorpynchus tenebricosus) (.................................. 127

Rosy Apple Aphis (Aphis sorbi) ........... 125

Scale on. Apple, Gooseberry, Currant 125-128

Slug-worm of Pear and Cherry (Eriocampa limacina)

Strawberry Chafer Beetle (Cetonia aurata) Grubs .................................. 32

Weevils (Curculio) ..................... 126, 127

Winter Moth (Cheimatobia brumata) ... 50

Woolly Aphis (Schizoneura Ianigera) 126, 130 $125,130,131$

Insect Visitors to the Different Fruits ... 158, 159

Insurance of Fruit Pickers and other Workpeople against Accidents, Importance

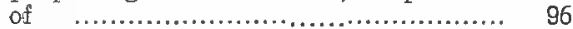

Interplanting, Permanent and Temporary

Trees

Invoice Book

Knapsack Pumps $78,87,80,88$

Labour Book $182-5$

Labour, Obtaining of ..................... 7 Quantity Required for Fruit Growing ... 193

Ladders for Fruit Picking .................. 68

Land, Preparation of .......................... 4

Landlord's Side in Fruit Planting ...... 10, 38

Law in Relation to Fruit Growers and

Market Gardeners ...................... 13-18

Laying out of Land for Fruit Planting ... 27-29

Lease for Fruit Growing ............... 3, 8, 16

Length of Life of Fruit Trees ........ 52, 192-3

Legal Expenses of Preparing a Lease ..... 176

Legal Position of Tenant who Plants Still Uncertain .............................. 3, 12

Lime Wash, Largely Used in Worcestershire 57,58
Lime, Sulphur, Salt Wash for Pear Leaf

Blister Mite ............................. 127

Jime-Sulphur Wash ... 50, 51, 81, 82, 117, 123

Lime-Sulphur Steam Boiled Superior to Self-Boiled

Loganberry $43-45$

Lucerne in Orchards 26

Map of Planting ............................. 30

Manuring of Various Fruits ........ 4, 31, 34, 37, $48,49,89,93,95,173-4$

Marker for Fruit Planting .................... 24

Market Experience Valuable ................. 1

Market Gardeners' Compensation Act, 189513

Marking Board ............................. 28, 29

Martin's Seedling or Pershore Purple Plum (Preface)

Measureland of Land ................... 177, 181

Mulching Newly-Planted Trees, and those with much Fruit

Nicotine Wash

Orchard Houses ................................ 153

Order Book .................................. 182, 185

Order of Flowering of Different Varieties of Apples

Pears

139-141

Plums

$142-144$

Order of Ripening of Fruits .............. 56, 63

Owls and Hawks, the Fruit Growers' Friends

Packing and Grading for Markel-Sorting Table

Packing Demonstrations at Fruit Shows and Elsewhere .............................

Packing of Strawberries .......................

Raspberries

Cherries

Apples

Pears

Plums

70

33

36

52

55

68

Paraffin Jelly ................................. 125

Pear $54-56,70$

Packing $\quad$....................................... 167

Pear, Diseases of. See Fungoid Diseases 54, 117

Pear, Histories of Some Well-Known

Varieties ..................... 139, 140, 141

Pear, Insects Injurious to. See Insect Pests 54 127,129

Pear; Length of Life .......................... 54

Pear, Order of Flowering ................... 56

Self-Fruitful and Self-Sterile Varieties 139-141

Pear Trees Lining Fruit Plantation Roadways

54,55

Pear, Varieties Recommended for Market and Season ......................... 55, 56

Picking and Packing of Fruit "68, 165-172, 193

Picking, Cost of ........................ 70, 193 


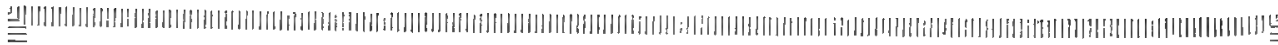

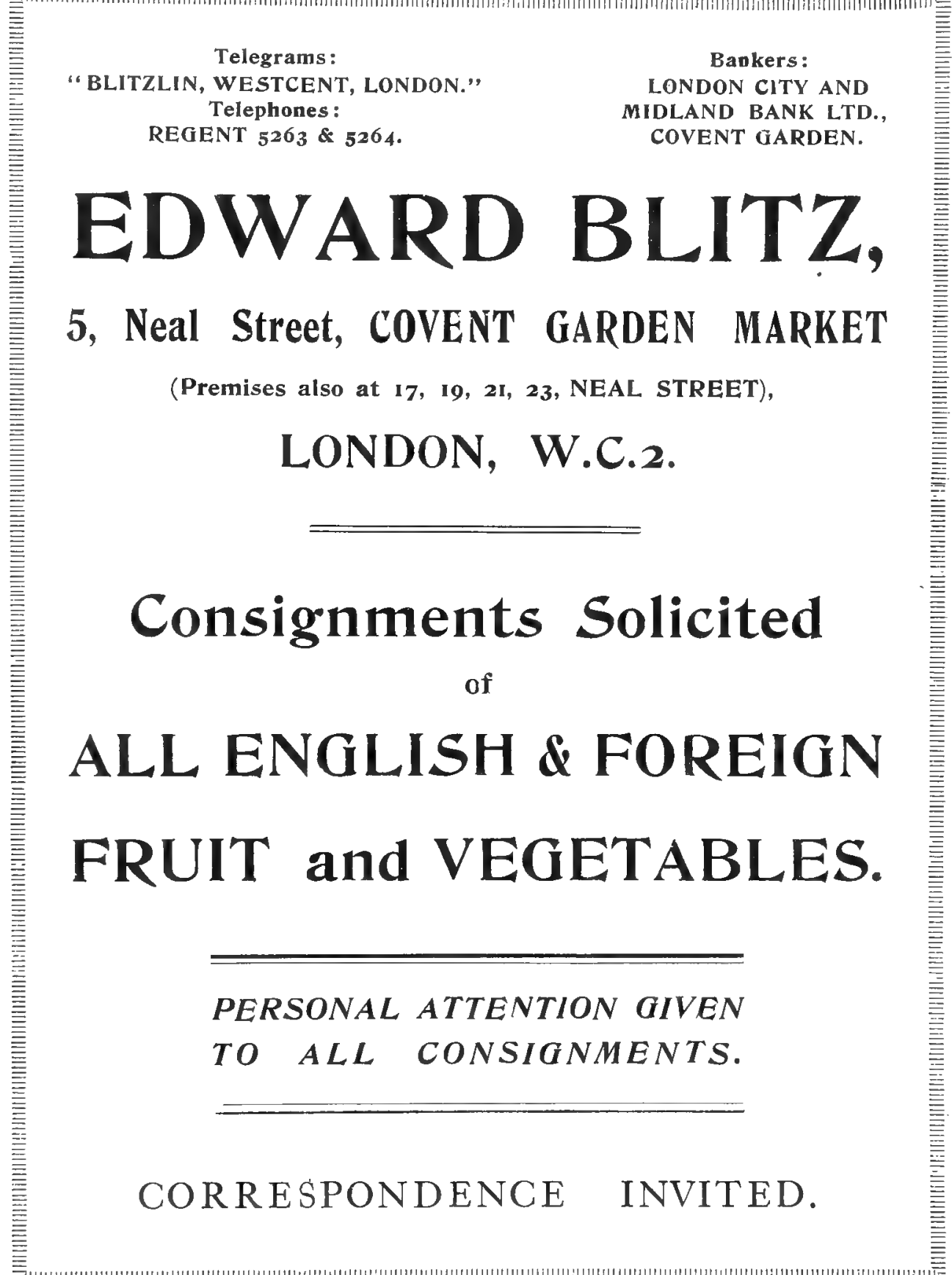

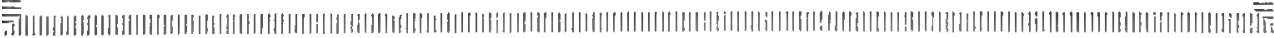


PACE

Picking Sack-"Glewston Fruit Farm" ,.. 69

Piecework-Prices on Fruit Farms ........... 176

Pigs in Orchards sometimes Beneficial ..... 162

Plan of Planting .............................. 30

Planting Board ....................... 28, 29, 97

Planting Fruit Trees ......... 4, 10, 12, 27, 29, 98

Planting on Square, Triangle or Quincunx 29

Ploughing and Plough for Fruit Plantations

Plum ................................. $57-60$

Thinning $\quad \ldots \ldots \ldots \ldots \ldots \ldots \ldots \ldots \ldots \ldots \ldots \ldots, 71$

Packing .............................. 69, 166, 167

Plum, History of Some of the Best Known Sorts 142,144

Plum, Cost of Planting ....................... 59

Plums, Insects and Diseases of ... 42, $50,51,58$ $63,82,119,120,121,125,126,130,132$

Plum, Life of ................................ 59

Plum, Manures for ............................ 94

Plums, Specially Suitable for Canning ..... 59

Plum Varieties .................................. 57 Order of Flowering .......................... 58 Whether Self-Fertile or Self-Sterile 142, 144

Pneumatic Sprayers .......................... $76-80$

Potash (Caustic) for Cleaning Bark ........ 133

Pollination and Fertilisation of the Various Fruit Blossoms ...............57, 58, 156, 166

Power-spraying Machinery .................. 77

Preparation of Land for Fruit Planting ...... 4

Price of Gooseberry and Currant Bushes 42

Price of Fruit ............................... 33, 41

Price of Land for Fruit Farming ........... 195

Protection of Useful Birds, Lessening of

Destructive Birds ...................... 103-9

Pruning Implements .................... 96, 97, 98

Pruning of $\nabla$ arious Fruits .................. 96

Pruning, Principles to be Remembered in 96, 111

Psylla or Apple Sucker .............50, 125, 127

Public Eealth Act, 1875, in relation to Rating of Fruit Land .................. 18

Pumps for Spraying ........................... 85-88

Pupil, Cost of being a Pupil on a Good Fruit Farm

Quassia and Soft Soap

Quit Rent

Raspberry, Field Cultivation of..... 34-36, 42, 69 , $94,95,96,166,167$

Raspberry Beetle (Byturus tomentosus) on Loganberry

Ra Loganberry ................................. 45

Rating of Fruit and Market Garden Land... 17

Rating of Glasshouses under Public Health Act and under Agricultural Rates Act

Record or Map of Planting

Red Currant ...................... 38, 39, 42, 69

Red Oil, the great Australian Insecticide...

Red Spider on Apple, Plum and Gooseberry Leaves

Reversion in Black Currants

161
Regrafting, Unsuccessful Varieties and Old

PAGE

Trees ............................... 163-4, 192

Ringing Fruit Trees to bring them into Bearing

Sawfly, Larvæ on Gooseberry Foliage... $128-132$ Sawfly Maggot in Apples ................ 51, 127

Sciences Bearing on Fruit Growing ......... 2

Selection of a Farm for Fruit Growing ... 7-9, 20

Self-boiled Lime and Sulphur ............... 82

Self-fertile and Self-sterile Fruits 57, 58, 156, 157

Self-moving Motor Spraying Apparatus 76, 80

Setting Out Land for Planting ............. 27-30

Sheep, the Best Graziers for Grass Orchards 61

Shelter ….......................... 7, 20, 21

Shooting Licence, Rights ....................... 18

Silver Leaf in Plums and Apples (Stereum purpureum) ..........................49, 121

Situation of Fruit Farm ..................... 7, 20

Smaller Packages ........................... 69

Soft Soap and Quassia ....................... 50

Sod and Mulch System ....................... 26

Soil Cultivation ................................. 23

Soil Fumigation with Disulphide of Canbon

Soil, Site and Shelter for Fruit Planta-

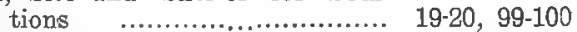

Spraying by Pipes Laid Under or on Ground ....................... 49, 77, 85, 86

Spraying Calendar ...................... 50, 133, 134

Spraying Machinery and Appliances 76-80, 112

Spraying Machinery, Care of ................ 77

Spraying Maxims ............................ 193

spraying, Quantity of Spray Used per

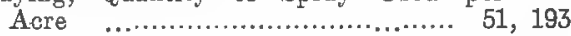

Cost of Spray ............................ 193

Standard Sizes of Apples for Packing 167-172

Storage of Fruit ............................. 52

Strawberry, Field Cultivation of ......... $31-33$ $42,69,93,96$

Packing .................................. 165-6

Strawberry Beetles (chafer grubs) .......... 32

Strawberry Mildew .......................... 32

Strawberries after Woodland ................. 31

Sulphur for Strawberry Leaf Mildew ...... 32

Summer Washes for Insects and Fungi ... 133

Syringes for Spraying Bushes and Trees ... 76

Tenants' Fixtures ............................. 17

Thinning Apples and Plums ................... 71

Tilth, Importance of, in resisting Drought... 51

Tithes Act of 1836 ............................ 190

Tobacco Leaves for Aphides and Apple Sucker ............................50,58, 63

Tools Required for Adjusting Spraying Apparatus ....................................

Training of the Fruit Farmer .................

Trespass and Damage to Crops and Trees ...

80

1

18

132 Uncertainty of Legal Position of Tenant who Plants 


\section{BARNETT}

Barnett Emanuel.

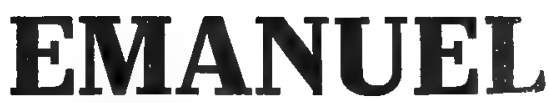

Simeon Emanuel, O.B.E.

Central Avenue,

\section{COVENT GARDEN MARKET,}

And BRanches.

- Agencies all over the World.

The Largest Commission Salesmen in

Great Britain of

South Hants STRAWBERRIES

Worcestershire ASPARAGUS.

\section{CORRESPONDENCE INVITED.}

Telegraphic Address:

"BARneyman, RAnd, London."

Telephone Nos.:

GERRARD 6246-6247.
Codes:

A.B.C. 5TH Ėdition. VTestern U'nion. 
Varieties Recommended $34,40,42,46,47,56$, 57,192

Wallflowers, sow in April .................... 73

Planted out in September .................. 74

Walnuts for Roadside Planting, Cultivation, and Yield

Walnut, Pollination ............................. 66

Winter Washes to Destroy Lichen, Fungous

Spores, Insects, \&c. .................... 50, 133

Winter Fungicide Wash for Fruit Trees ... 193

Wire Netting Trees and Fencing Round

Fruit Plantations, Cost of ............... 173-4

Woolly Aphis on Apple Tree Bark ... 112, 125,

Fields of Small Fruits and Varied Prices ... 33 , $36,38,41,43,44,48,49,52,59,194-6$

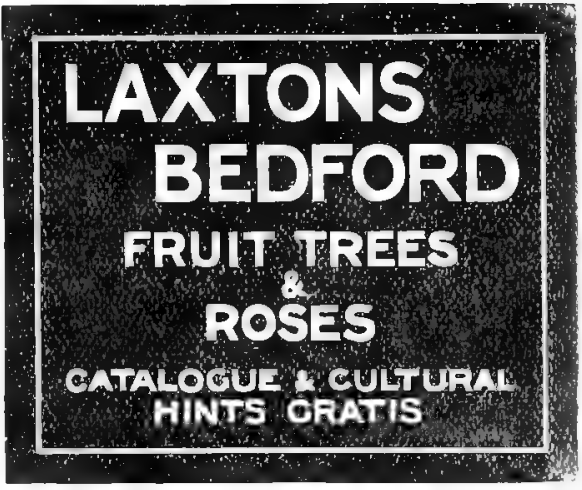

\section{To Buy or Sell a Fruit Farm, Nursery, Market Garden or Small Holding Messrs. AUBREY \& CO., 6, GOLDSMITH STREET, CHEAPSIDE, LONDON, E.C.2} are Specialists in the Sale of the above class of Properties, and Vendors or Purchasers would do well to communicate with them.

\section{Telephone: CENTRAL 859.}

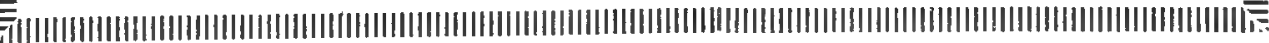




\title{
Edward Holbrook,
}

\author{
$\substack{\text { RECISTRERD } \\ \text { TRADE }}$ Fruit. Flower, and \\ MARK. \\ Potato Salesman,
}

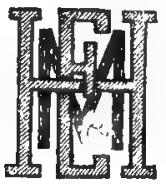

WHOLESALE SQUARE,

SMITHFIELD MARKET,

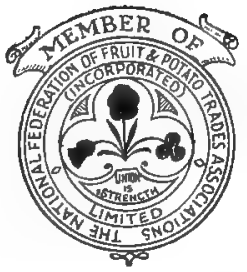

\section{MA NCHESTER.}

LONG EXPERIENCE

Old Established CONNECTION COMMANDING POSITION FACILITIES FOR HANDLING A N D

Separate departments for each kind of produce, under expert management, and personal supervision, ensuring quick disposal to best advantage.

Telegrams : "Filbert, Manchester."

Telephone: 740 City.

Bankers: Williams Deacons Bank, Limited, Manchester. 


\section{ESTABLISHED I860.}

Telegrams:-BILBERRIES, BLACKBURN. HARTLEY, ASSEMBLY, LIVERPOOL.
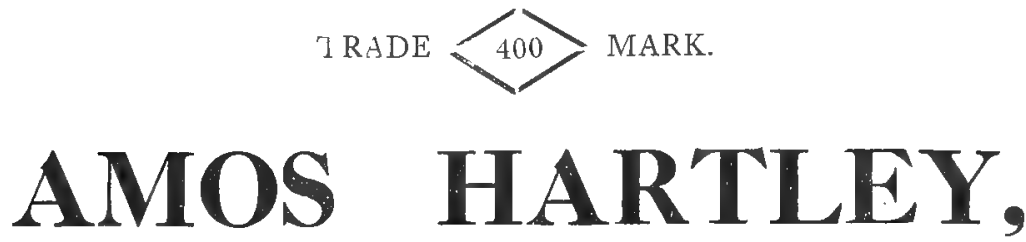

ENGLISH \& CONTINENTAL

FRUIT \& FLOWER SALESMAN

AND COMMISSION AGENT,

\section{8, VICTORIA STREET, BLACKBURN.}

Consignments of choice FRUIT and FLOWERS solicited and handled to the best advantage by experienced Salesmen. ENQUIRIES AND CORRESPONDENCE INVITED.

EMPTIES

ON
APPLICATION.

A c SALES AND

CHEQUES AS DESIRED.

ALL GREEN FRUIT SALES ATTENDED.

BUYERS requiring good representative at principal Auction Sales should communicate with me.

BANKERS: L NCASHIRE AND YORKSHIRE BANK, LTD. 


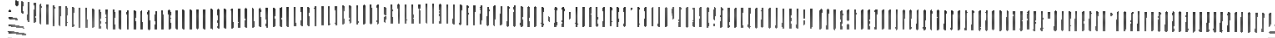

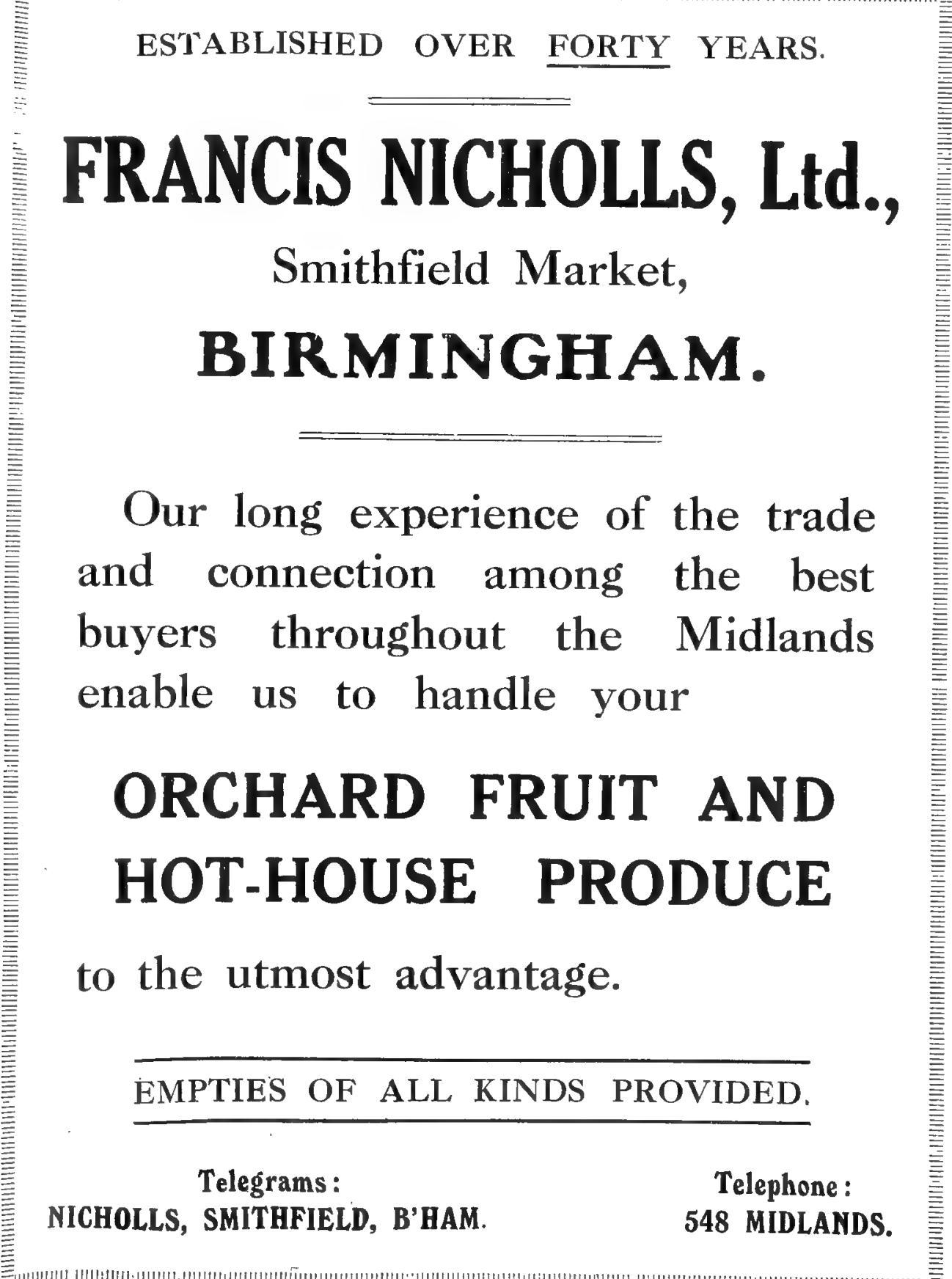

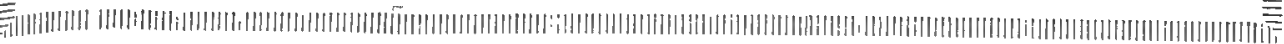


Telephone: Midland 879.

Telegrams : Fruit, B'ham.
Bankers : London City \& Midland.

Established 1875.
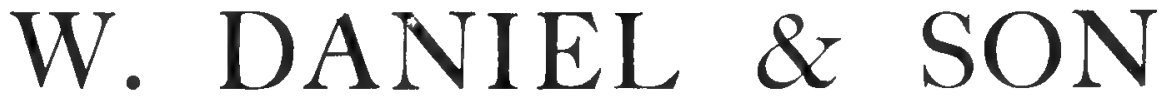
Smithfield Market

\section{BIRMINGHAM}

SPECIAL DEPARTMENTS "for TOMATOES, CUCUMBERS, GRAPES.

FLOWERS AND ALL HOT-HOUSE PRODUCE.

POTATOES AND VEGETABLES OF ALL KINDS.

ENGLISH FRUITS AND FOREIGN FRUITS OF ALL KINDS.

EMPTIES SUPPLIED.

\section{CECIL H. HOOPER, F.S.I.}

Land Agent, Surveyor and Agricultural Valuer,

BRIDGE STREET, WYE, KENT.

Specialist in Fruit Farming and Market Garden Valuations;

Measurement and Plans of Fruit Plantations.

ADVISER IN FRUIT GROWING TO THE COUNTRY GENTLEMEN'S ASSOCIATION.

For the Sale and Letting of Farms in conjunction with Messrs. R. J. GEERING, F.A.I., and F. H. COLYER, F.A.I. Auctioneers and Estate Agents,

BANK CHAMBERS, ASHFORD, KENT, and 2. KING STREET, ST. JAMES'S, LONDON, S.W.1. 


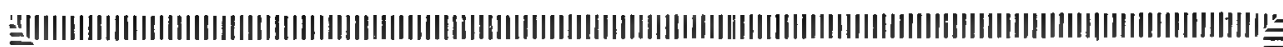

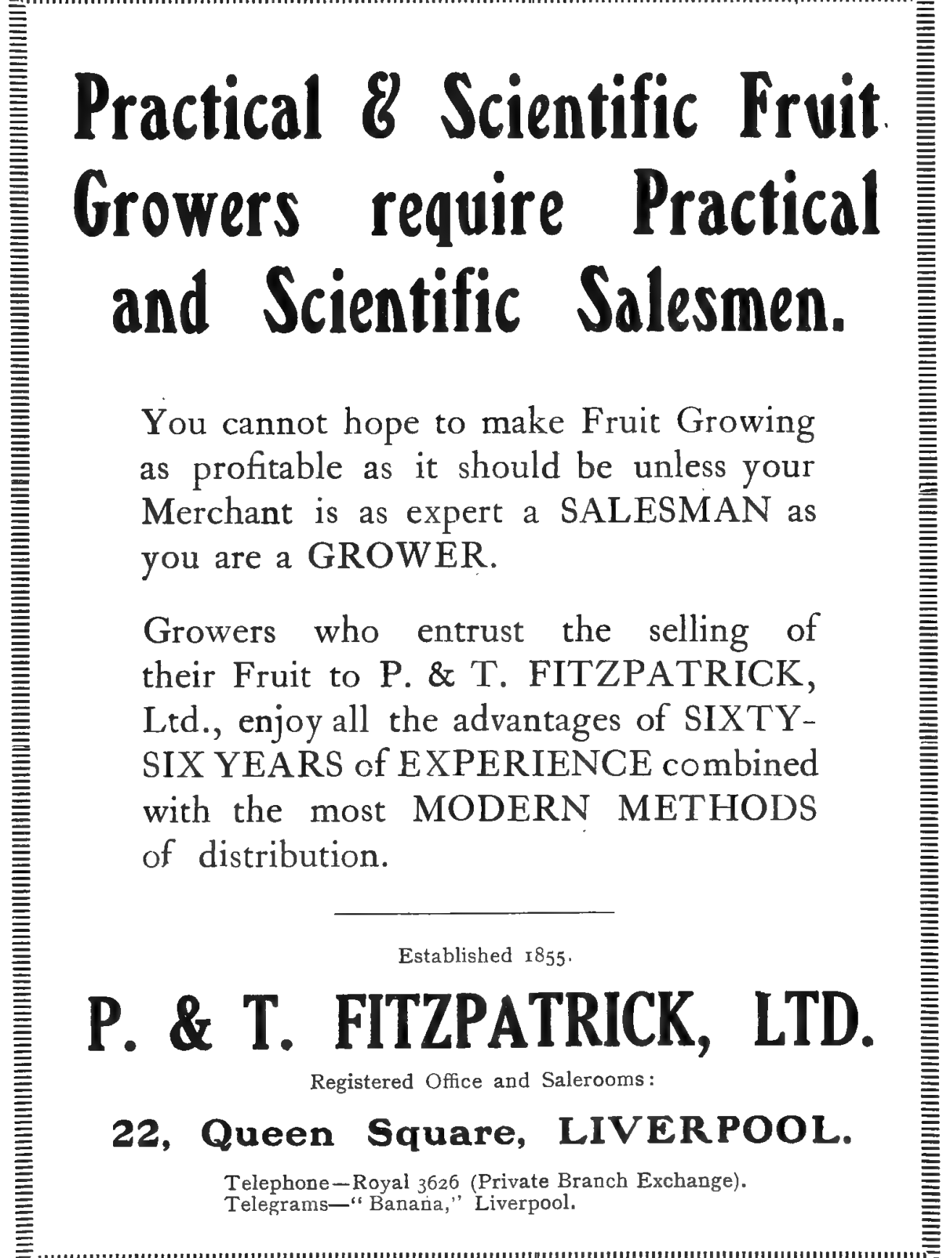

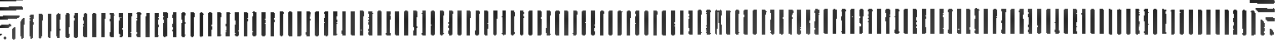




\section{Books for Fruit Growers \& Others}

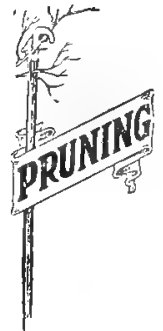

ILLUSTRATED.

Ds

A Compendium of Outdoor Work

sis

Written by a Practical Fruit Grower for Fruit Growers, with Special Supplement for Small Holders.
"PRUNING."

Price 1/- net. Post Free 1/2.

Showing in practical manner the surest and safest method of pruning all varieties of outdoor trees.

"THE SCIENCE \& PRACTICE OF MANURING."

(REVISED AND ENLARGED EDITION.) By W. DYKE.
Price 2/ net.
Post Free $\mathbf{2} / \mathbf{2}$

In 13 Chapters:- Origin and History of Manures. Plants and their Food. Influence of Manures on Crops. Soils and their Influence on Manuring. Soil Fertility Partial Sterilisation. Facts to Guide Cultivators. General Manures. Concentrated Fertilisers (continued). Fertilisers for Vegetables. Fertilisers for Fruit. Fertilisers for Flowers. Points to Remember when Manuring.

"HINTS \& WRINKLES ON TOMATO
CUITURE FOR MARKET."
By "OBSERVER" (J. Stoddart).
Post Free 1/2.
"If "Get.
"If vain our toil,
We ought to blame the culture,
Not the soil."-Pope.

"CUCUMBER CULTURE"

A Complete Treatise for Commercial Purposes. By W. DYKE, F.R.H.S.

In II Chapters. Bound in Cloth. Price 1// net. Post Free 1/2. 


\section{DO YOU SEND TO GLASGOW?} If not-Why not?

Muirhead \& Maxwell I

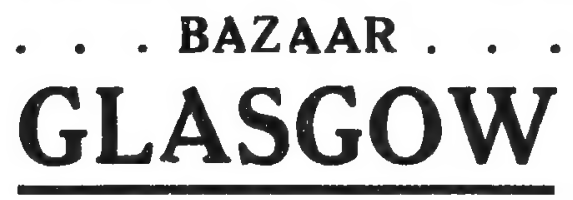

Our Prices for APPLES during the past season BEAT ALL RECORDS

We can HANDLE QUANTITY We can HANDLE QUALITY We can find you EMPTIES We can give you SATISFACTION

sp

Choice APPLES, PEARS, PLUMS A S P ECIALIT Y

WE INVITE CORRESPONDENCE. WITH B E S T G R O W E R S

Sale Accounts Daily

Cheques Weekly $\$$

Try GLASGOW this Season 


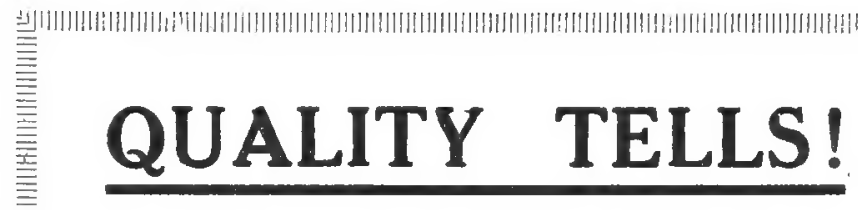

This is as true in Journalism as in any other sphere.

\title{
The Fruit, Flower and Vegetable Trades' Journal.
}

3d. Weekly of all Neresagents. Twelve Months' Subscription (52 issues), 15s.; Foreign, 21s. post free.

\author{
Popularly known as

\section{"THE FRUIT TRADES' JOURNAL,"} \\ this is the Journal of Quality for al' engaged in the Indus- \\ try, whether as Growers, Market Salesmen, or Retailers.

\section{THE JOURNAL} \\ is recognised as the leading Organ of the Industry, with \\ the widest and most influential circulation, supplying a \\ reliable service of news, Market Prices, and Sound Cul- \\ tural Information.
}

Send for Specimen Copy (post free) to

\section{THE FRUIT TRADES' JOURNAL, 1, Mitre Court,} Fleet Street, London, E.C.4. 


\title{
WEEKS'
}

Royal First Prize

\section{SPRAYING MACHINERY.} Awarded Eighteen Highest Prizes since 1909 including

The Only R.A.S.E. Award this Century.

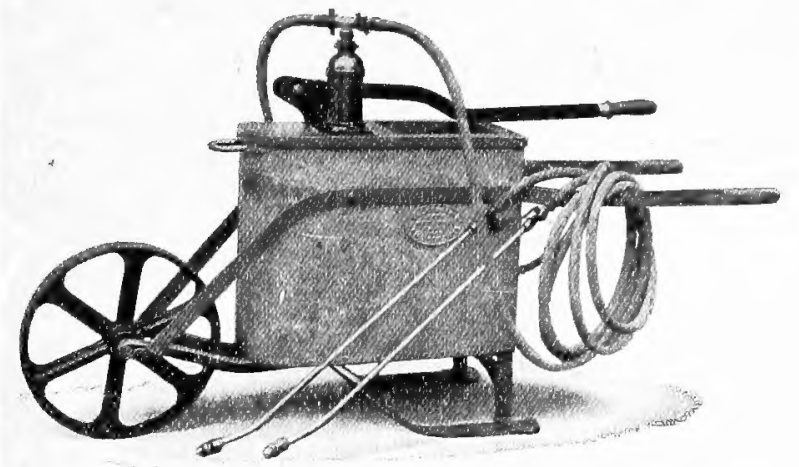

\author{
HAND, \\ HORSE POWER
}

\& POWER DRIVEN

MACHINES.

For Fruit, Hop,

Potatoes, also for
Limewashing

and Disinfecting

Purposes.

W. WEEKS \& SON, LTD., Engineers_MAIDSTONE. 
